\title{
Emerging Trends and Strategies for Industry 4.0: During and Beyond COVID-19
}

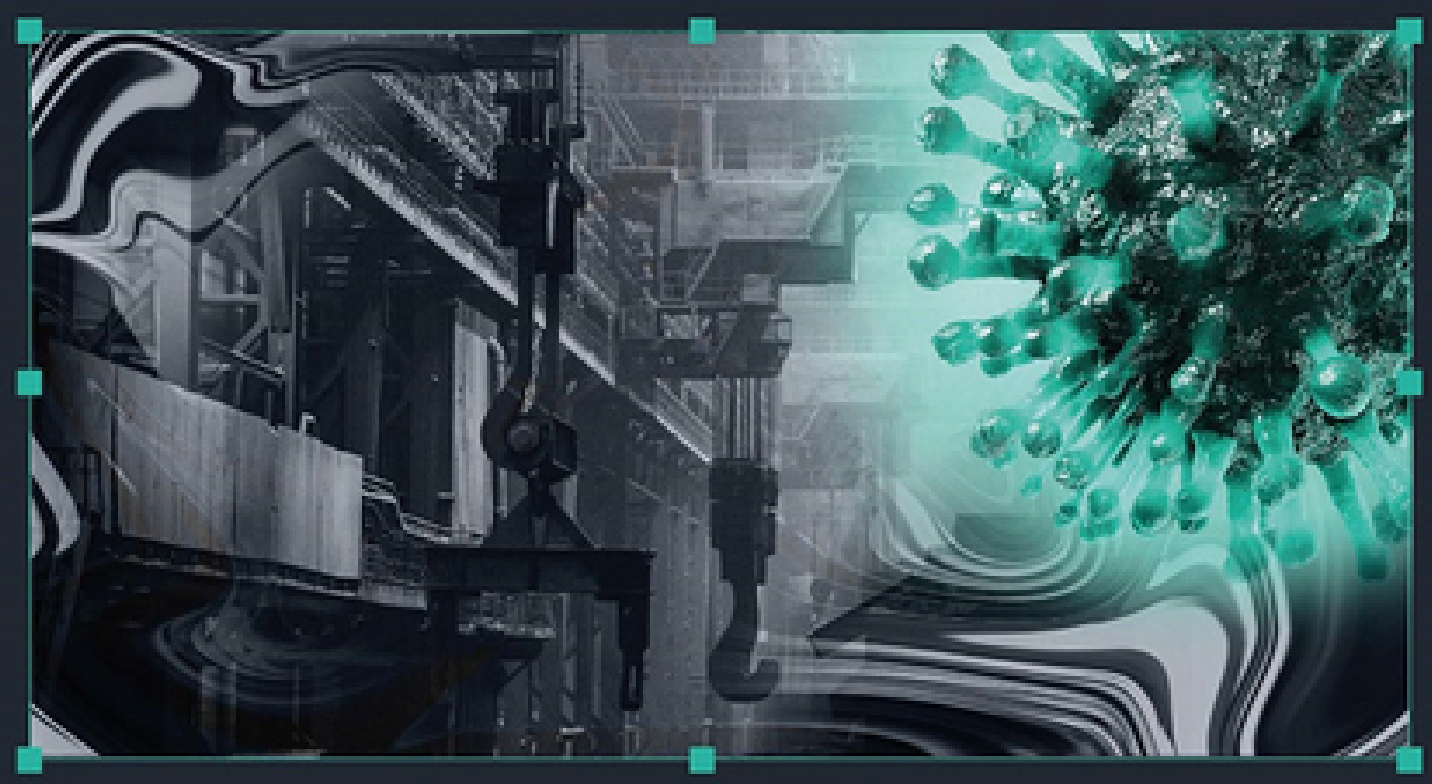

Bulent Akkaya

Kittisak Jermsittiparsert

Muhammad Abid Malik

Yesim Kocyigit 
EMERGING TRENDS AND STRATEGIES FOR INDUSTRY 4.0:

DURING AND BEYOND COVID-19 


\section{EMERGING TRENDS AND STRATEGIES FOR INDUSTRY 4.0: DURING AND BEYOND COVID-19}

EDITED BY

BULENT AKKAYA, Manisa Celal Bayar University, Turkey

KITTISAK JERMSITTIPARSERT, Henan University of Economics and Law, China MUHAMMAD ABID MALIK, Iqra University, Pakistan YESIM KOCYIGIT, Istanbul Gelisim University, Turkey

\section{Sciendo}

Germany

ISBN: 978-83-66675-38-4

https:/ / doi.org/10.2478/9788366675391 


\section{Preface}

"Emerging Trends and Strategies for Industry 4.0: During and Beyond Covid-19" is a thoughtprovoking book composed of original and previously unpublished chapters, which tries to shed light on the ways of the worldwide business environment.

The fourth stage of Industry Revolution called Industry 4.0 started a decade ago. Private companies and even public sector organizations have already been engaged in a digital transformation process. However, Covid-19 has played a role of a catalyst and increased the pace of that transformation. This unforeseeable challenge has resulted in a great uncertainty and ambiguity for both the organizations and governments. Existing theories, trends, strategies and practices are fast becoming obsolete in this new environment. As a result, there is a strong need for new theories, trends, strategies and practices to meet these challenges.

By presenting chapters from multidisciplinary perspectives, this book tries to bring into light some of the ways that are being used or suggested for this challenge. We expect this book to provide relevant theoretical frameworks, emerging trends and strategies, and latest empirical findings and business practices regarding the challenges and opportunities created by Covid19. It is hoped and expected that business practitioners as well as scholars will find this book useful to diffuse the fog, and suggest ways to thrive in this era of uncertainty.

We are deeply grateful for each author of the chapters for their scholarly contributions. We also thank the publishers for their support in this whole process.

Bulent Akkaya, Editor in chief

Kittisak Jermsittiparsert

Muhammad Abid Malik

Yesim Kocyigit 


\section{Acknowledgements}

I would like to express my gratitude to Sciendo Publishing and its publishing team for all their help and support.

I would also like to thank all the contributing authors and reviewers for their time and effort.

My gratitude also goes to my family for their encouragement and support.

Special thanks to Ms Magdalena Cal for helping with the process, Mr Yucel Sonmez for helping designing and Mr Tanapon Vipaporn for cover design. 
List of Contents

Preface

Acknowledgements

iii

List of Contents

List of Contributors

iv

$\mathrm{v}$

vi

About the Authors

vii

Chapter 1

Agility in the Organizational Context: Challenges in the 1st Year of COVID-19

Letiția Lucescu and Silvia Avasilcăi

\section{Chapter 2}

Analysis of the Problems of Social Services and Assistance During the Covid 19 Pandemic in Turkey

Canan Öykü Dönmez Kara and Gonca Gezer

\section{Chapter 3}

The Status of the Retail Sector During and After the Covid-19 Outbreak:

What Should Strategic Managers Do

Huseyin Guven, Emine Turkan Ayvaz Guven and Bulent Akkaya

\section{Chapter 4}

Work-Life Balance During COVID-19 Pandemic and Remote Work: A Systematic Literature Review

Helena Bulińska-Stangrecka, Anna Bagieńska and Y. Anuradha Iddagoda

\section{Chapter 5}

A Leader's Abilities to Manage Work-related Emotions during a Crisis

Donta S. Harper

Chapter 6

The Impact of Covid-19 On The Financial Contagion of Real Economy: A Sectoral Analysis

Deniz Erer and Elif Erer

\section{Chapter 7}

Covid-19 and the Educational Leadership and Management

Zafarullah Sahito and Gul Bahar Chachar

\section{Chapter 8}

Effect of Happy 8 Workplace and Corporate Social Responsibility on Success of Small and Medium Enterprises in Thailand during Covid-19

Kittisak Jermsittiparsert

\section{Chapter 9}

Usage of IT Interventions in the Containment of Covid-19 Spread

Ameema Mahroof 


\section{List of Contributors}

Bulent Akkaya, Manisa Celal Bayar University, Turkey

Kittisak Jermsittiparsert, Henan University of Economics and Law, China

Muhammad Abid Malik, Iqra University, Pakistan

Yesim Kocyigit, Istanbul Gelisim University, Turkey

Letiția Lucescu, Gheorghe Asachi Technical University of Iasi, Romania

Silvia Avasilcăi, Gheorghe Asachi" Technical University of Iasi, Romania

Canan Öykü Dönmez Kara, Çanakkale Onsekiz Mart University, Turkey

Gonca Gezer, Çanakkale Onsekiz Mart University, Turkey

Huseyin Guven, Karabağlar Guidance and Research Center, Turkey.

Emine Turkan Ayvaz Guven, Manisa Celal Bayar University, Turkey

Helena Bulińska-Stangrecka, Social Sciences at Warsaw University of Technology, Poland

Anna Bagieńska, Bialystok University of Technology, Poland

Y. Anuradha Iddagoda, University of Sri Jayewardenepura, Sri Lanka

Donta S. Harper, University of Washington, USA

Deniz Erer, Independent Researcher, Turkey

Elif Erer, Independent Researcher, Turkey

Zafarullah Sahito, Sukkur IBA University, Pakistan

Gul Bahar Chachar, Sukkur IBA University, Pakistan

Ameema Mahroof, University of the Punjab, Pakistan 


\section{About The Authors}

Bulent AKKAYA (PhD) is from Manisa Celal Bayar University, Manisa, Turkey. He received his Bachelor's degree in Teaching English Department in 2006 in Kocaeli University and received his master's degree in 2013 in Business Administration Department in Celal Bayar University. In 2018, he holds PhD in Business Administration Management with a specialization in Management from İzmir Katip Çelebi University. He has been working as Dr. Lecturer in the Department of Office Management-Executive Assistant of Manisa Celal Bayar University in Turkey. His research interests comprise networks and partnerships in diverse disciplines. He has been working on dynamic capabilities, agile leadership, industry 4.0 and quality of management in contemporary enterprises. He worked as a researcher in four projects and as an executive in a project. He published many articles and book chapters both in Turkish and English.

Kittisak Jermsittiparsert is a Full-Professor of Public Administration at MBA School, Henan University of Economics and Law, China. He currently also is an Adjunct Research Professor at Faculty of Humanities and Social Sciences \& Institute of Research and Development, Duy Tan University, Vietnam and the Secretary General of the Political Science Association of Kasetsart University, Thailand. He holds Ph.D. in Social Sciences (Political Science) from Kasetsart University, Thailand. His areas of expertise are Political Science, Public and Private Management, International Political Economy, and Social Research. Since 2012, he has published more than 370 Scopus/WoS indexed documents. Up to now, his H-index is 35 , total citation of his papers is more than 3400 times. He is an editorial board member of many international journals and conference proceedings and also regularly invited to deliver keynote speeches by various universities and societies.

Muhammad Abid Malik (Assistant Professor) is from Iqra University Pakistan. He did hisfirst masters in English literature from BZU, Pakistan. He did his second master and later $\mathrm{PhD}$ in Comparative Education from Beijing Normal University, China. His areas of interest in research are numerous and varied. They include comparative education, qualitative research method, leadership and management, shadow education, distance and online education, blended learning, gender issues, peace education, and higher education. He is also working on multiple books. He strongly believes in collaborative research and has been working with researchers from different parts of the world.

Yesim KOCYIGIT (Assistant Professor) is from Istanbul Gelisim University, Turkey. She graduated from Dumlupınar University, Faculty of Economics and Administrative Sciences, Department of Business Administration. Afterwards, she started to study for a Master's degree at Dumlupinar University, Institute of Social Sciences, Department of Management and Organisation. After graduating with a Master's degree in 2010, she was assigned as an Instructor to Dumlupınar University Hisarcık Vocational School. She started the Doctorate in 2013 and graduated from İzmir Kâtip Çelebi Çelebi University, Department of Business Administration in 2018. She has worked at İstanbul Gelişim Üniversitesi for three academic terms as an Assistant Professor. Her studies are in the fields of organisational behaviour, human resource management and strategic management.

Professor Silvia Avasilcăi (PhD) is a tenured university professor at "Gheorghe Asachi" Technical University of Iasi, Romania, Director of Department of Engineering and Management, and since 2010, a Ph.D. supervisor in "Engineering and Management" field of 
study. She gives her students and private companies clients unbiased and laser-clear advice on topics covering her main research interests that span along a continuum in Entrepreneurship, Innovation Management, Organisational Performance Management and Strategic Management. An internationally acclaimed scholar with more than 20 books published nationally and internationally, more than 80 articles in ISI WoS, over 70 articles in other IDB publications, Professor Silvia Avasilcăi has also chaired numerous EU research and consulting projects.

Letiția Carmen Lucescu is from "Gheorghe Asachi" Technical University of Iași, Romania. A Ph.D. student with an interest in agility as the capability that organizations use to reinvent themselves by continuously learning, dissolving their limits and making the unknown resources of energy and talent work in making their vision true. She served as an MBA Program tutor for Performant Management and Communication (Open University Business School, UK), is a founding member at Evolutiv Consultants, since 2004 is teaching management and communication skills at the National Institute of Magistrates and is an expert for EU Commission in innovation and research field. Letiția has published articles in Review of Management and Economic Engineering Journal and presented papers at international conferences.

Canan Öykü Dönmez Kara (PhD) graduated from Çanakkale Mili Piyango Anatolian High School in 1997. She completed her license in 2002 at Çanakkale Onsekiz Mart University, Department of Finance. She completed her master's degrees Çanakkale Onsekiz Mart University Institute of Social Sciences, Department of Finance in 2005 and Çanakkale Onsekiz Mart University Institute of Social Sciences, Department of Labor Economics and Industrial Relations in 2010. In 2015, she completed her doctorate education at Çanakkale Onsekiz Mart University, Institute of Social Sciences, Department of International Relations. She is currently working as a doctoral lecturer at Biga Faculty of Economics and Administrative Sciences, Department of Labor Economics and Industrial Relations. She works on migration, asylum and social policy. She is married with one child.

Gonca Gezer Aydın (Assistant Professor) graduated a bachelor's degree from Uludağ University, Faculty of Economics and Administnative Sciences, Labour Economics and Industrial Relations department, in 2009. In 2011, she completed her master degree in Uludağ University, Labour Economics and Industrial Relations Department. In the same year, she started her doctorate education in the same department and university. She started working as a research assistant at Çanakkale Onsekiz Mart University in 2012. She became a doctor in 2016. She was appointed as Assist. Prof. in 2018 and she still works at the same position.

Huseyin Guven (PhD), is a Teacher at the Karabağlar Guidance and Research Center, Turkey.He also worked as a lecturer at Manisa Celal Bayar University, Turkey. Her fields of teaching and resource are related to do Experiential Marketing, Sensory Marketing, Social Media Marketing and Digital Marketing. Dr. Guven holds her PhD in Marketings at Manisa Celal Bayar University (2019). Dr. Guven has articles published in various journals in Turkey and in abroad and also has participated in some projects and conferences. He is married and has two children. 
Emine Turkan Ayvaz Guven (PhD), is a Lecturer at the Department of Human Resources Management and vice manager of Ahmetli Vocational Higher School since 2019 at Manisa Celal Bayar University, Turkey. Her fields of teaching and resource are related to do economic growth, unemployment current account deficit, inflation, FDI and income desruption. Dr. Ayvaz Guven holds her PhD in Economics at Manisa Celal Bayar University (2016). Dr. Ayvaz Guven has published in various journals in Turkey and in abroad and also has participated in some projects and conferences. Lecturer Ayvaz Guven is reviewing for 1 international conference and 1 international journal in Economics.

Helena Bulińska-Stangrecka(PhD) is an Assistant Professor at Faculty of Administration and Social Sciences at Warsaw University of Technology. Her research focuses on the human resource management, knowledge management, trust, engagement and organizational culture.

Anna Bagieńska (PhD) is an Assistant Professor at Faculty of Engineering Management at Bialystok University of Technology in Poland. Her research interests include human resource management, knowledge management, corporate social responsibility and integrated reporting.

Y. Anuradha Iddagoda (PhD) is a Senior Lecturer from the Management Sciences Unit Applied Sciences Faculty in the University of Sri Jayewardenepura Sri Lanka. Her research focuses on Human Resource Management, employee engagement, personal character, green human resource management and green employee engagement.

Donta S. Harper (Professor) is a part-time professor and lecturer in the Criminal Justice program at the University of Washington. Donta received his bachelor's degree in Criminology in 1999 from the University of La Verne, California. His Master of Arts degree was in Counseling Psychology from Saint Martin's University, which he received in 2002 and his Doctorate in Education and Organizational Leadership from Argosy University was awarded to him in 2015. Donta is currently an executive in Criminal Justice in the United States. He has more than twenty-two years work experience in the criminal justice system. Of these, more than fifteen years have been served in an executive role. Donta has been extensively published in peer-reviewed journals, and his expertise ranges from emotional intelligence to emotion regulation and their intersection with leadership and leadership development. He has written several chapters in books and edited books that have been published under his name. The most recent of his edited books is Integration and Application of Business Graduate and Business Leader Competency-Models. Donta is a researcher whose study interests focus on managerial behavioral competencies. His other areas of study, as referenced, are emotional intelligence, emotion regulation, interpersonal emotion regulation, socialidentity theories, and leader identity development.

Elif Erer (Independent Researcher) was born in İzmir, in 1987. She holds a BA in Econometrics from Dokuz Eylul University, Turkey, in 2009, a Master's degree in Econometrics from Dokuz Eylul University in 2011 and a PhD in Economics from Ege University in 2018. Her PhD thesis is relating to public debt management in terms of micro and macro perspectives. She is an economist with technical skills on the econometric modelling of economy through time series 
models. Her current research agenda is focussed on using these skills to construct models of macroeconomic subjects such as inflation, growth, unemployment, exchange rate and financial markets. Her research areas include international capital movements, monetary policy, financial markets, financial instability and public finance. She participated in Ege University Scientific Research Project.

Deniz Erer (Independent Researcher) was born in İzmir, in 1987. She holds a BA in Econometrics from Dokuz Eylul University, Turkey, in 2009, a Master's degree in Econometrics from Dokuz Eylul University in 2011 and a PhD in Economics from Ege University in 2018. Her PhD thesis is relating to the determinants of carry trade activities and its effect on Turkey, BRICS, USA and England economies. She is an economist with technical skills on econometric modelling and applied econometrics. Her research areas include international capital movements, exchange rates, international financial markets and monetary policy. She participated in TUBITAK Project and Ege University Scientific Research Project.

Zafarullah Sahito (Associate Professor) is Postdoc and Ph.D. from the School of Applied Educational Science and Teacher Education, Philosophical Faculty, University of Eastern Finland, Joensuu. Dr. Sahito is currently working as a Head of Department and Associate Professor at the Department of Education, Sukkur IBA University, Sindh, Pakistan. Dr. Sahito has over 21 years of teaching, training, research and administrative experience at school and university level in Pakistan. He has published more than 22 research articles in reputed journals of the world. Currently, he is supervising more than 8 M.Phil dissertations on different topics related HRM, Educational Leadership and Management, and Quality Education. He is also working on different research articles in collaboration with different researcher around the globe, especially with research partners in Finland and Pakistan.

Gul Bahar Chachar (M.Phil in Education) is from Sukkur IBA University. He received his Bachelor's and M.Phil in Education from the Department of Education, Sukkur IBA University, Sindh, Pakistan. Mr. Chachar is currently working as a researcher at the same Department. He has more than 5 years teaching, research, and management experience at school and University level. He has presented 6 papers in different international conferences on different topics related to education. He is working on different research articles and book chapters in collaboration with different researchers at Pakistan Level. His interested areas are Educational Leadership and Management, Career counseling and planning, mathematics, science and language education, professional development and quality education.

Ameema Mahroof (Ph.D. Scholar, Program Manager) is from University of the Punjab and currently working as a Program Manager at Punjab Information Technology Board. She received his master degree in "Masters in Educational Research \& Assessment" from University of the Punjab in 2012 and received MPhil degree in 2016 from the same university. Doing a Ph.D. in Education from University of the Punjab. Her area of expertise are Educational Assessment and ICT in Education. From 2016 to 2018, she also worked as an Instructor of Education at Virtual University of Pakistan. 


\title{
Chapter 1
}

\section{Agility in the Organizational Context: Challenges in the $1^{\text {st }}$ Year of COVID-19}

\author{
Letiția Carmen Lucescu, Silvia Avasilcăi
}

\begin{abstract}
The year 2020, the 1st year of COVID-19, will most probably remain in the collective memory as a time flooded by uncertainty and doubled by the prominent need to unlearn the old practices.

Based upon a statistical analysis of words that are looked up in extremely high numbers in MerriamWebster online dictionary, the Word of the Year for 2020 is "pandemic", and regardless how pandemic has affected the workplaces, it is likely that the paradigm of thinking about work has shifted. During this span of time organizations and individuals are massively set to making trial runs and transform the way of approaching decision-making processes and the way of behaving in unconventional standpoints while lacking the well-established landmarks they used to compass strategic decisions.
\end{abstract}

COVID-19 has significantly changed the way we look at labor and its constituents, it has disrupted the way organizations used to run their businesses and, almost overnight, forced the adoption of otherwise latent trends.

At a macro level, the uncertainties, the general sentiment of insecurity and complexity fall in a rush and the provided solutions are temporary and do not address all business segments. As it seems that the only hope can emerge from the micro level, we aim to explore the way the organizations will manage to provide a sense of safety and confirmation to employees in order to reduce fear of unpredictable environment that will most probably become a competitive advantage on the market.

Therefore, at a more granular level, this chapter aims to contribute with a perspective of how these months of operating in survival mode have provided valuable insight into the way organizations and people can unequivocally move forward from this turbulence and position themselves to navigate the future disruptions that are bound to occur.

Keywords: Collective Resilience, Fluent Change, Dynamic Organizational System, Organizational Agility Enabler, Strategic Agility 


\section{INTRODUCTION}

The pandemic raises some relevant questions for both researchers and practitioners seeking adaptability, dynamism and stability in the organizational context as we no longer have the groundwork, we have previously tested to establish directions. In addition, the organizational culture and work climate are now imbalanced, and it is again, a capability at the micro level to stabilize them.

- What clear-cut capability substantiates itself to be a priority in a large-scale COVID- 19 crisis, so that the organizational agility $(\mathrm{OA})$ does not lose its expected impact on performance, or rather more appropriate, on survival? (Lucescu, Avasilcăi, 2020)

- What incapacities, scarce resources and other inefficiencies come to light during a crisis?

\section{BACKGROUND}

Scholars and practitioners together have not reached yet a straightforward conclusion regarding a specific, unquestionable feature that makes the current pandemic challenge unique. A lot of ink has been spilled looking for a definition for COVID-19 based on the similarities and differences from other crises.

If this slice of life registers itself as a "black swan"- type of manifestation (Taleb, 2018) we could make the most of the flag indicators we might have ignored so far, learn and come up with mature detection routines quickly and in collaboratively calibrated measures.

If it is just "a brutal shaking of the environment" (Christensen, 1997) we would find a way to steer the course until things would return to normal, although, much as it seems already, the virus might be a few years- long turmoil during which permanent changes could materialize.

Finally, if this circumstance is what Bennis and Nanus (1987) would call a habitual manifestation of the environment characterized by volatility, uncertainty, complexity and ambiguity (VUCA), the plans and strategies to be developed are not to be steadfast solid.

It is also possible that this crisis is something completely new, and hence it deserves its own identity to be shaped.

Be that as it may, the first year of COVID-19 crisis has a profile amorphously stamped by deep uncertainty. Organizations with agility attributes that document managing this period well might ground this denominator emerging from their anticipatory capabilities (Gladwell, 2008) and their continuous environmental monitoring routines (Worley, Williams, \& Edward, 2014). As for the way in which these routines have been applied by organizations or officials, deducting from the reactions they manifested, one could say that they were either applied correctly or they were simply ignored.

\section{COLLECTIVE RESILIENCE: CONTRIBUTING FACTOR OF AGILITY IN ORGANIZATIONAL CONTEXT}

An agile capability in organizational context will facilitate the development of another organizational capability, the one of collective resilience. In fact, both agility in organizational context and resilience are structured around a strong sense of clearly defined identity and purpose, as well as widely held organizational values and beliefs. Decision to start or investigate 
developing agility in an organizational context without investing in organizational resilience is risky, as it creates a general sense of fragility, an unsustainable exposure to turbulence and shock (McCann \& Lee, 2009). Interest in resilience, as an observable concept or phenomenon has emerged independently in various fields, such as the ecological field (Holling, 1973) or the psychological dimension for the future of work (Garmezy, 1971) and was influenced by the theory of general systems (Kristof, Verschraegen, Valentinov, \& Gruezmacher, 2019).

Broadly defined, resilience is the ability to adapt in a sustainable and resolute way during confusing, inconsistent changes that jeopardize the functioning, development or existence of a dynamic system.

The concept can be applied to systems (not just living ones) at different levels of interaction, such as a microorganism, an individual, a family, a security system or the global climate, and has its roots in the Latin verb resilire (to return). Resilience has been defined as achieving positive results despite the challenging or threatening circumstances (Masten, 2001), coping with traumatic experiences successfully and avoiding negative risk-related pathways (Garmezy,1971). It can be understood as the ability of people to regard stress to an acceptable degree, to cope in a healthy and generative way with the daily challenges and threats or to recover from disappointments and even traumas, to develop clear and realistic goals and ambitions and to feel comfortable to interact with other people (Kristof et al., 2019). Researchers have been interested in understanding why some systems do not manifest the negative effects as a result of the negative events experienced, but on the contrary, they learn to cope with them and have a normal development. Several waves of research cover collective resilience, starting with scientists who seek to understand and prevent the decay of psychological health (Masten, 2001), with research focused on detecting processes and regulatory systems that took into account the protection factors associated with resilience. A common conclusion came to life, that the analysis of a single risk indicator does not reflect the reality of being exposed to adversity (Masten, 2001). In the modern form of approach, resilience is the result of "a series of individual characteristics, such as cognitive abilities, temperament compliance, good self-regulation, self-efficiency and a positive outlook" (Yates, 2003).

Resilience can also be interpreted, explained and epitomized by surveying and scaling contextual factors that manifest themselves in the dynamic of a process (Egeland, 2007).

In organizations, resilience is the ability to recover, not only after a shock, but "after a series of intensely difficult events and is a feature of successful organizations" (Setili, 2014). In the traditional approach to change, experts propose successive steps, with a constant focus on increasing people's resilience. In the context of volatility, uncertainty, complexity and ambiguity, the organization is subject to a process of collective, continuous and fluent adaptation, following a clear goal path, ample enough to inspire and call up the entire organizational population. In the face of uncertainty, organizations fearfully look to the future, and that is for a good reason, as it promises to be difficult and burdensome from a perspective that is multiplied by each individual.

As for the collective resilience dimension, that may be accomplished from a systemic perspective of the organization. While the saying "no one is left behind" has been heard in many social contexts, each public appeal presented both hope and a level of anxiety and, at micro level, each leader gathered the teams to plan the sustainability of their companies, together. 


\section{THREE POSSIBLE WORKING SCENARIOS TO START INVESTIGATE RESILIENCE IN AGILE ORGANIZATIONS}

A conceptual model of this hypothesis would incorporate three axes from which the stressors originate from.

Here are three possible working scenarios to start investigating resilience playing the role of a widespread capability during the continuous process of Sensing-Decision making- and Response as an enabler of strategic agility in the organizational context (Lucescu, Avasilcăi, 2020):

1. The individual level- the individual in relationship with him/herself.

In what way I can operate with myself, as an individual. How I can manage my emotions, how I can reconstruct my emotional vocabulary, how I relapse and how I can apply proper techniques to adapt myself to the new environment.

2. The team level- the individual in relationship with the team:

How I can take care of own relationships with others. The way in which these relationships are tested in remote working conditions and the uncertainties that will follow.

3. The organizational system level- that is the individual in relationship with the organizational system. In what way the operations carried out by the individual have an impact upon the organization, as a whole. What exactly can an individual do to work in the new conditions.

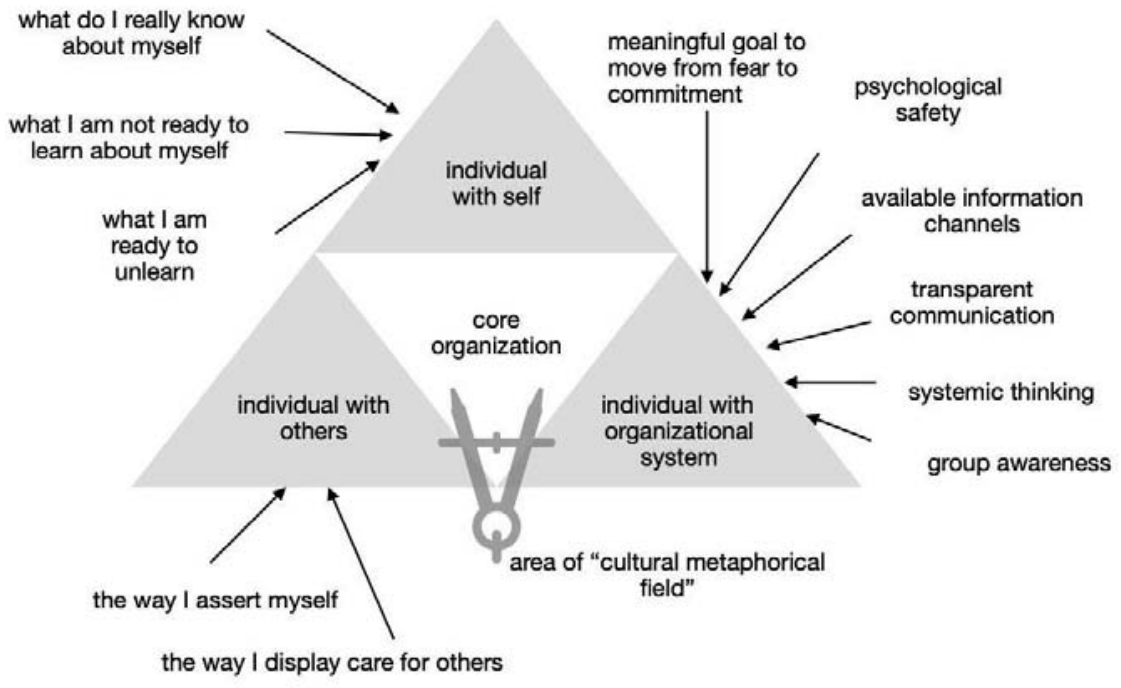

Figure 1. Resilience framework 
In this chapter we propose the dynamic that manifests at the system level, with an aim to explore the practicability of adding the proficiency of collective resilience to those that contribute to enhancing agility in organizational contexts:

- Does the organization have such a clear, meaningful goal for people so that they can move potency from fear and proceed towards the goal on the axis of fortitude, motivation and commitment?

- Do employees have a sense of psychological safety (Edmondson, 2019)? Do they allow themselves to make mistakes especially because in the end they do not know what will happen next? Fostering a cultural environment that holds space for sharing trial- anderror stories, failures, best practices, insightful examples of sound challenges, candid feelings and vulnerabilities would lead to creating a safe space for others to dare and do the same. It reminds everyone that collective wisdom and transversal collaboration from a psychological safety mind- model get next to a much better chance to achieve a bigger positive impact.

- Is the organization creating context for contribution channels? If the organization hits a dangerous season, does everyone know where the resources are that can help rebuild it to save them all?

- Do stakeholders communicate transparently? Do all the teams know what decisions are going to be made, what plans does the company envisage and do the teams know how to access the contribution channels? Do employees think systemically? How do they tackle new issues so as to approach complex processes and to be aware of what the groups think? A simulation of organizational adaptation models shows that decentralized ones modulate more easily in the face of turbulence in a simple environment, and adapt quickly, the relationship with the system parameter being approached more effectively by anticipation, rather than by resilience. (McCann et al., 2009)

Resilience skills are related to the ability to manifest, spontaneously and naturally:

the 7 abilities of resilience

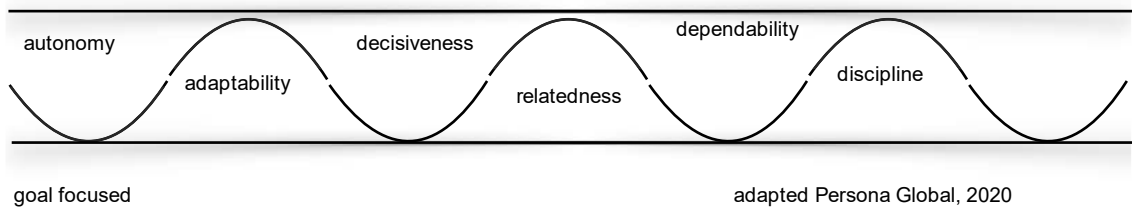

Figure 2. Resilience model from a behaviour perspective

- Abiding focus on goal implies finding meaning and significance even in intervals of uncertainty and deadlock and traverses the triangle:

$>$ at individual level: in what proportion people are clear about both their options to individually contribute to the purpose of the organization and to what bring value for them, as persons, 
$>$ at team level: clarity in how people contribute to the core vision of the organization, giving up aspects that are not vital (pandemic is an opportunity for simplification, for finding redundant, obsolete or bureaucratic channels of practices and re-process them),

$>$ at organizational system level: clarity in how the goal is manifested (leadership must be aligned with the formal stated goal).

- Autonomy: maintaining self-confidence and self-leadership, despite challenges.

$>$ at individual level: I can govern, accomplish and perform my roles and activities both in the organization and in my personal, private life,

$>$ at team level: strong belief that together we can effectuate and carry out our roles,

$>$ at organizational system level: we can operate and take care of business, focusing on vital resources, looking for solutions to key problems.

The pandemic focuses on the dynamics of the tandem of individual autonomy and organizational autonomy through the mechanisms of understanding core modus operandi and focus on the key and essential issues of the organization. Working from home has de-bureaucratized supervision and increased flexibility in decision-making, which is why the need to make it sustainable is paramount.

- Adaptability:

$>$ at individual level: I identify the level control I can administer over personal activities and life. I create or adapt new ways to achieve my goals without compromising my values.

$>$ at team level: team members identify what level of control the team meets and focus on new ways or adapt them to achieve goals without compromising integrity values,

$>$ at organizational system level: people identify the level of control the organization achieves and focus on new ways or adapt them to achieve goals, without compromising our values-integrity.

- Decisiveness

$>$-waiting for the leader to make decisions with care for people, perseverance to work in different situations until finding a viable solution, concert of energies to achieve results, each challenge being used as a learning opportunity (Avasilcăi, Huțu, 2012).

$>$ at individual level: I am persevering, I work collaboratively to find solutions in my activity and in my life. I am objective in analysing the situation so that I can make different decisions, learning from each challenge.

$>$ at team level: team members are persevering, they work collaboratively, they take care of people,

$>$ at organizational system level: people create and produce a persevering way of working, managers analyse objectively and engage difficult decisions while taking care of people.

- Relatedness

$>$ the ability to stay connected; solidarity; creating, maintaining a support network in personal and professional life.

$>$ at individual level: I maintain strong working relationships, based on empathy, trust; in my personal life I create supportive relationships in which I can share ideas, concerns and feelings. I maintain a high level of social and self-awareness.

$>$ at team level: we create a culture-support team with rules, giving priority to collaboration, trust in work, empathy and lack of prejudice,

$>$ at organizational system level: we create a support network at all levels with a focus on collaboration that does not criticize and trusts to achieve its goals.

- Dependability 
$>$ the ability is born in an environment where anxiety is validated as emotion and acts towards maintaining relationships by identifying the unaltered aspects of challenges, for which, gratefully and proactively, opportunities are sought to achieve a positive result.

$>$ at individual level: strive to maintain an attitude that pursues a positive attribute in any situation; I look for unaltered aspects of challenges and I am grateful for what I have in my life,

$>$ at team level: we work as a team to identify and promote positive aspects and celebrate successes, no matter how small. Team rules include looking for opportunities and making decisions to make them happen,

$>$ at organizational system level: we promote the belief that there will be a good result in the future. We identify and promote those aspects of organizational life that are positive and that allow people to focus on what is essential.

- Discipline

$>$ make sure people focus on a mentally healthy state, provide support to access reenergizing resources, and cultivate a calm, composed and scrutinizing culture.

Similar to agility in the organizational context, resilience is not an aspiration and is not intangible, it is a mental pattern and a set of measurable abilities. An organizational culture that recognizes the need to train the resilient paradigm, plans communication projects in which people feel listened to and supported to, will ultimately create a calm climate under pressure.

Neither agility in an organizational context nor resilience, taken separately, can ensure the viability of an organization in the midst of turbulence and shocks of unprecedented complexity.

In terms of ambidextrous ability to scan, quickly understand and decide market responses that lead to new directions from which to thrive despite the risks, resilient agility, however, becomes a massive contributing factor to the development of agile organizations that deserves to be addressed over time.

\section{FUTURE RESEARCH DIRECTIONS: THREE NEW ANGLES COVID-19 REVEALED FOR DEVELOPING AGILITY IN ORGANIZATIONAL CONTEXT}

Pre-pandemic, many organizations were busy innovating in pursue for competitive advantages and successfully reach new market quota while strategic scenario to respond to an impactful VUCA event were rather out of sight. The business environment was robust, the market challenged and praised efficiency, and executives used to regard risk as mere statistics, despite systemic interdependencies. Instead of identifying the potential risks of VUCA and organizational fragility, many organizations have exploited cash flow and overlooked holistic investment in sharpening soft skills and extra capabilities.

Managing VUCA contexts involves both accepting "inherent contradictions and embracing the paradoxes of organizational life" (Lewis, Andriopoulos, \& Smith, 2014). The disputed point is, as Lewis et al. point out, that the executive's immediate typical inclination may be to suppress this very perceived paradox, by isolating one dissonant point of view and promoting another as "accepted wisdom." By scrutinizing this tendency to respond and achieving to change the narrative at the management level might hinder the trap of getting captive in a series of limiting assumptions, which inhibit innovation, creativity, involvement and the desire to collaborate, leaving the organization stuck and impossible to learn and adapt.

In addition, many managers tend to avoid engaging in pre-mortem discussions (Klein, 2007). Ultimately, it is fear that prevents them from exploring failure scenarios and possibilities for 
extreme risk. "That will never happen," is something that, in the context of VUCA, is not a statement to be trusted.

Agility in organizational context seems to better equip people with certain coping skills when facing volatility, as their effectiveness for scanning the environment and detecting small changes train them to respond promptly when yesterday's improbable risk reaches their terrain.

Running into the phenomenon of the COVID-19 world, organizations are rethinking all the tools for managing unprecedented tasks and threats: how to protect the health of employees and customers, how to redistribute talent potential, how to organize work remotely, how to evaluate results, how to relate to the team, how to ensure the technological infrastructure, how to ensure the security of information flow, how to support supply chains, how to contribute to the humanitarian effort, how to decide the redistribution of labour, the employment plan, what are the new dismissal criteria, how to plan reopening operations due to various uncertainties related to legislation and sanitary instructions and regulations.

Taking these instances into account, the COVID-19 crisis has revealed at least three implications for research and development of agility in the organizational context and sustainability in volatile, uncertain, complex and ambiguous environments.

- How to individualize the COVID-19 crisis and the responses circulating globally in conditions that are unclear, not validated, and often contradictory.

- Proclaiming an organization as agile, does not turn it into one. Despite the rhetoric and promotional or study materials, too many organizations made evident that they did not have the optimal capacity to respond.

- The COVID-19 pandemic reveals financial, social and structural inequalities that give carte blanche to unethical positions and community polarizations.

Social media arenas abound with examples of organizations that act quickly and easily to respond to acute needs. The rapid response of the medical community and the spectacular reposition to work remote/from home have been impressive. Still, in an OA frame of reference, we need to make a clear-cut distinction between what is a "brilliant improvisation" (Pal, 2005) and the ability to repeat the same operations in the same way and even better and in a viable, sustainable way. The difference between operating agile out of necessity or applying a methodology by the book and actually being agile is conditioned by the well-known ability to learn with intent, continuously, at all organizational levels, together with other two capacities that enable the organizational agility: situational awareness and a sense of purpose. (Joiner, Josephs, 2007).

From the experiences gained in the occupational learning industry, we can state that organizations often encourage this "brilliant improvisation" on intentional learning, projecting extensive culture changes following learning bites (Izza, Imah, Vincent, \& Lounis, 2008) of opportunistic type and without ensuring continuity or supporting the development of skills, through "push learning" techniques through which employees are sent to training sessions with a duration of several days. While there are cases when trainees admit that the information is retained superficially, only in small proportion and for just a limited time, the trap of interpreting this kind of information as a competence (Izza et al., 2008), only favours maintaining the status quo, deepening psychological insecurity, demotivation and instrumentation of ego-dictated authoritative power.

Instead, pillars of agility in organizational context recognize, reward and nurture learning instead of blacklisting failure, while executives make fast decisions to generate new channels of information. This does not mean that agility infused organizations are perfect - some stumbled severely during the crisis - but their agility supports their ability to return to the market and make 
changes in the three organizational pillars consisting of Strategy-People-Systems (Lucescu, Avasilcăi, 2020).

\section{CONCLUSION:}

The subtle meaning of the "fluent change" metaphor could possibly guide the development of the agile organization by mirroring the case of language fluency, that begins with learning words, conjugations and then moving towards an increasingly complex syntax. Due to the fact that the methods of obtaining results change over time, the focus on financial results also changes, and sustainability does not exist without agility (Lichtenstein, 2006).

The role of management would be to create channels that allows users to access them, to guide information flows, as well as to monitor and analyse the results and lessons learned (Ibarra, 2018). This is another paradigm of work. Following the lessons learned in the COVID-19 crisis we can fortunately start an era in which partnership, co-creation, collaboration, solidarity and care for the well-being of people to become the norms of business behaviour.

Life goes on and we cannot solve these new arising issues, like creating a sense of safety, courage and resilience with old methods. That is why, in the new reality in which we are striving to develop skills to face ambiguity and lack of predictability, agility might imply an update to the "management genome" and learn to become resilient in a world of unprecedented challenges and light-speed change. 


\section{REFERENCES}

Avasilcăi, S., Huțu, A.C. (2012). Competențe antreprenoriale. Iași: Performantica.

Bennet, N., \& Lemoine, J. G. (2014, January- February). What VUCA Really Means for You. Harvard Business Review.

Christensen, C. (1997). The Innovator's Dilemma- when new technologies cause great firms to fail. Boston, Massachusetts: Harvard Business School Press.

Egeland, B. (2007, volume 34). Understanding developmental processes and mechanisms of resilience. Multi-level dynamics in developmental psychology; pathways to the future.

Edmondson, A. C. (2019). The Fearless Organization: Creating Psychological Safety in the Workplace for Learning, Innovation and Growth. New Jersey: John Wiley \& Sons,

Inc.

Garmezy, N. (1971). Reflections on the Future. Psychology, Science and Human Affairs, 109-124.

Gladwell, M. (2008). The Tipping Point: How Litte Things Can Make a Big Difference. New York: Hachette Book Group.

Holling, C. (1973, November). Resilience and Stability of Ecological Systems. Annual Review of Ecology and Systematics.

Ibarra, H. (2018, October 9). What Will Leadership Look Like In The Age of AI? . TEDx London Business School. WIRED Smarter.

Izza, S., Imah, R., Vincent, L., \& Lounis, Y. (2008). An Approach for the Evaluation of the Agility in the Context of Enterprise Interoperability. The 4th International Conference on Interoperability for Enterprise Software and Applications. Berlin.

Joiner, B., Josephs, S. (2007). Leadership Agility: Five Levels of Mastery for Anticipating and Initiating Change. San Francisco: Josey- Bass, A Wiley Imprint.

Kristof, V., Verschraegen, G., Valentinov, V., \& Gruezmacher, M. (2019, April). The Social, the Ecological and the Adaptive. Von Bertalanffy's general systems theory and the adaptive governance of social-ecological systems. Systems Research and Behavioral Science.

Lewis, M., Andriopoulos, C., \& Smith, W. K. (2014). Paradoxical Leadership to Enable Strategic Agility. California Management Review, pp. 58-77.

Lichtenstein, B. B.-B. (2006). Complexity leadership theory: an interactive perspective on leading in complex adaptive ssytems. ( $r . f$. https://www.researchgate.net/publication/259828753.

Lucescu, L. C., \& Avasilcăi, S. (2019, March). Research regarding the concept of agility in organizational context- PhD research report. Iasi: "Gh. Asachi" Technical University Iasi.

Lucescu, L. C., \& Avasilcăi, S. (2020, March). Strategy, People, Systems- Pillars of Organizational Agility. Review of Management and Economic Engineering, pp. ISSN: 1583-624X, Volume 19, 221-234.

Lucescu, L. C., \& Avasilcăi, S. (2020, September). Issues, Common Errors and Barriers to the Development of Organizational Agility. Paper presented at the 7th International 
Management Conference, "Management Challenges within Globalization", Special Edition in Memoriam Professor Ioan Abrudan. Cluj Napoca.

Masten, A. (2001, March). Ordinary Magic: Resilience Process in Development. American Psychologist.

McCann, J., \& Lee, J. (2009, January). Building Agility, Resilience and Performance in Turbulent Environments. People EStrategy.

Pal, N. (2005). The Agile Enterprise, Reinventing your Organization for Success in an On-Demand World. Smeal College of Business, Springer Science., p. .

Setili, A. (2014). The Agility Advantage: How to identify and act on opportunities in a fast changing world. Jossey Bass, a Wiley Brand.

Taleb, N. (2018). Lebăda Neagră. București: Curtea Veche.

Worley, W. C., Williams, T. D., \& Edward, L. E. (2014). The Agility Factor: Building adaptable Organizations for Superior Performance. Josey Bass, a Worley Brand.

Yates, T. M. (2003). Rethinking Resilience: a developmental process perspective. Cambridge University Press. Resilience and vulnerability, 243-266. 


\title{
Chapter 2
}

\section{Analysis of the Problems of Social Services and Assistance During the Covid 19 Pandemic in Turkey}

\author{
Canan Öykü Dönmez Kara, Gonca Gezer Aydın
}

\begin{abstract}
The social welfare state can be defined as the state that provides social aid and services to the disadvantaged groups of the society and creates resources for this budget. Disadvantaged community members should also have access to social opportunities enough to live humanely, be protected against social risks, and benefit from the state's opportunities in the context of the principle of equality. In particular, the Covid-19 Pandemic has shown how vulnerable disadvantaged groups are to social risks worldwide. During the pandemic, many workplaces were closed, people lost their jobs, elder and patient citizens were imprisoned in their homes due to curfews. It was observed that states were unprepared for extraordinary situations such as pandemics. The pandemic also demonstrated the importance of social services and assistance to be offered to disadvantaged groups by the state in case of disasters that may affect the whole world. In this context, the purpose of the research is to reveal the problems encountered in managing social assistance and services for disadvantaged groups during the Covid-19 Pandemic process in Turkey and developing solutions for them. The research covers the problems encountered in the management of social services and assistance provided by Turkey during the Covid-19 process, and other countries constitute the limits of the study. The research was designed as qualitative research, and the data were collected by the document analysis method. News and columns on the management of social services and assistance during the Covid-19 Pandemic from national newspapers and the internet that are pro-government and opposed to the government have been collected. The collected data were subjected to content analysis using the MAXQDA 20 Program, and the findings were evaluated through figures. As a result, it has been understood that the delivery of social services and assistance provided by the state to the disadvantaged groups caused delays and disruptions due to the high demand, and financial aid should be increased.
\end{abstract}

Keywords: Covid 19, Social Service, Social Assistance, Printed Press, Turkey. 


\section{INTRODUCTION}

The Covid-19 pandemic, which emerged in Wuhan, China, towards the end of 2019, affected the whole world in a short time and spread to almost every country in the world. The epidemic caused $61,397,419$ people to become infected and 1,439,058 total death as of 27 November 2020 (Worldometers 2020). As known, many pandemics have occurred at various times throughout human history. However, the Covid-19 pandemic is considered the most serious pandemic in the world after the Spanish flu in terms of public health and global effects (Börke Tunalı, 2020: 26).

The impact of the epidemic not only threatened the health and lives of people but also caused countries to face a major crisis in social and economic terms. As a matter of fact, some economists claim that with the epidemic, the world is facing the most significant threat of crisis since the 1929 economic crisis. From a more optimistic point of view, it is stated that the epidemic will have similar consequences to the 2008 global financial crisis (Ustaoğlu, 2020:36). According to the United Nations report, the epidemic's negative impact is much more than these estimates. The United Nations (UN) predicts that the cost of the epidemic to the world economy will be around 8.1 trillion dollars (Demirbaş ve İncekara, 200: 54).

The biggest reason the economy has come to a halt with the epidemic is that people's health is seriously at risk. In order to prevent the spread of the epidemic, governments had to suspend economic activities and take a series of measures. These measures include the cessation of production in many sectors, the restriction of activities mainly in the service sector, the interruption of international trade, travel restrictions, online education activities, and the spread of home-office work in many sectors. As a result of these measures, the welfare level and economic activities were significantly affected (Arslan ve Bayar, 2020: 91-92).

In the World Bank's "Projected Poverty Impacts of Covid-19" report, it is estimated that the Covid-19 Pandemic will force 88 to 115 million people worldwide in 2020 into extreme poverty, where they will have to live on an income of fewer than 1.90 dollars a day. Besides, the number of poor people who earn less than $\$ 3.20$ a day has more than doubled between April and October 2020. This number, which was calculated as 125 million in April, increased to 257 million in October (World Bank, 2020).

In order to reduce the economic and social effects of the Covid-19 crisis, it is seen that the funding allocated to social assistance services and social protection has been increased in many countries. Countries with an effective and robust social protection system can protect their citizens better against the economic and social risks they face. Developing countries have been insufficient to produce effective and comprehensive policies with temporary and short-term measures.

As a matter of fact, the International Labor Organization (ILO), in its report titled "Financing Deficit in Social Protection: Global Forecasts beyond the Covid-19 Crisis and Strategies for Developing Countries" draws attention to the insufficient social expenditures and that countries should allocate more resources for these expenditures. According to the ILO, since the Covid-19 global pandemic started, developing countries' social protection financing deficit has increased by about $30 \%$. It is stated that the 
countries in question need to invest approximately USD 1.2 trillion to close this deficit, which corresponds to an average of 3.8 of their GDP (ILO, 2020).

Effects created by the Covid-19 pandemic has deeply affected Turkey as well as the rest of the world. With the appearance of the first cases in March of 2020 in Turkey, various measures have been taken to protect public health and mitigate the economic impact of the pandemic. In addition to the measures to compensate workers and employers' income losses, various aids and supports have been provided within the scope of social security systems and public social security expenditures. The measures taken caused severe public debate in terms of scope and effectiveness. The insufficiency of the support provided and the inefficient use of resources have brought criticism that society is left to its fate. In this context, it was aimed to examine the effectiveness of social assistance and services within the scope of public social security expenses made by the government during the Covid19 pandemic.

Firstly, the subject's theoretical dimensions were mentioned in the study; the conceptual dimension of social policy, social assistance, and services have been discussed. Besides, the literature on economic and social measures taken during the Covid-19 pandemic process was examined. The second part of the study is the field research. Within the field study's scope, the national printed press for social assistance and services was examined, and problems related to the implementation of social assistance and services were tried to be revealed.

\section{CONCEPTUAL FRAME}

Social policy is a set of activities aimed at meeting the needs of all members of society. While it is defined in a narrow sense as measures aimed at protecting workers against the dangers and misery created by industrialization and urbanization, its scope has expanded over time. In a broad sense, social policy includes activities that eliminate the differences and struggles between all classes and groups in society (Şenkal, 2011: 26). Social policy is a tool for achieving social equality and justice (Koray, 2008: 31-37).

According to Spicker (2014: 4-5), social policy includes social services and welfare state works. While dealing with the formation of policies needed in the society in terms of ensuring social welfare in general, it also deals with solving problems in more specific areas, including health, housing, education, social services, poverty, old age, disabled people, and family policies (Kleinman, 2006: 162). The social policy establishes a legal basis through its practices, contributing to the capital growth process, and providing social services that help establish reconciliation between the population and benefit society (Şenkal, 2011: 148).

In the most general sense, the social state concept is the state that has the authority to directly or indirectly intervene in economic and social life (Ayman Güler, 2006: 31). The social state aims to ensure the peace and welfare of society. However, the word "social" in the social state concept does not have the same meaning as the word "social." The concept of social in the social state cannot be limited to the idea of "help" to solve the problems of the groups whose existence is in danger. The social state is not a "social aid state," nor is it a "social policy state." The social state is a state born out of the contradiction between traditional statism and the industrial age's social life (Gören, 1997: 118-120). The social 
state links the protection of human dignity to the provision of social justice. In order to achieve this, the state's intervention in the social field has been legitimized when deemed necessary (Bulut, 2003: 174).

Social state has evolved through three phases: social assistance services, social security services, and social state. State assistance to sections of the population who, for various reasons, are deprived of self-care and development opportunities is considered within the scope of social assistance services. This stage occurred with the rise of capitalism and the dissolution of feudalism in modern Western societies. As a result of the abolition of feudalism, institutions such as large family structure, local communities, and church organization that took care of young, old, sick, disabled, and poor groups in society disappeared (Ayman Güler, 2006: 30-31). The working class was organized as a result of the expansion of industrialization, the intensification of urbanization, and the strengthening of the bourgeoisie with capitalist development during the 18th and 19th centuries, and the responsibility of the employer and the state came to the agenda for providing social security to the workers (Sallan Gül, 2000: 54). With the first applications in Germany in the last quarter of the 19th century, the accident, health, and pension insurance systems started to develop and spread between 1875 and 1925 (Ayman Güler, 2006: 31). The laws adopted in this context laid the foundations of the modern social security system for employees (Sallan Gül, 2000: 55).

The social state phase emerged with Statist or Keynesian policies developed after the World Economic Crisis of 1929 and became widespread after the Second World War with the social welfare policies implemented in Europe. The developed capitalist countries of the time were defined as the social welfare state and the less developed capitalist countries as the social state. While the social state financed public services through taxation, it also intervened in the market through direct participation in production and price controls. In this context, the rights that everyone can have equally in the social state are determined as education, health, housing, and employment rights, and efforts have been made to provide them to everyone at a minimum level (Yanik ve Kara, 2014: 13; Koray, 2005: 95).

The social state has to develop economic policies to provide the social policy areas to all society segments at a minimum level. Simultaneously, while implementing social policies, the social state uses tax and fiscal policies to create resources and correct income distribution inequalities; employment policies to prevent unemployment; social security, social assistance, and income transfers to diminish social injustice (Koray, 2005: 95-96).

Social assistance is the provision of financial or non-financial assistance to citizens in need (Taşc1, 2008: 129). Social assistance includes the practices that protect citizens who are outside the social security system (İpek, 2015: 88). In this context, social assistance includes a whole set of activities covering various fields such as health services, social support, education, employment, housing and aimed at protecting needy citizens through family and relatives, charitable and religious institutions (Y1lmaz ve Diğerleri, 2018: 600).

Social services are activities organized to facilitate individuals to live in harmony with each other and their environment. These activities include helping individuals, groups, and communities reach the highest level of well-being within the means of social, spiritual, and physical aspects. Social services are carried out by public, semi-public, and partly voluntary organizations. Contribution to financing is not required to benefit from the services. The particular situation of the protected person is taken into consideration in the execution of social services. In this context, the administration undertakes the 
authority to determine the citizens who will benefit from social services and monitor the services (Dilik, 1980: 73, 76-77).

The reactions of states to social, political, and economic problems have shaped different social state understandings and social welfare models. Within the structure of welfare models, regulations have been made to increase the state's responsibilities in education, health, full employment, and social welfare planning stages. After the Second World War, the legal regulations carried out under the leadership of England, France and Germany made the state responsible by establishing the understanding that social policy services are under the responsibility of the state. This situation led to an increase in the expectations of the state (Ersöz, 2005: 769).

There are four different social welfare models shaped in Europe. The first of the models is the Scandinavian Model. In this model, it is argued that the social benefit is the same for everyone. The second model is the Beveridge Model, which argues that the state is responsible for social problems and should have a social management approach to solve these problems. The third model, Bismarck/corporatist/continental model, has adopted the understanding of offering social benefits only to those found in the labor field. Finally, the Southern European Model (Cooperation Model) suggests that social responsibilities should be fulfilled within the family or among individuals close to the family (Şenkal ve Sariipek, 2007: 156).

In addition to all these welfare models, hybrid welfare models are also mentioned. Turkey's social welfare model is similar to the Bismarck model due to the employmentbased social insurance mechanism; it is similar to the Southern European Model in terms of sharing the social risks by the family and close environment where the social security system is lacking. The Catholic Church in Europe and practices such as alms and handouts, which are the duties of Islam in Turkey, meet some of the social services and aids (Dönmez Kara, 2020: 254; Özmen, 2017: 379).

Social assistance in Turkey has been described as a constitutional right, covering the sectors in need of society. The second article of the Constitution points out that the state is a social state, and there are regulations in various articles of the constitution. Article 5 of the Constitution includes the improvement of the material and spiritual assets of individuals, and the 60th article states that everyone has the right to social security, and the 61st article includes the protection of the victims of war, their families, the disadvantaged part of the society, such as the disabled and the elderly.

In Turkey, social services and assistance are carried out by the central government, local government, non-governmental organizations (associations and foundations), and the private sector. In local administrations, municipalities, special provincial administrations, and villages are important actors of regulations. Social services and assistance regulated by the public in Turkey are carried out within the scope of certain institutions or legal restrictions. These are social aids under the General Directorate of Social Assistance and Solidarity, financial and cash aids of the Social Services and Child Protection Agency, green card and pension fund aids, and social assistance provided by the Directorate General of Foundations (Zengin ve Diğerleri, 2012: 136-137; Taşc1, 2008: 131). The private sector plays a vital role in providing services for disadvantaged groups. The private sector offers various services to disadvantaged groups of society such as nursing homes for the elderly, nurseries and children's clubs for children, special education and rehabilitation centers for people with special education needs, aids, and education for disabled individuals (Çetin, 2014: 72). 
Social assistance and services have an essential function in compensating for increases in expenses and income cuts that occur in extraordinary situations such as economic crises and natural disasters. In this context, the Covid-19 pandemic once again reveals the importance of social state and social assistance and services due to the crisis conditions emerging all over the world. In many studies dealing with the economic and social problems caused by the pandemic, it is discussed that social spending and the role of the social state should be addressed again.

Islam and others (2020:389) have examined the government's measures to combat the Covid-19 outbreak in Bangladesh. The Bangladesh government announced a few financial packages worth 11.90 billion dollars, but the study emphasized that these aid packages were insufficient, and the government had to develop other strategies.

Dafuleya $(2020: 251,265)$ examined the social assistance provided in South Africa during the Covid-19 pandemic. He stated that in this period, supportive social aids were provided within the Southern African Development Community's scope, as well as the government's social aids. It was stated that in the country where cash and food aids are provided to those who have financial difficulties due to Covid-19, immigrants have challenges in accessing these aids; therefore, social media should be used actively to increase awareness, and legal regulations should be implemented urgently.

$\mathrm{Lu}$ and others (2020:1) examined the social policy transformations experienced in China during Covid-19. It is stated in the study that the government reaches the needy with social security and financial, social assistance and the new strategies developed will contribute to the creation of a healthier social welfare state.

Lustig and others (2020: 1) examined the economic effects of the Covid-19 pandemic in Brazil, Argentina, Mexico, and Colombia. They stated that in this period, governments benefited from social assistance to reduce the effects of poverty. It has been concluded that the pandemic is having an increasing impact on poverty in all countries and that social service is insufficient to prevent this poverty.

Faturahman and Harefa (2020: 19, 22-23) examined Indonesia's financial policies during the Covid-19 pandemic and the effects of these policies. During the epidemic, the Indonesian government has implemented an economic incentive policy and the implementation of corporate tax and income tax exemptions, including SMSEs, to expand employment opportunities. It has been observed that these strategies of the government are to pave the way for foreign investors to continue their investments in the country by taking the epidemic under control, and this is implemented with determination.

Gelb and Mukherjee (2020: 15-16) examined the use of digital mechanisms for the mass expansion of social transfers in the Covid-19 outbreak. They emphasized that digital instruments should be developed to inform, identify, and register people affected by the pandemic and provide social assistance to these people. It was indicated that during the epidemic process, the effective use of digital renewal by expanding administrative databases and mobile applications' development would encourage more use of digital platforms. In the study, it was concluded that the effective use of digital mechanisms for social protection and assistance is expected to progress with the Covid-19 pandemic experiences.

Akca and Küçükoğlu $(2020: 71,80)$ made evaluations about the method of working from home in their studies, where they examined the effects of the Covid-19 epidemic on 
business life. In the study, it was stated that the concept of working from home had become an alternative strategy for businesses with the Covid-19 pandemic. The advantages and disadvantages in terms of jobs that are suitable for the home-working model have been presented, and recommendations have been made. In the study, it was concluded that the home-working model would give a new direction to digital competition and bring innovations, and the experiences of home-workers during the Covid-19 pandemic will be influential in its development.

Birinci and Bulut (2020: 62, 68) evaluated the effects of the Covid-19 outbreak on disadvantaged groups and assessed the social services carried out for these groups during the epidemic. Measures taken during the epidemic in the world and Turkey have been discussed in the context of social services. In the study, it was stated that public institutions, voluntary organizations, and local governments that provide social services should carry out intensive work for disadvantaged groups.

Cantekin and Arpac1 (2020: 1138, 1145) examined the economic, social, and health problems caused by the movement restriction applied to prevent the spread of the epidemic during the Covid-19 pandemic. In particular, they emphasized the importance of social services in preventing social diseases caused by social isolation. They summarized the social services performed during the Covid-19 pandemic in the world and Turkey. In their studies, which stated that social therapy, rehabilitation, and care models should be developed in the elimination of social diseases, they concluded those who lost their jobs during the epidemic or who have difficulties with the decrease in the demand for those working in service sectors such as hotels and restaurants need social services, and social workers have an essential role in solving this situation.

Gencer (2020: 35, 40-41) examined the official and voluntary services offered to people over 65 years of age during the Covid-19 pandemic in his study. During Covid-19, it was concluded that the elderly citizens should be given religious and spiritual support so that they do not feel lonely and do not feel anxiety and stress due to uncertainty.

Kara $(2020: 269$, 279) examined the effects of the Covid-19 pandemic on the workforce and the employment measures taken. In the study, the effects of the crisis that started with the epidemic on the workforce and work were discussed. Data and measures taken in the world and Turkey were examined. As a result of the study, it was revealed that those who were employed in sectors that were significantly affected by the crisis at high and medium-high levels were affected, and the effects of the crisis were different on a sectoral basis, so states should take more inclusive measures for those working in the sectors affected after the epidemic.

Kara (2020: 28) examined the effects of social services carried out for disadvantaged groups on the workforce in the Covid-19 pandemic. In the study, the effects of the epidemic on disadvantaged groups were discussed within the post-epidemic literature scope. It was concluded in the study that the need for social workforce for mental health and psychosocial, public health, family, women, children, the elderly, for the development of communication and social solidarity increased.

Yavuz (2020: 181) examined the effects of the Covid-19 pandemic on social politics. Stating that the changes in social politics took place after global crises, the study states that the global crisis created by the Covid-19 pandemic will also bring changes in social politics. It was emphasized that these changes could be associated with the size of the crisis, the welfare models implemented by countries, and the cooperation between social policy implementing institutions. It is stated that governments will act more interventionist in 
the field of social protection, and in this context, ideologies that limit governments' intervention in social and economic life will regress.

Yelboğa and Aslan $(2020: 43,47)$ examined how epidemic diseases affect public health and the social problems they create in their studies in the context of globalization and public health. They tried to formulate new strategies that should be followed in social studies to improve and protect public health. They stated that the psycho-social-economic problems created by the Covid-19 pandemic had a more significant impact on disadvantaged groups such as the elderly, children, women, and disabled people; therefore, within the frame of the advocacy of individuals and society in the context of the social state understanding, new applications need to be developed with multi-faceted interventions from micro to the macro level.

Yürekli (2020: 34, 58) stated that in his study examining the effects of the Covid-19 pandemic on working life, different measures were taken to prevent the employees from being harmed. He examined the actions taken within the legal frame. As a result of the research carried out, he stated that it would be appropriate to work remotely in business lines where remote work can be done and to take all precautions in cases where it is necessary to go to the workplace..

According to Yorgun (2020: 100), the Covid-19 pandemic shows its effect mostly on social problems and expenses. While social spending is increasing, the crisis conditions experienced highlight the resource problem. Also, it is seen that countries are caught unprepared for the epidemic due to their existing health systems, economic structures, and the share they allocate to social expenditures. Undoubtedly, under these conditions, needy people such as the unemployed, the poor, and the homeless feel the emotions such as risk, uncertainty, and insecurity more intensely. However, as the process progresses, it is seen that the wealthy segments of society also share the same feelings.

Within the scope of the literature on the Covid-19 pandemic, it has been observed that studies on socio-economic problems have been conducted. Most of the studies have examined governments' policies during the epidemic by reviewing social assistance and services for those who lost income and disadvantaged groups. Studies in the literature consist of descriptive studies that determine the situation. In addition, many studies draw attention to the decreasing level of welfare and the increasing need for social security during the epidemic. Many risks, such as the extent of healthcare services, employees' concerns about job and income security are tried to be covered by social security systems, and various practices are implemented. Many applications such as the restriction of the freedom of employers dismissal, financial support for employers, and the introduction of short-time working allowances are among the measures taken in Turkey.

In addition to these, public social security expenditures, which constitute another pillar of social security systems, are also put into effect. In particular, the scope and effectiveness of social assistance and service practices that will protect the disadvantaged groups of the society seem very important for these groups to lead a life worthy of human dignity during the pandemic. In this study, social assistance and services carried out by the government in Turkey during the pandemic will be handled with qualitative research techniques, and the deficiency in this field will be tried to be eliminated with an explanatory study. 


\section{THE SOCIAL ASSISTANCE AND SERVICES IN TURKEY DURING COVID-} 19 PANDEMIC

The Covid-19 pandemic has caused significant economic, social, and political impacts, as well as containing a global epidemic threat. With the epidemic conditions, large segments of society faced risks and uncertainty, and economic concerns replaced health concerns. Undoubtedly, the most affected by this pandemic are the disadvantaged groups that constitute society's most vulnerable segments. It is possible to say that the insufficiency of social policy measures in many countries makes these groups more vulnerable. Crisis conditions, faced with the global epidemic's impact, have led to the deepening of social problems such as unemployment, poverty, and inequality in many countries.

The pandemic that affected the whole world also quickly showed its influence in Turkey's social and economic spheres. Restriction measures have been taken to reduce the rate of spread of the disease. In this process, the implementation of social services and assistance that will cover the general public and especially the private groups in need of protection is accelerated. An important part of Turkey's social assistance and service programs during Covid-19 was realized through the Social Assistance and Solidarity Foundations. According to the statements made by the Ministry of Family, Labor, and Social Services, social assistance and services are as follows (www.ailevecalisma.gov.tr):

$>$ After the emergence of Covid-19 in Turkey in March, shares transferred to the Social Assistance and Solidarity Foundations's regularly every month were increased from 135 million liras to 180 million liras. As of September, the total amount of additional funds reached 715.2 million liras. During the outbreak, a total of 2 billion TL periodic share was sent with additional resources.

$>$ Besides, within the scope of the Economic Stability Shield Package, it is aimed to provide cash support of 1000 TL to those in need. The said cash support payments are made in periods. As of November, payments were made in three phases, 2,111,254,000 TL in the first phase, 2,316,010,000 TL in the second phase, and $1,882,840,000 \mathrm{TL}$ in the third phase.

$>$ A series of measures have been taken for homeless citizens, who are among the most affected by Covid-19. These citizens are accommodated in public institutions, guesthouses, hostels, pensions, and during this period, the Social Assistance and Solidarity Foundations meets their cleaning, health, food, clothing, and other needs.

$>$ There has been an increase in the social assistance granted to women. In this context, conditional birth aid was increased to $100 \mathrm{TL}$, and the amount paid within the scope of the Assistance for Women whose Spouses Deceased Program was increased to $325 \mathrm{TL}$.

$>$ To minimize the risk of contamination in nursing homes, 64 million TL was sent to purchase cleaning, laboratory, medical equipment, medicines, and other special materials.

$>$ Covid-19 Psychosocial Support Service is provided by phone for those who are in isolation, or who are under quarantine in the dormitories and are affected by the pandemic, who have various problems, feel unhappy, who have disabled individuals in their households and taking care of them and who have trouble due to being at home all the time. Supports are provided by a staff consisting of 
psychologists, psychological counselors, and social workers. People over the age of 65 are called without request, their needs are asked, and moral support is provided.

> The soup kitchen services' capacity has been increased from 38,442 to 39,484 , and a total of 38 million TL budget has been transferred to the soup kitchens.

$>$ In order to support the needy, "Together We Are Enough My Turkey" national donation campaign was launched. The collected donations were distributed within the scope of the Social Protection Shield Program carried out by the Ministry of Family, Labor, and Social Services. As of 06.11.2020, a total of 2,038,550,000 TL aid was collected.

$>$ Various programs for disadvantaged young people have been put into effect, and approximately 1000 people have been provided with assistance. In addition to social and economic support, young people raised under the protection of the state and left the institution as an adult were supported with the aid models of the Social Assistance and Solidarity Foundations. Employment rights, housing support, private sector support, dowry support, adaptation to business life, and counseling support were provided to the young population.

These measures to combat the Covid-19 pandemic in Turkey have brought significant criticism from the public and social sides. In particular, the limited scope of the aid and services provided, the inefficient use of resources, and the problems in accessing aid and services by the needy citizens constitute the main sources of these criticisms. This issue has caused various discussions in political environments, written and visual media, and social media. In this context, through the written press in Turkey, criticized and supported issues of the management of social assistance and services for needy and disadvantaged groups with the emergence of Covid-19 pandemic were tried to be revealed.

\section{METHOD}

The qualitative analysis method was used in the research. Research data were collected by the document analysis method. The documents were coded at word, sentence, and paragraph levels using the MAXQDA 2020 Project program, and content analysis was made.

\section{Purpose and Significante}

The research aims to reveal the role of the written press in Turkey in identifying problems encountered in managing social assistance and services for the needy and disadvantaged population throughout the Covid-19 pandemic. There are various news and columns on this subject in the print media in Turkey. While the opposition groups criticize 
government practices, there are also those who see them urgently and rightly. The research is important in terms of revealing the problems that may be encountered in the social service and assistance process in extraordinary situations such as the Covid-19 pandemic, and also in terms of guiding the authorities in their decisions in the face of similar extraordinary situations that may occur in the future.

\section{Design}

The style of thinking and approach in determining the methods and strategies followed in research is called design. While creating researches, they are designed as quantitative, qualitative, and mixed research designs. This research has been prepared as a case study from qualitative research designs. In the case study design, one or more events or persons are used to understand a subject, fact, or problem (Güler vd. 2015: 173, 301, 307). In the case study design, various aspects of the subject event or phenomenon are revealed by looking at the research subject from multiple angles. In the case study design, holistic event, multiple holistic event, nested single event, and multiple nested event pattern can be used. In this study, a multiple holistic case study was preferred. In the multiple holistic event design, multiple event patterns are considered holistically. Each event is taken as a whole in itself and then compared with each other (Gürbüz ve Şahin, 2018: 413-416; Yıldırım ve Şimşek, 2016: 301). In this research, answers for the "In what extent are the social aids and services provided during the Covid-19 pandemic covered in written press reports and columns?" question were searched. The research is based on the premise that the printed media can play a role in revealing the disruptions hidden by governments in social assistance and service processes in extraordinary situations such as a pandemic.

\section{Extent and Limits}

The research scope is the national written press, which broadcasts in Turkey and has a website. However, a limitation has been made since the legibility level of all these press organs is not the same, and some of them produce news supporting the government and the other part criticizing the government. Among the national print media that publishes on social services and assistance provided by the government during the pandemic, those who have a website were selected for the purpose. In this selection, it was tried to include print media that both support and criticize the government. In this context, Sabah, Hürriyet, and Yeni Akit publications were selected as pro-government newspapers, and Cumhuriyet, Sözcü, Birgün as critical of the government were included in the research. Again, the fact that these national newspapers were selected as an example was the high number of news and columnists on social services and government assistance during the Covid-19 pandemic.

\section{Validity and Reliability}

In qualitative research, the concepts of validity and reliability are used with the notions of internal validity-credibility, external validity-transferability, internal reliability- 
consistency, external reliability-verifiability. Credibility is about the authenticity of the findings, the validity of the research results in similar environments, the consistency of the processes with each other, the collection and presentation of the data with an objective approach. It also states to what extent the researchers' findings and results reflect the things participants said. Consistency refers to the fact that the researcher looks at the research from an external perspective and acts consistently in his research activities from beginning to end (Yıldırım ve Şimşek, 2016: 277- 283). Research data were collected from the websites of the examined newspapers. Therefore, everyone has access to these documents, and the situation proves the truth of the findings. While collecting data, it was tried to be collected and presented objectively and consistently as possible. In qualitative research, it is impossible to represent the environment in which data is obtained in the same way in other similar samples. For this reason, the concept of transferability is used instead of the concept of generalizability. Ensuring transferability in qualitative research depends on detailed description and purposeful sampling methods (Yıldırım ve Şimşek, 2016: 281-282). In order to ensure transferability, the way followed in the research, the method used, and the analysis technique are explained in detail. Again, through purposeful sampling, newspapers that were thought to reflect the news that both supported and criticized the government were examined. In qualitative research, the concept of consistency is used instead of internal reliability. Within the scope of consistency, it is stated whether the research is viewed from an external perspective and whether the researcher acts consistently in research activities from beginning to end (Yıldırım ve Şimşek, 2016: 283). In this study, research was tried to be viewed from an outside eye, and care was taken to be consistent in collecting data, coding, and analysis processes as much as possible In qualitative research, verifiability instead of external validity is the confirmation of the results with the collected data and a logical explanation to the reader (Yıldırım ve Şimşek, 2016: 283). The research data and findings confirmed the study results, and a logical explanation was tried to be presented to the reader.

\section{Data Collection Method and Analysis Technique}

Research data were collected by the document analysis method. Document review includes the analysis of written materials that contain information about the phenomenon or facts to be investigated (Ylldırım ve Şimşek, 2016: 189). Public records, personal documents, popular culture documents, visual and physical materials, documents produced by the researcher are counted among the document types (Merriam, 2013: 132141). In the context of this research, column articles about social assistance and services were recorded and turned into a document between the day of the first Covid-19 case emergence in Turkey, 10 March 2020 and 15 December 2020, from the websites of newspapers "Cumhuriyet, Sözcü, Birgün, Sabah, Hürriyet, Yeni Akit, and Türkiye". The data were analyzed using the content analysis technique. Content analysis is a technique related to mass communication research. However, it is also used in sciences where textual data are analyzed. Content analysis is independent of the theoretical point of view. Although there is no generally accepted standard in the method, it is not used completely randomly (Güçlü, 2019: 168). The content analysis does not have a simple classification process, and it aims to introduce, demonstrate, and show. In other words, the expression 
of a grouping that serves the purpose of clarifying the meaning of the facts and a process of creating evidence regarding the meaning (Bilgin, 2014: 2). With the content analysis, it is tried to define the data and reveal the facts that may be hidden in them. In this context, similar data are gathered within the frame of certain concepts and themes and interpreted so that the reader can easily understand. In content analysis, coding can be done at the level of word, sentence, paragraph, or the entire text (Ylldırım ve Şimşek, 2016: 242-243). In the research, using the MAXQDA 2020 Project program, the content analysis was started by coding the documents at word, sentence, and paragraph levels. In this analysis, no coding was made above the paragraph level. The determined themes are "social assistance and social service." Then, the relationship between the codes, themes, and each other was examined, and the research questions were tried to be answered.

\section{RESULTS}

Within the research scope, the news published in the national press on social assistance and social services during the Covid-19 pandemic process in Turkey was analyzed under two main themes. Both themes are divided into sub-themes. The themes were analyzed by comparing the news published in newspapers supporting and criticizing the government.

First, the study's theme and sub-codes were specified using the "Code Matrix Browser" tab of the MAXQDA 2020 Project Program. Two themes and eight sub-codes related to them were determined from both the literature review and the data processing.

While creating subcodes, news, and columns about the Covid-19 pandemic were scanned online and divided into two as criticizing and supporting the government. News criticizing the government is coded as Opposition in sub-codes, and news supporting the government is coded as Power in sub-codes. 
Figure 1. Determined Themes and Codes

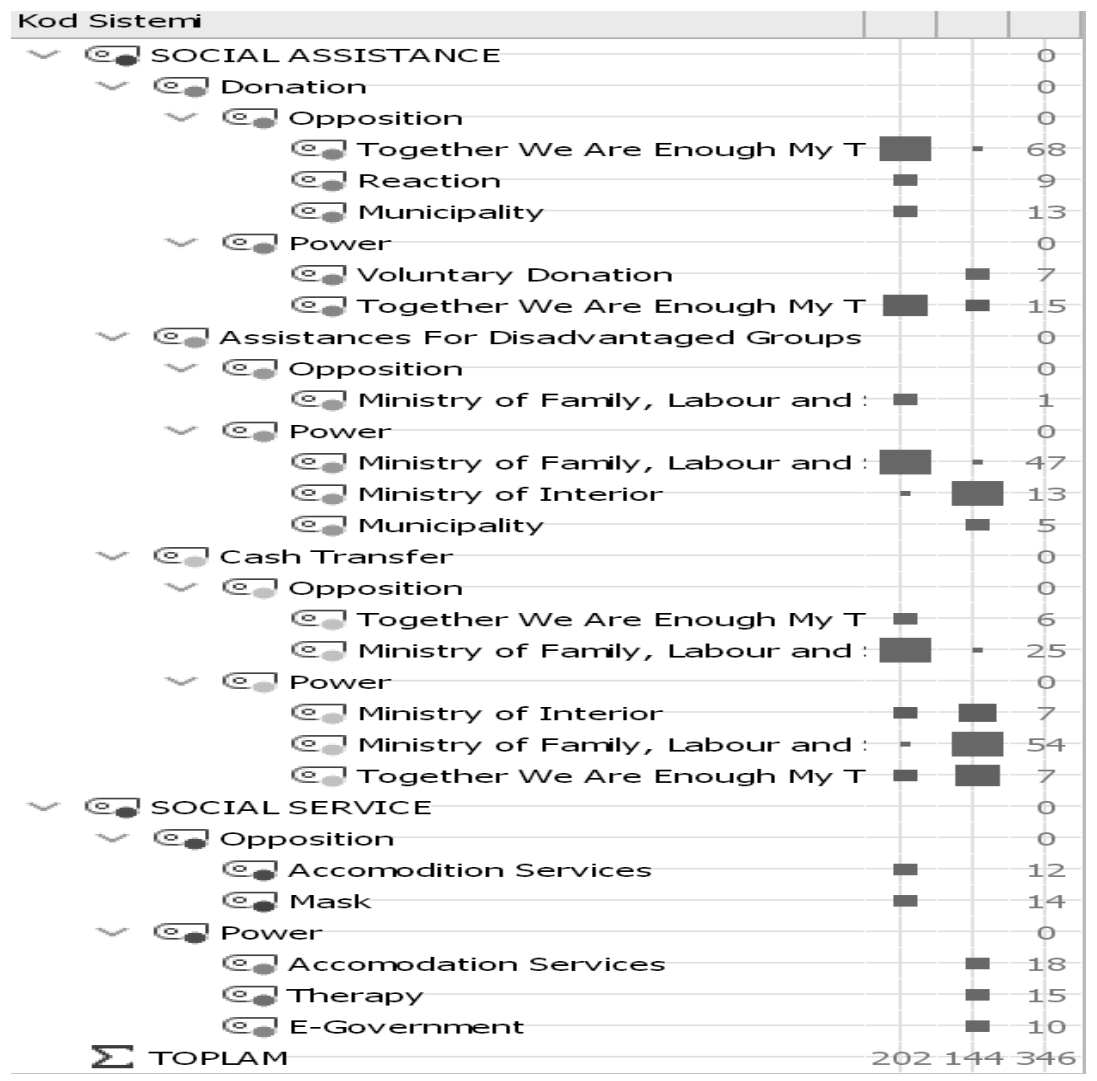

In Figure 1, social aids are divided into sub-codes as donation, assistance for disadvantaged groups, and cash transfer. Under each sub-code, news and columns that criticize and support the government are separated.

The first sub-code is discussed under the name of donation. There is Together We Are Enough My Turkey, Reaction, and Municipality sub-codes under the sub-code named donation. These sub-codes are the most emphasized issues in articles criticizing the government. Power sub-code includes voluntary donation, and Together We Are Enough My Turkey sub-codes.

Together We Are Enough My Turkey campaign is the most reported topic under Power sub-code, while voluntary donation takes the second place. As seen, the most criticized and supported sub-code under Donation code is Together We Are Enough My Turkey 
campaign. One of the criticisms under Municipality sub-code is the government stopping aid campaigns initiated by the municipalities and that the campaigns should be carried out by the municipalities all along. News under the sub-code Reaction are about those who do not participate in the We Are Enough My Turkey campaign and react.

Assistance to disadvantaged groups during Covid-19 is included in the second sub-code. This sub-code is also divided into Opposition and Power. In the Opposition sub-code, the Ministry of Family, Labor and Social Services was coded with this name because its aids were criticized most, and the Power sub-code was divided into three as the Ministry of Family, Labor and Social Services, the Ministry of the Interior and the Municipality.

Cash transfers made during the Covid-19 pandemic were also subjected to a similar division. Opposition sub-code includes Together We Are Enough My Turkey campaign, Ministry of Family, Labor and Social Services, and the Power sub-code was divided into three as the Ministry of Family, Labor and Social Services, the Ministry of the Interior, and Together We Are Enough My Turkey campaign.

Social service theme is also divided into Opposition and Power sub-codes. The most criticized headings are included under the Opposition sub-code. Opposition sub-code is divided into two sub-codes, and these are accommodation and mask services. It is seen that there is more emphasis on criticisms about mask services. Power sub-code is divided into three as accommodation services, therapy (psycho-social support), e-government. Among these three sub-codes, accommodation services are the most emphasized, followed by therapy services and e-government services, respectively. 
Figure 2. Social Assistance Hierarchical Code-Sub-Code Model

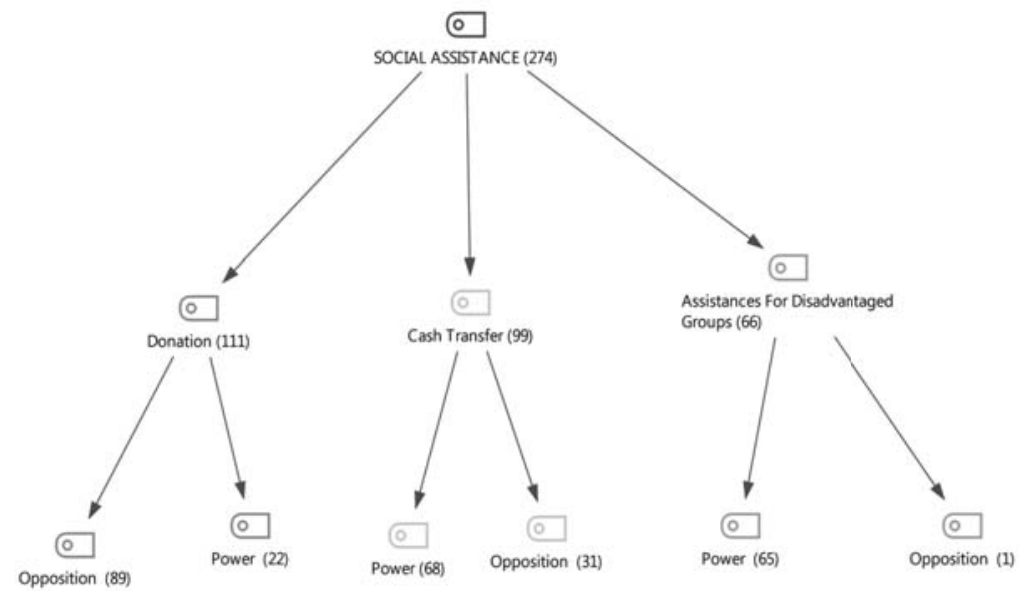

The codes and sub-codes under the social assistance theme are shown in Figure 2. The Hierarchical Code-Sub-code Model was created by selecting "New Code Model" from the MAXMaps section of the MAXQDA 2020 Project program's Visual Tools tab. The same method was used for the theme of social service. The theme of social assistance has been categorized under three headings as donation, cash transfer, and assistance for disadvantaged groups, and each code is divided into two sub-codes: criticizing (opposition) and supporting (power) government. Donations related to social assistance were the most repeated. In the donation code, the criticisms are more repeated than the supporting articles. Second, cash transfers were repeated. Cash transfers have been featured more frequently in articles supporting the government. Finally, there is social assistance provided to disadvantaged groups. Assistance for disadvantaged groups has been emphasized more in the articles supporting the government.

When the newspapers and columns are examined thoroughly, it's understood that the hottest topic for both criticizing and supporting newspapers was Together We Are Enough My Turkey campaign. Statements made by the President and the Ministry of Family Labor and Social Services regarding the campaign were reported throughout the campaign in all newspapers supporting the government. In the newspapers criticizing the government, the campaign is criticized as follows: First, as a social state requirement, social expenditures during the pandemic must be met by the government. First, organizing campaigns and collecting aid from poor citizens is an indication of inability. The second is that the government is in a position to seek help from its citizens due to the improper use of country resources. The third is that the collected money is not spent in line with its purpose, it is not delivered to the needy, and the government is not transparent about the expenditures. Also, attempts to prevent donation campaigns 
initiated by opposition municipalities were also on the agenda of national press organizations broadcasting against the government. Below are some direct quotations from the newspaper reports for some of these criticisms.

\section{Regarding the "opposition" code under the donation sub-theme in Figure 2:}

"While President Erdogan of the AKP demanded alms and donations against the epidemic crisis, the government also monopolized the aid campaigns. The Ministry of the Interior took action against the campaigns launched by the Istanbul, Ankara, and Izmir metropolitan municipalities to help citizens with economic difficulties. In the notice sent by the Ministry to 81 provincial governorships, it was requested to prosecute all aid collection activities outside the scope of the Aid Collection Law. Following Soylu's notice, Vakifbank account of the Istanbul and Ankara metropolitan municipalities were blocked" (Birgün, 01.04.2020).

"Due to the coronavirus epidemic, 'donation' orders have been given to teachers that are far from their schools and students since March 16. In the message sent to the schools' internal correspondence groups, administrators and teachers were asked to collect money for the Together We Are Enough My Turkey campaign initiated by President Erdoğan and send the receipts to the provincial and county national education directorates. (...) After President Recep Tayyip Erdogan of the AKP donated his salaries to the Together We Are Enough My Turkey campaign, national education directors took action. It was alleged that the principals put pressure on school administrators and teachers to increase their participation in the campaign" (Birgün, 01.04.2020).

"Erdoğan government is constantly opening new loans to the public, registering as an item in the general budget instead of distributing the aid money collected from the public with the IBAN number. The public's debt to banks was 6.6 billion TL in 2002; today, this figure has increased 100 times and reached 660 billion TL. While it is possible to support citizens with direct aid, on the contrary, they are giving loans that the public obviously cannot repay. Citizens in a spiral of unemployment, financial difficulties, and hunger also apply for these loans that they cannot pay back" (Cumhuriyet, 06.08.2020).

"What happened to this money you collected? For what purpose and in what area do you use them? In other words, where did this collected money go, which groups benefited from it? Two quadrillions with the old money... Unfortunately, they were never able to answer. As the state, government, and presidency, you will collect such a large amount of money, but you will hide where you spend it from the donor Turkish Nation! .. Do the law accept this, let alone law, does the conscience? How would you explain this to maybe hundreds of thousands of ordinary citizens who put money into that bank and contributed like 10 lira?" (Sözcü, 14.05.2010). 
Regarding the "power" code under the donation sub-theme in Figure 2:

"Zehra Zümrüt Selçuk, the Minister of Family, Labor and Social Services, stated that from the donation of more than 2 billion Turkish lira collected from Together We Are Enough My Turkey campaign, they brought 1000 lira to 1.2 million households in need and that the support and assistance provided under the Social Protection Shield approached 30 billion lira. In her written statement, Selçuk stated that more than 2 billion donations had been made to Together We Are Enough My Turkey campaign so far. Stating that the state and the nation together, we continue to support citizens affected by the coronavirus epidemic and that the aid is delivered to the citizens in need, Selçuk said, "We provided 1000 lira in cash support to 1.2 million households in need. We continue to deliver the remainder of the amount collected under the campaign to households in need." Minister Zehra Zümrüt Selçuk, who also shared information about the payments made in the Social Protection Shield, announced that the support and assistance provided to citizens within the scope of the "Social Protection Shield" had approached 30 billion liras" (Yeni Akit, 13.12.2020).

"President Erdogan made a speech to the nation after the critical cabinet meeting: (...) Since we see that the state should lead in this issue, we are launching a National Solidarity Campaign. For this campaign that we started by saying, "Together we are enough my Turkey," our Ministry of Family, Labor and Social Services has opened an aid account whose information is currently on the screen (...) Of course, some of our ministers also stated much higher donation figures. We invite all of our parliament members, organizations of all our parties, especially the AKP, all our mayors and bureaucrats to participate in the campaign. Of course, we expect the biggest contribution of our businessmen and philanthropists. (...) Citizens who intend to distribute their alms in Ramadan can also participate in this campaign and take their place in the charity race" (Sabah, 03.30.2020).

In the news and columns on social assistance provided to disadvantaged groups, it is seen that news being featured about increasing the amount of existing social expenditures and adding new social expenditure items within the scope of Covid-19 pandemic measures. Aids for the poor, women, the elderly, youth, children, and disabled people, who constitute the economically and socially vulnerable segments of the society, have been examined under this theme. It is seen that the news regarding the aid took place in all media organs that support and criticize the government. The emphasis on the effectiveness of aid, its proper use, that it covers all socially risky segments of the society, and that aid amounts are increased stands out in all media organs supporting the government. On the other hand, in the newspapers criticizing the government, it was emphasized that even though aid was increased, it was far from preventing poverty and protecting disadvantaged groups. This issue has been discussed in the newspapers as follows: 
Regarding the "opposition" code under the assistances for disadvantaged groups sub-theme in Figure 2:

"PTT Ulus Branch was not closed the day when we arrived at it. The queue is longer, and the distance is not taken into account. The constant warnings of security guards are quickly forgotten. A retired citizen of SSK says that he received a message on his mobile phone and he came to get "1000 TL of aid". A woman who did not want to be named said, "My husband is a porter. I have two children, and we live in the concierge flat. We have no insurance, " Meanwhile, a masked officer warns, "Those who do not receive messages should not wait." I ask her, “Did you receive the message?" “No, it didn't, but I am waiting for hope, maybe they will give it to me, too." she answers. When I asked, "Are you staying at home?" She said, "I am staying with the children. My husband leaves in the morning, hoping that he might find a job, but every workplace is closed. "Even in poverty, inequality stands out instantly. 1000 TL for SSK retirees, nothing for an unemployedinsecure porter. They were only getting help from the municipality. The question "Does anyone else know about these people" haunts our minds" (Cumhuriyet, 04.04.2020).

"In the first half of the year, a monthly aid of $805 \mathrm{TL}$ was made to poor citizens over the age of 18 and under the age of 65 , who are at least 70 percent disabled and unable to survive without the help of anyone else. This amount was increased to 851 TL for the second half of the year. The amount of monthly aid paid to the disabled people with disabilities at the rate of 40-69 percent who can meet their own needs increased from 537 TL to 567 TL. Monthly payments made to low-income families with disabled children under the age of 18, with at least 40 percent, rose from 537 TL to 567 TL in the same way, monthly payments made to poor citizens over the age of 65 increased from $672 \mathrm{TL}$ to 711 TL. To benefit from the 65-year-old pension, you must not be receiving income or pension from the Social Security Institution, not getting alimony, or not be able to get alimony. (...) The allowances given to those staying in social service organizations such as nursing homes and orphanages will also increase. It will increase from 247 TL to 261 TL for the elderly, from 99 to $104 \mathrm{TL}$ for the disabled between the ages of 6-12, from 148 TL to 156 TL for the disabled between the ages of 13 and 18, from 198 TL to 209 TL for the disabled over 18" (Cumhuriyet, 07.07.2020).

Regarding the "power" code under the assistances for disadvantaged groups subtheme in Figure 2:

"Minister Selçuk stated that the amounts paid in the aid programs were increased by the President Erdoğan's approval; 'In these days when we are struggling with coronavirus, we increased the amount paid to women in social assistance; "We increased the Conditional Birth Aid to $100 \mathrm{TL}$ and the amount paid for women who have deceased spouses to 325 TL." (...) Reminding that all services related to social protection are gathered under the roof of the Ministry of Family, Labor and Social Services together with the Presidential Government System, Minister Selçuk; "In this process, we develop and implement policies that capture the spirit of the times, manage change, prevent social risks" (Sabah, 11.04.2020). 
"To prevent the spread of the coronavirus, the Ministry has implemented strict measures in all institutions, from nursing homes to disabled care and rehabilitation institutions, from women's shelters to children's homes, and made new decisions to protect needy citizens against the economic effects of the epidemic. In this context, there was a significant increase in the "periodic share" transferred to 1003 Social Assistance and Solidarity Foundation carrying out the work of community social services for disadvantaged groups across Turkey by the Ministry. By increasing the financial resources in question, it is aimed that more people will benefit from the social assistance provided to the citizens in need" (Türkiye, 24.03.2020).

"Zehra Zümrüt Selçuk, Minister of Family Labor and Social Services, stated that they have been following young people who are raised under state protection more intensely in the process of combating Covid-19 and that approximately 1000 young people have been supported by financial support and their employment in the private sector has been realized. (...) Minister Selçuk emphasized the importance of being with young people during the epidemic who were raised under the state protection period and left the institution as an adult, and shared the following information about the works: Our experts reached about 1000 young people in the process of combating coronavirus. In addition to Social and Economic Support (SED), we also supported our young citizens with Social Assistance and Solidarity Foundations' aid models. They also benefited from support such as private sector employment incentives, short-time work allowance, and unemployment allowance if they meet the conditions" (Hürriyet, 18.06.2020).

"With a written statement from the Ministry of the Internal, within the scope of coronavirus measures, those aged 65 and over and those with chronic diseases were prohibited from going out. 'Vefa Social Support' groups were established under the coordination of governorships for those who live alone and do not have relatives to meet their needs. "Vefa Social Support" groups consist of public employees such as police, gendarmerie, guard, AFAD personnel; citizens' needs were reported by calling '112', '155', '156' and other numbers. While citizens were calling these numbers to get their needs, such as grocery shopping, health, and hygiene is taken care of, some people called to have their salary withdrawn and get their field plowed. Vefa Social Support groups received 1.156.197 calls between March 22 and April 2; 427.530 calls over '112', 236.225 calls over ' 155 ', 91.842 calls over ' 156 ', and 400.600 calls from other numbers. 1.027 .000 of these calls were responded to, and their requests were fulfilled. More than 129,000 requests were met by directing them to the relevant institutions" (Hürriyet, 03.04.2020).

Within the scope of cash assistance, cash transfers made to needy segments to compensate for the economic consequences of the Covid-19 Pandemic were examined. The most important item among these is the cash support of 1.000 TL paid in three phases. Support in question was among the most reported topics in all newspapers that both support and criticize the government. In the newspapers supporting the government, it has been constantly emphasized that cash support is one of the most important tools in the fight against Covid-19, the beneficiaries' positive opinions, the effective distribution of the aid, and every citizen's coverage who needs help. In the newspapers criticizing the government, there was no positive opinion about the government's cash support. The contradictory statements of government officials regarding the number of beneficiaries and that support is far from compensating for the consequences of unemployment and 
poverty are the main criticisms. Explanations on the subject in the newspapers are as follows:

\section{Regarding the "opposition" code under the cash transfer sub-theme in Figure 2:}

"There is a massive difference between the number of households announced in the cash support payments paid to citizens and the number of households in official records! While the total number of registered households benefiting from social assistance for 2019 was $3,209,000$ in official data, the total number of households in phase 1 and phase 2 were registered in the minister's statements in various media outlets, reported as $4,411,000$. We are asking! Why is there a 1,200,000 household difference between the number of registered households benefiting from social assistance in official data and the number of households announced by the minister? Do the 1,200,000 households not in official records consist of those who are not in need and vote for your party? Or are the records duplicated?" (Birgün, 14.04.2010).

"The country's conditions do not affect the government's spending choices. Despite the economic picture worsening with the epidemic's effect, the "transfers to households" item of the budget fell to the lowest level of 2020 in August. The 1.3 billion TL transfer made from this item was below the 1.6 billion TL transferred to the contractors. Ministry of Treasury and Finance announced the budget realizations for August. There was no significant decline in spending, which were considered as black holes in the budget. However, the payments used by the AKP governments for aid purposes, especially during election periods, slowed down. "Scholarships and allowances, education, health, food, housing, agricultural transfers, transfers for social and economic purposes" items of the budget declined despite severe epidemic conditions. Transfers made for eight months reached 43.9 billion TL. The transfers were 6.7 billion TL in January, 7.5 billion TL in February, 7.4 billion TL in March, 5 billion TL in April, 4.3 billion TL in May, 5 billion TL in June, and 6.4 billion TL in July. decreased to 1.3 billion TL in August" (Birgün, 16.09.2020).

"In the five months since the epidemic, 7.2 billion TL cash payments were made to 7.2 million low-income families, and 22.4 billion TL to 6 million workers and unemployed. While the monthly aid amount per low-income family was $222 \mathrm{TL}$, the workers received an average of 822 TL per month. It is insufficient; however you look, it is impossible to explain it from wherever you look. The Ministry of Family, Labor and Social Services announced the amount of support and the number of support provided to low-income families affected by Covid-19, workers, and unemployed people who lost their jobs and income as of August 1, 2020. It should be noted right away that during Covid-19, public officials did not successfully provide regular data to the public. While the Ministry of Health did not disclose the data on the epidemiology of the epidemic, the Ministry of Family, Labor and Social Services did not disclose regular and detailed data on social assistance and allowances. While it is possible to access partial information about İ̧KUR allowances, unfortunately, it is not possible to obtain detailed data on social assistance provided in the Covid-19 period" (Birgün, 08.03.2020).

\section{Regarding the "power" code under the cash transfer sub-theme in Figure 2:}


“Zehra Zümrüt Selçuk, Minister of Family, Labor and Social Services, said, "Our cash wage support and unemployment allowance continue. Thanks to this package, which we call social protection shield, we have provided nearly 40 billion TL support." Selçuk explained that "many measures were implemented in the working life during the epidemic, and that they were prepared for a possible situation long before the epidemic started" at Turkey Confederation of Employer Associations (TISK) hosted online meeting of Common Share Forum 2020 (...) She continued as follows: “Apart from regular aids, life water was given in the first stage. Later, we prepared a program for those who are not normally at the level of neediness but need help due to the pandemic. We also checked the declaration-based applications and discussed them with our social assistance and solidarity foundations. In this way, we transferred 1,000 TL to 1.8 million households. At the same time, we have doubled the periodic shares that we sent to our foundations. We continue this process. As soon as we identify a need, we continue to transfer 1,000 TL. On the other hand, we provide support to prevent loss of employment with short work allowance" (Sabah, 15.10.2020).

"Our main purpose is to reach our citizens. Therefore, we both developed a demandbased system, wanted to reach the families we identified through our social assistance foundations, and designed a model for our employees and employers through SGKİ̧KUR. We want to meet the needs of our citizens without leaving any gaps. Other than these, if there are undetectable citizens, phase 3 will receive on a demand basis. By increasing the periodic share of our social assistance and solidarity foundations in provinces and counties, we will also be able to reach the households determined by our foundations and governors in our provinces" (Hürriyet, 16.04.2020).

According to the joint statement of the Ministry of Family, Labor and Social Services, Ministry of the Interior, and Ministry of Transport and Infrastructure, after the evaluations, it was decided to close workplaces where social distance rules could not be applied at PTT and where there was constant density. Under the Economic Stability Shield package, payments will be made to 2,111,000 households in 81 provinces and 923 counties. As of yesterday morning, aid payments in all provinces and counties from Hakkari to Edirne, from Tunceli to Sinop, started to be given to the beneficiaries at their homes. Citizens who received aid thanked them, saying, "We thank our state and our President, the aids are coming to our door" (Sabah, 04.04.2020). 
Figure 3. Social Services Hierarchical Code-Subcode Model

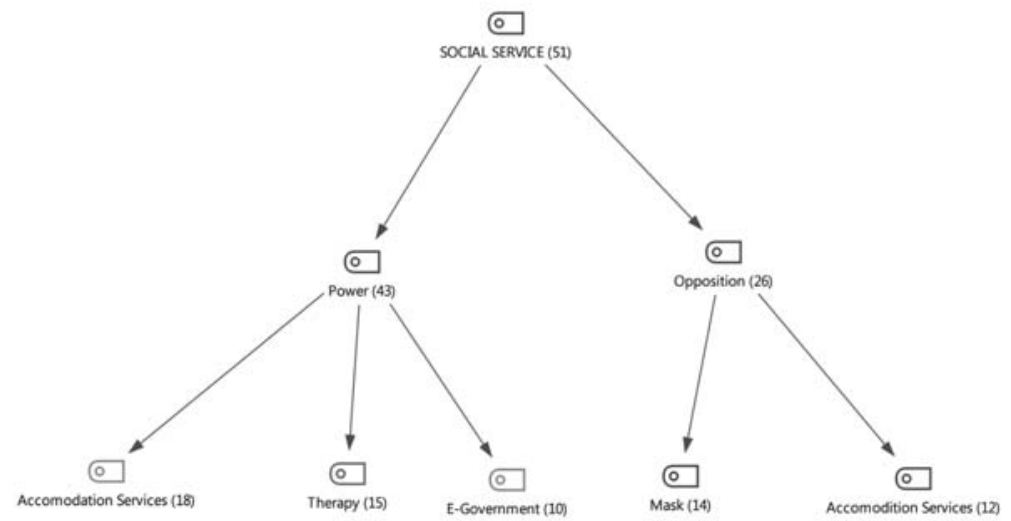

The codes and sub-codes of the social services theme are shown in Figure 3. Two subcodes were created in social services: criticizing (Opposition) and supporting (Power) the government. The most frequently repeated sub-code in articles supporting the government is accommodation services. The second sub-code is therapy, and the third sub-code is e-government. In the articles criticizing the government, the most repeated code is mask and, secondly, accommodation services.

The first of the services applied within the scope of social services against the risks created by the Covid-19 pandemic is the accommodation services available for those who need housing. In particular, services for the poor and women victims of violence have appeared in newspapers both supporting and criticizing the government. The news in question consists of the statements made by the Ministry of Family, Labor, and Social Services. No serious criticism was encountered in the newspapers criticizing the government regarding accommodation services. Explanations on the subject in the news in newspapers are as follows:

\section{Regarding the "Accommodation services" code under the opposition sub-theme in}

Figure 3:

"Zehra Zümrüt Selçuk, Minister of Family, Labor and Social Services, announced that they had taken new measures regarding homeless citizens, who are among the sections where Covid-19 disease can affect the most. (...) Homeless and alone people in the provinces will be identified and placed primarily in public institution guesthouses within the provincial borders. In case the relevant citizens cannot be placed in public institution guesthouses, they will be accommodated in places such as hostels or hotels, or a place will be allocated to these people until the threat of the epidemic disappears" (Birgün, 07.04.2020).

"Homeless and alone people in the provinces will be identified and placed primarily in public institution guesthouses within the provincial borders. In case the relevant citizens 
cannot be placed in public institution guesthouses, they will be accommodated in places such as hostels or hotels, or a place will be allocated to these people until the threat of the epidemic disappears. (...) Minister Selçuk stated that these measures sent to 81 Provincial Directorates and Social Assistance and Solidarity Foundations will be implemented immediately" (Cumhuriyet, 07.07.2020).

\section{Regarding the "Accommodation services" code under the power sub-theme in}

Figure 3:

"The Ministry of Family, Labor and Social Services provides shelter to people who are not at risk in terms of security and apply to women's shelters during the Covid-19 pandemic only for shelter. (...) In the big cities where women's shelters are located, for applications made only for accommodation without a security concern, "In cases where sheltering places are insufficient, protected persons may be temporarily accommodated in social facilities, dormitories or similar places belonging to public institutions and organizations upon the request of the local authority, the police or the Ministry in urgent cases." provision is applied within the scope of the relevant law" (Türkiye, 07.05.2020).

"The Ministry, which ensures that the inter-provincial transfers of women and children with high safety risks and their health checks before their admission to the organization are completed safely and quickly, also commissioned facilities belonging to public institutions and organizations for women who did not have the risk of violence during the epidemic, and who were decided to provide shelter only due to socioeconomic deprivation. In this context, 65 facilities, including dormitories, guesthouses, and hostels belonging to public institutions in 49 provinces, were put into women's service and their accompanying children for temporary accommodation. One thousand four hundred women and children in need of shelter benefited from these facilities" (Yeni Akit, 11.10.2020).

The economic and social problems caused by Covid-19 have increased society's need for psychological support. Newspapers both supporting and criticizing the government emphasized the increasing need for psychological support, especially as women and children are more at risk with the increase in domestic violence. When the news in the newspapers are examined, it is understood that various services for women and children are implemented. In the papers supporting the government, the inclusiveness and efficiency of the services are emphasized. In the newspapers that criticize the government, attention is drawn to the insufficiency of services and the severe obstacles faced, especially by women victims of violence in accessing these services. The news is as follows: 
Regarding the "Therapy" code under the opposition sub-theme in Figure 3:

"While many countries restrict going out to the streets with various methods due to the coronavirus affecting the whole world, citizens are warned to 'do not leave the house.' Both testimonies and studies in some countries indicate that this situation increases the incidence of domestic violence. States need to take urgent action to protect women and children who have been forced to stay with men who inflict violence on them for longer periods of time. (...) he noted that according to the information obtained from the experiences of women who reached them during the coronavirus lockdown, there were problems in admission to shelters. Underlining that assault reports are requested from women to be admitted to shelters, and this is against the law, Temizarabac1 said, "Law enforcement officers are giving misleading information to women so that they cannot go to shelters or women can be kept in police stations for hours" (Birgün, 28.03.2020).

\section{Regarding the "Therapy" code under the power sub-theme in Figure 3:}

"According to the written statement from the Ministry, efforts to combat violence against women during the Covid-19 outbreak continue with guidance, support, and guidance services. In this context, measures were taken to avoid disruptions to the uninterrupted continuation of services for victims of violence from the date of the first cases seen in Turkey. (...) Guidance and support practices for women who are subjected to violence or who are in danger of being subjected to violence and their children, family members, and individuals who are victims of unilateral stalking are carried out uninterruptedly in coordination with relevant parties" (Türkiye, 07.05.2020).

"In addition to the Ministry's support for women and children who are victims of violence, the psychosocial support practice continues online. Besides, online training was organized with 800 personnel from the Violence Prevention and Monitoring Centers and women's guesthouses. Violence Prevention and Monitoring Centers also continued their psychological counseling, guidance, and orientation services. 183 Social Support Hotline, which started to serve via WhatsApp, priority was given to victims of violence. At the same time, the intervention capacity was strengthened to ensure that victims have access to emergency assistance" (Yeni Akit, 11.10.2020).

The practical and economic logistics of the mask, which has become one of society's basic needs during the Covid-19, is one of the most discussed and criticized issues among social services. The government's statements regarding the distribution of free masks have appeared in newspapers, both supporting and criticizing the government. However, difficulties the government had in distribution and access to the mask and making it a paid service again were frequently mentioned in newspapers criticizing the government.

\section{Regarding the "Mask" code under the opposition sub-theme in Figure 3:}

"While the mask was paid, it was expensive, but somehow people could find masks. This will not go like this forever; distributing masks to the citizens aged between 20 and 65 is not enough. It is necessary to distribute masks to the entire population of the country. This is a process that might continue for one and a half years. Even if there is one per day, Turkey needs two and a half billion masks every month. But they still couldn't manage to 
give one mask. How do I get the mask? Wholesale sellers must be checked. Of course, it is humanity's duty to help people suffering from this disease wherever they may be, but the government has to meet the needs of their citizens first" (Sözcü, 14.04.2020).

"On January 10, they supposedly founded the Scientific Board. After 20 days, China has ordered and bought 200 million masks from Turkey, and they had no idea. Scientific Board member appeared on the television and said, "You don't need to wear a mask." A month later, the same Scientific Board member appeared on the same television and said, "Be sure to wear a mask." A meeting was held with the ministers. The minister appeared on the television and said, "We will sell masks to citizens." The next day, they said, "Selling masks for money is prohibited; it is absolutely free of charge. PTT will distribute the mask". The next day, they said, "pharmacies will distribute it. Five masks will be given per person "every week." The other day, they said, five masks would be given per person "in ten days." They said that the mask will never be sold with money, the free mask will be distributed to citizens between the ages of 20-65. What about citizens under 20 that you let going to work?" (Sözcü, 12.04.2020).

"One of the government's tragicomic skills is the unqualified masks that were declared to be sold for money. However, when the CHP municipalities said they would distribute it free of charge, the government announced that masks will be distributed free of charge in order not to lose the political plot to the opposition. Finally, it was decided that masks will be distributed from pharmacies for code but are prohibited from selling with money. How much money is earned from this is one of the topics we will learn in the future. Free distribution of masks by municipalities, AKP organizations' opening stands and distributing masks in the streets, even though it is prohibited to sell them with money in pharmacies, is an example of deformed cunning" (Birgün, 22.04.2020).

Below, the news in national print newspapers that are within the scope of the research, supporting and criticizing the government, are compared with the help of the "two case models" of the Maxqda Program. In two case models, the degree of occurrence of codes in related subjects in two or only one cases can be seen. It can be observed how much each of the codes is repeated according to the cases and how they are distributed. With two case models, two documents, sets of documents, sets of documents, or a mixture of these levels can be compared (see. www.maxqda.com, 2020). 
Figure 4. Two Case Model Regarding Common Themes and Codes Focused in Seven Newspapers

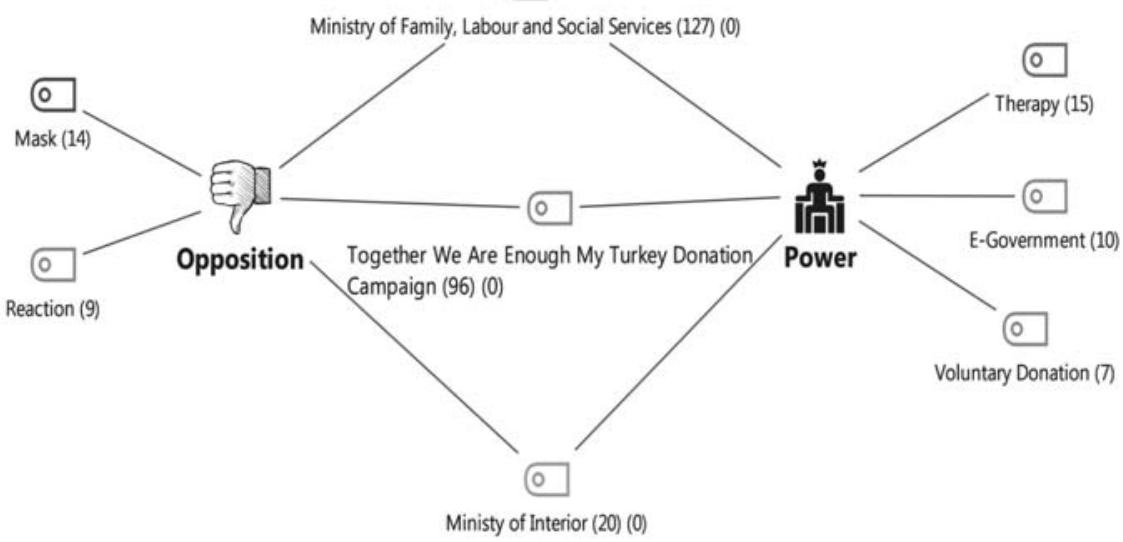

In Figure 4, there is two case model about the themes and codes that are discussed in common in the news and columns in newspapers that criticize and support the government. Two Case Model was created by selecting "New Document Model" from the MAXMaps section of the Visual Tools tab of the MAXQDA 2020 Project program. Cumhuriyet, Birgün, and Sözcü, who criticized the government with their publications, are on the Opposition theme. In the Power theme, the newspapers supporting the government with their publications are Yeni Akit, Sabah, Hurriyet, and Türkiye. Other newspapers were also examined, taking into account the same distinction, but the analysis was limited to the newspapers with the most number of news during the Covid-19 pandemic. The subject on which both groups make the most news and reports is the code of the Ministry of Family, Labor, and Social Services (127 times) shown in yellow in Figure 4. Together We Are Enough My Turkey campaign shown in orange (96 times) takes the second place while the Ministry of the Interior (20 times) in turquoise takes the third place. In the newspapers criticizing the government, the masks (14 times) and donations (9 times), which were discussed under the social service theme, were criticized. The newspapers that support the government, on the other hand, have published articles that contain statements supporting the government in the codes therapy (15 times), egovernment (10 times), and voluntary donation (7 times), which are discussed under the social service theme, unlike the critical publishers.

Social aids carried out by the Ministry of Family, Labor, and Social Services have been criticized in newspapers criticizing the government in terms of insufficient aids and not reaching citizens in need. These aids were welcomed in the newspapers that support the government in terms of delivery to the disadvantaged groups on time and to follow a correct strategy, and it was the sub-theme with the most news and columns in the media organizations in both groups. The Donation Campaign was criticized by the newspapers 
that the social state should meet the social aid without starting a campaign and that the municipalities should carry out the campaigns. In the newspapers supporting the government, it was discussed that the donation campaign launched was appropriate, that most of the people voluntarily participated in the campaign, and the implementation of the campaign by the government was welcomed. The social assistance provided by the Ministry of the Interior has been evaluated positively by the newspapers that both criticize the government and support the government. About the delivery of these aids, news and columns containing positive statements was encountered on both sides.

It is seen that the codes handled separately in newspapers that criticize the government and support the government is mostly related to social services. Among these, newspapers criticizing the government reported the public's reaction to the government's aid campaign. One of the reactions was about the mandatory donation. In the newspapers supporting the government, voluntary donations related to social assistance were discussed, and news that people from many sections of the public donated voluntarily were reported.

\section{CONCLUSION}

The Covid-19 pandemic is one of the most important events of the year 2020 worldwide, and it seems to remain in the first place in 2021. The health sector has come to the point of collapse, and economic and social life has come to a halt due to countries' not being prepared for a global pandemic. The difficulties experienced in the economic and social fields have shown that states should arrange their social policy tools, social security systems, social assistance, and service programs according to extraordinary conditions such as pandemics. In this process, academic studies on countries' social protection systems have also started to be carried out. Economic and social damage of the Covid-19 pandemic is felt in Turkey. In this context, while legislative arrangements are made in the fields of working life, social assistance, and services, new protective measures are implemented on the other hand.

In the study, an answer was sought to the question of what aspects of the government's social assistance and services during the Covid-19 pandemic in Turkey were addressed in written press reports and columns. It has been tried to objectively put forward what kind of problems were encountered in the fields of social assistance and services during the pandemic process by compiling the written press news that both broadcast progovernment and opposed to the government.

Regarding social assistance, the most touched subject of pro-government and opposition media was the "Together We Are Enough My Turkey" donation campaign launched by the government to show population solidarity in combating the pandemic.

News about the donation campaign took place more frequently in the media publishing opposition to the government than the ones supporting the government. The newspapers supporting the government emphasized the importance of social solidarity and the importance of directing society towards solidarity by the government. On the other hand, newspapers criticizing the government say that the state is experiencing economic problems due to the government's mismanagement, social benefits and services among Turkey's primary duties, and donation campaigns were made to beg money from citizens because the state was running out of money. Besides, attempts to prevent donation 
campaigns initiated by opposition municipalities by the government were criticized by opposition media because social assistance should be provided by the municipalities, which are the administrative units closest to the public, in accordance with the principle of closeness to the public.

The second most frequently discussed issue on social assistance in print media is cash transfers. Cash transfers reported more in government-backing newspapers than in opposing newspapers. Among the cash transfers, the support of $1000 \mathrm{TL}$ paid to the poor in three phases is the most on the agenda. The newspapers that support the government indicated the inclusiveness of cash transfers, which is the most important tool in reducing the economic effects of the Covid-19 pandemic, and the positive opinions of the beneficiaries. In the newspapers criticizing the government, it was pointed out that the amount of aid was insufficient to compensate for the risk of unemployment and poverty and the inconsistency of the statements made about the number of beneficiaries.

Thirdly, concerning social benefits, assistance for disadvantaged groups was mentioned in the discussed newspapers. These include aids made by the government to groups such as women, the elderly, the disabled, children, young people, and the poor. The newspapers publishing opposition to the government have criticized the amount of support and the fact that it does not cover all disadvantaged segments. Pro-government newspapers emphasized the effectiveness and inclusiveness of the support.

Under the social code, in terms of frequency of repetition, mask distribution, housing assistance, psychological support and e-government services are the most frequently reported topics. The news about the distribution of masks is the most criticized issue in the opposition newspapers. The problems experienced in the distribution of masks and the re-charging for the masks, which were announced to be distributed free of charge by the government, are the most criticized issues by opposition newspapers. Although there is news in every supporter and opponent newspaper regarding housing services, there is no significant criticism. Supporting and opposing newspapers on psychological support emphasized the importance of such services due to socioeconomic difficulties. It was stated that various psychological support services related to women and children were implemented. Opposing newspapers highlighted the problems faced in accessing psychological support services, especially for women victims of violence.

When the literature is evaluated, it is seen that the studies conducted are descriptive studies based on government statements regarding social assistance issues during the pandemic process, not based on qualitative or quantitative data, since the Covid-19 pandemic is a very current issue (see İslam ve Diğerleri (2020: 389), Dafuleya (2020: 251, 265), Lu ve Diğerleri (2020: 1), Lustig ve diğerleri (2020: 1), Faturahman ve Harefa (2020: 19, 22-23), Gelb ve Mukherjee (2020: 15-16), Akca ve Küçükoğlu (2020: 71, 80), Birinci ve Bulut (2020: 62, 68), Cantekin ve Arpac1 (2020: 1138, 1145), Gencer (2020: 35, 40-41), Kara (2020: 269, 279), Kara (2020: 28), Yavuz (2020: 181), Yorğun'a göre (2020: 100). While some studies are evaluated in terms of public health, (see Yelboğa ve Aslan 2020: 43, 47), some studies are related to economic problems that may arise due to employees' inability to participate in economic life (see Yürekli 2020:34,58). In this study, the government's social aids and services were analyzed through qualitative research through the news and columns in the printed media, and the problems encountered were tried to be revealed objectively.

As a result, in the news and columns on social assistance and services, it is seen that the printed media that both criticize the government and support the government clearly 
reveal their ideological stance with their discourse and news content throughout the pandemic. It can be said that opposing newspapers reporting only the disruptive and publicly criticized aspects of social assistance and services and pro-government newspapers not giving critical perspectives brings about the problem of preventing the public from being informed objectively about social assistance and services. 


\section{REFERENCES}

Aca, Z., Özdemir M. Ç. \& Alper Y. (2018). Kamusal Sosyal Yardımların Yapılabilirlik Çerçevesinde Etkinliği Analizi: Bursa Örneği, Yönetim ve Çalışma Dergisi, 2(2), 93117.

Aile, Çalışma ve Sosyal Hizmetler Bakanlığı (2020). https://www.ailevecalisma.gov.tr/tr-TR/haberler, Access date: 19.11.2020.

Akca, M. \& M. Tepe Küçükoğlu (2020). Covid-19 ve İş Yaşamına Etkileri: Evden Çalışma, Journal of International Management, Educational and Economics Perspectives, 8 (1)7181.

Arslan, İ. \& Bayar, İ. (2020), Covid-19 Salgını, Ekonomik Etkileri ve Küresel Ekonominin Geleceği, Gaziantep Unıversity Journal of Socıal Scıences, 2020 Specıal Issue, 87-104.

Birgün (08.03.2020), Salgın Döneminde Yoksula ve İşçiye Verilen Destek Yeterli mi? Sosyal Koruma Kalkanı Gerçekleri, https://www.birgun.net/haber/salgindoneminde-yoksula-ve-isciye-verilen-destek-yeterli-mi-sosyal-koruma-kalkanigercekleri-310519, Access Date: 18.12.2020.

Birgün (28.03.2020), Erkek Şiddeti Artıyor Devletin Bir Kriz Planı Yok, https://www.birgun.net/haber/erkek-siddeti-artiyor-devletin-bir-kriz-planiyok-293605, Access Date: 18.12.2020.

Birgün (01.04.2020), Yardım Kampanyalarını Tekellerine Aldılar, https://www.birgun.net/haber/yardim-kampanyalarini-tekellerine-aldilar294133, Access Date: 18.12.2020.

Birgün (07.04.2020), Korona Tedbirleri Kapsaminda Evsizlere Konaklama Projesi Başlatıld1, https://www.birgun.net/haber/koronavirus-tedbirleri-kapsamindaevsizlere-konaklama-projesi-baslatildi-295179, Access Date: 18.12.2020.

Birgün (14.04.2020), Sosyal Yardımlarda Büyük Muamma, https://www.birgun.net/haber/sosyal-yardimlarda-buyuk-muamma-296359, Access Date: 18.12.2020.

Birgün (22.04.2020), Halka Uzak Olursanız Hukuka da Uzak Kalırsınız, https://www.birgun.net/haber/halka-uzak-olursaniz-hukuka-da-uzakkalirsiniz-297653, Access Date: 18.12.2020.

Birgün (16.09.2020), Tasarruf Halka Yapılan Yardımlardan: Halka 1.3 Milyar, Müteahhide 1,6 Milyar TL, https://www.birgun.net/haber/tasarruf-halka-yapilanyardimdan-halka-1-3-milyar-muteahhite-1-6-milyar-tl-315758, Access Date: 18.12.2020.

Birinci, M. \& Bulut, T. (2020). Covid-19'un Sosyo-Ekonomik Yönden Dezavantajlı Gruplar Üzerindeki Etkileri: Sosyal Hizmet Bakış Açısından Bir Değerlendirme, Sosyal Çalışma Dergisi, 4 (1), 62-68.

Börke, T. Ç. (2020). Covid-19 Pandemisinin Ekonomik Büyüme Üzerindeki Etkisi. D. Demirbaş, V.Bozkurt \& S. Yorğun (Ed.), Covid-19 Pandemisinin Ekonomik, Toplumsal ve Siyasal Etkileri (pp. 25-34), İstanbul Üniversitesi Yayınevi.

Cantekin Ö. F. \& Arpacı, F. (2020). Covid-19 (Koronavirüs) Pandemisi ve Sosyal Hizmet, Uluslararası Sosyal Araştırmalar Dergisi, 13/73, 1138-1145.

Cumhuriyet (04.04.2020), Yokluk Virüs Kadar Y1kıc1, https:/ / www.cumhuriyet.com.tr/haber/yokluk-virus-kadar-yakici1731126, Access Date: 18.12.2020. 
Cumhuriyet (07.04.2020), Bakan Selçuk: Evsizlere Konaklama Projesi Başlatıldı, https://www.cumhuriyet.com.tr/haber/bakan-selcuk-evsizlerekonaklama-projesi-baslatildi-1731684, Access Date: 18.12.2020.

Cumhuriyet (06.08.2020), Pandemi Dönemi, https:// www.cumhuriyet.com.tr/yazarlar/olaylar-ve-gorusler/pandemidonemi-burhanettin-bulut-1756391, Access Date: 18.12.2020.

Cumhuriyet (07.07.2020), Sosyal Yardım Alanlar Dikkat! Zam Yapıldı, https:/ / www.cumhuriyet.com.tr/haber/sosyal-yardim-alanlar-dikkatzam-yapildi-1749927, Access Date: 18.12.2020.

Çetin, H. (2014). Türkiye'de Sosyal Hizmetler ve Sosyal Yardımlarm Yeniden Yapılanması Üzerine Bir Değerlendirme (Unpublished doctoral dissertation), Hacettepe Üniversitesi Sosyal Bilimler Enstitüsü Sosyal Hizmet Anabilim Dalı Doktora Programi.

Dafuleya, G. (2020). Social a nd Emergency Assistance Ex-Ante and During Covid-19 in the SADC Region, The International Journal of Community and Social Development, 2(2), 251-268.

Demirbaş, D. \& İncekara, A. (2020). Blokzincir ve Covid-19 Küresel Salgın İlişkisi. D. Demirbaş, V.Bozkurt \& S. Yorğun (Ed.), COVID-19 Pandemisinin Ekonomik, Toplumsal ve Siyasal Etkileri (pp. 53-68). İstanbul Üniversitesi Yayınevi.

Dilik, S. (1980). Sosyal Güvenlik ve Sosyal Hizmetler Arasındaki İlişkiler, Ankara Üniversitesi SBF Dergisi, 35/1, 73-84.

Dönmez Kara, C.Ö. (2020), Sosyal Politika Bağlamında Engellilere Yönelik Hizmetlerin Çanakkale Belediyesi Örneğinde Analizi, Yönetim ve Ekonomi Araştırmalan Dergisi, 18/1, 249-275.

Ersöz, H. Y. (2005), Sosyal Politika- Refah Devleti- Yerel Yönetimler İlişkisi, İ.Ü. İktisat Fakültesi Mecmuası, 55 (1): 759-775.

Faturahman, B. M. \& Harefa, M. (2020). Government Efforts in Anticipating Retardation of Economic Growth in 2020, Economic and Public Policy Division Info Singkat A Brief Study of Actual and Strategic Issues, XII.(10), 19-24.

Gelb, A. \& Mukherjee, A. (2020). Digital Technology in Social Assistance Transfers for Covid-19 Relief: Lessons from Selected Cases, Center for Global Development Policy Paper 181.

Gencer, N. (2020). Kovid-19 Sürecinde Yaşlı Olmak: 65 Yaş ve Üstü Vatandaşlar İçin Uygulanan Sokağa Çıkma Yasağı Üzerine Değerlendirmeler Ve Manevi Sosyal Hizmet, Türkiye Sosyal Hizmet Araştırmalan Dergisi, 4 (1), 35-42.

Gören, Z. (1997). Sosyal Devlet İlkesi ve Anayasa Hukuku Açısından Yaşam Kalitesi, Anayasa Yargisı 14. Ankara: Anayasa Mahkemesi Yayınları.

Güçlü, İ. (2019). Sosyal Bilimlerde Nitel araştırma Yöntemleri Teknik-YaklaşımUygulama. Ankara: Nobel Yayıncilik.

Gül, S. S. (2000). Yeni Sağ Sosyal Güvenlik Anlatışının Tarihsel Bağlantıları: İngiltere ve Türkiye Örnekleri, Ankara Üniversitesi DTCF Dergisi, 40, 3-4, 51-66.

Güler, B. A. (2006). Sosyal Devlet ve Yerelleşme, Memleket Siyaset Yönetim, 2006/2, 29-43.

Güler, A., Halıcıoğlu, B. M. \& Taşğın, S. (2015).Sosyal Bilimlerde Nitel Araştırma, Ankara: 2. Bask1, Seçkin Yayıncılık.

Gürbüz S. \& F. Şahin (2018). Sosyal Bilimlerde Araştırma YöntemleriFelsefe-Yöntem-Analiz. Ankara: Seçkin Yayınları, 5. Baskı. 
Hürriyet (03.03.2020), Bakanlık Duyurdu 1 Milyon Kişinin Yardımına Koştular, https:/ / www.hurriyet.com.tr/gundem/bakanlik-duyurdu-1-milyonkisinin-yardimina-kostular-41485744, Access Date: 18.12.2020.

Hürriyet (16.04.2020), Bakan Zehra Zümrüt Selçuk: İkinci 1000 TL Ödeme Haftaya Başlayacak, https://www.hurriyet.com.tr/ekonomi/bakan-zehrazumrut-selcuk-ikinci-1000-lira-odeme-haftaya-baslayacak-41496576, Access Date: 18.12.2020.

Hürriyet (18.06.2020), Dezavantajlı Gençlere Sosyal Koruma Kalkanı, https:/ / www.hurriyet.com.tr/ekonomi/dezavantajli-genclere-sosyalkoruma-kalkani-41544613, Access Date: 18.12.2020.

Kara, E. (2020). Covid-19 Pandemisi: İşgücü Üzerindeki Etkileri ve İstihdam Tedbirleri, Avrasya Sosyal ve Ekonomi Araştırmaları Dergisi (ASEAD), 7 (5), 269-282.

Kara, E. (2020). Kovid-19 Pandemisindeki Dezavantajlı Gruplar ve Sosyal Hizmet İşgücünün İşlevi, Türkiye Sosyal Hizmet Araştırmaları Dergisi, 4 (1), 28-34.

ILO (2020). Financing Gaps in Social Protection, https://www.ilo.org/ankara/areas-ofwork/COVID-19/WCMS755671/lang--tr/index.htm, Access Date: 19.11.2020.

İpek, M. (2015). Yeni Yoksulluk ve Türkiye'de Sosyal Yardım Paradoksu, Karatahta / Iş̧ Yazıları Dergisi, 1-Nisan, 77-104.

Islam T., Talukder, A. K. \& Siddiqui, N. (2020). Tackling the COVID-19 Pandemic: The Bangladesh Perspective, Journal of Public Health Research, 9: 1794, 389-397.

Lu, Q., Cai, Z. \& Chen, B. (2020). Social Policy Responses to the Covid-19 Crisis in China in 2020, International Journal of Environmental Research and Public Health, 17 (16), 5896, https://www.mdpi.com/1660-4601/17/16/5896, Access Date: 20.11.2020.

Lustig, N., Martinez P. V., Sanz, F. \& Younger, S. D. (2020). The Impact of Covid-19 Lockdowns and Expanded Social Assistance on Inequality, Poverty and Mobility in Argentina, Brazil, Colombia and Mexico, Centre for Global Development Working Paper 556, October, www.cgdev.org, Access Date: 25.11.2020.

Merriam, B. S. (2013). Nitel Araştırma Desen ve Uygulama İçin Bir Rehber. Turan, S. (Çev. Edt.), Ankara: Nobel Akademik Yayıncılık Eğitim Danışmanlık.

Sabah (30.03.2020), Başkan Erdoğan 7 aylık maaşını bağışladı. İşte Milli Dayanışma kampanyası hesap numaraları..., https://www.sabah.com.tr/gundem/2020/03/30/coronavirus-ile-mucadeledemilli-dayanisma-kampanyasi-basladi-baskan-erdogan-7-aylik-maasimibagisliyorum, Access Date: 18.12.2020.Sabah (04.04.2020), “Sosyal Yardımlar Eve Teslim", https://www.sabah.com.tr/ekonomi/2020/04/04/sosyal-yardimlareve-teslim,

Sabah (11.04.2020), Bakan Selçuk: Kadınlara Ödenen Sosyal Yardım Miktarı Arttırıldı, https://www.sabah.com.tr/ekonomi/2020/04/11/son-dakika-bakanselcuk-kadinlara-odenen-miktar-artirildi, Access Date: 18.12.2020.

Sabah (15.10.2020), Bakan Selçuk duyurdu: 40 Milyarlık Destek Sağlandı, https://www.sabah.com.tr/ekonomi/2020/10/15/bakan-selcukduyurdu-40-milyarlik-destek-saglandi, Access Date: 18.12.2020.

Sözcü (12.04.2020), Virüsün Çabasına Gerek Yok Bu Zihniyet Varken Biz Bize Yeteriz Türkiye'm, https://www.sozcu.com.tr/2020/yazarlar/yilmaz- 
ozdil/virusun-cabasina-gerek-yok-bizi-bu-zihniyet-yonetirken-biz-bizeyeteriz-turkiyem-5742349/, Access Date: 18.12.2020.

Sözcü (14.04.2020), Uğur Dündar ve Yılmaz Özdil Gündemi Değerlendirdi: Kolonyadan Ses Seda Yok, https:/ / www.sozcu.com.tr/2020/gundem/ugur-dundar-ve-yilmazozdil-gundemi-degerlendirdi-kolonyadan-ses-seda-yok-5748318/, Access Date: 18.12 .2020 .

Sözcü (14.05.2020), Paralar Nereye Gitti?, https://www.sozcu.com.tr/2020/yazarlar/emin-colasan/paralar-nereyegitti-5813104/, Access Date: 18.12.2020.

Taşçı, Faruk (2008). Yoksulluk ve Sosyal Hizmet. İstanbul Üniversitesi Açık ve Uzaktan Eğitim Fakültesi.

Taşcl, F. (2008). Türkiye'nin Kamusal Sosyal Yardım Anlayışı (1980-2007) Üzerine Bir Analiz, Sosyal Siyaset Konferanslarn Dergisi, 127-149.

T.C. Sağlık BAkanı̆̆1 (2020), Covid-19 Nedir?, https://covid19.saglik.gov.tr/TR66300/covid-19-nedir-

.html\#: :text=Yeni\%20Koronavir\%C3\%BCs\%20Hastal\%C4\%B1\%C4\%9F\%C4\%B1 \%20(COVID\%2D19,2020'de\%20tan\%C4\%B1mlanan\%20bir\%20vir\%C3\%BCst\%C3 \%BCr., Access Date: 25.12.2020.

TDK (2020), https:/ / sozluk.gov.tr/, Erişim Tarihi: 25.12.2020.

Türkiye (24.03.2020), Sosyal Yardımlaşma ve Dayanışma Vakıflarına aylık aktarılan kaynak 180 milyon çıarıldı, https://www.turkiyegazetesi.com.tr/ekonomi/690602.aspx, Access Date: 18.12.2020.

Türkiye (07.05.2020), Covid-19 Pandemisi Sürecinde Kadınlara Barınma Hizmeti, https://www.turkiyegazetesi.com.tr/gundem/702231.aspx, Access Date: 18.12.2020.

Ustaoğlu, M. (2020). Covid-19 Küresel Salgını ve Maliye Politikalarının Etkinliği, COVID19 Pandemisinin Ekonomik, Toplumsal ve Siyasal Etkileri içinde (ss. 35-52). (Ed: D. Demirbaş, V.Bozkurt, S. Yorğun), İstanbul Üniversitesi Yayınevi.

World Bank (2020). The impact of Covid-19 on Global Poverty Under Worsening Growth and İnequality, https:// blogs.worldbank.org/opendata/impact-COVID-19global-poverty-under-worsening-growth-and-inequality, Access Date: 19.11.2020.

Worldometers (2020). https://www.worldometers.info/coronavirus/\#countries, Access Date: 27.11.2020.

Yanık, C. \% Kara, M. (2014), Küreselleşmenin Sosyal Devlet Anlayışındaki Dönüşüme Etkisi: Genel Bir Değerlendirme, Emek ve Toplum, Cilt: 3, Yıl: 3, Sayı: 6, 9-25.

Yavuz, K. (2020). Covid-19 Salgınının Sosyal Politikanın Geleceği Üzerine Etkileri", Akademik Sosyal Araştırmalar Dergisi, 7 (45), 181-193.

Yeni Akit (01.08.2020), Bakan Zehra Zümrüt Selçuk: 'Biz Bize Yeteriz Türkiye'm Kampanyasında 1.2 Milyon İhtiyaç Sahibi Haneye Ulaşıldı, https://www.aa.com.tr/tr/ekonomi/bakan-zehra-zumrut-selcuk-bizbize-yeteriz-turkiyem-kampanyasinda-1-2-milyon-ihtiyac-sahibi-haneyeulasildi/1928822, Access Date: 18.12.2020. 
Yeni Akit (11.10.2020), Kovid-19 Salgınında 65 Kamu Tesisi Mağdur Kadınların Hizmetine Sunuldu, https://www.yeniakit.com.tr/haber/kovid-19salgininda-65-kamu-tesisi-magdur-kadinlarin-hizmetine-sunuldu1410729.html, Access Date: 18.12.2020.

Yıldırım, A. \& Şimşek, H. (2016). Sosyal Bilimlerde Nitel Araştırma Yöntemleri. Ankara: Seçkin Yayıncılık, 10. Baski.

Yılmaz, A., Aksanyar, Y., \& Güler T. (2018). Sosyal Yardım Olgusu ve Türkiye'de Şartlı Sosyal Yardım Uygulamaları, EKEV Akademi Dergisi, Yıl: 22 Sayı: 73- Kış, 595-612.

Yorğun, S. (2020). Covid-19 Salgının Sosyal Politikalara Etkileri. Demirbaş D., Bozkurt, V. \&Yorğun, S. (Ed.), Covid-19 Pandemisinin Ekonomik, Toplumsal ve Siyasal Etkileri (pp. 99-114). İstanbul Üniversitesi Yayınevi.

Yüksel, S. (2020). Çalışma Hayatında Koronavirüs (Covid-19) Salgınının Etkileri, İstanbul Ticaret Üniversitesi Sosyal Bilimler Dergisi Covid-19 Hukuk Özel Sayısı, Y11:19 Sayı:38 Yaz 2020/2, 34-61.

Zengin E., Şahin A. \& Özcan S. (2012). Türkiye'de Sosyal Yardım Uygulamaları, Yönetim ve Ekonomi Dergisi, 19/2, 133-142.

https://www.maxqda.com/help-mx20/maxmaps/two-case-model, Access Date: 10.10.2020. 


\title{
Chapter 3
}

\section{The Status of the Retail Sector During and After the Covid-19 Outbreak: What Should Strategic Managers Do?}

\author{
Huseyin Guven, Emine Turkan Ayvaz Guven, Bulent Akkaya
}

\begin{abstract}
The coronavirus epidemic, which emerged in China and affected the whole world, caused the world economy to shrink in addition to the health problems it caused. The Covid-19 outbreak has begun to transform businesses and the economy along with human behavior all over the world. Retail sector is one of the sectors that deeply feel the negative reflections of the epidemic. The strategic managers of the businesses had to change their business plans due to the closure of the stores and the retreat of the customers to their homes due to the epidemic. Customers who follow governments' calls to stay home have started to turn to e-commerce instead of retail shopping. This epidemic will of course end in the future. However, in the world that has changed due to the epidemic, nothing will be the same as before. Businesses that want to find a place in the market in the new process have to make some innovations in order to adapt to this new process. In line with all these, this study will explain the developments in the retail sector during the Covid19 period and after the Covid-19 outbreak, the strategic managers of businesses that want to adapt to the new process will be informed about the applications they can do.
\end{abstract}

Keywords: Covid-19, Outbreak, Retail Industry, Strategic Management, Digital Technologies 


\section{INTRODUCTION}

The epidemic caused by the virus called Covid-19, which emerged in Wuhan, within the borders of China in late 2019, has gained a global feature in a very short time despite all the measures taken. As of December 15, the virus infected more than 70 million people in 187 countries, causing nearly 1 million 600 thousand people to die (WHO, 2020). In order to relieve the unprecedented pressure that the epidemic has put on the health systems of countries and to reduce deaths, the authorities have taken emergency measures. Quarantine measures, curfews, and massive restrictions on movement of goods and people have brought the global economy to a standstill. Serious deadlocks occurred in the post-coronavirus economies, which led to a decrease in production and consumption. In general, the functioning of global supply chains has been disrupted, and all companies in the world have been negatively affected by this situation (Cinel, 2020).

In the Pricewaterhouse (2020) report, among the sectors that will be most affected by mobility restrictions and entry and exit bans; Air transport, travel agency activities, retail, entertainment, accommodation, restaurant services, sports and entertainment. In particular, the Covid-19 outbreak has had different effects in different situations in the retail industry (Dunlap, Wagner \& Scavo, 2020). Considering the economic impact of the coronavirus epidemic on public health, it is striking that the emergency measures to be taken in this context are quite high, especially in the retail sector. Due to the rapid spread of the coronavirus, the closure of shopping centers and stores has significantly affected the retail industry. Munbodth (2020) says that 20,000 high street retail stores across the UK alone will have to withdraw from the market due to the pandemic. Therefore, it is clear that the process concerns not only large enterprises, but also all local and global enterprises. The current situation creates great difficulties especially for the non-food retail sector, which derives a significant part of their turnover from customer traffic. It has become important to take measures both in-store and outside the store in order to solve the problems that occur in the supply chain, human resources and store operations and to make a healthy transition to the post-epidemic process (Deleoitte, 2020). In line with all these, the purpose of this study is to provide information about the developments in the retail sector during the Covid-19 process and to provide information about the applications that can be done to the strategic managers of the enterprises that want to adapt to the new process after Covid-19.

\section{BACKGROUND}

\section{What Is Retailing?}

The retailing sector is one of the leading industries for the economies of the countries, which has been continuously developing with the economic growth and the development of new technologies in recent years. The share and importance of retailing in the global and national economy is increasing day by day. The foundations of the concept of retailing date back to ancient times. In addition, retailing appears as a concept and practice as old as commerce itself (Sullivan \& Addock, 2002). Retail markets and shops have a very old history dating back to earlier times. Some of the oldest retailers appear as mobile peddlers. Day by day, retail stores have turned into sophisticated shopping centers (Genç, 2019).

Retailing is the last link of the distribution chain between consumers and producers. In its simplest form, retailing is the line of activity that comes into play during the purchase and 
consumption of goods and services (Arıkbay, 1996). The retailing sector, which increases its development day by day, has shown important developments in meeting the preferences of customers more. Retail organizations structured to meet the needs of each customer have important functions as well as being the last link of the marketing network (Atikeller, 2008). The retail industry offers a structure that is extremely lively, open to innovations and in regular transformation. It is one of the areas where developments and consumer trends are directly and most felt. The retailing industry is a sector that has started to take place more and more in daily life with the breakthroughs brought by globalization, and includes items whose share in annual consumption expenditures does not decrease. The retail sector, which grew behind the average in the world economy in 10 years after the 2009 crisis, achieved a growth of 5 percent in 2019. The size, which reached 25 trillion dollars globally last year, is estimated to exceed 30 trillion dollars in 2023 (KPMG, 2020).

Retailers have a commercial organization that generally performs their sales as retail. In addition, the number of retailers who do not own a store is increasing day by day. The direction of competition in the field of retailing is increasingly dependent on both "being bigger" and "using technology (internet, mobile etc.) well". In other words, retailing is transforming into e-retailing (Gülşen \& Özdemir, 2019). Enterprises trying to gain an advantage in today's competitive conditions have to follow technological developments and include technological innovations in their business activities. At the same time, it is becoming more and more important to evaluate the advantages of technology in marketing efforts against the customer mass whose demands and expectations change and diversify.

\section{EFFECTS OF COVID-19 ON RETAIL SECTOR}

With the outbreak of COVID-19, many changes have occurred in the world, and many sectors have been adversely affected by this situation. This crisis, which gradually affects our lives, continues to have negative effects on employees and businesses with its socio-economic effects (Tunç \& Yetkin, 2020). Key sectors that make up almost a quarter of the country's GDP, such as transportation, entertainment, retail, hotels and restaurants, have suffered seriously (Cinel, 2020). The most affected of these is the retail sector. Almost everywhere in the world, the quarantine of people and the shifting of their consumption habits to online channels put retailers through a tough test. The retail industry, which makes a great effort to respond to consumer demands, is trying to adapt to the new era. In many parts of the world, most of the stores have been closed and the number of customers in the open stores has started to decrease gradually. Therefore, the supply chain of retail stores has deteriorated significantly. Throughout this fluctuating economic environment, organizations are often under pressure to continue their operations, plan a new future, and most importantly, optimize costs (Sayegh, 2020).

In the process of Covid-19, people need to isolate themselves at home and reduce physical contact to prevent getting sick. In such a situation, businesses need to pay more attention to rapidly developing and strengthening their online business with marketing innovations (Wang et al., 2020). During the crisis and home isolation, a new area of retail, online shopping, has been on the rise. Traditional retailers must set their priorities as soon as possible and find new ways to integrate e-commerce into their systems. Due to the difficulties in the use of modern technology and the preference of choosing fresh food products individually, the consumer segment that preferred traditional shopping had to resort to modern trading methods based on online shopping. After the epidemic, experts predict that this commercial behavior pattern will continue. 
In this sense, companies need to understand consumer needs and fears and adapt their products and distribution systems. In this way, new consumption restrictions will be reduced and the sales action will be facilitated. Companies with elements such as quality and efficiency, local production, and the ability to adopt new retail technologies can persuade consumers and create customer loyalty in the post-pandemic period (Stanciu et al., 2020). Brands that can gain the trust of their customers during the Covid-19 crisis stand out. From now on, it is important to focus on what the consumer wants by going to the basis of retailing. For this, a customer-oriented service and marketing methods should be developed.

In order to get out of this process with minimum damage or to evaluate the opportunities that may arise, companies need to create a roadmap and take action in line with their own strategy. Strategic managers of the retail sector should make some regulations in terms of hygiene practices in order to attract customers back to the store and organize campaigns that will return customers to their stores. However, managers should make technology and innovation-based system and method changes to prevent loss of sales due to increased consumer sensitivity. Applications that can be done within this scope are explained in detail below.

\section{WHAT SHOULD STRATEGIC MANAGERS DO?}

\section{Measures to be Taken within the Scope of Store Cleaning and Employee Safety}

During the epidemic period, it has become a necessity to take hygiene measures within the store in order to attract customers back to the stores. According to the research conducted by Xsights Research and Consultancy Company, consumers stated that they would not visit the stores that did not take adequate measures. However, consumers have reported that they will spend less time in the store than in the past (Xsights, 2020). Shahbaz et al. (2020), in a study examining the effects of coronavirus in food services and retail industry, it was concluded that in order to reduce the possible spread of the epidemic in the retail sector, attention should be paid to hand hygiene, use of disinfectants, and social distance rules in businesses and interactions with customers. It was also stated that in order to avoid the further spread of the coronavirus, the body temperature of both staff and incoming guests should be monitored in order to determine whether there is a sick person. The strategies of many retailers in the UK affected by the Covid-19 pandemic process for the current crisis situation; reducing their presentation on the shelves, offering the most essential products, preparing shelves, keeping stores clean, and reducing operational pressures. In addition, more employees were assigned to increase cleanliness throughout all operations; Free hand cleaning was offered in order to eliminate the security concerns of customers coming to the stores; By limiting the number of customers in stores, social distance has been provided; The contactless card limit has been increased and communication was limited by arranging protective screens (Sharma et al. 2020).

The changing working conditions after the epidemic bring new risks to the agenda in the field of occupational health and safety. It is very important to communicate with different stakeholder groups through various channels and to provide awareness-raising information about epidemic preparedness and combat. The stakeholder group that is aimed to create the most change should be the employees. Providing employees with informative content on epidemic preparedness and combating pandemic for both private and business life will increase performance at the point of adoption and implementation of the subject.

\section{Measures to be Taken within the Scope of Store Layout}


During the epidemic period, customers do not want to spend much time in stores. Therefore, it has become important to take measures to ensure that customers spend less time in stores. It is necessary to optimize your store layout for a fast entry and exit. Because after Covid-19, consumers demand experience of shopping with less physical contact and less contact with people. They will probably want to continue this situation after the epidemic. In order to achieve this, strategic managers of businesses should provide more creative window designs to attract customers to the store and enable them to shop, and create a richer customer experience, a flawless, neat and clean store layout to keep customers in. It is critical in this process to provide abundant information about products in online channels and to convey product features by the personnel in a shorter time.

Measures to improve the process are important, as customers visiting the stores will pay attention to social distance at the point of payment and contactless payment opportunities. Customers can purchase their products at the cash register with a $\mathrm{QR}$ code on their mobile phone and pay at the digital cash registers without contacting anyone. The increased safety of customers and store staff, no queues or contact with other people will reassure everyone. Measures related to this have started to increase day by day. Supermarket chain Aldi, for example, has launched an "automatic traffic light system" in its UK stores to ensure that social distancing measures continue. Depending on the size and layout of the store, each has a certain number of customers they can allow at a time to provide a distance of two meters. The traffic light system monitors customers entering and leaving the store. The light turns red and only turns green when there is enough space in the store for the next customer to enter safely (Springwise, 2020). Another example can be given to applications that can be done to accelerate the process of shopping is the Mkolay application developed by Migros in Turkey. The application allows customers to shop in physical stores using their smart phones. While consumers are shopping in the store, they can scan the barcodes of the products into the MKolay application on their mobile phones and make payments in 30 seconds from jet cash registers.

\section{Precautions to be Taken within the Scope of Technological Applications}

In the protracted global economic crisis, the need to innovate has been critical for retailers and manufacturers (Shankar et al., 2011). In the Covid-19 Process, it has become a necessity for retailers to make technology and innovation-based system and method changes in order to prevent loss of sales due to the increased sensitivity of consumers. Especially in crises with unpredictable outcomes such as epidemics and with an unstable behavior pattern, radical changes are expected. Rapid adaptation to changing conditions is of great importance in today's world. The way to be fast can only be achieved with technology (Escarus, 2020).

Technological and industrial developments play a very important role in achieving environmental, economic and social sustainability goals. For this reason, businesses, in order to achieve sustainable growth and improve sustainability at a more general level, the tools and opportunities related to Industry 4.0; It must be able to use it effectively in shaping its organizations, strategies, policies and operations. Especially in the process of combating the global epidemic, the ability of companies to use these technologies is an indicator of determining the current level of digitalization, but also sets an example for businesses that do not have these technologies, showing the advantages or disadvantages of these technologies.

Robotic technologies are one of the areas where technological change is expected to occur most in the post-epidemic period. Robots have transformed some industries technologically by taking the responsibility of blue-collar workers in many developed sectors. With the integration of 
decision support software and artificial intelligence applications into existing systems, this transformation has now begun to affect white-collar workers. After the epidemic, especially pharmacy, consumer banking, retail, etc. It is estimated that robots and artificial intelligence solutions will appear more in professions (Escarus, 2020). It is predicted that artificial intelligence will change our world more than most people think today. Artificial intelligence provides machines with the power to see, hear, taste, smell, touch, speak, walk, fly and learn. This means businesses can develop entirely new ways to interact with their customers, provide them with smarter products and service experiences, automate processes, and improve business performance (Marr \& Ward, 2019).

The impact of the artificial intelligence technology revolution on the consumer is particularly significant. In recent years, there has been a large customer transition from the physical location customer profile to the cyber space. Artificial intelligence applications have a great impact on consumer and consumer behavior that has moved to digital. The corporate analytical intelligence support needed to restructure managerial and operational processes and develop innovative products and services is provided by artificial intelligence (Büyükuslu, 2020).

Artificial intelligence systems are trained on large data sets to learn. Therefore, retail environments are a fertile ground for the use and development of artificial intelligence. Retailers invest in multiple AI applications to take advantage of rapidly developing big data. By 2022, retailers' AI spending is estimated to be $\$ 6$ billion (Shankar, 2018).

Retail businesses can benefit from the capabilities of artificial intelligence to understand, predict, analyze consumer behavior and make advanced decisions, especially in the Covid-19 process. In a discussion on the subject, the BBC (2020) specifically regarding the global epidemic period we are in, "Will Covid-19 accelerate the use of robotic systems instead of human workers?" included the question. According to this news; Most experts state that the current process will accelerate the spread of robotic applications. Also in the news; It has been stated that the world retail giant Walmart has started to use robots in floor cleaning, and South Korea uses robots in measuring the fire of people and distributing disinfectants. In addition, it is seen that fast-food chains such as food retailer McDonald's have started to test robots as cooks. It has been stated that many companies want to increase the use of robots for sorting, shipping and packaging, as in warehouses operated by retail businesses such as Amazon and Walmart (BBC, 2020).

Considering many business models in different sectors, developments in smart automation are expected to significantly reduce the transaction costs of institutions. At this point, it may be possible to make new purchases with the earnings to be made. The use of service robots in the health, hospitality and retail sector not only reduces costs but also increases efficiency. In the postepidemic period, it is predicted that robots will work more in jobs that are considered risky for humans (Escarus, 2020).

Another area where artificial intelligence can be useful is in customer service. Chatbots, which provide communication with artificial intelligence, audio / voice or textual methods, provide retailers with benefits that increase both productivity and satisfaction in the customer service experience on "chatbots" platforms. Retailers working 24 hours a day, every day of the week, can provide a strong customer experience by eliminating waiting times through this system (Shankar, 2018)

With the global epidemic, people's closure to their homes and their complete or partial isolation from both social and business life makes it important to be connected at all times in order for the current order to function smoothly. Therefore, remote access technologies are gaining popularity in such a period (Yiğitol \& Sarı, 2020). Another concept that retail managers can benefit from in this process is the concept of the internet of things. The Internet of Things refers to smart objects 
(things) that can seamlessly connect, share data, information, and react to changes in the environment (Zawra, et al., 2017).

According to Vodafone's IoT Spotlight 2020 research, which examines the changes in business processes of businesses during the pandemic process and how they are prepared for the future, the importance of the Internet of Things is expected to increase gradually. While 87 percent of the enterprises participating in the research said that the most important factor in their future success will be the Internet of Things; 82 percent of the enterprises stated that they increased their revenues after using the Internet of Things, and 81 percent stated that they increased their market shares. 77 percent of the enterprises stated that they are accelerating their Internet of Things (IoT) projects. (Haberturk, 2020). Retailers can benefit from the Internet of Things in product-goods tracking, customer interaction and optimization of customer experience, creating smart business infrastructure, monitoring customer behavior, mobile payment systems, in-store inventory management, and optimizing business and human resources (Innova, 2015).

In the Covid-19 process, managers of the retail industry must be prepared to run flexible operations. In this process, stocks are running out as new developments deeply shake the supply chain. That's why retailers need to invest in flexibility and speed when planning for the future. At this point, it is important to give weight to automation and to ensure uninterrupted flow of information. Office automation refers to the use of computer technology in offices in order to carry out work and transactions in offices more efficiently and quickly (Altınöz, 2008). These systems include invoicing, order, stock, logistics, etc. are operational structures used in operational processes. Although there is an office phrase in its name, it is predicted that most of these systems will be remotely managed and accessible after the epidemic. With office automation and intranet applications, organizations will virtualize many processes such as education, human resources, accounting and finance (Escarus, 2020).

Virtual reality applications are one of the technological applications that can be used in the Covid19 process. In virtual reality, users can physically walk around objects and perceive objects as if they were real (Jerald, 2016). Virtual shopping environments are also a type of virtual reality. In these purchases, consumers can shop without waiting in the checkout queue, without touching the grocery cart and without searching for a car park. With the virtual shopping method, faster shopping can be achieved by providing transitions between shelves and aisles in the virtual store (Cox et al., 2004). Porter et al. (2017) according to, virtual reality will redefine the concept of showroom and product promotion and turn it into a customer experience. When customers understand how a product looks and functions in a real environment before purchasing it, they will have more precise expectations, more comfortable purchasing decisions and higher product satisfaction. Recently, augmented reality technology may also reduce the need for physical stores and showrooms. The application of a bridal dress company operating in Spain can be given as an example. The firm has developed a digital showroom application where customers can purchase their latest collections. The firm has also launched an e-service platform to exchange information with customers and advertised its products by virtual appointment. The company also carried out live webcasts on social media for product promotion (Springwise, 2020).

As quarantines were implemented and travel was restricted, the means of communication between buyers and suppliers have changed. The use of applications such as Skype, WhatsApp and Zoom has increased. However, the digital age of online, mobile and social media marketing has developed rapidly within weeks (He and Harris, 2020). At this point, social media brings along important information about the values of consumers. A tweet that a consumer sends about his social media posts, agenda or what he feels shows what he thinks, feels and how they convey 
their values. Therefore, businesses can be more effective by obtaining this information. Because understanding values is the basis of understanding consumer behavior (Lee and Kahle, 2019).

\section{SOLUTIONS AND RECOMMENDATIONS}

The Covid-19 outbreak, which has affected the whole world since December 2019, reshaped the sectors. However, this change, which affects our lives in some way, has been experienced much faster and radically in the retail sector. This epidemic, which occurred at an unexpected time, caused many businesses to be caught off guard. Many retail stores have closed and continue to close. Retail stores, which take their precautions during the process, overcome the process with the least damage. In such times, the role of a successful retail manager is to help the business, in which he is the manager, adapt agile to new conditions.

The first thing that retailers need to do in the process is to attract customers back to their stores. After the necessary precautions are taken, organizing communication campaigns to attract consumers back to the store can accelerate the return. For this purpose, distributing discount coupons and organizing discount campaigns is one of the applications that can be done. In addition, store-specific products can be useful in transforming retail stores into a point of attraction again.

With Covid-19, new strategies are needed to ensure continuity in issues such as employee health and consumer confidence. Strategic managers of the retail industry should make short or long term plans by considering different scenarios for the future. At the same time, in order to prevent the spread of Covid-19, businesses should be pioneers in issues such as hygiene and social awareness. It is important to ensure workplace safety and health for personnel who have to work compulsorily in this process.

One of the steps to be taken in the Covid-19 Process is to develop a model that takes digital to the fore. As the internet shopping trend is expected to continue to rise after this epidemic crisis, retailers should prioritize the internet shopping experience. With the initiation of investments in the field of online sales, preparations should also be made in the fields of logistics and stock management and long-term planning should be applied according to the needs. After the pandemic, improvements to focus on the supply chain and reinforce the supply chain are becoming a priority.

Technological innovations are constantly evolving in retail. Hence, retailers should also be interested in innovative business models created by technological innovations and apply them within their businesses. Retailers need to design digital procurement, digital products and services. In this period, it is important to get support from software and information technologies. In this context, it is recommended that enterprises develop applications that will provide digital transformation. In this way, it is important to communicate with consumers one-on-one. Based on corporate governance approaches; Providing digital interaction with consumers and making them a part of the entire system, creating virtual working models, developing data-based and real information-based strategies, focusing on collaboration and rapid decision-making, and adapting the most up-to-date technology will gain importance. In this context, businesses must be prepared for these changes. 


\section{FUTURE RESEARCH DIRECTIONS}

In this study, the developments that occurred in the retail sector during the Covid-19 period were explained, and in this direction, the strategic managers of the enterprises who want to adapt to the new process after the Covid-19 epidemic were informed about the applications they can do. In future research, studies can be conducted to evaluate the practices of different retail businesses that will set an example for other businesses in the Covid-19 process. The study was conducted on retail businesses that provide physical service. In the planned studies, an evaluation can be made about the measures to be taken and the applications that can be carried out by businesses serving in the e-commerce sector during the Covid-19 process.

\section{CONCLUSION}

Due to the quarantine measures taken, the Covid-19 Process had negative impacts especially on retail businesses that provide physical services. In this process, strategic managers of retail businesses should take some precautions to win customers who have moved away from their businesses due to Covid-19. In this sense, it is important to carry out studies that can prevent contact in the store layout and in the shopping process. In addition, managers of retail businesses should effectively use the tools and opportunities related to Industry 4.0 in shaping the organizations, strategies, policies and operations of the retail businesses they manage. 


\section{REFERENCES}

Altınöz, M. (2008). Ofis Otomasyonu Sistemlerinin Bireysel Performans Üzerine Etkisi. Selçuk Üniversitesi Sosyal Bilimler Enstitüsü Dergisi, 20: 51-63. https://doi.org/10.33905/bseusbed.474469

Arıkbay, C. (1996). Türkiye'de Perakendeciliğin Gelişimi. Ankara: MPM Yayınları.

Atikeller, G. (2008). Perakende Sektöründe Teknolojik Yenilikler ve Bir Araştırma. (Yayınlanmamış Doktora Tezi). Marmara Üniversitesi Sosyal Bilimler Enstitüsü, İstanbul.

BBC (2020, April 18). Coronavirus: Will Covid-19 Speed Up the Use of Robots to Replace Human Workers?. Retrived October 16, 2020, from https://www.bbc.com/news/technology52340651.

Büyükuslu, A.R. (2020). Koronavirüs Sonrası Yenidünya Düzeni Ekonomi-Devlet-Yapay Zekâ. İstanbul: Der Yayınevi.

Cinel, E. A. (2020). Covid-19' un Küresel Makroekonomik Etkileri ve Beklentiler. Politik Ekonomik Kuram. 4(1), 124-140. https://doi.org/10.30586/pek.748538

Cox, R. \& Brittain, P. (2004). Retailing an Introduction (5.Baskı). England: Pearson Education.

Dunlap, T., Wagner, D., \& Scavo, F. (2020). Coronavirus Impact Index by Industry. Retrieved 20 November, 2020, from https://www.computereconomics.com/article.cfm?id=2788.

Escarus (2020). Bir Eko-Sosyal Kriz Olarak Covid-19 Salgını ve Sürdürülebilirlik. Retrieved October 5, 2020, from http://www.escarus.com/i/content/512_2_Escarus_Bir_Eko Sosyal_Kriz_Olarak_Covid-19_Salgini_ve_Surdurulebilirlik_052020.pdf.

Genç, M. (2019). Perakende Sektöründe Mağaza Atmosferinin Müşteri Sadakati Üzerindeki Etkisi. (Yüksek Lisans Projesi). Maltepe Üniversitesi Sosyal Bilimler Enstitüsü, İstanbul.

Gülşen, İ. \& Özdemir, Ş . (2019). Mobil Teknolojinin Perakendecilik Üzerindeki Etkileri. Eskişehir Osmangazi Üniversitesi İktisadi ve İdari Bilimler Dergisi, 14 (2) , 421-440 . https://doi.org/10.17153/oguiibf.483661

HABERTURK (2020, October 19). İşletmeler Pandemi Sonrasına Nesnelerin İnterneti ile Hazırlaniyor. Retrieved 16 November, 2020, from https://www.haberturk.com/pandemi-sonrasina-nesnelerin-interneti-ilehazirlaniyorlar-haberler-2840638-teknoloji

He, H., \& Harris, L. (2020). The Impact of Covid-19 Pandemic on Corporate Social Responsibility and Marketing Philosophy. Journal of Business Research. 116: 176-182. https:// doi.org/10.1016/j.jbusres.2020.05.030

İNNOVA (2015, September 18). Nesnelerin İnterneti İle Perakende Sektöründe Yenilikçi Çözümler. $\quad$ Retrieved 10 November, 2020, from https://www.innova.com.tr/tr/blog/dijital-donusum-blog/nesnelerin-interneti-ileperakende-sektorunde-yenilikci-cozumler

Jerald, J. (2016). The VR Book: Human-Centered Design for Virtual Reality. The Association for Computing Machinery and Morgan \& Claypool Publishers Journal of Marketing, 69 (3), 152-168. https://doi.org/10.1145/2792790

KPMG (2020). Sektörel Bakış 2020- Perakende. Retrieved 15 October, 2020, from https://home.kpmg/tr/tr/home/gorusler/2020/01/sektorel-bakis-2020perakende.html. 
Lee, C., \& Kahle, L.R. (2019), "Social media and Values", Consumer Social Values, Edited by Eda Gürel and Lynn R. Kahle, Taylor \& Francis Group.

Marr, B. \& Ward, M. (2019). Artificial Intelligence in Practice: How 50 Successful Companies Used AI and Machine Learning to Solve Problems,. West Sussex: Wiley.

Munbodth, E. (2020, March 26). Coronavirus: 20,000 High Street Shops That Have Closed During Lockdown Will Never Reopen. Retrieved 01 November, 2020, from https://www.mirror.co.uk/money/ coronavirus-more-20000-shops-closed-21756815

Porter, M.E. \& Heppelmann, J. E. (2017). Why Every Organization Needs an Augmented Reality Strategy. Harvard Business Review, November- December

Pricewaterhouse Coopers (2020). Considering the Potential Business Impacts of the Covid-19 Outbreak. $\quad$ Retrieved 25 November, 2020, from https://www.pwc.com/m1/en/publications/covid-19/considering-the-potentialbusiness-impacts-covid-19-outbreak.pdf

Sayegh, E. (2020, March 26). As COVID-19 Pushes Businesses To Their Limit, The Cloud Rises Above. $\quad$ Retrieved 20 September, 2020, from https://www.forbes.com/sites/emilsayegh/2020/03/26/as-covid-19-pushesbusinesses-to-their-limit-the-cloud-rises-above/?sh=4a56f7447851

Shahbaz, M., Bilal, M., Moiz, A., Zubair, S., \& İqbal, H. (2020). Food Safety and COVID-19: Precautionary Measures to Limit the Spread of Coronavirus at Food Service and Retail Sector. Journal of Pure and Applied Microbiology, 14(Special Edition), 1-8. https://doi.org/10.22207/jpam.14.spl1.12

Shankar, V. \& Yadav, M.S. (2011). Innovations in Retailing. Journal of Retailing, $87 S$ (1), 1-2. https://doi.org/10.1016/j.jretai.2011.04.004

Shankar, V. (2018). How Artificial Intelligence (AI) Is Reshaping Retailing. Journal of Retailing, 94 (4), 5-11. https:// doi.org/10.1016/s0022-4359(18)30076-9

Sharma, P., Leung, T.Y., Kingshott, R.P., Davcik, N.S. \& Cardinali, S. (2020). Managing Uncertainty During a Global Pandemic: An International Business Perspective. Journal of Business Research, 116, 188-192. https:/ / doi.org/10.1016/j.jbusres.2020.05.026

SPRİNGWISE (2020, June 16). 7 Innovative Ideas For Brıck-And-Mortar Businesses Reopening After Lockdown. Retrieved 20 September, 2020, from https://www.springwise.com/innovation-snapshot/coronavirus-business-ideas-brickand-mortar-lockdown

Stanciu, S., Radu, R.I., Sapira, V., \& Dumitrache, B., (2020). Consumer Behavior in Crisis Situations- Research on the Effects of COVID-19 in Romania. Annals of Dunarea de Jos University of Galati, s.5-13. https:// doi.org/10.35219/eai1584040975

Sullivan, M., \& Adcock, A. (2002). Retail Marketing. London: Thomson.

Tunç, Ö., \& Yetkin, D. G. (2020). Covid-19 Kaynaklı Pandemi Döneminde Tüketici Davranışları: Perakendeci Markalı Ürünler Üzerine Bir Araştırma. Gaziantep University Journal of Social Sciences (Special İssue), 457-471. https://doi.org/10.21547/jss.784404

Wang, Y., Hong, A., Li, X. \& Gao, J. (2020). Marketing Innovations During a Global Crisis: A Study of China Firms' Response to COVID-19. Journal of Business Research, 116, 214-220. https://doi.org/10.1016/j.jbusres.2020.05.029

WHO (2020, December,15). Weekly Epidemiological Update. Retrieved 15 December, 2020, https://www.who.int/publications/m/item/weekly-epidemiological-update---15december-2020 
Retail Sector During and After the Covid-19 Outbreak: What Should Strategic Managers Do 58

XSİGHTS (2020, June 2). Pandemi Yaşamın Temellerini Yeniden Şekillendiriyor. Retrieved 18 August, 2020, from https://www.xsights.co.uk/tr/pandemi-yasamin-temelleriniyeniden-sekillendiriyor-9743/

Yiğitol, B. \& Sarı, T. (2020). Küresel Salgınlar ile Mücadelede Endüstri 4.0 Teknolojilerinin Rolü. Pamukkale Üniversitesi Sosyal Bilimler Enstitüsü Dergisi, 41, 53-73.

Zawra, L. M., Mansour, H. A., Eldin, A. T., \& Messiha, N. W. (2017). Utilizing the Internet of Things (IoT) Technologies in the Implementation of Industry 4.0. In International Conference on Advanced Intelligent (s. 798-808). Cham: Springer. 


\title{
Chapter 4
}

\section{Work-Life Balance During COVID-19 Pandemic and Remote Work: A Systematic Literature Review}

\author{
Helena Bulińska-Stangrecka, Anna Bagieńska, Anuradha Iddagoda
}

\begin{abstract}
The COVID-19 pandemic has caused many negative and drastic changes in contemporary organizations with regard to employees. Human resources management faces the challenge of developing ways to mitigate the negative effects of work during the pandemic. Factors such as feeling threatened, isolation, working from home or insecurity have all contributed to the well-being of employees. They pose a significant challenge for managers who need to adapt management tools to new realities. It is also necessary to ensure the well-being of employees in order to work efficiently. An important element that requires analysis and development of further support schemes is work-life balance. Remote working has caused an accumulation of professional activities in private places. The spatial boundary separating the workplace from the resting place has also been blurred. Additionally, due to the extension of working time at home, time limits have also changed. As a result, the work-life balance was disrupted, negatively affecting the mental health of employees. The systematic literature review in this chapter concerns the analysis includes an analysis of key research areas of work-life balance related to remote working. The study analyzes various aspects of the imbalance between home and work as well as the most acute effects of new forms of work introduced as a result of the pandemic.
\end{abstract}

Keywords: COVID-19, Work-life Balance, Remote Work, Well-being 


\section{INTRODUCTION}

Ensuring the proper work-life balance (WLB) is an important concern for contemporary organizations. Wood, Oh et al. (2020) point out that WLB is a topic of interest for both practitioners and researchers in relation to promoting employee well-being (Jones et al., 2013; Kinnunen et al., 2015; Wagner et al., 2014). Previous research had indicated that WLB has a positive impact on employees welling and positive energy at work (Russo, Shteigman \& Carmeli 2016). Moreover, it has been demonstrated that WLB is liked to job engagement and turnover intentions (Jaharuddin, Zainol 2019). In addition, research indicates that remote working and various forms of flexible employment allow WLB to be maintained (Chung, Lippe, 2020) and facilitate the development of a balance between private and professional life.

Until recently, however, remote working, although more and more common, was not the prevailing form of work arrangement. Despite the growing popularity of this solution, many organizations, such as Yahoo for example, have been withdrawing from implementing such measures (Felstead, Henseke, 2017). Changes in the sudden and widespread use of remote working were caused by restrictions implemented worldwide in connection with the COVID-19 pandemic in March 2020 (Ozimek, 2020).

For many employees, the increase in remote work, combined with the reduction of social mobility, means significant changes in the organization of their lives. Furthermore, studies to date show that one of the key challenges of remote working is to maintain WLB (Felstead, Henseke, 2017; Palumbo, 2020). Indeed, research suggests that remote working significantly disrupts WLB among employees (Muralidhar et al. 2020). Songsangyos and Iamamporn (2019) also point to the conflict of roles related to remote work and resulting from the need to combine different responsibilities in one physical space. Therefore, despite the many benefits, remote working often contributes to WLB disturbance. However, the need to implement such solutions requires a reflection on possible measures to mitigate the negative effects of remote working on WLB.

In this chapter, we present a systematic review of the literature on WLB. Although, we review the entirety of existing literature, we focus on the WLB in the context of and remote working. Our analysis allows us to diagnose key areas indicating the need for further empirical research on WLB issues in relation to remote working.

The main arguments and contributions we offer are: the identification of key areas contributing to improving WLB among remote workers and the analysis of critical fields requiring further study of the challenges of balancing work and private life in a remote working environment. The global spread of remote working associated with epidemiological restrictions contributes to the need to develop guidance on how to mitigate the negative effects of working from home on WLB.

This chapter is structured as follows: first we introduce the definitions and ways of conceptualizing WLB. Then we present a systematic analysis of the literature on WLB. Finally, we propose research areas and recommendations for further research on remote working as well as literature-based approaches to the maintenance of WLB by employees performing their work remotely. 


\section{WORK-LIFE BALANCE CONCEPTUALIZATION}

At the beginning of the discussion it is important to define the understanding of the term work life balance. There are various approaches to this term in the literature. WLB is considered to describe the relationship between an individual's professional responsibilities and his/ her private life, with satisfactory WLB referring to the preservation of time devoted to private life. (Kelliher et al. 2018). Furthermore, WLB can be defined as a positive perception of the integration of the diverse spheres of an individual's life, concerning both family and work, and minimizing the conflict between the different roles (Jang, Zippay, 2011). Brough et al. (2014) describes work-life balance as the individual's perception of the compatibility of different activities of the individual and the support of self-development and achievement of one's life priorities. Clark's (2000) definition also emphasizes that WLB means a situation where the conflict between an individual's commitment to family and professional responsibilities is minimized. Thus, minimizing conflict between work roles and nonwork roles is considered a desired state of individual satisfaction, called WLB (Sirgy, Lee, 2018). There are two approaches characterizing the research perspective of WLB. The first one refers to the improvement of the condition of family life and the second to the minimization of the above-mentioned conflict of roles (Sirgy, Lee, 2018). In this chapter, the conceptual analysis focuses on minimizing the role conflict that results from remote working. Therefore, for the purpose of the analysis, a perspective has been adopted, assuming the need to pursue conflict minimization as well as ensuring satisfaction and proper resource management (Fisher, et al., 2009).

The consequences of WLB can be categorized into work-related and nonwork-related outcomes (Sirgy, Lee, 2018). Past research shows that the work-related outcomes of WLB include: job performance increase (Blazovich et al., 2014; Whiston, Cinamon 2015). Moreover, WLB's relationship with job satisfaction is also indicated (Haar, Brougham 2020, De Simone et al., 2014; Hasan, Teng, 2017; Gragnano et al., 2020). Additionally, organizational engagement is linked to WLB satisfaction (Jaharuddin, Zainol, 2019; Talukder 2019, Haar, Brougham, 2020). In addition, the promotion of positive WLB among employees benefits from reduced absenteeism and turnover intentions (Wayne et al 2004; Abdien, 2019). Therefore, WLB results in a number of important organizational benefits.

Another category of important consequences of a satisfactory WLB is the nonworkrelated outcomes. The researchers indicate that the main WLB outcomes include: increased life satisfaction (Anaton, 2013), decreased family conflict (Westman, Etzion, 2005) and improved family satisfaction (Whiston, Cinamon, 2015). Given both types of satisfactory WLB outcomes, this is an important element of effective employee management.

\section{WORK-LIFE BALANCED AND REMOTE WORK SETTINGS}

There is a lack of consistency in the literature with regard to the analysis of the impact of working from home on WLB (Palumbo, 2020). The main advantages of remote working are indicated as the possibility of better management of responsibilities and easier avoidance of role conflict through increased plasticity of the home environment (Beauregard, Henry, 2009). Whereas, an analysis of the negative consequences of working from home on WLB, indicates empirical data suggesting that remote working reduces satisfaction with WLB (Felstead, Henseke, 2017). Remote working can contribute to WLB disturbance by prolonging actual working hours (Tipping et al., 2012) and overlapping domestic and professional duties (Hyman, Baldry, 2011). It may also lead to increased conflict between work and nonwork roles (Fonner, Stache, 2012), and, as a consequence, negatively impacted on WLB (Palumbo, 2020). Since, in the light of research, remote working has a negative impact on WLB (Felstead, Henseke, 2017), it is important to determine what factors shape WLB. Another negative factor associated with the use of remote working is the difficulty in adapting employees to the culture of the organization 
and their socialization and control practices (Popovici, Popovici 2020). This requires superiors to develop innovative solutions which, on the one hand, enable supervision and integration of employees and, on the other, will not deprive them of their autonomy.

The literature points to several factors that enable the satisfaction WLB of employees. The first one concerns organizational factors. Haar, Sune and Russo (2019) indicate that the supervisor support, understood as the perceived care and appreciation of the supervisor in the organization, will be an important factor driving WLB. Another factor that has a positive impact on WLB is work autonomy, which refers to the freedom of employees to self-manage their work without excessive control and supervision (Haar, Sune, Russo, 2019). So the independence of the job and the sense of support of the leader are important antecedents of WLB.

The second group of WLB antecedents concerns individual factors. Based on the analysis of the literature, it is concluded that factors relating in particular to the increased perception of work importance (May et al., 2004) as well as involvement in family life (Bulger, Fisher, 2012) are important predictors of WLB among employees. In addition, people with higher levels of selfefficiency also tend to be more satisfied with WLB (Mauno et al. 2007). Numerous studies also show that, with regard to personality traits, a low level of neuroticism is the most important factor determining satisfaction with WLB, by reducing the intensity of role conflict (Stavroula, Sulakshana 2016; Bulger, Fisher, 2012). In summary, the individual factors influencing WLB include family or professional involvement, as well as personality traits and self-confidence.

In view of the widespread use of remote working, it is necessary to enable employees who work from home due to the COVID-19 pandemic to maintain a satisfactory WLB. Therefore, the role of organizational factors determining WLB is increasing. It is up to the employer to provide instruments to improve the maintenance of WLB. WLB's strengthening measures make it possible to maintain employees' sense of well-being in situations of social isolation and remote working.

In a broader sense, there is a lack of data on specific tools to maintain the satisfaction of WLB for workers who work from home during a pandemic. It is therefore important to analyze the literature in order to diagnose conceptual clusters and to identify which areas need to be developed in order to provide valuable guidance on remote working. The following figure (fig. 1) shows the WLB conceptual model based on literature analysis. 


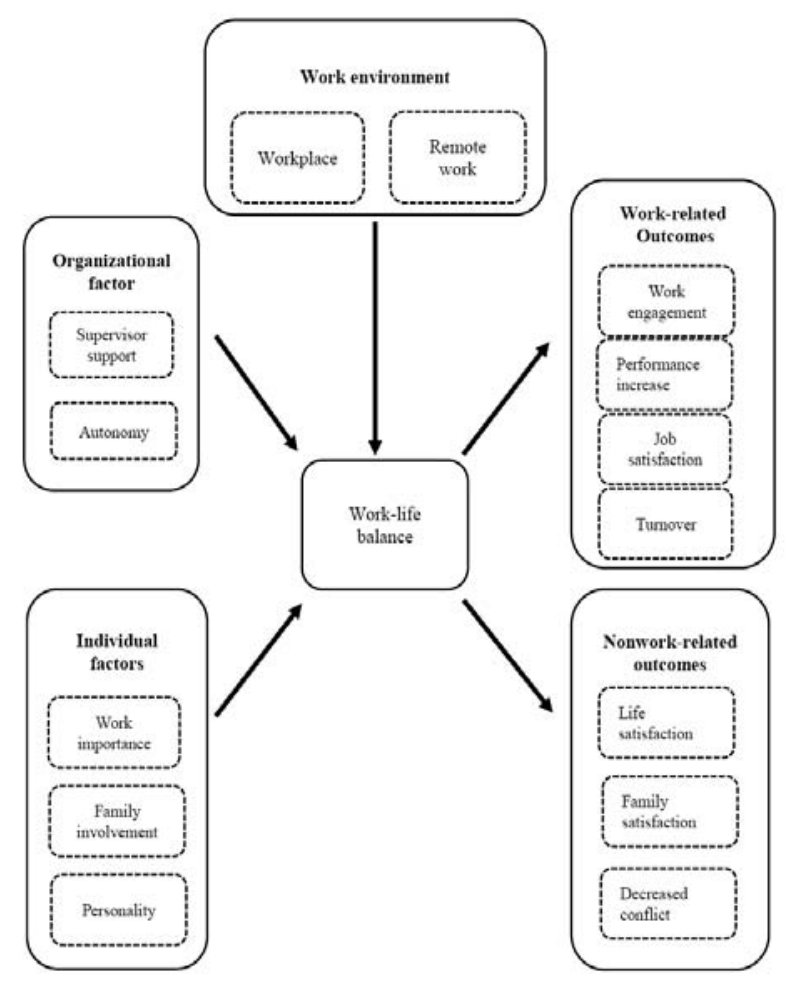

Figure 1. The conceptual model of WLB (Source: own elaboration)

\section{LITERATURE REVIEW ABOUT EMPLOYEE WORK-LIFE BALANCE}

The chapter uses bibliometric analysis using tools available in VOSviewer and the SCOPUS database. Described in this chapter the bibliometric review is based on the Scopus database with a selected sample containing all articles containing the key words "Work-life balance". According to Freire (2013), bibliometry is a technique to evaluate and measure the results of bibliographic research on a specific research question. Bibliometric analysis is also used to track change/progress and identify areas for future research (Opejin et al. 2020). The search for peerreviewed publications was conducted on 27 December 2020 in Elsevier Science Scopus. The SCOPUS database offers a comprehensive and high quality catalogue for this analysis and includes information on social and international sciences. According to Elsevier, Scopus is the 
largest database of summaries and quotations from peer-reviewed scientific literature. The category of "Business, Management, and Accounting" was used in order to contain only research results that are about work-life balance. As a result, 1034 publications from 2010 to the present year 2020 was exported and used in further analysis. The following techniques were used for the bibliometric analysis: the method of co-occurrence of words and clustering (cluster analysis) as well as the mind mapping method. The VOSviewer, XMind software was used, as well as the data analysis tools available in the database SCOPUS. The process of preliminary analysis resulted in $\mathrm{k}=1034$ sources for inclusion in our literature review.

\section{RESULTS}

In this section, we present the results of the review of the studies that were identified through our search for "work-life balance". Interest in research in the area of WLB is growing from year to year. Fig. 2 shows the number of publications per year that were published in the period 2010-2020. Already in 2010, there were 50 articles on the subject, while in 2016 it was already 106 publications, and in 2020. The great interest in work-life balance results from the increasing attention paid to the needs of the employee in the workplace, but also when working from home.

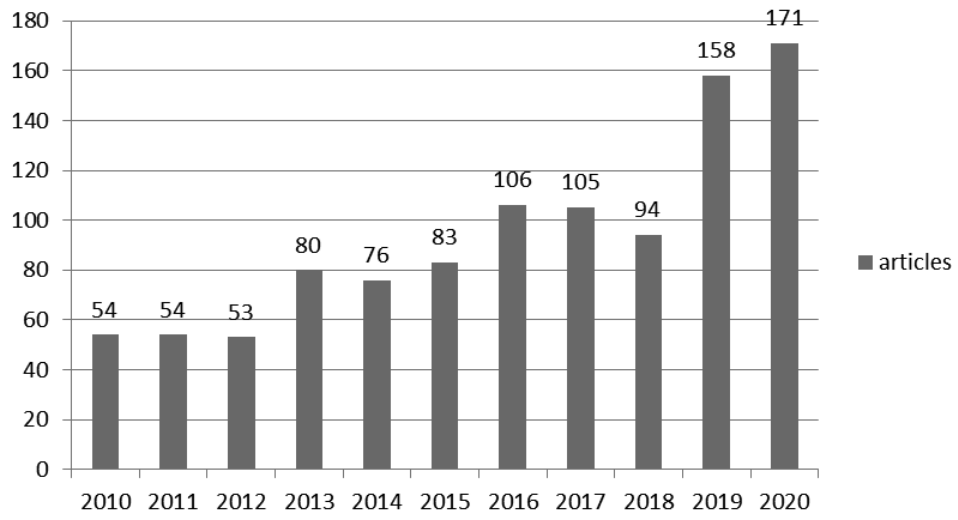

Figure 2. Number of publications in the period 2010-2020 concerning work-life balance.

Source: own work based on the Scopus database.

The interest in the studied area was diversified territorially. As shown in Figure 3, most attention was paid to this topic by researchers from the United States, United Kingdom, India and Australia. In the United States 212 articles were published. In the group of countries where about 50 articles have been published are: Canada, Germany, Spain. Figure 3 shows the number of publications from countries where authors published more than 15 articles in 2010-2020. The topic of work-life balance is a subject taken up by researchers from 51 countries. 


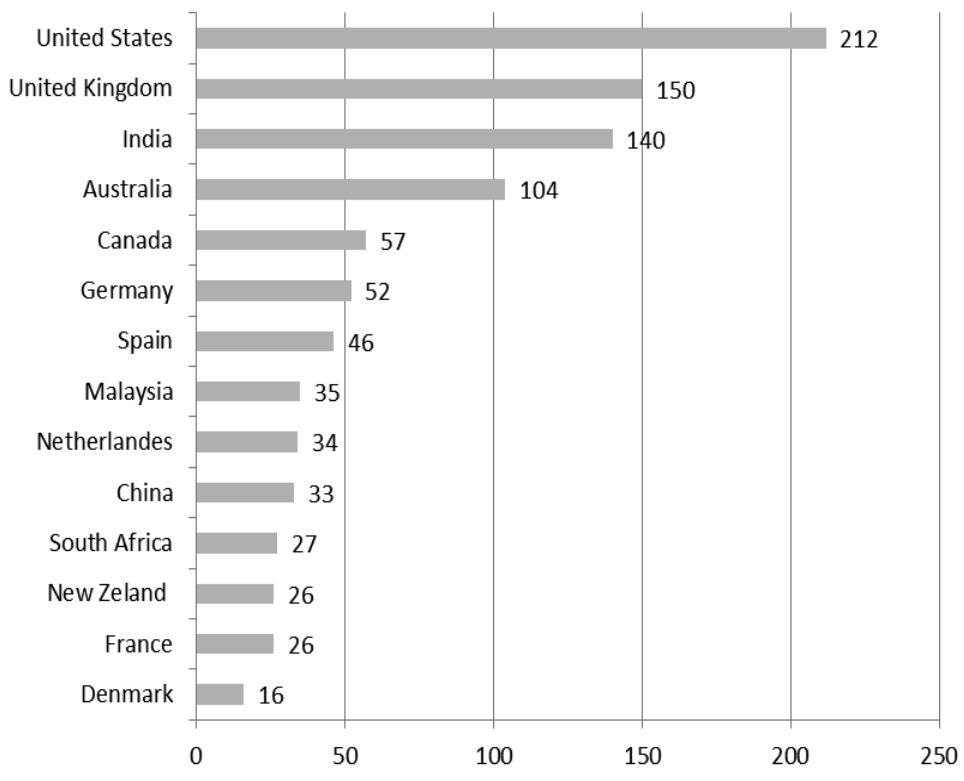

Figure 3. Number of publications on WLB by country Source: own work based on the Scopus database

The top 8 journals with the largest number of publications are as follows: International Journal of Human Resource Management (42), Personnel Review (31), Work Employment and Society (27), Human Resource Management (23), Gender work and Organization (22), Gender in Management (22) and Employee Relations (21) (tab.1). All 1034 papers analysed are scientific articles.

Table 1. Top 34 journals that published research articles related to work-life balance (2010-2020) 


\begin{tabular}{|c|c|}
\hline & of articles \\
\hline International Journal of Human Resource Management & 42 \\
\hline Personnel Review & 31 \\
\hline Human Resource Management International Digest & 28 \\
\hline Work Employment and Society & 27 \\
\hline Human Resource Management & 23 \\
\hline Gender Work and Organization & 22 \\
\hline Gender in Management & 22 \\
\hline Employee Relations & 21 \\
\hline New Technology, Work and Employment & 15 \\
\hline International Journal of Recent Technology and Engineering & 15 \\
\hline International Journal of Manpower & 14 \\
\hline Equality, Diversity and Inclusion & 14 \\
\hline Journal of Managerial Psychology & 10 \\
\hline Human Relations & 8 \\
\hline International Journal of Entrepreneurial Behaviour and Research & 7 \\
\hline European Management Journal & 7 \\
\hline International Journal of Organizational Analysis & 7 \\
\hline Journal of Asian Finance, Economics and Business & 7 \\
\hline International Journal of Workplace Health Management & 6 \\
\hline International Journal of Entrepreneurship & 6 \\
\hline International Journal of The Legal Profession & 6 \\
\hline Organization Science & 6 \\
\hline Advances in Developing Human Resources & 5 \\
\hline Construction Management and Economics & 5 \\
\hline Employee Responsibilities and Rights Journal & 5 \\
\hline Employee Responsibilities and Rights Journal & 5 \\
\hline European Journal of Training and Development & 5 \\
\hline European Journal of Work and Organizational Psychology & 5 \\
\hline Human Resource Development Quarterly & 5 \\
\hline International Journal of Public Administration & 5 \\
\hline Journal of Business Research & 5 \\
\hline Journal of Human Values & 5 \\
\hline Journal of Management and Organization & 5 \\
\hline Journal of Psychology: Interdisciplinary and Applied & 5 \\
\hline
\end{tabular}

\section{TERM CO-OCCURRENCE NETWORK MAP}

The next step in the analysis of literature was the map of the co-occurence network. The initial process of text data analysis in VOSviewer, including the title, keywords and abstract text, generated 21447 cumulative terms, then all words that have less than 10 speeches were excluded. Only 795 conditions met this threshold. Using the VOSviewer's hit ratings, we have established calculations for the level to which the deadline is specific and informative or general and non-informative (Van Eck, Waltman 2013). Only the terms within the highest $60 \%$ of the relevance scores were selected, reducing the number of terms to 477 . The terms were then 
checked by hand to remove words that discussed the research process (e.g. date, article, Scopus, author, keywords) or concerned countries such as Germany, India, UK. Excluding such general terms left us 224 phrases (terms, expressions) on the web.

Figure 4 shows the generated terms and their network of co-occurrences.

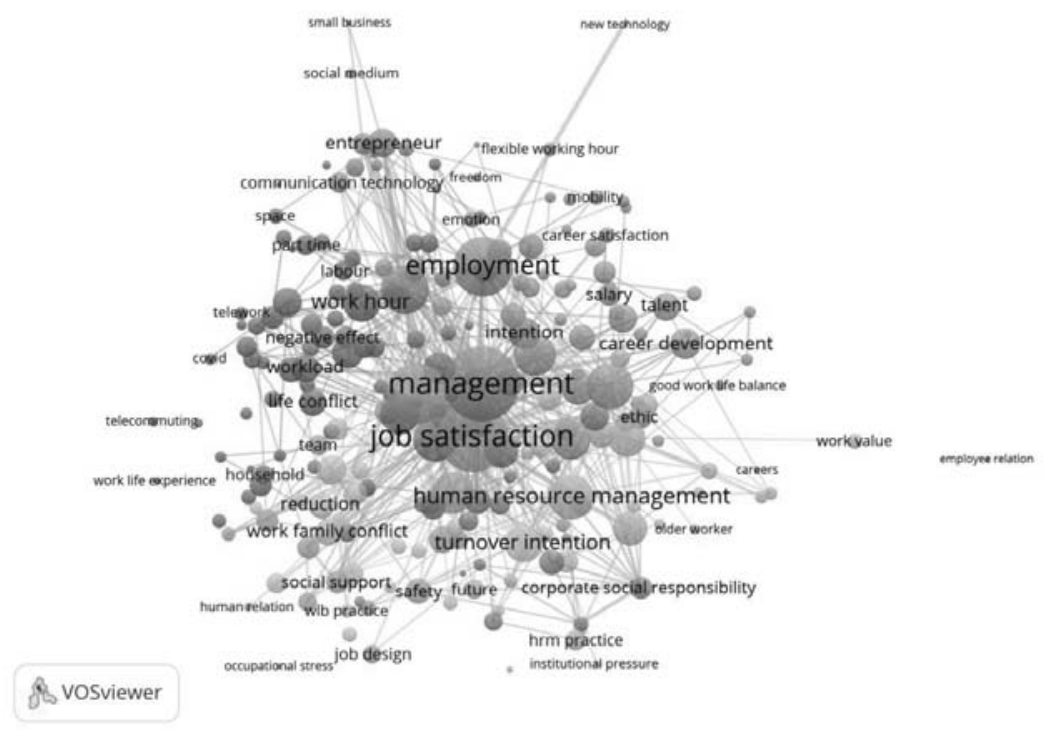

Figure 4. Network of terms from publication abstracts, title and key words Source: Authors'Vosviewer analysis.

From Figure 4 it can be concluded that WLB is a research area linked to very many aspects of the organisation's functioning, human resources management and the individual needs of employees.

The last element of the bibliometric analysis is the analysis of co-occurrence of words, which was used for grouping, that is, the analysis of clusters reflecting research sub-areas. In the visualization of a bibliometric network, VOSviewer uses colors to indicate the cluster to which a node has been assigned.

Cluster analysis of work-life balance literature showed the existence of seven main clusters (fig 5). The first cluster (red), can be described as work condition. This cluster (55 items) includes studies on the following aspects of environment and working conditions: working hour, flexible work, part time, self-employment, telework, teleworking, telecommuting, work condition, job quality, leisure time. 


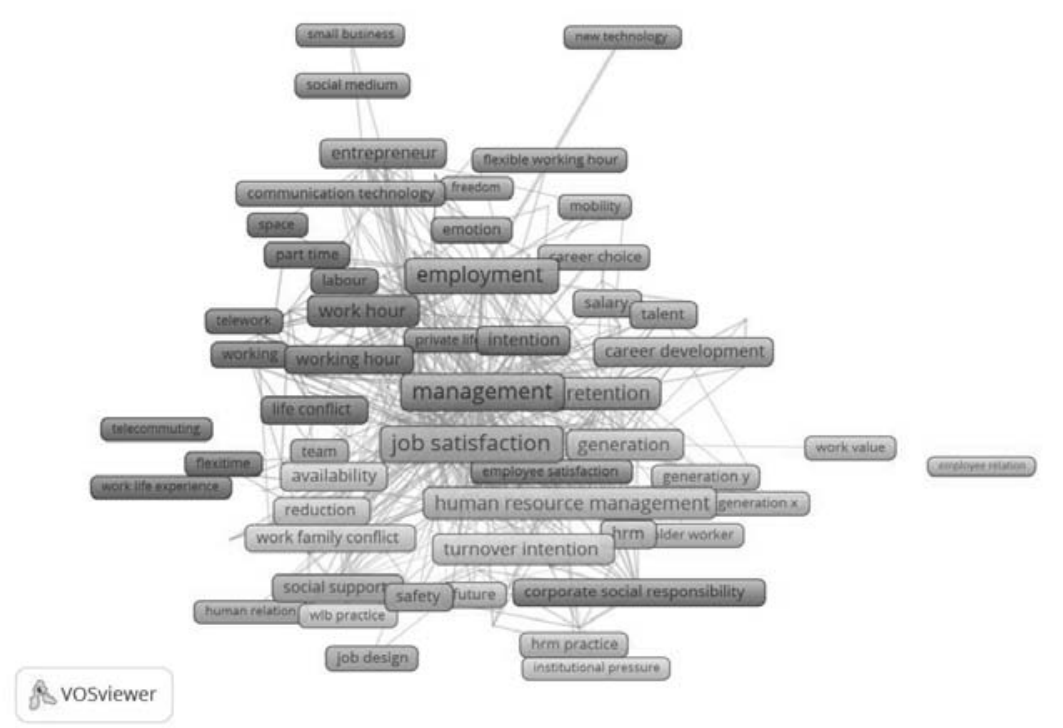

Figure 5. The clusters of work-life balance publications Source: Authors'Vosviewer analysis

The second cluster (green) refers to employee deployment. The cluster consists 44 items. The research in this area concerns WLB from the perspective of the employee and the employer. There have been some phrases here as: career development, career choice, mobility, job characteristic, job security, human capital, health care, talent management, retention, recruitment, training, employer branding.

The third cluster (dark blue) focuses on work engagement with 34 items such as employee satisfaction, career success, employee engagement, employee health, private life, wellbeing, organizational commitment, job performance, co-worker, leadership style, supervisor support. The fourth cluster (yellow) can be classified as perception of organization. It includes 30 items, such as: WLB practices, human resources practices, availability, burnout, employee perception, job autonomy, reduction, turnover intention, and WLB policy.

The fifth cluster (violet) is considered as technology management. It contains 21 items such as: communication technology, new technology, globalisation, employment, entrepreneur, work satisfaction, emotion,

Sixth cluster - human resource management (light blue) 20 units: generation $\mathrm{Y}$, generation $\mathrm{X}$, employee relation, older worker, millennium, HRM practice, stress management.

The seventh (orange) encompasses research aimed at job satisfaction, which includes 20 items, e.g: job control, organizational culture, team, job demand, human relations, investment. 
The results of the clustering of literature confirm that the topic of WLB is very diverse and covers many aspects. Most attention was paid to working condition. The areas of employment conditions that have gradually emerged in the practice of companies, such as flexible forms of employment (Smith et. al., 2019; Perrigino et al., 2018, Jackson, Fransman, 2018), have been addressed primarily for the well-being of employees and WLB (Kelly et al., 2020; Fontinha et al. 2019; Soni, Bakhru, 2019).

The subject of employee development is of great interest among scholars studying WLB. The research covers the employer's activities concerning WLB that will help to retain the employee in the organization through career development opportunities and trainings (Gupte 2020; Sheehan et al. 2019; Sîrbu, Alexandrescu 2014; Shibiti 2019). In addition, factors that determine the retention of an employee are analyzed, such as career development opportunities (AlAsfour et al., 2019), salary (Hammami et al., 2020; Suryaprakash, Hema Mary 2019).

Another key area of research is work engagement (Wood, Oh et al. 2020; Harini et al. 2020; Chan et al. 2017). The main focus of the investigation was on the impact of WLB on employee engagement resulting in improved work-related outcomes (Dilmaghani, 2020; Hutagalung et al. 2020) organizational commitment (Shabir, Gani 2020; Oyewobi et al. 2020) and the supervisor support (Kaur, Randhawa, 2020; Rahim et al., 2020)

The research covering perception of organization mainly concerned the organizational factors influencing WLB. Attention is drawn to WLB and HR practices in companies (Rashmi, Singh 2020; Martínez-León et al. 2019; Stavrou, Ierodiakonou 2016). An organization that seeks to meet the needs of employees, provides job autonomy (Mas-Machuca et al. 2016; Wood, Daniels et al. 2020), reduces turnover intention (Zahari et. al. 2020; Kaur, Randhawa 2020; Kashyap, Rangnekar 2014) and prevents burn-out (Geraldes et al. 2019; Cain et al. 2018).

At a time when information and communication technologies are developing, their use in the workplace is increasing (Wang et al. 2019; Hari 2017; Bardoel, Drago 2016). Technology management is another important aspect of WLB and job satisfaction (Peter, Kavitha 2020; Lee, 2019, Rao el al. 2019). Providing access to technological solutions increases work efficiency and enables, among others, work in virtual teams (Ruppel et al. 2013). Technology supports the process of communication, knowledge sharing and enables remote work (Naveena, Geevarghese 2019; Chen, Casterella 2019).

Another area of research is the management of different groups of workers. The research concerns the perception of WLB by employees of generation X, generation $Y$ or employees with extensive experience (Hassan et al. 2020). The attention paid to HR practices targeting different groups results in a better recognition of employees' needs, influencing the reduction of professional stress and improving mutual relations (Capnary et al. 2018).

The last very important area of research is the role of WLB in achieving job satisfaction (ALOmari et al. 2020; Adriano, Callaghan 2020; Pasko et al., 2020). Intra-organizational processes that are examined in this respect include e.g. work control, teamwork, and organizational culture (Peters et al. 2020; Panda, Kumar, Sahoo 2017; Espasandín-Bustelo et al. 2020; Kwon et al., 2019).

\section{WLB AND REMOTE WORK}

The research to date has addressed the problems of teleworking and telecommuting as forms of employment chosen by employees. However, very little attention has been paid to remote working as a necessity caused by a pandemic, which was a new way of working for both the employee and the employer. WLB in remote working conditions was included in 9 articles, which are listed in Table 2. 
The studies to date covering WLB and remote work are primarily quantitative studies. They include statistical analysis of data from large national surveys (Germany, UK, USA) or European Working Conditions Survey. The surveys, despite being published in 2020, include an analysis of statistical data from 2015-2016, thus not taking into account the remote working conditions caused by the pandemic. Remote working is carried out by choice and with the employee's consent.

Table 2. Overview of studies on WLB in the context of remote working

\begin{tabular}{|c|c|c|}
\hline $\begin{array}{c}\text { Author } \\
\text { Year } \\
\text { of publication }\end{array}$ & $\begin{array}{c}\text { Country of origin } \\
\text { Methodology } \\
\text { Population(s) studied }\end{array}$ & Results \\
\hline $\begin{array}{l}\text { Bellmann, L., } \\
\text { Hübler, O } \\
2020\end{array}$ & $\begin{array}{l}\text { Germany } \\
\text { Quantitative research } \\
\text { Linked Personnel Panel } \\
\text { 2012-2016 } \\
2012 / 2013(N=7,508), \\
2014 / 2015(N=7,282), \\
2016 / 2017(N=6,779)\end{array}$ & $\begin{array}{l}\text { No clear effects of remote work on job } \\
\text { satisfaction are revealed, but the impact on } \\
\text { work-life balance is generally negative }\end{array}$ \\
\hline $\begin{array}{l}\text { Palumbo, R. } \\
2020\end{array}$ & $\begin{array}{l}\text { European countries } \\
\text { Quantitative research } \\
\text { Sixth European Working } \\
\text { Conditions Survey (EWCS) } \\
\text { N=9877, } 2015 \text { year }\end{array}$ & $\begin{array}{l}\text { Home-based telecommuting negatively } \\
\text { affected the work-life balance of public } \\
\text { servants. Employees who remotely worked } \\
\text { from home suffered from increased work-to- } \\
\text { life and life-to-work conflicts. } \\
\text { Telecommuting from home triggered greater } \\
\text { work-related fatigue, which worsened the } \\
\text { perceived work-life balance. Work } \\
\text { engagement positively mediated the } \\
\text { negative effects of working from home on } \\
\text { work-life balance }\end{array}$ \\
\hline $\begin{array}{l}\text { Palumbo, R., } \\
\text { Manna, R., } \\
\text { Cavallone, M. } \\
2020\end{array}$ & $\begin{array}{l}\text { European countries } \\
\text { Quantitative research } \\
\text { 2,046 people employed } \\
\text { in the education sector; } \\
2015 \text { year }\end{array}$ & $\begin{array}{l}\text { The study suggests that home-based } \\
\text { telecommuting may trigger work-to-life and } \\
\text { life-to-work conflicts, } \\
\text { due to the blurring of boundaries between } \\
\text { work and everyday life. Soft tools, such as } \\
\text { organizational meaningfulness } \\
\text { (OM) and work-related well-being (WB), } \\
\text { mediate the relationship between working } \\
\text { from home (HW) and work-life } \\
\text { conflicts (WLC), lessening the negative } \\
\text { implications of working from home on } \\
\text { work-life balance }\end{array}$ \\
\hline $\begin{array}{l}\text { Thulin, E., } \\
\text { Vilhelmson, B., } \\
\text { Johansson, M. }\end{array}$ & $\begin{array}{l}\text { Sweden } \\
\text { Quantitative research } \\
\text { Logistic regression }\end{array}$ & $\begin{array}{l}\text { Results indicate that subjective time } \\
\text { pressure is not associated with job type in } \\
\text { terms of distinguishing between bounded } \\
\text { case work and more independent analytical }\end{array}$ \\
\hline
\end{tabular}




\begin{tabular}{|c|c|c|}
\hline $\begin{array}{c}\text { Author } \\
\text { Year } \\
\text { of publication }\end{array}$ & $\begin{array}{c}\text { Country of origin } \\
\text { Methodology } \\
\text { Population(s) studied }\end{array}$ & Results \\
\hline 2020 & $\begin{array}{l}456 \text { home-based teleworkers } \\
\text { employed by six } \\
\text { governmental agencies } \\
\text { in Sweden }\end{array}$ & $\begin{array}{l}\text { work. Time pressure is intensified by family- } \\
\text { related factors, telework performed outside } \\
\text { of working hours, and part-time } \\
\text { work, and is moderated by the private use of } \\
\text { smartphones. We find no significant } \\
\text { associations } \\
\text { between subjective time use control, job } \\
\text { qualifications, and teleworking practice }\end{array}$ \\
\hline $\begin{array}{l}\text { Grant, C.A., } \\
\text { Wallace, L.M., } \\
\text { Spurgeon, P.C., } \\
\text { Tramontano, C., } \\
\text { Charalampous M. } \\
2019\end{array}$ & $\begin{array}{l}\text { United Kingdom } \\
\text { Quantitative research } \\
\text { Exploratory factor analysis } \\
260 \text { e-workers, from } 11 \\
\text { organisations, across three } \\
\text { sectors }\end{array}$ & $\begin{array}{l}\text { Exploratory factor analysis supported a 17- } \\
\text { item scale assessing four factors: work-life } \\
\text { interference, } \\
\text { productivity, organisational trust and } \\
\text { flexibility. Individual well-being was } \\
\text { measured and a pattern of significant } \\
\text { correlations against four factors as indicators } \\
\text { of general health were found, including } \\
\text { mental health and vitality }\end{array}$ \\
\hline $\begin{array}{l}\text { McDowall, A., } \\
\text { Kinman, G. } \\
2017\end{array}$ & $\begin{array}{l}\text { United Kingdom } \\
\text { Quantitative research } \\
\text { Descriptive analysis } \\
374 \text { employees }\end{array}$ & $\begin{array}{l}\text { Over half of the organisations sampled do } \\
\text { not have clear policies, guidance or training } \\
\text { in place regarding work-life balance and } \\
\text { supporting employees with regards to } \\
\text { technology enabled working and } \\
\text { communications. The authors identify as key } \\
\text { challenges the sheer volume of e-mail traffic, } \\
\text { lack of training and infrastructure to support } \\
\text { ICT-enabled working and an absence of } \\
\text { appropriate support. }\end{array}$ \\
\hline $\begin{array}{l}\text { Felstead, A., } \\
\text { Henseke, G. } \\
2017\end{array}$ & $\begin{array}{l}\text { United Kingdom } \\
\text { Quantitative research } \\
\text { Descriptive and statistical } \\
\text { analysis } \\
\text { Labour Force Surveys 1992- } \\
2015 \\
\text { Skills and } \\
\text { Employment Survey }\end{array}$ & $\begin{array}{l}\text { the detachment of work from place is a } \\
\text { growing trend. This article shows that while } \\
\text { remote working is associated with higher } \\
\text { organisational commitment, job satisfaction } \\
\text { and job-related well-being, these benefits } \\
\text { come at the cost of work intensification and } \\
\text { a greater inability to switch off }\end{array}$ \\
\hline $\begin{array}{l}\text { Eddleston, K.A., } \\
\text { Mulki, J. } \\
2017\end{array}$ & $\begin{array}{l}\text { USA } \\
\text { Quantitative research } \\
\text { Descriptive statistics and } \\
\text { correlations; multi-method } \\
\text { approach }\end{array}$ & $\begin{array}{l}\text { This study revealed that working from home } \\
\text { creates unique challenges for remote } \\
\text { workers because the work role becomes } \\
\text { embedded in the family domain such that } \\
\text { their home comes to be associated with the } \\
\text { work role, work physically and } \\
\text { psychologically intrudes upon their family, }\end{array}$ \\
\hline
\end{tabular}




\begin{tabular}{|c|c|c|}
\hline $\begin{array}{c}\text { Author } \\
\text { Year } \\
\text { of publication }\end{array}$ & $\begin{array}{l}\text { Country of origin } \\
\text { Methodology } \\
\text { Population(s) studied }\end{array}$ & Results \\
\hline & 315 responses & $\begin{array}{l}\text { and habits and norms form that induce } \\
\text { remote workers to be preoccupied with } \\
\text { work when home. Our findings therefore } \\
\text { revealed that working solely from home } \\
\text { encourages remote workers to overwork and } \\
\text { to allow their work to infringe on their } \\
\text { family role. }\end{array}$ \\
\hline $\begin{array}{l}\text { Grant, C.A., } \\
\text { Wallace, L.M., } \\
\text { Spurgeon, P.C. } \\
2013\end{array}$ & $\begin{array}{l}\text { United Kingdom } \\
\text { Quantitative research } \\
\text { Longitudinal models } \\
11 \text { in-depth interviews with } \\
\text { e-workers, across five } \\
\text { organisations and three } \\
\text { sectors }\end{array}$ & $\begin{array}{l}\text { Adverse impacts were found on well-being, } \\
\text { due to over-working and a lack of time for } \\
\text { recuperation. Trust and management style } \\
\text { were found to be key influences on e-worker } \\
\text { effectiveness }\end{array}$ \\
\hline
\end{tabular}

Studies focusing on the impact of home office work on WLB also highlight the negative consequences of such work arrangements. These studies suggest a negative impact of homework on workers' WLB (Bellmann, Hbiler, 2020; Palumbo, 2020). In addition, they suggest that working from home makes it more difficult for workers to switch off and rest, which can, in the long term, disrupt WLB. (Felstead, Henseke, 2017). Moreover, studies indicate that there is a possibility of intensifying the conflict of roles due to the interplay of boundaries between professional and family responsibilities (Eddleston, Mulki, 2017; Thulin, Vilhelmson, Johansson, 2020). The results of these studies indicate the need to develop clear personnel policies to support employees working remotely (McDowall, Kinman, 2017). In conclusion, studies on the relationship between remote working and WLB point to the challenges faced by organizations in providing an appropriate system of support for employees. Intensification of work, extension of the actual time spent in front of the computer, as well as increased role conflict and the burden of technological overload are real difficulties resulting from the use of work from home. Therefore, it is important to identify possible ways in which these challenges can be addressed through appropriate management practices in organizations. 


\section{CONCLUSION}

The structure of WLB research was mapped and then presented in seven conceptual clusters: cluster no 1 identifies working condition, cluster no 2 combines employees development, cluster no 3 links work engagement, cluster no 4 concerns perception of organizations, cluster no 5 refers to technology management, cluster no 6 covers human resource management and cluster no 7 ties job satisfaction. The findings of this chapter contribute to the further development of the research in the WLB. The identified clusters have highlighted key areas of WLB conceptualization.

When analyzing the outlined research areas in the context of the COVID-19 pandemic and the need to work remotely, it is worth considering which management practices will enable WLB to be improved when working from home. Identifying the most important aspects of supporting employees in achieving WLB and maintaining mental well-being while working remotely is a valuable information resource for both managers and those who work from home.

Technology is an essential factor in supporting WLB in remote working conditions. As empirical research on remote working has shown, technology can enable a better connection with colleagues and also better monitoring of work by superiors (McDowall, Kinman, 2017; Popovici, Popovici 2020). Ensuring the socialization of employees through appropriate use of technology is an important factor in increasing WLB among home workers (Dolot, 2020). This is all the more valuable because research suggests that workers feel depersonalized and isolated during the COVID-19 pandemic (Almonacid-Nieto, Calderón Espinal, Vicente-Ramos, 2020). An important area of research on WLB is the career development of employees. One of the main factors influencing the positive perception of an organization and willingness to stay at work is the opportunity for employees' development and training. This is in line with research Wolor, Solikhah, Fidhyallah, and Lestari (2020), which suggests a significant impact of e-training on employee productivity during the COVID-19 pandemic. In the context of job satisfaction in remote working conditions, the results of the literature analysis correspond to the empirical research of workers working from home during the pandemic implying that remote working - especially at the beginning significantly increases job satisfaction (Bellmann, Hübler,2020; Hashim, Bakar, Noh, \& Mahyudin, 2020). However, that technology-intensive remote working can reduce job satisfaction (Suh, Lee, 2017). Further research is therefore needed into the relationship between WLB and job satisfaction in remote working conditions. Ensuring the engagement of employees during remote working hours is also another important challenge (Pattnaik, Jena 2020). Since one of the work-related outcomes of WLB is precisely engagement, further research should explore reinforcing mechanisms for WLB in order to build engaged remote workers. The above analysis of the literature has provided scientific contributions to the WLB concept in two ways. Firstly, it presented research areas and structured WLB's conceptualizations in the literature. Secondly, it identified key areas for further research related to a deeper understanding of WLB in remote working environments. Additionally, it outlined a set of prescriptive recommendations for further development and WLB investigations. In general, this chapter highlights the need to elaborate on WLB in the context of working from home. 


\section{REFERENCES}

Abdien, M. (2019). Impact of communication satisfaction and work-life balance on employee turnover intention. Journal of Tourism Theory and Research, 5(2), pp. 228-238 .

Adriano, J., \& Callaghan, C.W. (2020). Work-life balance, job satisfaction and retention: Turnover intentions of professionals in part-time study, South African Journal of Economic and Management Sciences, 23 (1), art. no. a3028, pp. 1-12.

Al-Asfour, A., Tlaiss, H.A., \& Shield, S.W. (2019). Work Experiences of Native Americans: A Qualitative Study, Journal of Career Development

Almonacid-Nieto, J.M., Calderón-Espinal, M.A., \& Vicente-Ramos, W. (2020). Teleworking effect on job burnout of higher education administrative personnel in the Junín region, Peru, International Journal of Data and Network Science, 4(4), pp. 373-380.

AL-Omari, G.I., Hanandeh, R., Al-Somaidaee, M.M., Al Jarrah, M.A., \& Alnajdawi, S. (2020). Work-life balance and its impact on employee satisfaction on five star hotels, Management Science Letters, 10 (4), pp. 871-880.

Anaton, L. (2013). A proposed conceptual framework of work-family/family-work facilitation (WFF/FWF) approach in inter-role conflict. Journal of Global Management, 6, pp. 89-100.

Bardoel, E.A., \& Drago, R. (2016). Does the quality of information technology support affect work-life balance? A study of Australian physicians, International Journal of Human Resource Management, 27 (21), pp. 2604-2620.

Beauregard, T.A., \& Henry, L.C. (2009). Making the link between work-life balance practices and organizational performance, Human Resource Management Review, 19(1), pp. 9-22.

Bellmann, L., \& Hübler, O. (2020). Job Satisfaction and Work-Life Balance: Differences between Homework and Work at the Workplace of the Company. IZA Discussion Paper No. 13504, Retrieved from: https://ssrn.com/abstract $=3660250$

Blazovich, J. L., Smith, K. T., \& Smith, L.M. (2014). Employee-friendly companies and work-life balance: is there an impact on financial performance and risk level? Journal of Organizational Culture, Communications and Conflict, 18, pp. 1-13.

Brough P., Timms C., O’Driscol M., Kalliath T., Siu OL., Sit. C.\& Lo D. (2014). Work-life balance: A longitudinal evaluation of a new measure across Australia and New Zealand workers, International Journal of Human Resource Management 25(19) pp.2724-2744,

Bulger, C. A., \& Fisher, G. G. (2012). Ethical imperatives of work/life balance. In N. P. Reilly, M. J. Sirgy, \& C. A. Gorman (Eds.), Work and quality of life (pp. 181-202). Dordrecht: Springer.

Cain, L., Busser, J., \& Kang, H.J. (2018).Executive chefs' calling: effect on engagement, work-life balance and life satisfaction, International Journal of Contemporary Hospitality Management, 30 (5), pp. 2287-2307.

Capnary, M.C., Rachmawati, R., \& Agung, I. (2018). The influence of flexibility of work to loyalty and employee satisfaction mediated by work life balance to employees with millennial generation background in Indonesia startup companies, Business: Theory and Practice, 19, pp. 217-227.

Chan, X.W., Kalliath, T., Brough, P., O’Driscoll, M., Siu, O.-L., \& Timms, C. (2017). Self-efficacy and work engagement: test of a chain model, International Journal of Manpower, 38 (6), pp. 819-834.

Chen, A., \& Casterella, G.I. (2019). After-Hours Work Connectivity: Technological Antecedents and Implications, IEEE Transactions on Professional Communication, 62 (1), art. no. 8509198, pp. 75-93. 
Chung, H., \& van der Lippe, T. (2020). Flexible Working, Work-Life Balance, and Gender Equality: Introduction. Social Indicators Research 151, 365-381

Clark, S.C. (2000). Work/Family Border Theory: A New Theory of Work/Family Balance, Human Relations 53 (6), pp.747-770

De Simone, S., Lampis, J., Lasio, D., Serri, F., Ciotto, G., \& Putzu, D. (2014). Influences of workfamily interface on job and life satisfaction. Applied Research in Quality of Life, 9, pp. 831861.

Dolot A. (2020). The influence of COVID-19 pandemic on the remote work - an employee perspective, E-Mentor 1, pp 35-43.

Dilmaghani, M. (2020). There is a time and a place for work: comparative evaluation of flexible work arrangements in Canada, International Journal of Manpower

Eddleston, K.A., \& Mulki, J. (2017). Toward Understanding Remote Workers' Management of Work-Family Boundaries: The Complexity of Workplace Embeddedness, Group and Organization Management, 42 (3), pp. 346-387.

Espasandín-Bustelo, F., Ganaza-Vargas, J., \& Diaz-Carrion, R. (2020). Employee happiness and corporate social responsibility: the role of organizational culture, Employee Relations.

Felstead A., \& Henseke G. (2017). Assessing the growth of remote working and its consequences for effort, well-being and work-life balance, New Technology, Work and Employment 32 (3). pp. 195-212.

Fisher, G. G., Bulger, C. A., \& Smith, C. S. (2009). Beyond work and family: a measure of work/nonwork interference and enhancement. Journal of Occupational Health Psychology, 14, 441-456.

Fonner, K.L. \& Stache, L.C. (2012). All in a day's work, at home: teleworkers' management of micro role transitions and the work-home boundary, New Technology, Work and Employment, 27(3), pp. 242-257.

Fontinha, R., Easton, S., \& Van Laar, D. (2019). Overtime and quality of working life in academics and nonacademics: The role of perceived work-life balance, International Journal of Stress Management, 26 (2), pp. 173-183.

Geraldes, D., Madeira, E., Carvalho, V.S., \& Chambel, M.J. (2019). Work-personal life conflict and burnout in contact centers: The moderating role of affective commitment, Personnel Review, 48 (2), pp. 400-416.

Gragnano, A., Simbula, S., \& Miglioretti, M. (2020). Work-Life Balance: Weighing the Importance of Work-Family and Work-Health Balance. International Journal of Environmental Research and Public Health, 17, 907.

Grant, C.A., Wallace, L.M., \& Spurgeon, P.C., Tramontano, C., Charalampous, M. (2019). Construction and initial validation of the E-Work Life Scale to measure remote eworking, Employee Relations, 41 (1), pp. 16-33

Grant, C.A., Wallace, L.M., \& Spurgeon, P.C. (2013). An exploration of the psychological factors affecting remote e-worker's job effectiveness, well-being and work-life balance, Employee Relations, 35 (5), pp. 527-546.

Gupte, T.S. (2020). A study on employee retention strategies adopted by ICICI bank, International Journal of Scientific and Technology Research, 9 (4), pp. 3373-3382.

Haar, J. \& Brougham D. (2020). Work antecedents and consequences of work-life balance: A two sample study within New Zealand, The International Journal of Human Resource Management. 
Haar, J.M., Sune, A., Russo, M., \& Ollier-Malaterre A. (2019). A Cross-National Study on the Antecedents of Work-Life Balance from the Fit and Balance Perspective. Social Indicator Research 142, pp. 261-282 (2019).

Hammami, A., Moldovan, R., \& Peltier, E. (2020). Salary perception and career prospects in audit firms, Managerial Auditing Journal, 35 (6), pp. 759-793.

Hari, A. (2017). Who Gets to 'Work Hard, Play Hard'? Gendering the Work-Life Balance Rhetoric in Canadian Tech Companies, Gender, Work and Organization, 24 (2), pp. 99-114.

Harini, S., Hamidah, Luddin, M.R., \& Ali, H. (2020). Analysis supply chain management factors of lecturer's turnover phenomenon, International Journal of Supply Chain Management, 9 (1), pp. 582-591.

Hasan, N., \& Teng, LS. (2017). Work-life balance and job satisfaction among working adults in Malaysia: The role of gender and race as moderators, Journal of Economics, Business and Management, 5(1), pp.18- 24.

Hashim, R., Bakar, A., Noh, I., \& Mahyudin, H. A. (2020). Employees' Job Satisfaction and Performance through working from Home during the Pandemic Lockdown. Environment-Behaviour Proceedings Journal, 5(15), pp. 461-467.

Hassan, M.D.M., Jambulingam, M., Alagas, E.N., Uzir, M.U.H., \& Halbusi, H.A. (2020). Necessities and Ways of Combating Dissatisfactions at Workplaces Against the JobHopping Generation Y Employees, Global Business Review.

Hutagalung, I., Soelton, M., \& Octaviani, A. (2020). The role of work life balance for organizational commitment, Management Science Letters, 10 (15), pp. 3693-3700.

Hyman, J., \& Baldry, C. (2011), The pressures of commitment: taking software home, in Kaiser, S., Ringlstetter, M.J., Eikhof, D.R. and Cunha, M.P.E. (Eds), Creating Balance? International Perspectives on the Work-Life Integration of Professionals, Springer, Berlin, pp. 253-268.

Jackson, L.T.B., \& Fransman, E.I. (2018). Flexi work, financial well-being, work-life balance and their effects on subjective experiences of productivity and job satisfaction of females in an institution of higher learning, South African Journal of Economic and Management Sciences, 21 (1), art. no. a1487.

Jang, S. J., \& Zippay, A. (2011). The juggling act: Managing work-life conflict and work-life balance. Families in Society, 92(1), 84-90.

Jaharuddin, N.S., \& Zainol, L.N. (2019). The Impact of Work-Life Balance on Job Engagement and Turnover Intention, The South East Asian Journal of Management, 13 (1), pp. 106-118

Kashyap, V., \& Rangnekar, S. (2014). Structural Equation Model for Measuring the Impact of Employee Retention Practices on Employee's Turnover Intentions: An Indian Perspective, South Asian Journal of Human Resources Management, 1 (2), pp. 221-247.

Kaur, R., \& Randhawa, G. (2020). Supportive supervisor to curtail turnover intentions: do employee engagement and work-life balance play any role? Evidence-based HRM, vol. ahead-of-print No. ahead-of-print

Kelliher C., Richardson J. \& Boiarintseva G. (2019). All of work? All of life? Reconceptualising work-life balance for the 21st century. Human Resource Management Journal, 29 (2), pp. 97112.

Kelly, C.M., Rofcanin, Y., Las Heras, M., Ogbonnaya, C., Marescaux, E., \& Bosch, M.J. (2020). Seeking an "i-deal" balance: Schedule-flexibility i-deals as mediating mechanisms between supervisor emotional support and employee work and home performance, Journal of Vocational Behavior, 118, art. no. 103369. 
Kinnunen, M.L. \& Suutari, V. (2015). Work-to-life conflict and enrichment among international business travelers: The role of international career orientation. Human Resource Management, 54(3), 517-531.

Kwon, M., Cho, Y.J., \& Song, H.J. (2019). How do managerial, task, and individual factors influence flexible work arrangement participation and abandonment?, Asia Pacific Journal of Human Resources.

Lee, H.-W. (2019). How Does Sustainability-Oriented Human Resource Management Work?: Examining Mediators on Organizational Performance, International Journal of Public Administration, 42 (11), pp. 974-984.

Martínez-León, I.M., Olmedo-Cifuentes, I., \& Sanchez-Vidal, M.E. (2019). Relationship between availability of WLB practices and financial results, Personnel Review, 48 (4), pp. 935-956.

Mas-Machuca, M., Berbegal-Mirabent, J., \& Alegre, I. (2016). Work-life balance and its relationship with organizational pride and job satisfaction, Journal of Managerial Psychology, 31 (2), pp. 586-602.

Mauno, S., Kinnunen, U., \& Ruokolainen, M. (2007). Job demands and resources as antecedents of work engagement: a longitudinal study. Journal of Organizational Behavior, 70, pp. 149171.

May, D. R., Gilson, R. L., \& Harter, L. M. (2004). The psychological conditions of meaningfulness, safety and availability and the engagement of the human spirit at work. Journal of Occupational and Organizational Psychology, 77, pp. 11-37.

McDowall, A., \& Kinman, G. (2017). The new nowhere land? A research and practice agenda for the "always on" culture, Journal of Organizational Effectiveness, 4 (3), pp. 256-266.

Muralidhar, B. Prasad, Dr. KDV \& Rao, M., (2020). Association among Remote Working Concerns and Challenges on Employee Work-Life Balance: An Empirical Study Using Multiple Regression Analysis with Reference to International Agricultural Research Institute, Hyderabad (July 14, 2020). International Journal of Advanced Research in Engineering and Technology, 11(6), pp. 281-297 Retrieved from: https://ssrn.com/abstract $=3650802$

Naveena, M., \& Geevarghese, G. (2019). Job satisfaction of academicians-a conceptual study in higher educational sector, International Journal of Recent Technology and Engineering, 8 (1C2), pp. 17-21.

Opejin A.K., Aggarwal R.M., White D.D., Jones J.L., Maciejewski R., Mascaro G., \& Sarjoughian H.S. A Bibliometric Analysis of Food-Energy-Water Nexus Literature, 2020 Sustainability 12,1112

Oyewobi, L.O., Oke, A.E., Adeneye, T.D., Jimoh, R.A., \& Windapo, A.O. (2020). Impact of worklife policies on organizational commitment of construction professionals: role of worklife balance, International Journal of Construction Management.

Ozimek, A. (2020). The Future of Remote Work. Preprint from SSRN. Retrieved from: https://europepmc.org/article/ppr/ppr242674.

Palumbo, R. (2020). Let me go to the office! An investigation into the side effects of working from home on work-life balance, International Journal of Public Sector Management, 33 (6/7), pp. 771-790.

Palumbo, R., Manna, R., \& Cavallone, M. (2020). Beware of side effects on quality! Investigating the implications of home working on work-life balance in educational services, TQM Journal. 
Panda, A., \& Kumar Sahoo, C. (2017). Impact of human resource interventions on work-life balance: a study on Indian IT sector, Industrial and Commercial Training, 49 (7-8), pp. 329336.

Pasko, R., Maellaro, R., \& Stodnick, M. (2020). A study of millennials' preferred work-related attributes and retention, Employee Relations.

Pattnaik, L., \& Jena, L.K. (2020). Mindfulness, remote engagement and employee morale: conceptual analysis to address the "new normal", International Journal of Organizational Analysis, Vol. ahead-of-print No. ahead-of-print.

Perrigino, M.B., Dunford, B.B., \& Wilson, K.S. (2018). Work-family backlash: The "dark side" of work-life balance (wlb) policies, Academy of Management Annals, 12 (2), pp. 600-630.

Peter, M., \& Kavitha, S.F. (2020). A study on the impact of work life balance on the well being of employees at Quantum Software Solutions Pvt Ltd, International Journal of Advanced Research in Engineering and Technology, 11 (3), pp. 120-127.

Peters, P., Blomme, R., de Jager, W., \& van der Heijden, B. (2020). The impact of work-related values and work control on the career satisfaction of female freelancers, Small Business Economics, 55 (2), pp. 493-506.

Popovici V., \& Popovici A.L. (2020). Remote Work Revolution:Current Opportunities and Challenges for Organizations, "Ovidius" University Annals, Economic Sciences Series. XX(1), pp 468-472.

Rahim, N.B., Osman, I., \& Arumugam, P.V. (2020). Linking work-life balance and employee well-being: Do supervisor support and family support moderate the relationship? International Journal of Business and Society, 21 (2), pp. 588-606.

Rao, A.L., Kulshrestha, N., \& Ramakrishnan, G. (2019). Adaptability and applicability of need hierarchy theory in assessing employee satisfaction with special reference to EPC company of UAE, International Journal of Business Excellence, 19 (1), pp. 1-15.

Rashmi, K., \& Singh, R. (2020). Building competitive advantage through engagement of employees: A conceptual model, International Journal of Interdisciplinary Organizational Studies, 15 (1), pp. 1-11.

Ruppel, C.P., Gong, B., \& Tworoger, L.C. (2013). Using Communication Choices as a BoundaryManagement Strategy: How Choices of Communication Media Affect the Work-Life Balance of Teleworkers in a Global Virtual Team, Journal of Business and Technical Communication, 27 (4), pp. 436-471.

Russo, M., Shteigman A. \& Carmeli A. (2016). Workplace and family support and work-life balance: Implications for individual psychological availability and energy at work, The Journal of Positive Psychology, 11:2, 173-188.

Shabir, S., \& Gani, A. (2020). Impact of work-life balance on organizational commitment of women health-care workers: Structural modeling approach, International Journal of Organizational Analysis, 28 (4), pp. 917-939.

Sheehan, C., Tham, T.L., Holland, P., \& Cooper, B. (2019). Psychological contract fulfilment, engagement and nurse professional turnover intention, International Journal of Manpower, 40 (1), pp. 2-16.

Shibiti, R. (2019). Satisfaction with retention factors in relation to job embeddedness of public school teachers, SA Journal of Human Resource Management, 17, art. no. a1161.

Sîrbu, J., \& Alexandrescu, R. (2014). Human resources policy - importance and applicability, Quality - Access to Success, 15 (SUPPL 3), pp. 23-31. 
Singh, N., Warrier, U., \& Bharti, T. (2019). Emotional intelligence strategies to achieve subjective career success: implications for learning and development in knowledge industry, Development and Learning in Organizations, 34 (3), pp. 23-26.

Sirgy, M., \& Lee, DJ. (2018). Work-Life Balance: an Integrative Review. Applied Research Quality Life 13, pp. 229-254.

Smith, E.F., Gilmer, D.O., \& Stockdale, M.S. (2019). The importance of culture and support for workplace flexibility: An ecological framework for understanding flexibility support structures, Business Horizons, 62 (5), pp. 557-566.

Songsangyos P., \& Iamamporn S. (2019). Remote Working with Work-life Balance International Journal of Applied Computer Technology and Information Systems, 9 (2).

Soni, P., \& Bakhru, K.M. (2019). Understanding triangulated collaboration of work-life balance, personality traits and eudaimonic well-being, Problems and Perspectives in Management, 17 (2), pp. 63-82.

Stavrou, E., \& Ierodiakonou, C. (2016). Entitlement to Work-Life Balance Support: Employee/Manager Perceptual Discrepancies and Their Effect on Outcomes, Human Resource Management, 55 (5), pp. 845-869.

Stavroula L., \& Sulakshana DA. (2016). Work, Life and Personality: The Relationship Between the Big Five Personality Traits and Work-life Conflict. South Asian Journal of Management, 23(4) pp. 31-53.

Suh, A., \& Lee, J. (2017). Understanding teleworkers' technostress and its influence on job satisfaction, Internet Research, 27(1), pp. 140-159.

Suryaprakash, V.M., \& Hema Mary, M. (2019). The influence of workplace comfort towards job satisfaction among private bank employees, International Journal of Recent Technology and Engineering, 8 (3), pp. 4019-4024.

Talukder AKM. (2019). Supervisor Support and Organizational Commitment: The Role of Work-Family Conflict, Job Satisfaction, and Work-Life Balance, Journal of Employment Counseling, 56(3), pp 98-116.

Tipping S., Chanfreau J., \& Perry J., Tait C.,The Fourth Work Life Balance Employees Suvey. Employees Relations Research Series 122. Department for Business, Innovation and Skills, London 2012.

Thulin, E., Vilhelmson, B., \& Johansson, M. (2019). New telework, time pressure, and time use control in everyday life, Sustainability, 11 (11), 3067

Wang, X., Gao, L., \& Lin, Z. (2019). Help or harm? The effects of ICTs usage on work-life balance, Journal of Managerial Psychology, 34 (8), pp. 533-545.

Wagner, D. T., Barnes, C. M., \& Scott, B. A. (2014). Driving it home: How workplace emotional labor harms employee home life. Personnel Psychology, 67(2), 487-516

Wayne, J. H., Musisca, N., \& Fleeson, W. (2004). Considering the role of personality in the workfamily experience: relationships of the big five to work-family conflict and facilitation. Journal of Vocational Behavior, 64, pp. 108-130

Westman, M., \& Etzion, D. (2005). The Crossover of Work-Family Conflict From One Spouse to the Other 1, Journal of Applied Social Psychology 35(9), pp. 1936-1957.

Whiston, S. C., \& Cinamon, R. G. (2015). The work-family interface: integrating research and career counselling practice. Career Development Quarterly, 63, pp. 44-56.

Wolor, C.W., Solikhah, S., Fidhyallah, N.F., \& Lestari, D.P. (2020). Effectiveness of E-Training, ELeadership, and Work Life Balance on Employee Performance during COVID-19, Journal of Asian Finance, Economics and Business, 7 (10), pp. 443-450. 
Wood, J., Oh, J., Park, J., \& Kim, W. (2020). The Relationship Between Work Engagement and Work-Life Balance in Organizations: A Review of the Empirical Research. Human Resource Development Review, 1534484320917560.

Wood, S., Daniels, K., \& Ogbonnaya, C. (2020). Use of work-nonwork supports and employee well-being: the mediating roles of job demands, job control, supportive management and work-nonwork conflict, International Journal of Human Resource Management, 31 (14), pp. 1793-1824.

Van Eck, N., \& Waltman, L. VOSviewer Manual; Univeristeit Leiden: Leiden, The Netherlands, 2013

Zahari, A.E., Supriyati, Y., \& Santoso, B. (2020). The influence of supply chain management and organization performance toward turnover intention at the head office of PT Bank Syariah Mandiri, International Journal of Supply Chain Management, 9 (4), pp. 1103-1116. 


\title{
Chapter 5
}

\section{A Leader's Abilities to Manage Work- related Emotions during a Crisis}

\author{
Donta S Harper
}

\begin{abstract}
The pandemic (COVID-19) caused by the novel coronavirus spread throughout the world such that it has become a part of our lives. The wrath of the pathogen has left almost nothing unaffected. On average, adults spend 7.9 hours working (Bureau of Labor Statistics, 2020). The societal crisis in the form of the pandemic has led to psychological and physiological stress and other adverse consequences, and given their positions, organizational leaders must be skilled at assisting their employees in the management of work-related emotions. This chapter brings forth evidence, based on the review of emotion regulation literature. Specifically, this chapter focuses on the conceptualization of work-related abilities by examining a model for extrinsic interpersonal emotional management. It introduces a single conceptual framework of testable and preliminary skills. The ERSA model theorizes that human agencies are explanatory for why individuals are effective at assisting others with the management of their emotions. These skills are emotion regulation of others, i.e., efficacy, emotional intelligence as an ability, and their utilization in an emotion regulatory process of managing others' emotions. These skills when used in combination with emotion modulation skills provide predictability regarding a leader's behavior. The skills-abilities in the ERSA model provides a framework for understanding a leader or individual regulating other person emotion proficiencies related to identified skills.
\end{abstract}

Keywords: interpersonal emotion regulation, emotion regulation, extrinsic regulator, the emotion regulation skills-abilities model 


\section{INTRODUCTION}

\section{A Leader's Abilities to Manage Work-related Emotions during a Crisis}

A successful leader must rely on the skills they have and those acquired in the performance of their work-related tasks and activities. Some skills are psychological competencies in the domain of interpersonal. A leader's interpersonal skills impact their effectiveness if utilized appropriately (Opengart, 2005). Mintzberg (1973) developed a managerial model of competencies and a competencies inventory. One of the competencies identified as essential for leadership is interpersonal skills. Interpersonal skills as a competency for leadership's effectiveness has become a critical competency today.

This chapter also focuses on the emerging science of interpersonal emotion regulation versus intrapersonal emotion regulation, which is an aspect of emotion regulation that has received much attention in the field of emotion regulation (Nozaki et al., 2020). In this regard, this chapter focuses on the ability, from a leadership perspective, of an interpersonal extrinsic regulator to regulate another person's emotions as a response-dependent process. Interpersonal regulation using an interpersonal extrinsic regulation process (is when a person uses another person to regulate their emotions and the regulator actively attempts to regulate their emotional trajectory or emotional state to change it). Today, there is emerging evidence regarding the learning vis-avis the interpersonal emotion regulation processes as a useful skill that is linked to the effectiveness of the management concerning regulating other's emotions (Niven et al., 2009; Van Kleef, 2009; Zaki \& Williams, 2013; Reeck et al., 2016; Nozaki \& Mikolajczak, 2020). Niven (2016) viewed the aspect of interpersonal from a work-related perspective and describes work-related interpersonal emotion regulation as a deliberate and intentional process by which a person influences another person's personal emotion, i.e., their feelings and experiences. Zaki \& Williams (2013) classified and labeled interpersonal and intrapersonal processes when they described interpersonal emotion regulation as a deliberate and intentional process to change another person's emotional state and or emotional trajectory.

Leaders are expected to assist their subordinates in the management of their work-related emotions, particularly, when managing the emotions of the employees and followers goes beyond their resource capacities (Niven, 2016; Harper, in press). Accordingly, supervisors' moderate employees' reactions at work (Thiel et al., 2012; Haver et al., 2013) by providing supervisory support (Tucker \& Jimmieson, 2017). Supervisors are known to have the skills regarding soothing their subordinates' emotions by interpersonal regulation of the employees concerned (Harper, in press). Being in a position of leadership entails carrying the expectation of being an emotional manager of another person's emotions (George, 2000; Humphrey, 2002) by monitoring their experiences and regulating their negative emotions (Thiel et al., 2012) as well as by inspiring the followers to build interpersonal relationships themselves and providing them with what they need from a leader's perspective (Little et al., 2016).

However, there is a lack of research studies and theoretical models that identify emotional regulatory skills for those who manage other people's emotions. Conversely, there are psychological competencies for promoting the kind of interpersonal effectiveness that is 
associated with an individual's ability to influence and manage other people's emotions (Opengart, 2005). This chapter draws on those associations and the existing theory of emotionas-social information based on the emotion regulation skills-abilities (EASI) model (Van Kleef, 2009). This model postulates that there are clues and cues for how individuals will respond during their social interactions with other persons to regulate their own and others' emotional expressions (Van Kleef, 2009).

This chapter identifies an extrinsic regulator's specific interpersonal skills that they use for interpretation and implementation from clues and cues. Toward this, it draws from Zaki and Williams' (2013) interpersonal emotion regulation mapping processes model, which articulates that the rationale for interpersonal emotion regulation is cause-specific and based on responsedependent actions after an explicit request is made by a support-seeker to an interpersonal extrinsic regulator. Finally, this chapter draws on empirical evidence to build the foundation for model development. Empirical evidence suggests that an individual's perceived interpersonal emotion regulation efficacy is high when certain types of regulatory strategies are selected (Williams et al., 2018) for regulating the emotional expressions of others. Further, it is dependent on the person at the receiving end of the regulation and the events unfolding in a given situation (Pauw et al., 2019). Regulating other person's emotions during a sports competition for instance, is the kind of proxying that is based upon a regulator's belief about what the person's desired emotions should be from the regulator's perspective (Friesen et al., 2019), and a leader's abilities to regulate others' emotions are associated with their belief about what the subordinates' emotional needs are during a crisis. Further, their effectiveness is based on their ability to adapt to those needs (Little et al., 2016).

A conceptional skills model for an interpersonal extrinsic regulator has not been proposed yet, at least not till the work on this chapter was completed. Although several scholars have developed extrinsic processes or a model with a single focus for how an extrinsic regulator behaves, none of these models focus on the skills-abilities aspect. Reeck et al. (2016) The Social Regulatory Cycle (SRC) identifies how a social regulator regulates others during social interactions. Niven et al. (2009) have identified that an extrinsic regulator's interpersonal actions are relatable to the perceived feelings of the person regulated through the Affect Improving and Affect Worsening models. Zaki and Williams (2013) have identified the processes and behaviors that occur as a part of the interpersonal and intrapersonal processes. All notable scholars and study models, however, do not address the specific skills-abilities used and needed by an interpersonal extrinsic regulator.

This chapter discusses The Emotion Regulation Skills-Abilities Model (the ERSA model) and the preliminary skills concerning it. It also discusses the leadership challenges in regulating others' emotions and the usefulness of integrating this aspect to address the leadership crisis, and finally, it discusses the implications of all this. In doing so, this chapter expands on the concept of emotion regulation and learning, in this regard, in the available leadership literature. As such, it contributes to identifying the specific skills of an interpersonal extrinsic regulator. 


\section{The EASI Model}

This model demonstrates that a person's social interaction provides vital social information to them for regulating another person's emotions as an extrinsic regulator. Van Kleef (2009) maintained that the EASI model focuses on the management of social expression. It postulates that social interaction-related information (i.e., cues and clues) be garnered as this information provides the extrinsic regulator with the information necessary for understanding the best way to regulate another person's emotional expression. According to this model, a regulator must accurately infer and correctly utilize their inferences to make appropriate interpretations and judgments about the meanings perceived by the person being regulated including their emotional expressions. The skills needed by a regulator for regulating the emotional expression of others are emotional awareness, ability to make assessments, and accurate interpretation of others' emotional expressions. Van Kleef's (2009) approach discusses how a regulator internalizes the social information received by them and uses these experiences and social information to accurately assess the person being regulated. Further, Van Kleef asserts that a regulator must be highly proficient in their use of emotional intelligence.

Focusing specifically on accuracy in interpretation is relatable to the skills-abilities model that will be discussed later. Van Kleef's description of inferential processes suggests that the actions of a regulator or a person who is interacting with another person are triggered by the actions of those others so much so they change the regulator's behaviors to reflect the needs of the person being regulated. A similar skill was found by Little et al. (2016) in their leader-follower study focused on crisis management in organizations. This key skill has been appropriately labeled by Van Kleef as emotional intelligence ability. Emotional intelligence ability, as a construct and model, has received a lot of attention in the emotional intelligence scientific community and debated much in the abilities versus trait observable models. Resolving this debate is beyond the scope of this chapter's discussion as this chapter addresses this subject from a practical and applied approach.

The ERSA model for which is introduced by this author, identifies the emotional intelligence ability used by a leader for regulating others' emotions whether it is the expressed emotions or an emotional event that occurs through solicitation of social support. Emotional intelligence is the unique set of a leader's overall abilities to interpret another person's behaviors, actions, emotions, and their own emotions, whereby the leaders can apply and implement the received information based upon their understanding that helps in achieving and managing the desired emotional change (Salovey \& Mayer, 1990). The ERSA model an extrinsic regulator skills-abilities go beyond Van Kleef's EASI model that emotional intelligence as an ability for emotional expression to the use of emotional intelligence as an ability to inform the entire social interaction for the benefit of interpersonal extrinsic regulation.

The definition of emotional intelligence, as described with regard to the ERSA model in this chapter, is not limited to the regulation of the emotional expressions of others. Emotionally intelligent leaders can make the most of the information received during social interaction. These leaders have the ability to make appropriate distinctions concerning the information received. For the studies supporting this argument, emotional intelligence is an inclusive construct that 
goes beyond the interpretation of emotional expression (Sullivan, 2011; Nozaki, 2015; Harper, 2015).

The ERSA model goes beyond the value of emotional expressions to identify specific skills-abilities of the interpersonal extrinsic regulator, and in this regard, the ERSA model has several postulates. First, an interpersonal extrinsic regulator uses emotional intelligence abilities that encompass an understanding of the representation of expressions, events, the persons themselves, situations, and environments. This describes the process of an interpersonal regulator using the Insight and Analysis processes (social information, social interaction, emotional intelligence, and experiences relatability). The interpersonal emotion regulation, as expressed for this model, is through the targeted approach of an interpersonal extrinsic regulator who uses it when they are solicited by another person to regulate their emotions (e.g., requesting a boss for help after explaining a situation). If Insight and Analysis are favorable, the interpersonal extrinsic regulator is interested in the social interaction. As mentioned earlier, an interpersonal extrinsic regulator makes use of their emotional intelligence ability in the interpersonal regulatory process. This is done through their explicit and implicit actions. They react to the event or situation that is shared by the person being regulated. The interpersonal extrinsic regulator draws accurate inferences about the interpersonal processes and has correct beliefs about the other person during the interaction (Petrides \& Furnham, 2003; Hall et al., 2016). Their reactions to the solicitation to regulate another person's emotions are nothing but the initiation of the processes that incorporate the skillsabilities model's activation. These processes comprise Solicitation, Insight and Analysis, Proficiency, Decisions, and Regulation Strategies' Selection.

\section{Emotional Intelligence Abilities}

The extrinsic regulation process slows down when emotional intelligence is low. Conversely, a high level of emotional intelligence hinges on the regulator's ability in this area as it supports the extrinsic regulation system (Van Kleef, 2009; Nozaki, 2015; Pauw et al., 2019). In the theory of selfregulation, Carver and Scheier's (1990; 1999) theoretical perspective suggests that self-regulation is an attempt to alter one's emotions to fulfill the one perceives between the current and desired emotional state. Emotional intelligence is an ability that fits within the self-regulation theory and views the concept from a single individual's perspective. However, the construct is viewed from a broader perspective encompassing awareness of others, events, situations, and circumstances. Carver and Scheier's (1990; 1999) theoretical perspective has presented a persuasive argument that individuals can regulate themselves, and oftentimes, they do regulate their own emotions. They self-regulate their emotions because there are discrepancy in what they are feeling and what they desire their emotions to be (Carver and Scheier, 1990; 1999). Subsequently, the field of emotion regulation has developed this understanding beyond an individual's perspective. The current empirical and theoretical findings that have come about further to Carver and Scheier's perspective provide a decisive argument in this regard.

\section{Evolution of the Interpersonal Emotion Regulation Construct}

It can be known through $f$ MRI that a person's brain's functions are at work during their regulation of other people's emotions (Hallam et al, 2014). With regard to the skills used by a regulator, it can be said that most people use the same brain functions to regulate others that they use for regulating themselves, and they do so with the same effectiveness. Through brain imaging, Reeck 
et al. (2016) have demonstrated how a regulator performs the task of social regulation, and they have identified, Identification, Evaluation, and Strategy Selection stages associated with the brain's functioning in this regard. They also have a hypothesis for a particular stage of the brain's functioning in this regard called the Implementation stage.

Campos et al. (2011) have asserted that there is little empirical support for understanding the desires that are being sought to be achieved by those who regulate others. However, the scientific picture regarding this has become a bit clearer. Table 1 presents the findings of these later studies. Broadly speaking, it is now believed that those who regulate others' emotions as their interpersonal extrinsic regulators perceive an emotional discrepancy in the others' current emotional state when compared to the emotional state that they believe the person being regulated should desire or be in.

Table 1. Interpersonal Regulation

\begin{tabular}{|c|c|}
\hline \multicolumn{2}{|l|}{ Empirical Findings } \\
\hline Findings & Authors \\
\hline $\begin{array}{l}\text { Leaders regulated employees' emotions } \\
\text { during a crisis based on what they believed } \\
\text { the employees' emotions should be and what } \\
\text { the employees perceived their leaders' } \\
\text { behaviors should be. }\end{array}$ & Little et al. (2016) \\
\hline $\begin{array}{l}\text { Regulators of others' emotional expressions } \\
\text { filled what they saw as the regulated persons' } \\
\text { discrepancy gaps. Individuals utilized social } \\
\text { information and emotional intelligence to } \\
\text { determine the regulated persons' needs for } \\
\text { regulation. }\end{array}$ & Pauw et al. (2019) \\
\hline $\begin{array}{l}\text { Regulators attempted to regulate their team } \\
\text { members' emotions during sports } \\
\text { competitions based on the regulators' } \\
\text { perceived discrepancy vis-a-vis the regulated } \\
\text { person's current emotional state and what the } \\
\text { regulators believe should be that desired } \\
\text { emotional state of the regulated person. }\end{array}$ & Friesen et al. (2019) \\
\hline $\begin{array}{l}\text { Nurses utilized empathy strategies to regulate } \\
\text { patients. The nurses who had spent a long } \\
\text { time in the nursing service were more } \\
\text { effective and has a higher self-efficacy } \\
\text { measure than those who had been in the } \\
\text { service for less time. }\end{array}$ & Pérez-Fuentes et al. (2019) \\
\hline \multicolumn{2}{|l|}{ Brain Functionality } \\
\hline $\begin{array}{l}\text { fMRI has found that the brain functions in a } \\
\text { certain way during interpersonal emotion } \\
\text { regulation of others. A person whether }\end{array}$ & Hallam et al. (2014) \\
\hline
\end{tabular}




\begin{tabular}{|l|l|}
\hline regulating self or others utilizes similar brain & \\
functions. & \\
\hline A social regulator uses their executive & Reeck et al. (2016) \\
functions when regulating others. They are & \\
proxying for the person being regulated. The & \\
SRC model that has been developed based on & \\
brain imaging depicts the stages in the & \\
executive brain functioning of a social & \\
regulator of others' behaviors. &
\end{tabular}

The findings of the aforementioned and some other studies suggest that emotional regulatory strategies that a regulator of others' emotions/behavior utilizes may not be the sole reason for their effectiveness. It is possible that a regulator's other skills and confidence, as applied during the regulatory process, are also at play. Pérez-Fuentes et al. (2019) point, directly, to the association of confidence and skill in their measure of a nurse's efficacy. Niven et al. (2009) and Niven (2016) propose an interpersonal affect model and theory that demonstrates the different levels of a regulator's competence.

\section{Emotional Regulation Efficacy}

Emotional regulation efficacy is about managing other's emotions. While emotional intelligence has already been described as a vital skill of an interpersonal extrinsic regulator, it also belongs to the Insight and Analysis processes. Another skill that emerges and is recognizable based on recent scientific findings is the ability of self-efficacy to regulate others' emotions. The ERSA model postulates this as an equally necessary and additional skill that operates in an interconnected way. Scholars have opined that being emotionally intelligent and being able to accurately infer an emotional state is necessary for extrinsic regulation (Van Kleef, 2009; Nozaki, 2015; Pauw et al., 2019).

This chapter does not suggest that this is not true. The relationship of the two constructs are complicated, and based on the regulator willingness in terms of the Decisions processes (i.e., considering whether to engage or not engage in the emotional regulatory process) and Proficiency processes (i.e., the skill levels and interpersonal process accuracy with the understanding of the situation and the person being regulated to regulate effectively), these are critical skill factors. The Proficiency processes phase is where the extrinsic regulator is either knowledgeable or lacks the required knowledge. The emotion regulation process cannot occur without the act of engagement on the part of the regulator. This chapter does suggest the following: (1) as a skill, the ability to regulate others' emotions is predicated on the act of the extrinsic regulator deciding whether to perform the regulatory process by engaging; (2) factoring the regulator's skill to perform the regulatory process is based upon their perceived abilities or self-assessment to perform the task of regulating another person's emotions. From a leader's perspective, it is about the decision to engage and/or how to engage if an employee requests for their assistance with solving a problem that has caused emotional distress to the employee.

\section{Integration of Emotional Intelligence and Emotional Regulation of Others-Efficacy}


The ERSA model has three overlapping skill constructs. (Figure 1). An individual's confidence in their ability to regulate the emotions of others has to do with their self-efficacy, leader-follower emotion regulation during a crisis (Little et al., 2016), regulating other peoples' expressions (Pauw et al., 2019), and regulating others' emotions during sports competition (Friesen et al., 2019). Thus, the emotion regulation of other-efficacy and emotional intelligence ability are interconnected skills that overlap each other depending on when they are used by the regulator. The decision to engage becomes an act and is not a skill. The processing of information to get to a decision is where the regulator's skills are utilized. Ideally, high efficacy in terms of one's ability to regulate another person's emotions and high emotional intelligence when operating together lead to a willingness to engage, which is a decision.

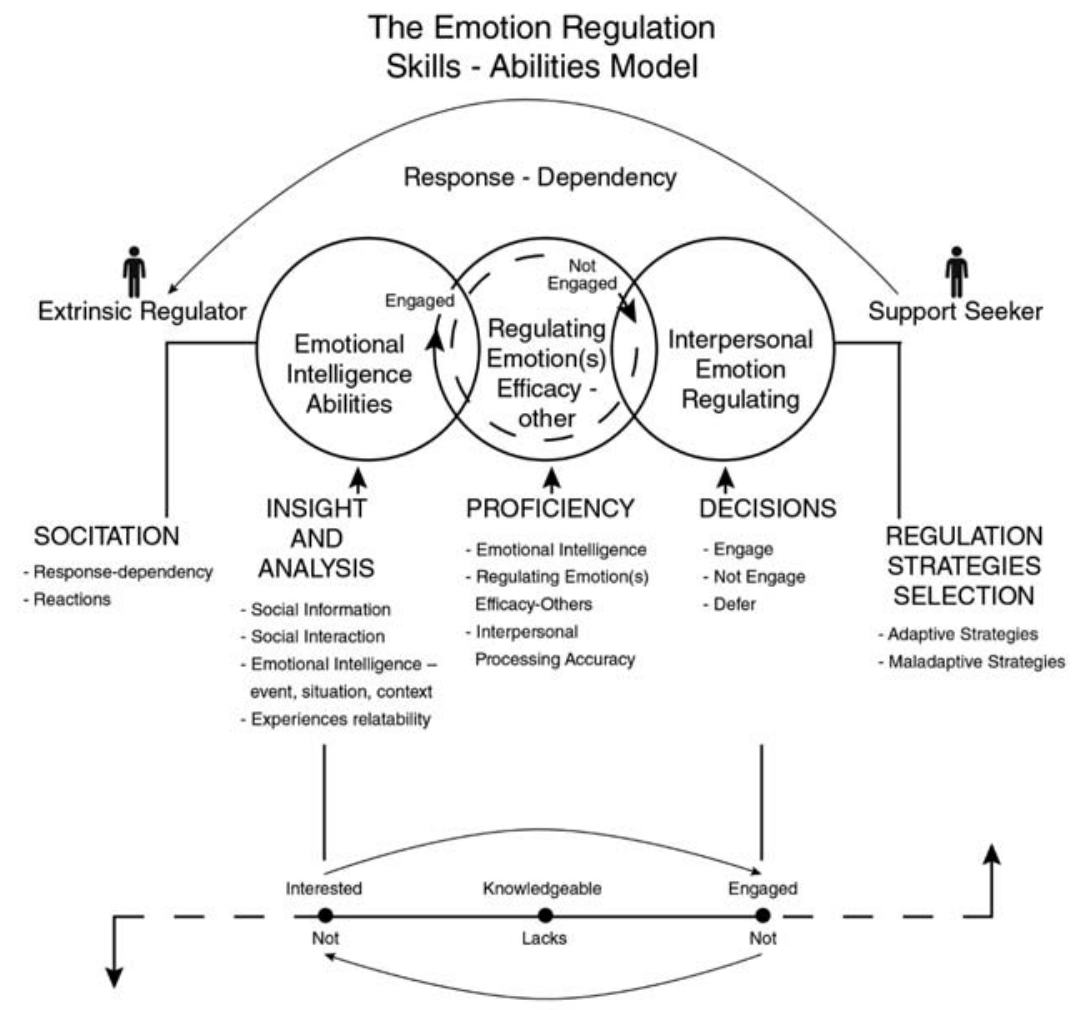

Figure 1. The ERSA Model.

Three overlapping skills-abilities meet when there is a congruence of high emotional intelligence, regulation of other-efficacy, and interpersonal processing accuracy. The extrinsic regulator reacts 
to social response-dependent cues and uses social information to determine the level of involvement based on their skills-abilities levels. Any lack of skills-abilities is a disincentive to engage as an extrinsic regulator. The higher the confidence regarding combining additional skillsabilities, the more it incentivizes engagement and increases the likelihood of regulatory effectiveness. The selection of emotion regulation strategies is based on the application of skillsabilities and person-centered outcomes that are either adaptive or maladaptive strategies.

The ERSA model uses the term leaders interchangeably with the term regulators (Figure 1). This model identifies the initial interpersonal extrinsic regulator's approach. The leader is solicited by a follower or an employee concerning an issue. The leader processes the information received from the employee and responds to them during social interaction. The social interaction involved is a response-dependent process as demonstrated (in Figure 1) by the arrow from the employee to the leader.

A leader can provide emotional modulation (for details, see emotional modulation in the following section) during the social interaction while providing interpersonal emotion regulation. These skills are not limited to comforting, being empathetic, and using prosocial behaviors for gaining a greater understanding of the situation. These skills do not comprise emotional regulation as they can be used unintentionally and do not require the extrinsic regulator to have a goal to regulate. Zaki and Williams (2013) have suggested that there must be response-dependent actions from the regulated person to the extrinsic regulator. Interpersonal response-dependent action describes an action that is taken by the person being regulated to get another person to engage as an extrinsic regulator (e.g., going to a boss or a friend and explicitly asking for help that leads to regulation by that person). The leader in this model is a response-dependent actor after they are solicited to regulate another person's emotion. Expanding the "boss example":

\begin{abstract}
Sally goes to her boss, Larry, because she is overwhelmed with her work assignments. She explains to Larry that she is overwhelmed and that she is stressed. She explicitly asks Larry for help. This request leaves Larry with certain choices and, through his actions, results in him responding to Sally's request. Larry will respond by deploying a choice that he believes is the most appropriate for Sally's situation. Sally's responsedependent approach to Larry and his processing of the information for which he assesses his ability to help and uses the information received as a part of his process to make determinations about how best to proceed.
\end{abstract}

The study by Niven (2016) about interpersonal emotion regulation while at work has reported that a majority of emotion regulation of others occurs in the work environment. Other studies suggest further that work-regulated interpersonal emotion regulation occurs with leaders (Thiel et al., 2012; Niven et al., 2015; Niven, 2016; Little et al., 2016; Vasquez \& Niven, 2020). Figure 1 illustrating the interpersonal extrinsic regulator's approach demonstrates the interconnected and sometimes overlapping skills used by a leader while regulating a situation and how these skills interplay to result in a leader deciding whether to engage and how best to engage once a decision has been made to do so. The potential extrinsic regulator self-assesses their ability to regulate another person's emotion. The working paper titled The Emotion Regulation Skills-Abilities Model features the complete model and explanations in this regard. 
The ERSA model postulates that for an emotionally intelligent regulator the Regulation Selection Strategies are emotional adaptive strategies that are mainly based on their experiences and successes. There is extensive evidence that associates emotional intelligence, as used by a person having high intelligence with self or with others, with sharable skills (Petrides \& Furnham, 2003; Lane et al., 2009; Brackett et al., 2011; Nozaki, 2015; Peña-Sarrionandia et al., 2015). Those with a certain ability are able to share that ability with those who are without that ability (Lane et al., 2009; Williams et al., 2018), and individuals with high emotional intelligence use adaptive emotion regulation while regulating their own emotions (Zomer, 2012; Monaci et al., 2013; PeñaSarrionandia et al., 2015; Megías-Robles, et al. 2019). These studies mentioned previously describe those individuals who utilize adaptive strategies for emotion regulation as those who are likely to use the same skills with others that they used for themselves. Conversely, adaptive emotion regulation strategies are not exclusive. The interpersonal extrinsic regulator uses the Regulation Selection Strategies that may also be maladaptive emotion regulation strategies (that are generally associated with making the receiver's situation worse or are associated with negative psychological symptoms [e.g., making a teammate dislike an opponent in a sports competition to energize the teammate to play better after understanding what motivates them]). All these are not beyond the skills that are used. Niven's et al. (2009) have proposed the affect model that consistently demonstrates a person's affect that can be intentionally worsened to help the person regulate their emotions if it is beneficial for achieving the regulatory goal of deliberately changing the emotional state of the person being regulated. This is also consistent with Carver and Scheier's self-regulation theory. Emotion regulation is about attempting to achieve the desired state. The interpersonal extrinsic regulator may be more willing to use a maladaptive strategy to regulate another person as they are proxying for the person being regulated if such a strategy is perceived by the interpersonal extrinsic regulator as being useful for helping the regulated person achieve the desired emotional state. Therefore, the regulation of others may be less about the emotional regulatory strategies used and more about the interpersonal extrinsic regulator's skills-abilities to regulate others' emotions.

\section{A Leadership Challenge}

As described earlier, adults spend about 7.9 hours daily at work. With regard to the present pandemic situation, its impact on the workplace, at present going forward is not fully known yet. For instance, now, is the time spent at work on interacting with colleagues and customers more, or is it less? Given what was known prior to the pandemic, the amount of time that is usually spent at work has left leaders with the responsibility to manage their employees' emotions. What is also understood about crises and pandemics is that the employees are affected both physically and psychologically with regard to their work-life balance, workload, and work environments, and the stress that all this causes to them affects them adversely on both personal and professional fronts (Faeth \& Kittler 2017; Bader et al., 2019). A workplace leader's interpersonal skills are relevant even during normal times, and they become all the more relevant during a crisis. A pandemic or crisis creates uncertainty for the employees and the organizations alike. During such times, the employees' emotions intensify due to loss of control, uncertainty about the future, lack of employment, and the sudden changes occurring around them that leave things unstructured (Kayes et al., 2013; Dirani et al., 2020). That said, this is also the time when leaders are expected to utilize their unique skills. Undoubtedly, such a situation holds a huge challenge for a leader. 
The leaders are challenged with the understanding of what their skills are and how they could use these skills to help their employees and followers manage work-related stress. The leaders are also challenged in terms of developing their skills and put them into action. During crises what is known is that leaders will likely encounter a situation where their employees and followers have faced more emotional disruptions and even the once better-performing employees may experience problems and/or need the leader's help. As discussed earlier, the employees will likely regulate their emotions at work with others and include their supervisor in the matter (Niven et al., 2015; Niven, 2016). It is estimated that about $98 \%$ of the time people share their emotions with another person (Gross et al., 2006). Identifying one's skills based on the employees' or followers' needs has been referred to as a person-centered approach by Dixon-Gordon et al. (2014). Putting this approach into action can be a challenge for leaders. The skill involved in recognizing their emotional intelligence ability and using this ability to either regulate another person's emotions or defer the engagement are critical skills and actions as observed in "the boss" example of Sally and Larry. Work relationships are not casual, and the extrinsic interpersonal processes utilized at work, as described above, serve to achieve an intended outcome. Larry whose help was solicited by Sally provided emotional support with an intended outcome in mind. The interpersonal extrinsic regulator, Larry, in this instance, was attempting to achieve change in performance by regulating an employee's, i.e., Sally's emotions. Work relationships offer specific understanding about certain experiences that can be commonly shared by both the extrinsic regulator and the support seeker (e.g., work knowledge and culture). These factors interplay in an interpersonal extrinsic regulator's ability to regulate another person's emotional experiences. The ERSA Model identifies the skills that overlap emotional intelligence and emotion regulation other-efficacy for the emotional management of the employee on their request for support. Therefore, the challenge, first, is to build the emotional intelligence and confidence of the leader that they have the requisite skills to help their employees. The good news is that a majority of the leaders have these skills-abilities. By virtue of their position and role, they should have a unique understanding of their work context, the situational context of the employee(s) being regulated, and the work culture that exists.

The ERSA model indicates that a leader must have the necessary awareness and skills. These are developed through social interaction. The information provided to a leader during social interactions that take place in the regular course positions them to be able to regulate another person. These skills are built through being attentive toward the social clues and cues whether they are received implicitly or explicitly. Leaders must also understand the nature of work-related interpersonal extrinsic emotion regulation. The effort in this regard should be purposeful and intended to provide emotional management of another person at a time when such influence on the employee's emotions can cause the work performance to change. The needs of the employee should be weighed against the interpersonal extrinsic regulator's ability to provide emotional regulatory support. The leader's ability to accurately self-assess their tact in terms of providing what is needed by the employees in terms of emotional regulation hinges on whether they can engage in the regulatory interpersonal process or not. The actions a leader takes should amount to an accurate assessment of the self and the situation. The skills to be utilized include emotional intelligence and emotion regulation self-efficacy to regulate another person's emotions. The effectiveness in the use of both these skills is predicated on the leader's efficacy to regulate another person's emotions. This effectiveness is sourced through their abilities of mastery of their 
experiences, vicariousness, social persuasion, and emotional states (Bandura, 1997). Caprara et al. (2008) have provided evidence supporting domain-specific efficacy. Emotion regulation of otherefficacy, as a domain, is a person's perceived capabilities to regulate another person's emotional episode or event or situation whereby the regulator brings about a change in the person's emotional trajectory. Gross and Thompson (2007) describe emotion regulation as an individual's influence on emotions when, where, and how they are experienced and expressed. The interpersonal extrinsic regulator (the leader) serves as a proxy for the employee at the receiving end of the regulation.

\section{Action Taken}

A leader's challenge is their decision to engage or not engage in the emotion regulation process of another person. A leader's challenge is to make accurate inferences about the emotional incident shared and sought to be regulated, the situation concerned and, accordingly, select an appropriate strategy. A leader is expected to be able to assist their employees with emotional management at the workplace when it is beyond the employees' resources/capacities to do so (Niven, 2016; Harper, in press). Dirani et al. (2020) have examined crisis relations during the COVID-19 pandemic, and they have determined the leadership competencies that are best suited for a pandemic. Dirani et al. (2020) point to the need for leaders to be instinctual and to use their insights to provide their employees and organizations with what they need. The action that a leader takes to engage with their employees leads them toward applying a skill that is instinctual and keeps them authentic (Dirani et al., 2020).

\section{Emotional Modulation}

Another notable challenge for a leader is to not confuse emotional modulation with emotion regulation. The processes of emotional modulation may feel like emotion regulation. However, emotional modulation is different as it can be deployed unintentionally and does not necessarily influence emotional change that is goal-driven. Further, it could occur without the use of the interpersonal emotion regulation processes such as response-dependent behavior (Turliuc \& Jitaru, 2019). Zaki and Williams (2013) and Reeck et al. (2016) suggest that emotional modulation is a necessary social skill for promoting interpersonal engagement and for understanding a person, a situation, and emotional events. In the ERSA model these types of skills are a part of the Insight and Analysis processes. These are social skills or lower-level skills of emotion modulation strategies (e.g., empathy, provision of prosocial support, co-regulation, prosocial behaviors, confronting messaging, diffusing support, and provision of material resources). Empirical evidence suggests that a leader's effectiveness at regulating self or others supports individuals to have the different types of emotion regulation strategies at their disposal (Aldao, 2013) or having similar repertories of emotion regulation strategies (Dixon-Gordon et al., 2014).

\section{Skill Activation}

As described earlier, the interpersonal extrinsic regulators of other persons are actually proxying. The emotional regulatory strategies or Regulation Selection Strategies that are activated are those that are person-centered and/or best suited to the person being regulated (Dixon-Gordon et al., 
2014). In other words, there is no such thing as the best strategy for emotion regulation. Also as described earlier, interpersonal emotion regulation is a deliberate and intentional process of influencing another person's emotions which are their feelings and experiences (Niven et al., 2009). The "boss example" involving Sally and Larry describes a person who is in a position of leadership. The leader, Larry, is obligated to assist Sally, his employee, as well as any other person under his leadership. The situation, as described in the example, challenges the leaders. Not only should a leader be willing to engage in the emotional regulation process with another person but it is also necessary that they have the understanding of how to help the individual.

\begin{abstract}
Larry's situational awareness ideally heightens from his learning from Sally during the interaction. This awareness helps him determine if he has the skills to regulate. The ERSA Model identifies the social engagement decision. Larry and any other regulator who is brought into the social regulation process through solicitation would conduct an evaluation of the social interaction and the self. If the proficiency to regulate, emotional intelligence and there is interpersonal process accuracy engagement is likely to occur with effective outcomes.
\end{abstract}

The situation- and context-relevant understanding of the person being regulated links to the selection by the regulator of the emotion regulation strategies (Pauw et al., 2019). Evidence from other empirical studies also, clearly, suggests this. Further, Little et al. (2016) and Friesen et al. (2019) have maintained that it is the leader's skill at regulating another person that matters more than the type of emotional regulatory strategy that has been selected (Webb et al., 2012).

\title{
Regulating Other Person's Emotion Utility
}

The emotion regulation of others is described as an interpersonal emotion process that is intrinsic to the process of regulating one's own emotions (Zaki \& Williams, 2013), or it is an extrinsic process where others are used to help in regulating one's emotions (Zaki \& Williams, 2013). Regulating emotions effectively requires having a repertoire of tools. The discussion that follows focuses on the tools that are utilized to regulate another person's emotions.

Extrinsic emotion regulation occurs when a person is solicited by another person. An extrinsic regulator intervenes using their skills-abilities to interpret and obtain social response-dependent cues to influence the person's emotional change. The decision of engagement. Gross' $(1998,2014)$ model of emotion regulation process describes the sequences of emotion regulation processes when an individual is regulating a situation or event. Gross' model identifies this as the situationselection sequence. In this sequence, the person has some awareness about their selves and the ability to forecast their emotions and the various situations where they would need to engage and cope. Similar, to Gross' sequence, the ERSA model describes the assessment of engagement by the extrinsic regulator who moves toward a decision. The ERSA model identifies five processes and three primary skills where such assessment and decision-making occurs. These processes encompass skills and decisions about whether or not to offer social support through extrinsic regulation another person's emotion. Such decisions are impacted by the level of emotion regulation self-efficacy. Just as emotion regulation self-efficacy in high engagement is likely, emotion regulation self-efficacy in low engagement may also occur; or there may be inaccurate assessment due to lack of engagement or minimum engagement and inaccurate assessment. 
Alternatively, avoidance or deferment of the engagement to others is also possible. At the stage where decisions are to be taken, which is an act, not a skill, the interpersonal extrinsic regulator does one of the following: (a) chooses to proceed, (b) does not proceed, or (c) avoids or defers the decision. When the regulator decides not to proceed or avoids or defers engaging in the interpersonal emotion regulation process, the emotion regulation self-efficacy of the interpersonal extrinsic regulator ranges between no efficacy and low efficacy. Even with emotional regulation as a strategy, the interpersonal extrinsic regulator may lack the ability to intervene. There is either no interest to engage or the lack of knowledge leads to not engaging. When the interpersonal extrinsic regulator proceeds to engage, there is interest to do so, and the regulators are knowledgeable. This means that the emotion regulation self-efficacy is in the high range.

Social interaction is a dynamic process as it is a multi-directional movement of thoughts and social information. After the support seeker's solicitation for help, the regulator uses their skills to self-assess their efficacy to regulate the emotion of others. The onus is on the regulator to draw accurate inferences from the external processes of engagement (Van Kleef, 2009; Reeck et al., 2016; Pauw et al., 2019). The regulator does not have direct access to the support seeker's internal state of mind, but the regulator uses the social information received during the social interactions to inform themselves about their potential responses (Reeck et al., 2016). Van Kleef's (2009) EASI model suggests the value of the regulator of another person possessing emotional intelligence and building awareness when they are socially engaged in a social interaction as this social information serves the purpose of regulating emotions. The ERSA model identifies the skills that can be utilized for this purpose and, hence, need to be developed.

\section{Crisis}

COVID-19 has caused significant disruptions and changes in our lives, economic systems, educational institutions, and workplaces. The World Health Organization (WHO) declared COVID-19 to be a pandemic because of which unprecedented preventive measures had to be taken across the world to stop the spread of the highly contagious virus. These unprecedented steps have involved the people implementing social distancing during their interactions, businesses limiting their operations to a minimum or no physical interaction with customers, and countries and communities imposing massive lockdowns.

Disasters and pandemics create an atmosphere of uncertainty and unpredictability that can cause a range of emotions (fear, anxiousness, sense of loss, loneliness, anger, sadness among others). People are likely to face difficulties in regulating these kinds of emotions (Grimm et al., 2012). Emotion regulation as a skill can, therefore, be an effective tool for successfully functioning in dynamic environments. Emotion regulation can play an important role during a situation like the COVID-19 pandemic as it can help people process what they are feeling and experiencing (Restubog et al., 2020). Several studies have pointed to the advantages of using social support systems in such situations. Having an emotional regulator to assist with emotional management is, undoubtedly, an effective intrapersonal intervention (Niven at al., 2009; Van Kleef, 2009; Zaki \& Williams, 2013; Reeck et al., 2016; Nozaki \& Mikolajczak, 2020). Most of these studies, however, have focused on emotion regulation processes and behaviors as opposed to the skills-abilities of an interpersonal extrinsic regulator. Research on quarantines organized during the SARS, Ebola, 
and Influenza pandemics appears to validate the psychological impact quarantines can have (Preti et al., 2020). Various studies about pandemics that have been described here have emphasized the importance of a certain awareness among individuals who help others manage their emotions during crisis situations. Such awareness is crucial for a regulator to empathetically approach the situation as a regulator with some understanding about the other person's situation. This approach will help the regulator to connect well with the person who has been affected psychologically. As previously discussed, the use of emotion modulation will allow an interpersonal extrinsic regulator to obtain better information and understanding that will assist them with the regulation process. Of course, regulation of one's own emotion is also essential for proper psychological functioning (Gross, 2015) as it is for regulating others' emotions (Zaki \& Williams, 2013).

\section{CONCLUSION}

Recent research points to the advantages of integrating emotional intelligence and emotion regulation (Peña-Sarrionandia et al., 2015) even though the two concepts are distinct. Emotional intelligence is about distinguishing between others' emotions and self and understanding the usefulness of information to change emotions. Emotion regulation is related to the processes of regulating emotions in different ways to either control or not control the emotions a person wishes to have. The ERSA model posits an integration of these two concepts into a single conceptual skills-abilities model for a person who is an extrinsic regulator of others. The ERSA model proposes five processes and three primary skills to approach the regulation of others' emotions. These processes are Solicitation, Insight and Analysis, Proficiency, Decisions, and Regulation Selection Strategies. The three skills of the model are: emotion regulation of others-efficacy, emotional intelligence as an ability, and the utilization of these two skills in an emotion regulation process of managing others' emotions. In this chapter this model has been adapted to what a leader actually does (see "boss examples"). The implications are that these three dominant skills are necessary for interpersonal emotion regulation of others whether it is done in the role of a leader or not emerging evidence suggests that it is not the selection of emotional regulatory strategies that leads to effectiveness (Webb et al., 2012), but the actual skills that are used by the regulator of other's emotions. The latter are more important in the intervening processes concerned. The selection of emotional regulatory strategies may merely be a reflection of the skills-abilities used to achieve the desired results from an interpersonal extrinsic process. The ERSA model is, thus, a new preliminary skills model that presents the skills and processes of an extrinsic regulator in a single conceptual framework. This framework can help us understand and develop the necessary skills in leaders who are proxies for their employees and followers in the employees' / followers' emotional management. 


\section{REFERENCES}

Aldao, A. (2013). The future of emotion regulation research: Capturing context. Perspectives on Psychological Science, 8(2), 155-172. https://doi.org/10.1177/1745691612459518

Bader, A. K., Reade, C., \& Froese, F. J. (2019). Terrorism and expatriate withdrawal cognitions: The differential role of perceived work and non-work constraints. International Journal of Human Resource Management, 30(11), 1769-1793. https:// doi.org/10.1080/09585192.2016.1233448

Bandura, A. (1997). Self-efficacy: The exercise of control. W H Freeman/Times Books/ Henry Holt \& Co.

Bureau of Labor Statistics, (2020). American time use survey - 2019 Results. News release. Bureau of Labor Statistics. US Department of Labor

Brackett, M. A., Rivers, S. E., \& Salovey, P. (2011). Emotional intelligence: Implications for personal, social, academic, and workplace success. Social and Personality Psychology Compass, 5(1), 88-103. https:// doi.org/10.1111/j.1751-9004.2010.00334.x

Campos, J. J., Walle, E. A., Dahl, A., \& Main, A. (2011). Reconceptualizing emotion regulation. Emotion Review, 3(1), 26-35. https:// doi.org/10.1177/1754073910380975

Caprara, G. V., Di Giunta, L., Eisenberg, N., Gerbino, M., Pastorelli, C., \& Tramontano, C. (2008). Assessing regulatory emotional self-efficacy in three countries. Psychological Assessment, 20(3), 227-237. https://doi.org/10.1037/10403590.20.3.227

Carver, C. S., \& Scheier, M. F. (1990). Origins and functions of positive and negative affect: A control-process view. Psychological Review, 97(1), 19-35. https://doi.org/10.1037/0033-295X.97.1.19

Carver, C. S., \& Scheier, M. F. (1999). Stress, coping, and self-regulatory processes. In L. A. Pervin \& O. P. John (Eds.), Handbook of personality: Theory and research (pp. 553575). Guilford Press.

Dirani, K. M., Abadi, M., Alizadeh, A., Barhate, B., Garza, R. C., Gunasekara, N., Ibrahim, G., \& Majzun, Z. (2020). Leadership competencies and the essential role of human resource development in times of crisis: A response to Covid-19 pandemic. Human Resource Development International, 23(4), 380-394.

Dixon-Gordon, K. L., Chapman, A. L., Weiss, N. H., \& Rosenthal, M. Z. (2014). A Preliminary examination of the role of emotion differentiation in the relationship between borderline personality and urges for maladaptive behaviors. Journal of Psychopathology and Behavioral Assessment, 36(4), 616-625. https://doi.org/10.1007/s10862-014-9423-4

Faeth, P. C, \& Kittler, M. (2017). How do you fear? Examining expatriates' perception of danger and its consequences. Journal of Global Mobility, 5(4), 391-417. https://doi.org/10.1108/JGM-11-2016-0063 
Friesen, A., Stanley, D., Devonport, T., \& Lane, A. M. (2019). Regulating own and teammates' emotions prior to competition. Movement E Sport Science E Motricité, $105,5-15$.

George, J. M. (2000). Emotions and leadership: The role of emotional intelligence. Human Relations, 53, 1027-1055. doi:10.1177/0018726700538001

Grimm, A., Hulse, L., Preiss, M., \& Schmidt, S. (2012). Post- and peritraumatic stress in disaster survivors: An explorative study about the influence of individual and event characteristics across different types of disasters. European Journal of Psychotraumatology, 3, https:// doi.org/10.3402/ejpt.v3i0.7382

Gross, J. J. (1998). The emerging field of emotion regulation: An integrative review. Review of General Psychology, 2(3), 271-299. http:/ / dx.doi.org/ 10.1037/1089-2680.2.3.271

Gross, J. J. (2014). Emotion regulation: Conceptual and empirical foundations. In J. J. Gross (Ed.), Handbook of emotion regulation (pp. 3-20). The Guilford Press.

Gross, J. J. (2015). Emotion regulation: Current status and future prospects. Psychological Inquiry, 26(1), 1-26. https:// doi.org/10.1080/1047840X.2014.940781

Gross, J. J., \& Thompson, R. A. (2007). Emotion regulation: Conceptual foundations. In J. J. Gross (Ed.), Handbook of emotion regulation (pp. 3-24). The Guilford Press.

Gross, J. J., Richards, J. M., \& John, O. P. (2006). Emotion regulation in everyday life. In D. K. Snyder, J. Simpson, \& J. N. Hughes (Eds.), Emotion regulation in couples and families: Pathways to dysfunction and health (pp. 13-35). American Psychological Association. https://doi.org/10.1037/11468-001

Hall, L. H., Johnson, J., Watt, I., Tsipa, A., \& O'Connor, D. B. (2016). Healthcare staff wellbeing, burnout, and patient safety: A systematic review. PloS one, 11(7), e0159015. https://doi.org/10.1371/journal.pone.0159015

Hallam, G. P., Webb, T. L., Sheeran, P., Miles, E., Niven, K., Wilkinson, I. D., Hunter, M. D., Woodruff, P. W. R, Totterdell, P., \& Farrow, T. F. D. (2014) The neural correlates of regulating another person's emotions: an exploratory fMRI study. Frontiers in Human Neuroscience, 8(376). http:/ / dx.doi.org/10.3389/fnhum.2014.00376

Harper, D. S. (in press). Interpersonal emotion regulation while at work: A test of differences. International Journal of Work Organisation and Emotion

Harper, D. S. (2016). Correctional executives' leadership self-efficacy and their perceptions of emotional intelligence. American Journal of Criminal Justice, 41(4), 765-779. https://doi.org/10.1007/s12103-015-9319-1

Haver, A., Akejodet, K., \& Furunes, T. (2013). Emotional regulation and its implications for leadership: An integrative review and future research agenda. Journal of Leadership and Organizational Studies, 20, 287-303. DOI: 10.1177/ 1548051813485438.

Humphrey, R.H. (2002).The many faces of emotional leadership. The Leadership Quarterly, 13, 493-504.

Kayes, D. C., Allen, N., \& Self, N. (2013). Integrating learning, leadership, and crisis in management education: Lessons from army officers in Iraq and Afghanistan. 
Journal of Management Education, 37(2), 180-202. https:// doi.org/10.1177/1052562912456168

Lane, A. M., Thelwell, R. C., Lowther, J., \& Devonport, T. J. (2009). Emotional intelligence and psychological skills use among athletes. Social Behavior and Personality: An International Journal, 37(2), 195-202.

Little, L. M., Gooty, J., \& Williams, M. (2016). The role of leader emotion management in leader-member exchange and follower outcomes. The Leadership Quarterly, 27(1), 85-97. https:/ / doi.org/10.1016/j.leaqua.2015.08.007

Megías-Robles, A., Gutiérrez-Cobo, M. J., Gómez-Leal, R., Cabello, R., Gross, J. J., \& Fernández-Berrocal, P. (2019). Emotionally intelligent people reappraise rather than suppress their emotions. PloS one, 14(8), e0220688.

Mintzberg, H. (1973). The nature of managerial work. New York, NY: Harper \& Row.

Monaci, M. C., Scacchi, L., Posa, M., \& Trentin, R. (2013). Peer pressure and alcohol consumption among university students: The moderating effect of emotional intelligence. Bollettino di Psicologia Applicata, 267, 17-31.

Niven, K. (2016). Why do people engage in interpersonal emotion regulation at work? Organizational Psychology Review, 6(4), 305-323. https:// doi.org/10.1177/2041386615612544

Niven, K., Garcia, D., van der Löwe, I., Holman, D., \& Mansell, W. (2015). Becoming popular: interpersonal emotion regulation predicts relationship formation in real life social networks. Frontiers in Psychology, 6, 1452. https://doi.org/10.3389/fpsyg.2015.01452

Niven, K., Totterdell, P., \& Holman, D. (2009). A classification of controlled interpersonal affect regulation strategies. Emotion, 9(4), 498-509. https://doi.org/10.1037/a0015962

Nozaki Y. (2015). Emotional competence and extrinsic emotion regulation directed toward an ostracized person. Emotion, 15(6), 763-774. https://doi.org/10.1037/emo0000081

Nozaki, Y., \& Mikolajczak, M. (2020). Extrinsic emotion regulation. Emotion, 20(1), 10-15. https:// doi.org/10.1037/emo0000636

Opengart, R. (2005). Emotional intelligence and emotional work: Examining constructs from an interdisciplinary framework. Human Resource Development Review, 4(1), 49-62

Pauw, L. S., Sauter, D. A., van Kleef, G. A., \& Fischer, A. H. (2019). Stop crying! The impact of situational demands on interpersonal emotion regulation. Cognition $\mathcal{E}$ Emotion, 33(8), 1587-1598. https://doi.org/10.1080/02699931.2019.1585330

Peña-Sarrionandia, A., Mikolajczak, M., \& Gross, J. J. (2015). Integrating emotion regulation and emotional intelligence traditions: A meta-analysis. Frontiers in Psychology, 6, 160. https://doi.org/10.3389/fpsyg.2015.00160

Pérez-Fuentes, M. d. C., Molero Jurado, M. d. M., del Pino, R. M., \& Gázquez Linares, J. J. (2019). Emotional intelligence, self-efficacy and empathy as predictors of overall self-esteem in nursing by years of experience. Frontiers in Psychology, 10, 2035. https://doi.org/10.3389/fpsyg.2019.02035 
Petrides, K. V., \& Furnham, A. (2003). Trait emotional intelligence: Behavioural validation in two studies of emotion recognition and reactivity to mood induction. European Journal of Personality, 17(1), 39-57. https:// doi.org/10.1002/per.466

Preti, E., Di Mattei, V., Perego, G., Ferrari, F., Mazzetti, M., Taranto, P., Di Pierro, R., Madeddu, F., \& Calati, R. (2020). The psychological impact of epidemic and pandemic outbreaks on healthcare workers: Rapid review of the evidence. Current Psychiatry Reports, 22(8), 43. https://doi.org/10.1007/s11920-020-01166-Z

Reeck, C., Ames, D. R., \& Ochsner, K. N. (2016). The social regulation of emotion: An integrative, cross-disciplinary model. Trends in cognitive Sciences, 20(1), 47-63. https://doi.org/10.1016/j.tics.2015.09.003

Restubog, S. L. D., Ocampo, A. C. G., \& Wang, L. (2020). Taking control amidst the chaos: Emotion regulation during the COVID-19 pandemic. Journal of Vocational Behavior, 119, 103440. https://doi.org/10.1016/j.jvb.2020.103440

Salovey, P., \& Mayer, J. D. (1989-1990). Emotional intelligence. Imagination, Cognition and Personality, 9(3), 185-211. https://doi.org/10.2190/DUGG-P24E-52WK-6CDG

Sullivan, R. (2011). Deploying financial emotional intelligence. Financial Analysts Journal, 67(6), 4-7. https://doi.org/10.2469/faj.v67.n6.6

Stajkovic, A. D. (2006). Development of a core confidence-higher order construct. Journal of Applied Psychology, 91(6), 1208-1224. https://doi.org/10.1037/00219010.91.6.1208

Stajkovic, A. D., Lee, D., Greenwald, J. M., \& Raffiee, J. (2015). The role of trait core confidence higher-order construct in self-regulation of performance and attitudes: Evidence from four studies. Organizational Behavior and Human Decision Processes, $128,29-48$

Thiel, C. E., Bagdasarov, Z., Harkrider, L., Johnson, J. F., \& Mumford, M. D. (2012). Leader ethical decision-making in organizations: Strategies for sensemaking. Journal of Business Ethics, 107(1), 49-64. https:/ / doi.org/10.1007/s10551-012-1299-1

Tucker, M. K., \& Jimmieson, N. L. (2017). Supervisors' ability to manage their own emotions influences the effectiveness of their support-giving. Journal of Personnel Psychology, 16(4), 195-205. https:// doi.org/10.1027/1866-5888/a000189

Turliuc, M. N., \& Jitaru, M. (2019). Interpersonal emotion regulation - A concept in search of clarification. Revista de Psihologie, 65(4), 281-291.

Van Kleef, G. A. (2009). How emotions regulate social life: The emotions as social information (EASI) Model. Current Directions in Psychological Science, 18(3), 184188. https://doi.org/10.1111/j.1467-8721.2009.01633.x

Vasquez, C., \& Niven, K. (2020). Leader interpersonal emotion regulation and follower $\begin{array}{lllll}\text { performance. Journal of Personnel Psychology, 19(2), } 97 . & \end{array}$ https://doi.org/10.1027/1866-5888/a000249

Webb, T. L., Miles, E., \& Sheeran, P. (2012). Dealing with feeling: A meta-analysis of the effectiveness of strategies derived from the process model of emotion regulation. Psychological Bulletin, 138(4), 775-808. https:// doi.org/10.1037/a0027600

Williams, W. C., Morelli, S. A., Ong, D. C., \& Zaki, J. (2018). Interpersonal emotion regulation: Implications for affiliation, perceived support, relationships, and well- 
being. Journal of Personality and Social Psychology, 115(2), 224-254. https://doi.org/10.1037/pspi0000132

Zaki, J., \& Williams, W. C. (2013). Interpersonal emotion regulation. Emotion, 13(5), 803810. https://doi.org/10.1037/a0033839

Zomer L. M. A. (2012). The relationships among emotional intelligence, gender, coping strategies, and well-being in the management of stress in close interpersonal relationships and the workplace (Unpublished doctoral dissertation). University of Toronto. 


\title{
Chapter 6
}

\section{The Impact of Covid-19 on the Financial Contagion of Real Economy: A Sectoral Analysis}

\author{
Deniz Erer, Elif Erer
}

\begin{abstract}
COVID-19 pandemia first emerged in Wuhan, China in December 2019 and it has turned into a global pandemic by spreading around the world in a short time. This pandemic disaster has lead to uncertainty and anxiety in financial markets and have created pressure on real economy. This situation is predicted to cause severe economic crisis because of stopping suddenly an important part of economic activities. This paper investigates financial contagion of aggregate regional stock markets and regional real economy sectors over the daily period of the 02.01.2015-03.06.2020 including COVID-19 pandemia and different phases of the crisis in developing and developed countries. Two channels of contagion are used, one of which is contagion of regional stock market and other is contagion of regional real economy sector. For this purpose, dynamic conditional correlation models are applied and ARMA(1,1)FIGARCH(1,1)-DCC model is determined as most appropriate model. The findings show that dynamic conditional correlation between world aggragate stock index (MSCI) and regional financial and non-financial sector indices augmented significantly during the periods of crisis and COVID-19 pandemia. COVID-19 pandemia lead to rise financial contagion effects of regional stock markets and regional real economy sectors. Brazil has the highest magnidute of increase in dynamic conditional correlation due to COVID-19 pandemia. Financial sector is mostly affected by COVID-19 pandemia in China, France, Italy and United Kingdom while energy sector in Brazil and Turkey. These results imply that expectations regarding to economic activity will deteriorated because of the fact that world trade volumes has fallen away due to COVID-19 pandemia lead to decrease aggregate regional stock markets and sectors. Therefore, this refers that there is a shift in risk appetite of investors. Unlike previous financial shocks, the COVID-19 pandemia has caused a fall in world economic activity simultaneously. Secondly, uncertainity related to so-called pandemia has still contiuned. Finally, global financial system affects directly non-financial sectors.
\end{abstract}

Keywords: COVID-19, pandemia, financial contagion, real economy, multivariate GARCH models, stock markets, developed countries, devoloping countries. 


\section{INTRODUCTION}

Financial markets move based on the state of the real economy, which impacts the financial economy. Thus, understanding of the connection between the economies in question is of importance in terms of stability and efficiency of the economic system. Due to increasing financial instability after especially global financial crisis, enermous resources transfer from manufacturing sector to financial sector has become one of specialities of economic system (Suzuki, Namatame and Aruka,2014). Therefore, it is important to investigate for the financial contagion on real economy.

There is no consensus on "contagion" in the finance litarature. According to some theorists, financial contagion is a theory stating that small shocks initially affect only a certain area of economy or several institutions, and then spread to the rest of financial sector and big economies. Other theorists indicate that financial contagion is only the spread of financial stress (Kolb, 2011: 4; Pericoli ve Sbracia, 2003: 573; Forbes ve Rigobon, 2002). Financial instability causes increase in volatility and unertainty, which states that investors take more risks in the financial uncertainty periods (Sharpe, 1964, Lintner,1965, Black, 1972).

In contagion literature, most of the studies focused on the connection between stock markets (Forbes and Rigobon, 2002; Bekaert et. al., 2014; Chandar et. al., 2009; Dungey et. al., 2010, Ahmad et. al., 2013; Dimitriou et. al.,2013; Apergis et. al., 2019). However, contagion may also emerge between financial sector and real sector across countries. But, the number of the studies investigating the financial contagion on real economy are rather limited (Bekaert et. al., 2014; Baur, 2012, 2013; Dimitriou et. al., 2013; Kenourgios and Dimitriou, 2015). Baur (2013) examined the the contagion effect of financial market on real economy. He used data as to total and sub-sector stock market indices. Bekaert et. al. (2014) examined financial contagion effect of global financial crisis by considering 55 countries and 415 sector equity portfolios for each country, and they exhibited that financial contagion emerged via domestic channels. Baur (2012) analyzed financial contagion on real economy using data covering 25 stock market and their sector indices and indicated that financial contagion occured in only some sectors and any country and sector didn't be affected adversely. Kenourgios and Dimitriou (2015) investigated the contagion from financial markets to real sector through different channels for developing and developed countries and 10 sectors. From the analysis, it was found that financial contagion on real economy across regional stock markets in especially developing countries. Also, consumer goods, healthcare and technology are evidenced to be the sectors less affected.

Financial crisis and COVID-19 pandemic make important problems a current issue in terms of how financial systems are designed and represented and what the consuquences of so-called conceptions may be.

A number of public health and social measures, such as isolating, contract tracing, applications of quarantine, social distancing, declaring curfews, border shutdowns, domestic travel restriction, have been taken by national governments and international institutions due to COVID-19 which first emerged in Wuhan, China in December 2019 and has become a global pandemic by spreading around the world in a short time (World Health Organization, April 2020). So-called measures have lead to uncertainty and anxiety in financial markets and have created pressure on real economy. This situation is predicted to cause severe economic crisis because of stopping suddenly an important part of economic activities (Winston, 2020; Kuckertz et.al., 2020; Segal and Gerstel, 2020). Fiscal and monetary authorities have made a number of ongoing interventions to stimulate economies. The governments have announced fiscal stimulus packages. Central banks have decreased policy interest rates and reserve requirements and increased liquidity facilities (Congressional Research Service, 2020; IMF, 2020). 
Within this framework, we investigate how COVID-19 pandemia impacts the contagion between financial market and real economy in the paper. The literature focused on the economic impacts of COVID-19 has started to grow shiftly (Baker et. al., 2020; Conlon and McGee, 2020; Corbet et al., 2020; Kristoufek, 2020; Sharif et al., 2020; McKibbin and Fernando, 2020; Ramelli and Wagner, 2020; Zhang et al., 2020). However, there are rare studies focused on the financial contagion on real economy the periods of both financial crisis and pandemics such as SARS, MERS, COVID-19 (Gai and Kapadia, 2010; Peckham, 2013, Akhtaruzzamana et. al., 2020). The study aims to fulfill this gap by examining that financial contagion in financial and non-financial sectors during the periods of crisis and COVID-19 pandemia.

We investigated two channels of contagion following Baur (2012) and Kenourgios and Dimitriou (2015). First channel is contagion of regional stock market. In this channel, increase in dynamic conditional correlation between regional stock market and world aggragate stock market index (MSCI) in both the crisis period and COVID-19 pandemi period by comparison with calm period indicates financial contagion. Second channel is contagion of regional real economy sector. According to this channel, increase in dynamic conditional correlation between regional non-financial sector stock index and MSCI index in both the crisis period and COVID-19 pandemi period presents the financial contagion on real economy.

The empirical results demonstrate that dynamic conditional correlation between world aggragate stock index (MSCI) and regional financial and non-financial sector indices augmented significantly during the periods of crisis and COVID-19 pandemia. The magnidute of increase in dynamic conditional correlation due to COVID-19 pandemia is higher in Brazil because of being second country with the highest number of cases. Financial sector is mostly affected by COVID-19 pandemia in China, France, Italy and United Kingdom while energy sector in Brazil and Turkey.

The remainder of the paper is organized as follows. Section 2 indicates empirical methodology including multivariate DCC-GARCH models. Section 3 introduces the data covering financial and non-financial sector indices and crisis period definition. Section 4 presents the estimation results. Finally, Section 5 summarizes conclusions.

\section{METHODOLOGY FRAMEWORK}

This section exhibits the multivariate FIGARCH-DCC model. This model is composed of twostage estimation of the conditional covariance matrix. Firstly, univariate GARCH models are estimated for each financial and non-financial sector stock indices, and then the estimates of conditional variance are obtained from univariate GARCH model.

$\operatorname{GARCH}(\mathrm{p}, \mathrm{q})$ model purposed by Bollerslev (1986) can be stated as

$$
h_{t}^{2}=\omega+\sum_{i=1}^{p} \alpha_{i} \varepsilon_{t-i}^{2}+\sum_{j=1}^{q} \beta_{j} h_{t-j}^{2}+\varepsilon_{t}
$$

$h_{t}^{2}$ indicates conditional variance.

$\mathrm{GARCH}(\mathrm{p}, \mathrm{q})$ model can be rewrited using the lag operator $(\mathrm{L})$ as follows:

$$
\begin{gathered}
h_{t}^{2}=\omega+\alpha(L) \varepsilon_{t}^{2}+\beta(L) h_{t}^{2} \\
\alpha(L)=\alpha_{1} L+\alpha_{2} L^{2}+\cdots+\alpha_{q} L^{q} \text { and } \alpha(L)=\beta_{1} L+\beta_{2} L^{2}+\cdots+\beta_{p} L^{p}
\end{gathered}
$$

FIGARCH model proposed by Baillie, Bollerslev and Mikkelsen (1996) allows to long memory in modelling volatility. 
FIGARCH(p,d,q) model as follows:

$$
h_{t}^{2}=w[1-\beta(L)]^{-1}+\left\{1-[1-\beta(L)]^{-1} \emptyset(L)(1-L)^{d}\right\} \varepsilon_{t}^{2}
$$

$(1-L)^{d}$ is the first difference operator. Fractional differerence parameter enables to model the long run dependence. The main characteristic of $\operatorname{FIGARCH}(\mathrm{p}, \mathrm{d}, \mathrm{q})$ is that the so-called model is not stationary as $\mathrm{d}>1 . h_{t}^{2}=w^{*}+\sum_{i=1}^{\infty} \lambda_{i} L^{i} \varepsilon_{t}^{2}, \quad 0 \leq d \leq 1 . \quad w>0, \beta_{1}-d \leq \emptyset_{1} \leq \frac{2-d}{3}$ and $d\left(\emptyset_{1}-\frac{1-d}{2}\right) \leq \beta_{1}\left(\varnothing_{1}-\beta_{1}+d\right)$ are requied conditions to provide positive conditional variance of FIGARCH $(1, \mathrm{~d}, 1)$ model.

DCC-GARCH model proposed by Engle (2002) is designated by regarding dynamic maxtrix process. DCC-GARCH model can be defined as follows:

$$
H_{t}=D_{t} C_{t} D_{t}
$$

$D_{t}=\operatorname{diag}\left(h_{11 t}^{\frac{1}{2}} \ldots \ldots h_{N N t}^{\frac{1}{2}}\right), h_{i i t}$ is described as the conditional variance from $\operatorname{FIGARCH}(1, \mathrm{~d}, 1)$ model and $C_{t}=\left(1-\theta_{1}-\theta_{2}\right) C+\theta_{1} \delta_{t-1}+\theta_{2} C_{t-1} \cdot \theta_{1}$ ve $\theta_{2}$ are supposed not to be negative parameters meeting $\theta_{1}+\theta_{2}<1, C=\left\{p_{i j}\right\}$ is time-invariant symmetric $\mathrm{NxN}$ positive definite parameter matrix with $p_{i i}=1$. Also, $\delta_{t-1}$ is the $\mathrm{NxN}$ matrix of which elements consist of the lagged values of residuals $\varepsilon_{t}$. FIGARCH $(1, \mathrm{~d}, 1)$ model can be stated extendedly as follows:

$h_{t}^{2}=(1-\alpha-\beta) S+\alpha \varepsilon_{t-1} \varepsilon_{t-1}^{\prime}+\beta h_{t-1}^{2}$

$\alpha$ and $\beta$ indicate respectively positive and non-negative parameters across the condition of $\alpha+\beta<1$. $S$ presents unconditional correlation matrix of standardized residuals $\varepsilon_{t}$.

\section{DATA}

The data includes daily open prices of aggregate stock market index and six sector stock indices for three developing countries (Turkey, China, Brazil) and four developed countries (United Kingdom, United States, Italy, France). The sector stock indices are material, industry, financials, energy, technology, telecomunications. Also, the so-called countries are among first twelve countries in terms of spread rate of COVID-19 cases. The data obtained from investing.com covers the period of 3st January 2015-3th June 2020. For each stock index, the return is calculated $r_{t}=\log \left(\frac{p_{t}}{p_{t-1}}\right)$ where $p_{t}$ represents the price on day $\mathrm{t}$.

Descriptive statistics for the returns of seven aggregate stock market indices during full sample period (02.01.2015-03.06.2020) and COVID-19 pandemic period (01.01.2020-03.06.2020) are shown in Table 1. As seen in Table 1, COVID-19 pandemic led to decrease mean returns for all stock market indices exception of China and to increase standart deviations for all aggregate stock market indices. According to skewness and kurtosis, all returns have fat tails and leptokurtic ditribusiton. The results of ARCH-LM test for the squared residuals show the availability of heteroskedasticity for all returns. The results of Geweke and Porter-Hudak, Robinson and Henry and R/S tests on squared returns applied to test long memory indicate that null hypothesis which represents no long memory are rejected for all returns at the $5 \%$ level. Therefore, we used ARMA(2,2)-FIGARCH-DCC model with student-t distributed errors in order to acquire volatility clustering, leverage and long memory effects. 
Table 1. Descriptive statistics for stock market indices

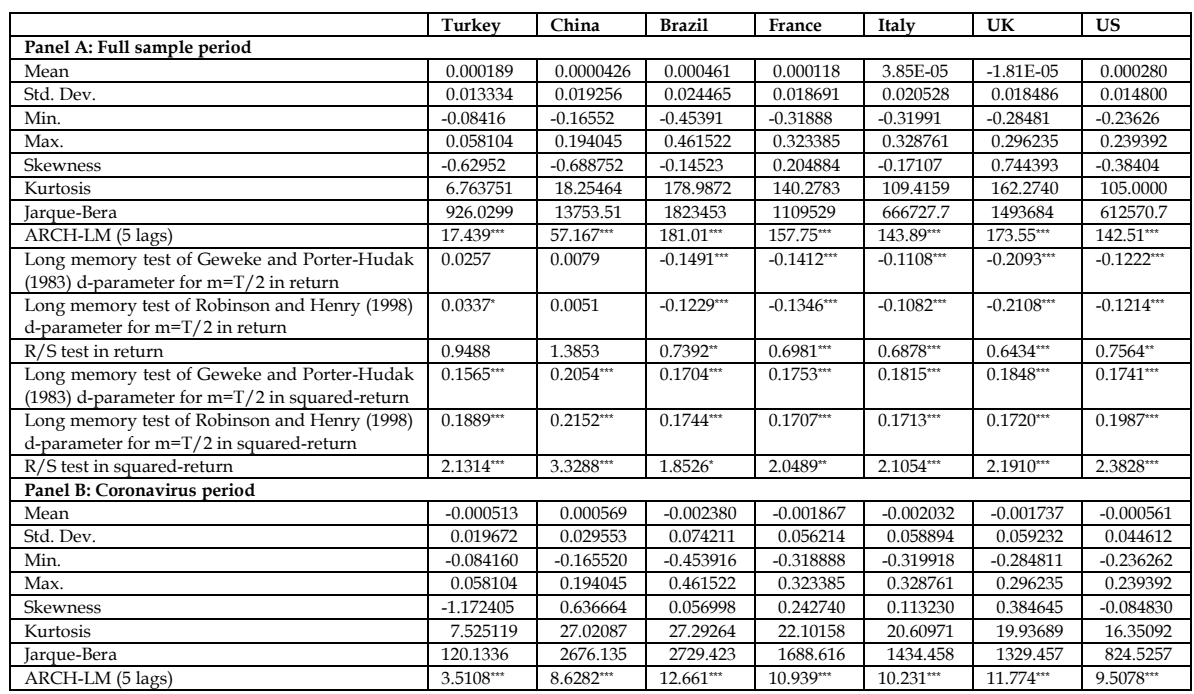

Notes: ${ }^{*}$, ${ }^{\text {*t }}$ and ${ }^{\text {twt }}$ represent $10 \%, \% 5$ and $\% 1$ statistical signifance, respectively. Full sample period covers 02.01.2015-06.03.2020 and coronavirus period covers 01.01.2020-06.03.2020.
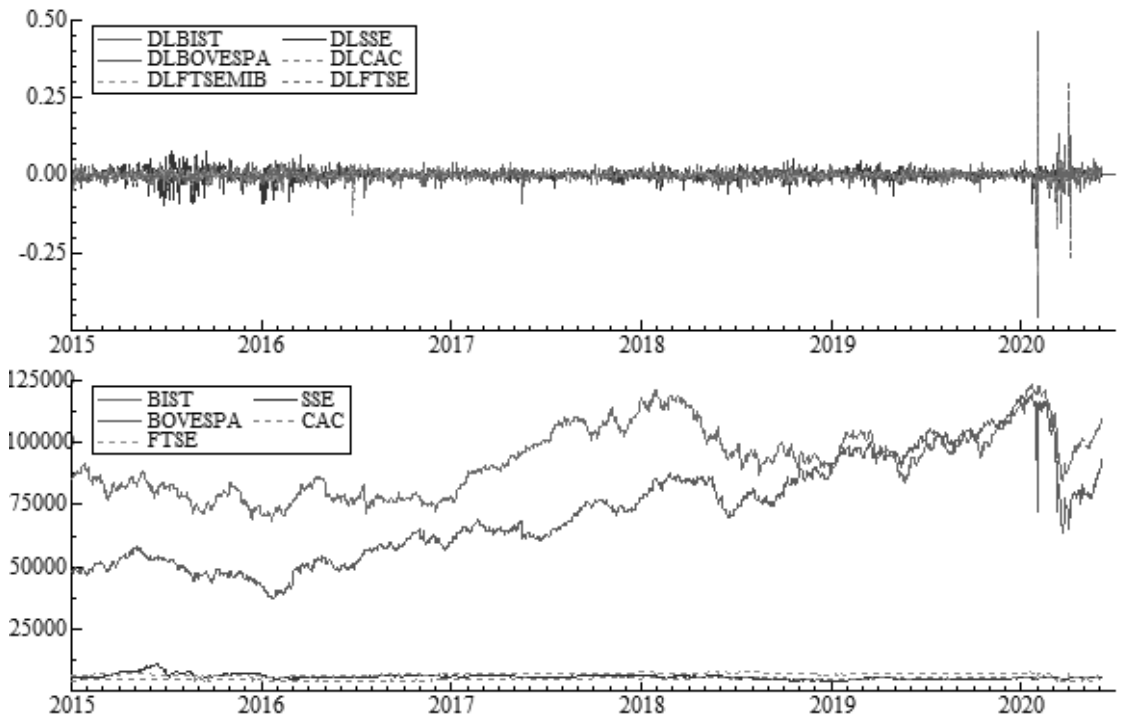

Figure 1: Return series and close prices of stock market indices during the period of 01.01.2015-03.06.2020.

This figure indicates the progress of the stock market indices in the developing and develop countries, which are Turkey stock index, China stock index, Brazil stock index, France stock index, Italy stock index and United Kingdom stock index. 
Figure 1 exhibits return series and close prices of stock market indices for each countries over the sample period (2015-2020). As seen in Figure 1, there are strong co-movement among stock market indices and volatilities of all stock market returns increased in 2016 because of global recession anxieties due to EU elections, Brexit aggrement, declining economic growth in China. Similarly, volatility in stock market of each country has arised due to economic uncertainty from COVID-19 pandemia.

We defined regimes of excess volatility, which are crisis period and COVID-19 pandemi period, through Markov Switching Dynamic Regression (MS-DR) model. The model in question is extended of Markov switching regression model (MS) proposed by Hamilton (1989). MS-DR model considers endogenous structural breaks, and hereby, the begining and end dates of the crisis can be determined endogenously. We use the world aggregate stock market (MSCI) index as a source of contagion due to supposing that the crisis lead to shift in global risk appetite of investors.

We generate the conditional volatilites for MSCI index returns using ARMA(2,2)FIGARCH $(1,1)$ model over the period of 01.01.2015-03.06.2020. The MS-DR model suppose the existence of stable regime (low values of conditional volatilities) and volatile regime (high values of conditional volatilities) for MSCI index. The smoothed regime probabilities shown in Figure 2 indicate that volatile regimes of MSCI index are situated in both the crisis period and COVID-19 period.

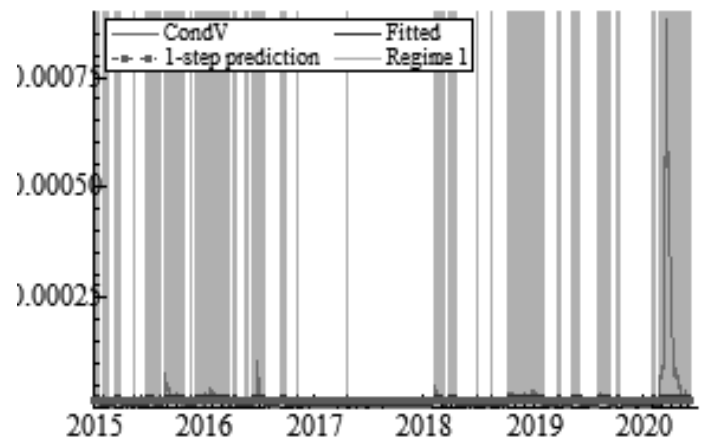

Figure 2. Smoothed regime probabilites based on conditional volatilities. This figure indicates the volatile regimes for MSCI index. The grey shaded areas show high volatilities and the red columns are the smoothed regime probabilites based on MS-DR model

\section{EMPIRICAL RESULTS}

We tested two channels of contagion following Baur (2012) and Kenourgios and Dimitriou (2015). The channels in question can be explained as follows:

1. Contagion of regional stock market indicates increase in dynamic conditional correlation between regional stock market and world aggragate stock market index (MSCI) during the periods of crisis and COVID-19 pandemia across calm period. This channel presents financial contagion.

2. Contagion of regional real economy sector indicates increase in dynamic conditional correlation between regional non-financial sector stock index and MSCI index during the periods of crisis and COVID-19 pandemia across calm period. This channel presents the global financial contagion of real economy sector. 
To assess to these contagion channel, we first estimated dynamic conditional correlations from $\operatorname{ARMA}(2,2)$-FIGARCH(1,1)-DCC model for all stock market indices. After estimating dynamic conditional correlations, we generated two dummy variables defining crisis periods and COVID-19 pandemia period. Then, we set a model including the so-called dummy variables, which allows us to compared contagion effect in terms of crisis and COVID-19 pandemia. The model exhibiting dynamic conditional correlation behavior is as follows:

$$
p_{i j, t}=\alpha_{0}+\sum_{i=1}^{p} \beta_{p} p_{i j, t-p}+\delta_{1} \text { crisis }+\delta_{2} \text { covid }+\varepsilon_{i j, t}
$$

$\alpha_{0}$ and $p_{i j, t}$ present respectively constant term and dynamic conditional correlation. $\delta_{1}$ and $\delta_{2}$ are dummy variables regarding to respectively crisis period and COVID-19 pandemia period. Optimal lag lenght is identified by considering Akaike and Schwarz information criteria in the dynamic conditional correlation equation. Positive and significantly estimated dummy coefficients imply structural changes in mean of dynamic conditional correlations resulted from external shocks such as crisis and COVID-19 pandemia, which means the presence of contagion.

Table 2 exhibits the results from the ARMA(2,2)-FIGARCH(1,d,1)-DCC model with Student-t distributed errors for aggragate regional stock markets and world aggragate stock market index (MSCI). Table 3 exhibits the results from the ARMA(2,2)-GARCH(1,1)-DCC model with Student-t distributed errors for regional non-financial sector stock markets and world aggragate stock market index (MSCI). Dynamic conditional correlations between MSCI index and both regional stock market indices and regional non-financial sector indices are seen to be positive. Figure 3 indicates different dynamic conditional correlation structures between aggragate regional stock market indices and MSCI index for six countries while presenting different dynamic conditional correlation structures between regional non-financial sector indices and MSCI index in Figure 4.

Table 2. The Estimation results based on dynamic conditional correlations between regional stock indices and MSCI index

\begin{tabular}{|c|c|c|c|c|c|c|}
\hline & Turkey & China & Brazil & France & Italy & UK \\
\hline$\rho_{21}$ & $\begin{array}{l}0.3907^{* *} \\
(0.0112)\end{array}$ & $\begin{array}{l}0.1762^{2 k+k} \\
(0.0000)\end{array}$ & $\begin{array}{l}0.4434^{\star * *} \\
(0.0000)\end{array}$ & $\begin{array}{l}0.6413^{\text {knt* }} \\
(0.0000)\end{array}$ & $\begin{array}{l}0.5929^{\text {*kt }} \\
(0.0000)\end{array}$ & $\begin{array}{l}0.5948^{\text {*ton }} \\
(0.0000)\end{array}$ \\
\hline A & $\begin{array}{l}0.0064^{* *} \\
(0.0432)\end{array}$ & $\begin{array}{l}0.0106 \\
(0.2968) \\
\end{array}$ & $\begin{array}{l}0.0494^{\text {tat }} \\
(0.0004)\end{array}$ & $\begin{array}{l}0.0238^{\text {tat }} \\
(0.0092)\end{array}$ & $\begin{array}{l}0.0212^{* *} \\
(0.0191)\end{array}$ & $\begin{array}{l}0.0270^{*} \\
(0.0874)\end{array}$ \\
\hline B & $\begin{array}{l}0.9935^{\text {knt }} \\
(0.0000)\end{array}$ & $\begin{array}{l}0.9331^{\text {tat }} \\
(0.0000)\end{array}$ & $\begin{array}{l}0.8258^{\text {tat }} \\
(0.0000)\end{array}$ & $\begin{array}{l}0.9176^{\text {the }} \\
(0.0000)\end{array}$ & $\begin{array}{l}0.9353^{\text {that }} \\
(0.0000)\end{array}$ & $\begin{array}{l}0.8521^{*+\alpha} \\
(0.0000)\end{array}$ \\
\hline$\overline{\mathrm{Df}}$ & $\begin{array}{l}5.9999^{\text {tat }} \\
(0.0000)\end{array}$ & $\begin{array}{l}5.4613^{\text {tat }} \\
(0.0000)\end{array}$ & $\begin{array}{l}5.4852^{\text {tkx }} \\
(0.0000)\end{array}$ & $\begin{array}{l}5.2465^{\text {knt }} \\
(0.0000)\end{array}$ & $\begin{array}{l}5.1856^{\text {the }} \\
(0.0000)\end{array}$ & $\begin{array}{l}5.4440^{* *+x} \\
(0.0000)\end{array}$ \\
\hline Hosking(20) & 91.0782 & 98.618 & 92.1762 & 62.1059 & $27.7909^{*}$ & 23.6002 \\
\hline Hosking(50) & 196.93 & 207.116 & 146.453 & 155.232 & 32.5714 & 78.3764 \\
\hline Li-Mcleod(20) & 91.1261 & 98.6672 & 91.9597 & 62.1724 & $27.7684^{*}$ & 23.6869 \\
\hline Li-Mcleod(50) & 197.178 & 207.515 & 147.945 & 155.755 & 32.638 & 78.3074 \\
\hline
\end{tabular}

Notes: $\rho_{21}, \alpha, \beta$, df denote dynamic conditional correlations, the value or vector of autoregressive coefficients, the value or vector of variance coefficients, and degrees of freedom respectively. The esmiatations are obtained from ARMA(2,2)-FIGARCH(1,d,1)-DCC model. The lag order are determined by Akaike and Schwarz information criteria. The signs of ${ }^{* *},{ }^{* *},{ }^{*}$ denote the significance level at $1 \%$, $5 \%, 10 \%$ respectively. The values in ( ) are p-values. Hosking (1980) and Li-McLeod (1983) are the autocorrelation tests until lag 20 and lag 50 . 
Table 3. The Estimation results based on dynamic conditional correlations between regional non-financial sector indices and MSCI index

\begin{tabular}{|c|c|c|c|c|c|c|c|c|c|c|c|c|}
\hline & \multicolumn{6}{|c|}{ Turkey } & \multicolumn{6}{|c|}{ China } \\
\hline & $\begin{array}{l}\text { Industr } \\
\text { y }\end{array}$ & $\begin{array}{l}\text { Metaria } \\
1\end{array}$ & $\begin{array}{l}\text { Financial } \\
\mathrm{s}\end{array}$ & Energy & $\begin{array}{l}\text { Technolog } \\
\mathrm{y}\end{array}$ & $\begin{array}{l}\text { Telecomunication } \\
\mathrm{s}\end{array}$ & $\begin{array}{l}\text { Industr } \\
\mathrm{y}\end{array}$ & $\begin{array}{l}\text { Metaria } \\
1\end{array}$ & $\begin{array}{l}\text { Financial } \\
\mathrm{s}\end{array}$ & Energy & $\begin{array}{l}\text { Technolog } \\
\mathrm{y}\end{array}$ & $\begin{array}{l}\text { Telecomunication } \\
\mathrm{s}\end{array}$ \\
\hline$\overline{\rho_{21}}$ & $\begin{array}{l}0.2782 \cdots \\
(0.0000)\end{array}$ & $\begin{array}{l}0.2318^{\cdots \prime} \\
(0.0000)\end{array}$ & $\begin{array}{l}0.2705^{\prime \prime} \\
(0.0051)\end{array}$ & $\begin{array}{l}0.2348^{\prime \prime} \\
(0.0000\end{array}$ & $\begin{array}{l}0.1925^{* \prime \prime} \\
(0.0000)\end{array}$ & $\begin{array}{l}0.2548^{-\prime} \\
(0.0000)\end{array}$ & $\begin{array}{l}0.20111^{\prime \prime} \\
(0.0000)\end{array}$ & $\begin{array}{l}0.19699^{-1} \\
(0.0000\end{array}$ & $\begin{array}{l}0.2406^{\prime \prime \prime} \\
(0.0000)\end{array}$ & $\begin{array}{l}0.1749^{-\prime} \\
(0.0000\end{array}$ & $\begin{array}{l}0.13177^{\prime \prime} \\
(0.0000)\end{array}$ & $\begin{array}{l}0.1329 \cdots \\
(0.0000)\end{array}$ \\
\hline $\bar{a}$ & $\begin{array}{l}0.0158 \\
(0.3441)\end{array}$ & $\begin{array}{l}0.0002 \\
(0.5999)\end{array}$ & $\begin{array}{l}0.0416 \\
(0.1472)\end{array}$ & $\begin{array}{l}0.0478^{*} \\
(0.0902\end{array}$ & $\begin{array}{l}0.0087 \\
(0.1868)\end{array}$ & $\begin{array}{l}0.0079 \\
(0.3686)\end{array}$ & $\begin{array}{l}0.0026 \\
(0.3392)\end{array}$ & $\begin{array}{l}0.0020 \\
(0.4308)\end{array}$ & $\begin{array}{l}0.0233^{\circ} \\
(0.0863)\end{array}$ & $\begin{array}{l}0.0057 \\
(0.5490\end{array}$ & $\begin{array}{l}0.0079 \\
(0.4555)\end{array}$ & $\begin{array}{l}0.0268 \\
(0.3677)\end{array}$ \\
\hline $\bar{\beta}$ & $\begin{array}{l}0.88588^{\cdots} \\
(0.0000)\end{array}$ & $\begin{array}{l}0.8998^{* *} \\
(0.0000)\end{array}$ & $\begin{array}{l}0.5931^{\prime \cdots} \\
(0.0000)\end{array}$ & $\begin{array}{l}0.5578^{\prime *} \\
(0.0463 \\
)^{2}\end{array}$ & $\begin{array}{l}0.9737 \cdots \\
(0.0000)\end{array}$ & $\begin{array}{l}0.9486^{-m} \\
(0.0000)\end{array}$ & $\begin{array}{l}0.99177^{* \prime} \\
(0.0000)\end{array}$ & $\begin{array}{l}0.99255^{\prime \prime} \\
(0.0000)\end{array}$ & $\begin{array}{l}0.9079 \cdots \\
(0.0000)\end{array}$ & $\begin{array}{l}0.8184^{\prime \prime} \\
0.0000\end{array}$ & $\begin{array}{l}0.8528^{\prime \prime} \\
(0.0170)\end{array}$ & $\begin{array}{l}0.0872 \\
(0.7318)\end{array}$ \\
\hline df & $\begin{array}{l}4.5500^{\circ-} \\
(0.0000)\end{array}$ & $\begin{array}{l}4.3274^{\prime \prime} \\
(0.0000)\end{array}$ & $\begin{array}{l}4.2539 \cdots \\
(0.0000)\end{array}$ & $\begin{array}{l}5.1543^{\prime \prime} \\
(0.0000 \\
)^{2}\end{array}$ & $\begin{array}{l}5.0321^{\cdots} \\
(0.0000)\end{array}$ & $\begin{array}{l}5.6112^{m} \\
(0.0000)\end{array}$ & $\begin{array}{l}4.7761^{\prime \prime \prime} \\
(0.0000)\end{array}$ & $\begin{array}{l}5.8786^{\prime \prime \prime} \\
(0.0000)\end{array}$ & $\begin{array}{l}4.9229 \cdots \\
(0.0000)\end{array}$ & $\begin{array}{l}5.1105^{\prime \prime} \\
(0.0000\end{array}$ & $\begin{array}{l}6.3952 \cdots \\
(0.0000)\end{array}$ & $\begin{array}{l}6.1897^{m} \\
(0.0000)\end{array}$ \\
\hline Hosking(20) & 104.261 & 81.8329 & 94.7418 & 50.3809 & 86.1383 & 47.8161 & 60.7455 & 88.5430 & 75.8860 & 48.0383 & 74.2842 & 69.8245 \\
\hline Hosking(50) & 223.436 & 153.122 & 210.869 & 223.437 & 204.006 & 224.467 & 212.721 & 206.798 & 210.677 & 236.808 & 222.160 & 185.976 \\
\hline $\begin{array}{l}\text { Li- } \\
\text { Mcleod(20) }\end{array}$ & 104.136 & 81.8357 & 94.7536 & 50.3701 & 86.0991 & 47.8118 & 60.8307 & 88.7630 & 75.9317 & 48.2092 & 74.4086 & 70.0141 \\
\hline \multirow[t]{3}{*}{$\begin{array}{l}\text { Li- } \\
\text { Mcleod(50) }\end{array}$} & 223.378 & 154.376 & 210.976 & 223.418 & 204.040 & 224.630 & 213.057 & 207.263 & 210.495 & 235.27 & 221.634 & 186.384 \\
\hline & \multicolumn{6}{|c|}{ Brazil } & \multicolumn{6}{|c|}{ France } \\
\hline & $\begin{array}{l}\text { Industr } \\
\text { y }\end{array}$ & $\begin{array}{l}\text { Metaria } \\
1\end{array}$ & $\begin{array}{l}\text { Financial } \\
\mathrm{s}\end{array}$ & Energy & $\begin{array}{l}\text { Technolog } \\
\text { y }\end{array}$ & $\begin{array}{l}\text { Telecomunication } \\
\mathrm{s}\end{array}$ & $\begin{array}{l}\text { Industr } \\
\text { y }\end{array}$ & $\begin{array}{l}\text { Metaria } \\
1\end{array}$ & $\begin{array}{l}\text { Financial } \\
\mathrm{s}\end{array}$ & Energy & $\begin{array}{l}\text { Technolog } \\
\text { y }\end{array}$ & $\begin{array}{l}\text { Telecomunication } \\
\mathrm{s}\end{array}$ \\
\hline$\rho_{21}$ & $\begin{array}{l}0.4180^{-\cdots} \\
(0.0000)\end{array}$ & $\begin{array}{l}0.3875^{-*} \\
(0.0000)\end{array}$ & $\begin{array}{l}0.3855^{-\cdots} \\
(0.0000)\end{array}$ & $\begin{array}{l}0.3253^{\prime \prime} \\
(0.0000 \\
j^{2}\end{array}$ & - & - & $\begin{array}{l}0.5997 \cdots \\
(0.0000)\end{array}$ & $\begin{array}{l}0.6307^{\prime \prime} \\
(0.0000)\end{array}$ & $\begin{array}{l}0.5024 \cdots \\
(0.0000)\end{array}$ & $\begin{array}{l}0.5343^{\prime \prime} \\
(0.0000 \\
j^{2}\end{array}$ & - & - \\
\hline$a$ & $\begin{array}{l}0.0820^{-\cdots} \\
(0.0000)\end{array}$ & $\begin{array}{l}0.0470^{-\cdots} \\
(0.0042)\end{array}$ & $\begin{array}{l}0.0426^{\prime \prime \prime} \\
(0.0031)\end{array}$ & $\begin{array}{l}0.0510^{*} \\
(0.0232 \\
)^{2}\end{array}$ & - & - & $\begin{array}{l}0.0602 \cdots \\
(0.0001)\end{array}$ & $\begin{array}{l}0.04077^{\prime \prime} \\
(0.0041)\end{array}$ & $\begin{array}{l}0.0326^{\circ} \\
(0.0688)\end{array}$ & $\begin{array}{l}0.0726^{*} \\
)^{(0.0001} \\
\end{array}$ & - & - \\
\hline $\bar{\beta}$ & $\begin{array}{l}0.7396^{\prime \prime \prime} \\
(0.0000)\end{array}$ & $\begin{array}{l}0.8236^{\prime \prime} \\
(0.0000)\end{array}$ & $\begin{array}{l}0.8614^{-*} \\
(0.0000)\end{array}$ & $\begin{array}{l}0.7855^{*} \\
(0.0000 \\
)^{2}\end{array}$ & - & - & $\begin{array}{l}0.8487^{\cdots} \\
(0.0000)\end{array}$ & $\begin{array}{l}0.8994^{* \prime \prime} \\
(0.0000)\end{array}$ & $\begin{array}{l}0.8373^{* \prime} \\
(0.0000)\end{array}$ & $\begin{array}{l}0.8116^{\prime \prime} \\
(0.0000 \\
)^{2}\end{array}$ & - & - \\
\hline df & $\begin{array}{l}5.2297 \cdots \\
(0.0000)\end{array}$ & $\begin{array}{l}6.0729 \cdots \\
(0.0000)\end{array}$ & $\begin{array}{l}5.2520^{m} \\
(0.0000)\end{array}$ & $\begin{array}{l}4.8569^{\prime \prime} \\
(0.0000 \\
)^{2}\end{array}$ & - & - & $\begin{array}{l}4.7510^{-*} \\
(0.0000)\end{array}$ & $\begin{array}{l}5.4161^{\prime \prime} \\
(0.0000)\end{array}$ & $\begin{array}{l}4.3466^{\prime \prime \prime} \\
(0.0000)\end{array}$ & $\begin{array}{l}5.8895^{\prime \prime} \\
(0.0000 \\
)^{2}\end{array}$ & - & - \\
\hline Hosking(20) & 87.8079 & 91.0060 & 44.1315 & 83.8543 & - & - & 21.1513 & 27.3664 & 32.5472 & 25.1145 & - & - \\
\hline Hosking(50) & 163.775 & 238.573 & 168.505 & 228.753 & - & - & 204.912 & 198.988 & 209.244 & 219.997 & - & - \\
\hline $\begin{array}{l}\text { Li- } \\
\text { Mcleod(20) }\end{array}$ & 87.7303 & 91.0158 & 44.1413 & 83.7170 & - & - & 21.2118 & 27.4207 & 32.5791 & 25.1886 & - & - \\
\hline $\begin{array}{l}\text { Li- } \\
\text { Mcleod(50) }\end{array}$ & 165.041 & 237.878 & 169.788 & 227.370 & - & - & 205.420 & 197.988 & 209.723 & 219.848 & - & - \\
\hline
\end{tabular}

Notes: $\rho_{21}, \alpha, \beta$, df denote dynamic conditional correlations, the value or vector of autoregressive coefficients, the value or vector of variance coefficients, and degrees of freedom respectively. The esmiatations are obtained from ARMA (2,2)-FIGARCH(1,d,1)-DCC model. The lag order are determined by Akaike and Schwarz information criteria. The signs of ${ }^{* * *}, * *, *$ denote the significance level at $1 \%$, $5 \%, 10 \%$ respectively. The values in ( ) are p-values. Hosking (1980) and Li-McLeod (1983) are the autocorrelation tests until lag 20 and lag 50 . The values of technology and telecommunication sectors for Brazil and France couldn't be reached 
Table 3. The Estimation results based on dynamic conditional correlations between regional non-financial sector indices and MSCI index

\begin{tabular}{|c|c|c|c|c|c|c|c|c|c|c|c|c|}
\hline & \multicolumn{6}{|c|}{ Italy } & \multicolumn{6}{|c|}{ United Kingdom } \\
\hline & $\begin{array}{l}\text { Industr } \\
\mathrm{y}\end{array}$ & $\begin{array}{l}\text { Metaria } \\
1\end{array}$ & $\begin{array}{l}\text { Financial } \\
\mathrm{s}\end{array}$ & Energy & $\begin{array}{l}\text { Technolog } \\
\text { y }\end{array}$ & $\begin{array}{l}\text { Telecomunication } \\
\mathrm{s}\end{array}$ & $\begin{array}{l}\text { Industr } \\
\mathrm{y}\end{array}$ & $\begin{array}{l}\text { Metaria } \\
1\end{array}$ & $\begin{array}{l}\text { Financial } \\
\mathrm{s}\end{array}$ & Energy & $\begin{array}{l}\text { Technolog } \\
\text { y }\end{array}$ & $\begin{array}{l}\text { Telecomunication } \\
\mathrm{s}\end{array}$ \\
\hline$\overline{\rho_{21}}$ & $\begin{array}{l}0.5594^{\prime \prime \prime} \\
(0.0000)\end{array}$ & $\begin{array}{l}0.4381^{\prime \prime} \\
(0.0000)\end{array}$ & $\begin{array}{l}0.4889 \cdots \\
(0.0000)\end{array}$ & $\begin{array}{l}0.5432 " * \\
(0.0000 \\
)^{2}\end{array}$ & $\begin{array}{l}0.5205^{* \cdots} \\
(0.0000)\end{array}$ & $\begin{array}{l}0.36533^{-\cdots} \\
(0.0000)\end{array}$ & $\begin{array}{l}0.5623^{3 \prime} \\
(0.0000)\end{array}$ & $\begin{array}{l}0.5182 \\
(0.0000)\end{array}$ & $\begin{array}{l}0.5278^{* \cdots} \\
(0.0000)\end{array}$ & $\begin{array}{l}0.4190^{-2} \\
(0.0000 \\
j^{4}\end{array}$ & $\begin{array}{l}0.3844^{* \prime} \\
(0.0000)\end{array}$ & $\begin{array}{l}0.3665 " ' \\
(0.0000)\end{array}$ \\
\hline $\bar{a}$ & $\begin{array}{l}0.0323^{m} \\
(0.0000)\end{array}$ & $\begin{array}{l}0.0199 \\
(0.1297)\end{array}$ & $\begin{array}{l}0.0311^{\prime \prime} \\
(0.0080)\end{array}$ & $\begin{array}{l}0.0625^{\prime \prime} \\
(0.0003 \\
i^{2}\end{array}$ & $\begin{array}{l}0.0170^{\circ-1} \\
(0.0081)\end{array}$ & $\begin{array}{l}0.0104^{\prime \prime} \\
(0.0405)\end{array}$ & $\begin{array}{l}0.04955^{\prime \prime} \\
(0.0088)\end{array}$ & $\begin{array}{l}0.0305 \\
(0.2624)\end{array}$ & $\begin{array}{l}0.0613^{* \prime} \\
(0.0146)\end{array}$ & $\begin{array}{l}0.0094 \\
(0.2796 \\
)^{2}\end{array}$ & $\begin{array}{l}0.0461^{\circ} \\
(0.0825)\end{array}$ & $\begin{array}{l}0.0450^{-1} \\
(0.0128)\end{array}$ \\
\hline $\bar{\beta}$ & $\begin{array}{l}0.9387 \cdots \\
(0.0000)\end{array}$ & $\begin{array}{l}0.9330^{--} \\
(0.0000)\end{array}$ & $\begin{array}{l}0.8896^{\prime \prime \prime} \\
(0.0000)\end{array}$ & $\begin{array}{l}0.8406^{* \prime} \\
(0.0000 \\
j^{2}\end{array}$ & $\begin{array}{l}0.9744^{\prime *} \\
(0.0000)\end{array}$ & $\begin{array}{l}0.9788^{-\cdots} \\
(0.0000)\end{array}$ & $\begin{array}{l}0.84955^{\cdots *} \\
(0.0000)\end{array}$ & $\begin{array}{l}0.9212 \cdots \\
(0.0000)\end{array}$ & $\begin{array}{l}0.8009 " \cdots \\
(0.0000)\end{array}$ & $\begin{array}{l}0.9819^{\prime \prime} \\
(0.0000 \\
j^{2}\end{array}$ & $\begin{array}{l}0.7665^{* *} \\
(0.0014)\end{array}$ & $\begin{array}{l}0.8427 \cdots \\
(0.0000)\end{array}$ \\
\hline df & $\begin{array}{l}5.3468 \\
(0.0000)\end{array}$ & $\begin{array}{l}4.5546^{-\prime \prime} \\
(0.0000)\end{array}$ & $\begin{array}{l}4.9985^{\prime \prime \prime} \\
(0.0000)\end{array}$ & $\begin{array}{l}5.8966^{\prime \prime} \\
(0.0000 \\
\end{array}$ & $\begin{array}{l}5.2028 \cdots \\
(0.0000)\end{array}$ & $\begin{array}{l}5.4921^{\prime \prime} \\
(0.0000)\end{array}$ & $\begin{array}{l}5.5235^{\cdots *} \\
(0.0000)\end{array}$ & $\begin{array}{l}6.3345^{\prime \prime \prime} \\
(0.0000)\end{array}$ & $\begin{array}{l}5.4603^{3} \cdots \\
(0.0000)\end{array}$ & 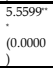 & $\begin{array}{l}3.3688^{-*} \\
(0.0000)\end{array}$ & $\begin{array}{l}4.92300^{-\prime \prime} \\
(0.0000)\end{array}$ \\
\hline Hosking(20) & 48.8715 & 51.4597 & 23.9224 & 42.1369 & 46.6913 & 42.2905 & 85.1667 & 64.0938 & 89.7217 & 72.7980 & 109.754 & 76.6893 \\
\hline Hosking(50) & 93.2357 & 82.0212 & 70.7628 & 86.6837 & 91.4810 & 72.0361 & 158.963 & 130.792 & 168.918 & 212.747 & 250.044 & 192.988 \\
\hline $\begin{array}{l}\text { Li- } \\
\text { Mcleod(20) }\end{array}$ & 48.9339 & 51.4748 & 24.0030 & 42.1712 & 46.6954 & 42.3005 & 85.0240 & 64.0988 & 89.5498 & 72.9708 & 109.476 & 76.7999 \\
\hline $\begin{array}{l}\text { Li- } \\
\text { Mcleod(50) }\end{array}$ & 93.2174 & 82.1170 & 70.7501 & 86.6551 & 91.4018 & 72.1480 & 160.016 & 131.994 & 169.922 & 212.410 & 249.350 & 193.182 \\
\hline
\end{tabular}

Notes: $\rho_{21}, \alpha, \beta$, df denote dynamic conditional correlations, the value or vector of autoregressive coefficients, the value or vector of variance coefficients, and degrees of freedom respectively. The esmiatations are obtained from ARMA (2,2)-FIGARCH(1,d,1)-DCC model. The lag order are determined by Akaike and Schwarz information criteria. The signs of ${ }^{* * *}, * *, *$ denote the significance level at $1 \%$, $5 \%, 10 \%$ respectively. The values in ( ) are p-values. Hosking (1980) and Li-McLeod (1983) are the autocorrelation tests until lag 20 and lag 50. 


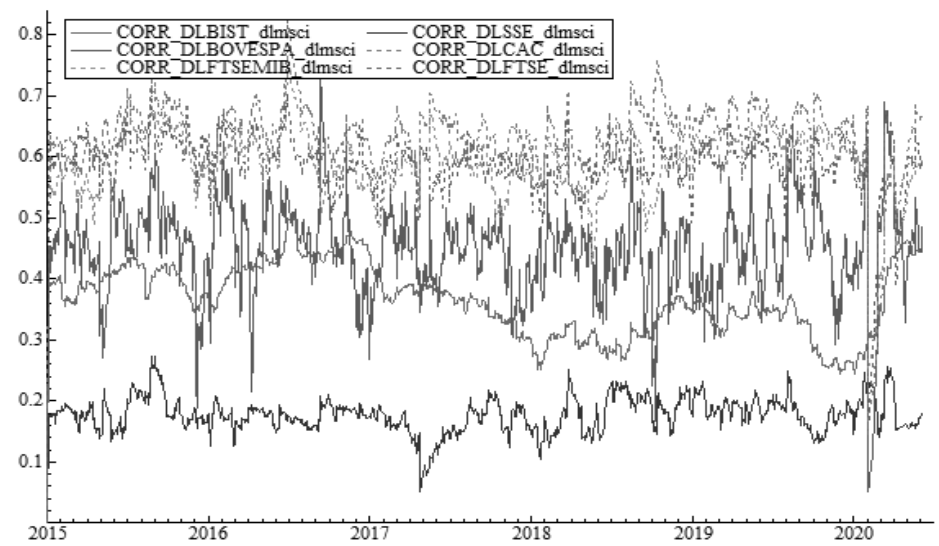

Figure 3. Dynamic Conditional Correlation. This figure presents the assessment of dynamic conditional correlations between regional stock market indices and MSCI index for each countries over the period of 03.01.2015-03.06.2020

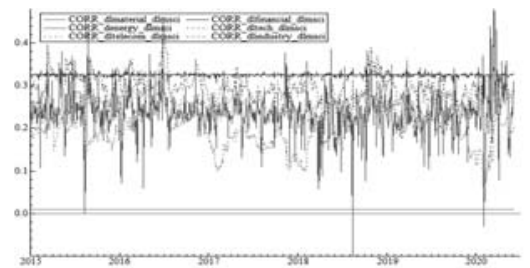

China

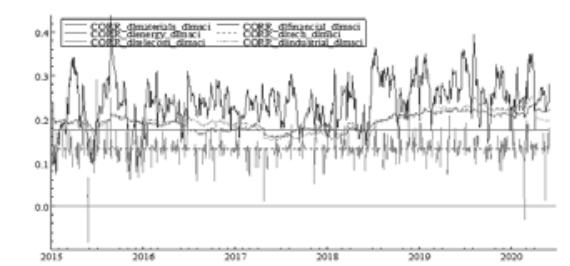

Turkey

Brazil

France

Italy

United Kingdom

Figure 4. Dynamic Conditional Correlation. This figure presents the assessment of dynamic conditional correlations between regional non-financial sector indices and MSCI index for each countries over the period of 03.01.2015-03.06.2020

The model estimation results created to investigate the presence of financial contagion (the aggragate regional stock market contagion) for each countries are shown in Table 4 . The
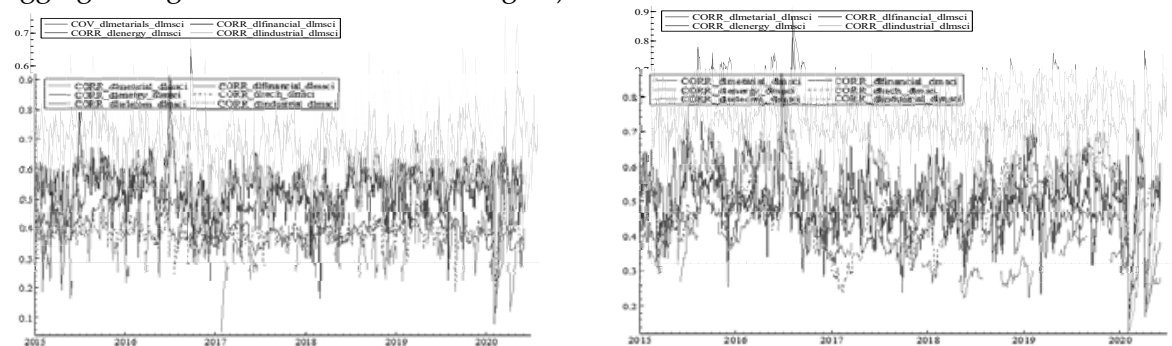
presence of financial contagion has been taken into account both in terms of crisis period and COVID-19 period. Positive and significantly estimated dummy coefficients imply that the dynamic conditional correlations during the periods of crisis and COVID-19 are significantly differ from calm period, which proves the presence of financial contagion.

Table 4. Estimation results for regional aggregate stock market contagion

\begin{tabular}{|c|c|c|c|c|c|c|}
\hline & Turkey & China & Brazil & France & Italy & $\begin{array}{l}\text { United } \\
\text { Kingdom }\end{array}$ \\
\hline$\alpha_{0}$ & $\begin{array}{l}4.89 \mathrm{E}-05^{\star *} \\
(0.0206)\end{array}$ & $\begin{array}{l}\text { 3.51E-05 } \\
(0.1158)\end{array}$ & $\begin{array}{l}0.0006^{\text {k*k }} \\
(00183)\end{array}$ & $\begin{array}{l}0.0006^{\text {}} \\
(0.0001)\end{array}$ & $\begin{array}{l}0.0006^{\text {k*k }} \\
(0.0005)\end{array}$ & $\begin{array}{l}0.0003^{* *} \\
(0.0263)\end{array}$ \\
\hline$\beta_{1}$ & $\begin{array}{l}0.9565^{\star \star * k} \\
(0.0000)\end{array}$ & $\begin{array}{l}0.9467^{\star \star * \star} \\
(0.0000)\end{array}$ & $\begin{array}{l}0.7146^{* * *} \\
(0.0000)\end{array}$ & $\begin{array}{l}0.7117^{\star * \star} \\
(0.0000)\end{array}$ & $\begin{array}{l}0.7097^{\star * *} \\
(0.0000)\end{array}$ & $\begin{array}{l}0.7637^{* * *} \\
(0.0000)\end{array}$ \\
\hline$\delta_{1}$ & $\begin{array}{l}0.0002^{* *} \\
(0.0113)\end{array}$ & $\begin{array}{l}0.0003^{\text {**k }} \\
(0.0000)\end{array}$ & $\begin{array}{l}0.0005 \\
(0.6726)\end{array}$ & $\begin{array}{l}0.0019^{* * *} \\
(0.0059)\end{array}$ & $\begin{array}{l}0.0018^{* k} \\
(0.0311)\end{array}$ & $\begin{array}{l}0.0010 \\
(0.1571)\end{array}$ \\
\hline$\delta_{2}$ & $\begin{array}{l}0.0002^{* * *} \\
(0.0023)\end{array}$ & $\begin{array}{l}0.0002^{* \star * k} \\
(0.0011)\end{array}$ & $\begin{array}{l}0.0043^{* * *} \\
(0.0000)\end{array}$ & $\begin{array}{l}0.0028^{* * k} \\
(0.0000)\end{array}$ & $\begin{array}{l}0.0024^{* k *} \\
(0.0020)\end{array}$ & $\begin{array}{l}0.0016^{* *} \\
(0.0266)\end{array}$ \\
\hline
\end{tabular}

Notes: The estimations are based on Equation 6. The lag order are determined by Akaike and Schwarz information criteria. The values in ( ) are p-values. The signs of $* * *, * *, *$ denote the significance level at $1 \%, 5 \%, 10 \%$ respectively. $\delta_{1}$ and $\delta_{2}$ are the dummy variable coefficients for crisis period and COVDI-19 pandemia period. Positive and significantly estimated dummy variable coefficients reveal the presence of financial contagion

The estimation results in Table 4 present that the evidence of financial contagion is found for Turkey, China, France and Italy, while no evidence for Brazil and United Kingdom in crisis period. As considering COVID-19 period, it is seen to be provided for financial contagion for all countries. The most affected region by COVID-19 is Brazil. The reason is that Brazil is second country with the highest COVID-19 cases number. However, the least affected country is United Kingdom.

The model estimation results created to examine the presence of financial contagion of real economy sector (the global financial contagion of real economy sectors) are shown in Table 5. From the results, it is seen that non-financial firms are directly impacted by the global financial system and therefore, COVID-19 pandemia has a direct affect on the so-called firms. However, energy and telecommuniaction sectors in China are not influenced by COVID-19 pandemia. The sectors most affected by COVID-19 pandemia are financial in China, France, Italy, United Kingdom; but, energy in Brazil and Turkey. 
Table 5. Estimation results for global financial contagion of regional real economy sectors

\begin{tabular}{|c|c|c|c|c|c|c|c|c|c|c|c|c|}
\hline & \multicolumn{6}{|c|}{ Turkey } & \multicolumn{6}{|c|}{ China } \\
\hline & Industry & Metarial & $\begin{array}{l}\text { Financia } \\
\text { ls }\end{array}$ & Energy & $\begin{array}{l}\text { Technol } \\
\text { ogy }\end{array}$ & $\begin{array}{l}\text { Telecomunica } \\
\text { tion }\end{array}$ & Industry & Metarial & $\begin{array}{l}\text { Financia } \\
\text { ls }\end{array}$ & Energy & $\begin{array}{l}\text { Technolo } \\
\text { gy }\end{array}$ & $\begin{array}{l}\text { Telecomunica } \\
\text { tion }\end{array}$ \\
\hline$\alpha_{0}$ & $\begin{array}{l}1.60 \mathrm{E}-05 \\
(0.314)\end{array}$ & $\begin{array}{l}0.0002^{2+3} \\
(0.0001)\end{array}$ & $\begin{array}{l}3.97 \mathrm{E}-05^{*} \\
(0.0573)\end{array}$ & $\begin{array}{l}0.0001^{+t+2} \\
(0.0000)\end{array}$ & $\begin{array}{l}2.47 \mathrm{E}- \\
05^{\circ} \\
(0.0597)\end{array}$ & $\begin{array}{l}3.14 \mathrm{E}-05 \\
(0.0002)\end{array}$ & $\begin{array}{l}1.92 \mathrm{E}-05^{+*} \\
(0.0301)\end{array}$ & $\begin{array}{l}1.67 \mathrm{E}-05^{\text {t+t }} \\
(0.0076)\end{array}$ & $\begin{array}{l}2.37 \mathrm{E}- \\
05^{-*} \\
(0.0003)\end{array}$ & $\begin{array}{l}7.35 \mathrm{E}-05^{+3 t} \\
(0.0082)\end{array}$ & $\begin{array}{l}1.40 \mathrm{E}- \\
05^{-{ }^{*}} \\
(0.0184)\end{array}$ & $\begin{array}{l}4.76 \mathrm{E}-05^{\text {th+t }} \\
(0.0000)\end{array}$ \\
\hline$\overline{\beta_{1}}$ & $\begin{array}{l}0.9423^{\text {*n+* }} \\
(0.0000)\end{array}$ & $\begin{array}{l}0.7524^{4+4} \\
(0.0001)\end{array}$ & $\begin{array}{l}0.9267^{7+1+} \\
(0.0000)\end{array}$ & $\begin{array}{l}0.6788^{+t+1} \\
(0.0000)\end{array}$ & $\begin{array}{l}0.9198^{+t+4} \\
(0.0000)\end{array}$ & $\begin{array}{l}0.9199^{+2+t} \\
(0.0000)\end{array}$ & $\begin{array}{l}0.9292^{2+3+} \\
(0.0000)\end{array}$ & $\begin{array}{l}0.9349^{\text {tot }} \\
(0.0000)\end{array}$ & $\begin{array}{l}0.9140^{+3+1} \\
(0.0000)\end{array}$ & $\begin{array}{l}0.8031^{\text {toth }} \\
(0.0000)\end{array}$ & $\begin{array}{l}0.9353^{+1+} \\
(0.0000)\end{array}$ & $\begin{array}{l}0.8276^{6+1} \\
(0.0000)\end{array}$ \\
\hline$\delta_{1}$ & $\begin{array}{l}0.0002^{2+*+} \\
(0.0000)\end{array}$ & $\begin{array}{l}0.0011^{+4+1} \\
(0.0001)\end{array}$ & $\begin{array}{l}0.0003^{\text {wat }} \\
(0.0000)\end{array}$ & $\begin{array}{l}0.0004^{+*+1} \\
(0.0000)\end{array}$ & $\begin{array}{l}0.0002^{2+3} \\
(0.0000)\end{array}$ & $\begin{array}{l}0.0002^{2+*} \\
(0.0000)\end{array}$ & $\begin{array}{l}0.0002^{2+3} \\
(0.0000)\end{array}$ & $\begin{array}{l}0.0002^{2+4+} \\
(0.0000)\end{array}$ & $\begin{array}{l}0.0003^{+3+1} \\
(0.0000)\end{array}$ & $\begin{array}{l}0.0002^{\text {tat }} \\
(0.0036)\end{array}$ & $\begin{array}{l}0.0002^{+4+} \\
(0.0000)\end{array}$ & $\begin{array}{l}0.0003^{+m+1} \\
(0.0000)\end{array}$ \\
\hline \multirow[t]{3}{*}{$\overline{\delta_{2}}$} & $\begin{array}{l}0.0001^{*} \\
(0.0894)\end{array}$ & $\begin{array}{l}0.0016^{6+4} \\
(0.0000)\end{array}$ & $\begin{array}{l}0.0001^{*} \\
(0.0504)\end{array}$ & $\begin{array}{l}0.0002^{+*} \\
(0.0160)\end{array}$ & $\begin{array}{l}0.0001^{+3+} \\
(0.0015)\end{array}$ & $\begin{array}{l}0.0001^{+* *} \\
(0.0001)\end{array}$ & $\begin{array}{l}0.0001^{*} \\
(0.0844)\end{array}$ & $\begin{array}{l}6.66 \mathrm{E}-05^{+*} \\
(0.0448)\end{array}$ & $\begin{array}{l}0.0001^{+*} \\
(0.0275)\end{array}$ & $\begin{array}{l}0.0002 \\
(0.1697)\end{array}$ & $\begin{array}{l}7.21 \mathrm{E}- \\
05^{-*} \\
(0.0124)\end{array}$ & $\begin{array}{l}7.28 \mathrm{E}-05 \\
(0.1926)\end{array}$ \\
\hline & \multicolumn{6}{|c|}{ Brazil } & \multicolumn{6}{|c|}{ France } \\
\hline & Industry & Metarial & $\begin{array}{l}\text { Financia } \\
\text { ls }\end{array}$ & Energy & $\begin{array}{l}\text { Technol } \\
\text { ogy }\end{array}$ & $\begin{array}{l}\text { Telecomunica } \\
\text { tion }\end{array}$ & Industry & Metarial & $\begin{array}{l}\text { Financia } \\
\text { ls }\end{array}$ & Energy & $\begin{array}{l}\text { Technolo } \\
\text { gy }\end{array}$ & $\begin{array}{l}\text { Telecomunica } \\
\text { tion }\end{array}$ \\
\hline$\alpha_{0}$ & $\begin{array}{l}8.6405 \\
(0.2914)\end{array}$ & $\begin{array}{l}6.99 \mathrm{E}-05 \\
(0.1469)\end{array}$ & $\begin{array}{l}0.0001^{*+} \\
(0.0544)\end{array}$ & $\begin{array}{l}0.0002^{+*+1} \\
(0.0196)\end{array}$ & - & - & $\begin{array}{l}0.0001 \\
(0.1494)\end{array}$ & $\begin{array}{l}0.0001^{+*} \\
(0.0183)\end{array}$ & $\begin{array}{l}0.0005^{*} \\
(0.0744)\end{array}$ & $\begin{array}{l}0.0001 \\
(0.1904)\end{array}$ & - & - \\
\hline$\beta_{1}$ & $\begin{array}{l}0.8711^{\prime+*} \\
(0.0000)\end{array}$ & $\begin{array}{l}0.9112^{2+4} \\
(0.0000)\end{array}$ & $\begin{array}{l}0.8915^{+\ldots+*} \\
(0.0000)\end{array}$ & $\begin{array}{l}0.6504^{+4+} \\
(0.0000)\end{array}$ & - & - & $\begin{array}{l}0.8093^{+*+*} \\
(0.0000)\end{array}$ & $\begin{array}{l}0.8733^{\text {t** }} \\
(0.0000)\end{array}$ & $\begin{array}{l}0.4993^{+4+} \\
(0.0000)\end{array}$ & $\begin{array}{l}0.8808^{\text {toth }} \\
(0.0000)\end{array}$ & - & - \\
\hline$\overline{\delta_{1}}$ & $\begin{array}{l}0.0001 \\
(0.5911)\end{array}$ & $\begin{array}{l}0.0002 \\
(0.2208)\end{array}$ & $\begin{array}{l}0.0001 \\
(0.4090)\end{array}$ & $\begin{array}{l}00003 \\
(0.3868)\end{array}$ & - & - & $\begin{array}{l}0.0014^{*+} \\
(0.0116)\end{array}$ & $\begin{array}{l}0.0008^{\text {tw+ }} \\
(0.0009)\end{array}$ & $\begin{array}{l}0.0031^{* *} \\
(0.0378)\end{array}$ & $\begin{array}{l}0.0007^{* *} \\
(0.0578)\end{array}$ & - & - \\
\hline \multirow[t]{3}{*}{$\delta_{2}$} & $\begin{array}{l}0.0011^{*+*} \\
(0.0001)\end{array}$ & $\begin{array}{l}0.0007^{+4+4} \\
(0.0000)\end{array}$ & $\begin{array}{l}0.0008^{*+*} \\
(0.0000)\end{array}$ & $\begin{array}{l}0.0013^{+*+1} \\
(0.0001)\end{array}$ & - & - & $\begin{array}{l}0.0016^{\text {tat+ }} \\
(0.0008)\end{array}$ & $\begin{array}{l}0.0007^{\text {ton }} \\
(0.0007)\end{array}$ & $\begin{array}{l}0.0068^{+m+1} \\
(0.0000)\end{array}$ & $\begin{array}{l}0.0012^{2+3} \\
(0.0001)\end{array}$ & - & - \\
\hline & \multicolumn{6}{|c|}{ Italy } & \multicolumn{6}{|c|}{ United Kingdom } \\
\hline & Industry & Metarial & $\begin{array}{l}\text { Financia } \\
\text { ls }\end{array}$ & Energy & $\begin{array}{l}\text { Technol } \\
\text { ogy }\end{array}$ & $\begin{array}{l}\text { Telecomunica } \\
\text { tion }\end{array}$ & Industry & Metarial & $\begin{array}{l}\text { Financia } \\
\text { ls }\end{array}$ & Energy & $\begin{array}{l}\text { Technolo } \\
\text { gy }\end{array}$ & $\begin{array}{l}\text { Telecomunica } \\
\text { tion }\end{array}$ \\
\hline$\alpha_{0}$ & $\begin{array}{l}0.0002^{+*} \\
(0.0460)\end{array}$ & $\begin{array}{l}8.76 \mathrm{E}- \\
05^{* *} \\
(0.0300)\end{array}$ & $\begin{array}{l}0.0002^{* *} \\
(0.0407)\end{array}$ & $\begin{array}{l}6.89 \mathrm{E}- \\
05 \\
(0.1287)\end{array}$ & $\begin{array}{l}0.0001^{+4+1} \\
(0.0088)\end{array}$ & $\begin{array}{l}9.74 \mathrm{E}-05 \\
(0.2179)\end{array}$ & $\begin{array}{l}0.0001^{*} \\
(0.0632)\end{array}$ & $\begin{array}{l}9.00 \mathrm{E}-05^{*} \\
(0.0845)\end{array}$ & $\begin{array}{l}0.0002^{+*+1} \\
(0.0300)\end{array}$ & $\begin{array}{l}0.0001 \\
(0.2292)\end{array}$ & $\begin{array}{l}0.0002^{+*} \\
(0.0001)\end{array}$ & $\begin{array}{l}8.55 \mathrm{E}-05^{\circ+} \\
(0.0304)\end{array}$ \\
\hline$\beta_{1}$ & $\begin{array}{l}0.7035^{+*} \\
(0.0000)\end{array}$ & $\begin{array}{l}0.9174^{4+4} \\
(0.0000)\end{array}$ & $\begin{array}{l}0.6585^{5+1+} \\
(0.0000)\end{array}$ & $\begin{array}{l}0.9040^{+20+} \\
(0.0000)\end{array}$ & $\begin{array}{l}0.0171^{\text {tont }} \\
(0.0000)\end{array}$ & $\begin{array}{l}0.8341^{+*} \\
(0.0000)\end{array}$ & $\begin{array}{l}0.8774^{+3+4} \\
(0.0000)\end{array}$ & $\begin{array}{l}0.9172^{+*+} \\
(0.0000)\end{array}$ & $\begin{array}{l}0.7623^{+*+1} \\
(0.0000)\end{array}$ & $\begin{array}{l}0.8865^{+3+} \\
(0.0000)\end{array}$ & $\begin{array}{l}0.7669^{\prime \prime \prime} \\
(0.0000)\end{array}$ & $\begin{array}{l}0.8874^{+m} \\
(0.0000)\end{array}$ \\
\hline$\delta_{1}$ & $\begin{array}{l}0.0014^{* *} \\
(0.0044)\end{array}$ & $\begin{array}{l}0.0003^{*+1} \\
(0.0270)\end{array}$ & $\begin{array}{l}0.0024^{*+*} \\
(0.0002)\end{array}$ & $\begin{array}{l}0.0002 \\
(0.1692)\end{array}$ & $\begin{array}{l}0.0003^{+} \\
(0.0897)\end{array}$ & $\begin{array}{l}0.0007^{7+*} \\
(0.0455)\end{array}$ & $\begin{array}{l}0.0008^{\text {tat }} \\
(0.0040)\end{array}$ & $\begin{array}{l}0.0005^{\text {that }} \\
(0.0169)\end{array}$ & $\begin{array}{l}0.0021^{++2+} \\
(0.0004)\end{array}$ & $\begin{array}{l}0.0007^{*} \\
(0.0788)\end{array}$ & $\begin{array}{l}0.0009^{+* *+1} \\
(0.0071)\end{array}$ & $\begin{array}{l}0.0006^{+*} \\
(0.0002)\end{array}$ \\
\hline$\delta_{2}$ & $\begin{array}{l}0.0016^{6+*} \\
(0.0001)\end{array}$ & $\begin{array}{l}0.0005^{4+4} \\
(0.0003)\end{array}$ & $\begin{array}{l}0.0019^{+* *+1} \\
(0.0003)\end{array}$ & $\begin{array}{l}0.0008^{+4+1} \\
(0.0000)\end{array}$ & $\begin{array}{l}0.0007^{7+2} \\
(0.0003)\end{array}$ & $\begin{array}{l}0.0012^{2+*} \\
(0.0000)\end{array}$ & $\begin{array}{l}0.0009^{+3+t} \\
(0.0002)\end{array}$ & $\begin{array}{l}0.0010^{+* 4+} \\
(0.0000)\end{array}$ & $\begin{array}{l}0.0020^{+3+1} \\
(0.0001)\end{array}$ & $\begin{array}{l}0.0012^{\text {tw+ }} \\
(0 . .0001)\end{array}$ & $\begin{array}{l}0.0013^{* *+} \\
(0.0000)\end{array}$ & $\begin{array}{l}0.0006^{6+2} \\
(0.0000)\end{array}$ \\
\hline
\end{tabular}

Notes: The estimations are based on Equation 6 . The lag order are determined by Akaike and Schwarz information criteria. The values in () are p-values. The signs of ***,
$* *$ * denote the significance level at $1 \%, 5 \%, 10 \%$ respectively. $\delta_{1}$ and $\delta_{2}$ are the dummy variable coefficients for crisis period and COVDI-19 pandemia period. Positive and significantly estimated dummy variable coefficients reveal the presence of financial contagion. The values of technology and telecommunication sectors for Brazil and France couldn't be reached. 
Table 6. Summarize results of financial contagion

\begin{tabular}{|c|c|c|c|c|c|c|}
\hline \multicolumn{7}{|c|}{ Financial contagion of regional stock markets } \\
\hline & Turkey & China & Brazil & France & Italy & United Kingdom \\
\hline Crisis & $\mathrm{C}^{*+}$ & $\mathrm{C}^{\mathrm{sus}}$ & $\mathrm{D}$ & $\mathrm{C}^{*+s+\alpha}$ & $\mathrm{C}^{*+\infty}$ & $\mathrm{D}$ \\
\hline COVID-19 & $\mathrm{C}^{\mathrm{sen}}$ & $\mathrm{C}^{\mathrm{s+n}}$ & $\mathrm{C}^{\mathrm{kn+}}$ & $\mathrm{C}^{\text {sat }}$ & $\mathrm{C}^{\mathrm{n}+\mathrm{n}}$ & $\mathrm{C}^{*+\infty}$ \\
\hline \multicolumn{7}{|c|}{ Financial contagion of regional real economy sectors (crisis period) } \\
\hline & Industry & Metarial & Financials & Energy & Technology & Telecomunications \\
\hline Turkey & $\mathrm{C}^{*}$ & $\mathrm{C}^{\text {tan }}$ & $\mathrm{C}^{*}$ & $\mathrm{C}^{* \infty}$ & $\mathrm{C}^{\mathrm{knt}+\mathrm{t}}$ & $\mathrm{C}^{\text {sat }}$ \\
\hline China & $\mathrm{C}^{\mathrm{s}+\mathrm{s}}$ & $\mathrm{C}^{\sin \mathrm{x}}$ & $\mathrm{C}^{\mathrm{s}+\mathrm{s}}$ & $\mathrm{C}^{2 *+4}$ & $\mathrm{C}^{n+k+1}$ & $\mathrm{C}^{\sin x}$ \\
\hline Brazil & $\mathrm{D}$ & $\mathrm{D}$ & $\mathrm{D}$ & $\mathrm{D}$ & - & - \\
\hline France & $\mathrm{C}^{* *}$ & $\mathrm{C}^{\mathrm{s+n}}$ & $\mathrm{C}^{\mathrm{sin}}$ & $\mathrm{C}^{* *}$ & - & - \\
\hline Italy & $\mathrm{C}^{* *}$ & $\mathrm{C}^{\text {*** }}$ & $\mathrm{C}^{n+4}$ & $\mathrm{D}$ & $\mathrm{C}^{n}$ & $\mathrm{C}^{* * * *}$ \\
\hline $\begin{array}{l}\text { United } \\
\text { Kingdom }\end{array}$ & $\mathrm{C}^{s+n}$ & $\mathrm{C}^{\sin }$ & $\mathrm{C}^{*+*+1}$ & $\mathrm{C}^{*}$ & $\mathrm{C}^{*+1+\alpha}$ & $C^{* * * *}$ \\
\hline \multicolumn{7}{|c|}{ Financial contagion of regional real economy sectors (COVID-19 period) } \\
\hline & Industry & Metarial & Financials & Energy & Technology & Telecomunications \\
\hline Turkey & $\mathrm{C}^{\mathrm{sen}}$ & $\mathrm{C}^{\mathrm{nat}}$ & $\mathrm{C}^{n+3+}$ & $\mathrm{C}^{\mathrm{sen}}$ & $\mathrm{C}^{\mathrm{nath}}$ & $\mathrm{C}^{\text {nas }}$ \\
\hline China & $\mathrm{C}^{*}$ & $\mathrm{C}^{\sin }$ & $\mathrm{C}^{\mathrm{*} *}$ & $\mathrm{D}$ & $\mathrm{C}^{* *}$ & $\mathrm{D}$ \\
\hline Brazil & $\mathrm{C}^{\mathrm{s}+\mathrm{s}}$ & $\mathrm{C}^{\sin }$ & $\mathrm{C}^{*+*}$ & $\mathrm{C}^{* * *}$ & - & - \\
\hline France & $\mathrm{C}^{\sin +x}$ & $\mathrm{C}^{n+1+x}$ & $\mathrm{C}^{n+4+x}$ & $C^{n+2 x}$ & - & - \\
\hline Italy & $C^{s+n}$ & $\mathrm{C}^{\sin x}$ & $\mathrm{C}^{n+1+}$ & $C^{\sin s}$ & $\mathrm{C}^{n+1+x^{2}}$ & $C^{\sin x}$ \\
\hline $\begin{array}{l}\text { United } \\
\text { Kingdom }\end{array}$ & $\mathrm{C}^{*+*}$ & $\mathrm{C}^{s+x}$ & $\mathrm{C}^{\mathrm{s}+\mathrm{s}}$ & $C^{* * *+}$ & 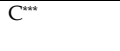 & $\mathrm{C}^{* * *}$ \\
\hline
\end{tabular}

Notes: The results are based on Equation 6. The lag order are determined by Akaike and Schwarz information criteria. The signs of ***,**,* denote the significance level at $1 \%, 5 \%, 10 \%$ respectively. (C) indicates financial contagion, (D) indicates financial dependence. The values of technology and telecommunication sectors for Brazil and France couldn't be reached

Table 6 shows summarize results of financial contagion for aggregate regional stock markets and regional real economy sectors. In the table in question, (C) indicates financial contagion (positive and significantly estimated dummy coefficients) and (D) indicates financial dependence (not significantly estimated dummy coefficients). According to the results, it can be stated that financial contagion for aggregate regional stock markets and regional real economy sectors are valid for all countries due to COVID-19 pandemia. These results can be explained by change in inverstors' risk appetite due to uncertainty and anxiety to be caused by COVID-19 pandemia. Because of the fact that COVID-19 pandemia become suddenly widespread, most of countries has had to applied social distance measures to decrease spread rate of COVID-19 pandemia, causing to increase economic cost. Future expectations on economy remain uncertain in spite of carrying into some fiscal and monetary incentive policies to reduce the effect of economic cost. This leads to global financial contagion effect in financial and non-financial sectors. 


\section{CONCLUSION}

This paper analyzed two financial contagion channels on aggregate regional stock markets and regional real economy sectors during the COVID-19 pandemi period, as well as different crisis period. From the emprical results, it was inferred that there is finanial contagion of real economy for all countries in this study during the COVID-19 pandemia period. The sector mostly affected by COVID-19 pandemia is energy in Turkey and Brazil, while it is financial sector in China, France, Italy and United Kingdom. Also, Brazil is mostly affected country by so-called pandemia because it is second country with the highest number of cases and total deaths and this creates uncertainity and pressure on perception of investors. The findings support Baur (2012) and Kenourgios and Dimitriou (2015).

These results imply that expectations regarding to economic activity will deteriorated because of the fact that world trade volumes has fallen away due to COVID-19 pandemia lead to decrease aggregate regional stock markets and sectors. Therefore, this refers that there is a shift in risk appetite of investors.

The effect of COVID-19 pandemia crisis on regional financial and non-financial sectors financial and non-financial sectors (real economy sector) may be expressed by several reasons. Firstly, unlike previous financial shocks, the COVID-19 pandemia has caused a fall in world economic activity simultaneously. Secondly, uncertainity related to so-called pandemia has still contiuned. Finally, global financial system affects directly non-financial sectors. 


\section{REFERENCES}

Ahmad, W., Sehgal, S. and Bhanumurthy, N.R. (2013), Eurozone crisis and BRIICKS stock markets: contagion or market interdependence?, Economic Modelling 33, 209-225.

Akhtaruzzamana, M., Boubakerb, S., Sensoy, A. (2020). Financial Contagion During COVID19 Crisis. Finance Research Letters.

Apergis, N., Christou, C. and Kynigakis, I. (2019). Contagion across US and European financial markets: Evidence from the CDS markets. Journal of International Money and Finance 96, $1-12$.

Baillie, R.T., Bollerslev, T. and Mikkelsen, H.O. (1996) Fractionally Integrated Generalized Autoregressive Conditional Heteroskedasticity. Journal of Econometrics, 74, 3-30.

Baker, S.R., Bloom, N., Davis, S.J., Kost, K.J., Sammon, M.C., Viratyosin, T. (2020). The Unprecedented Stock Market Impact of COVID-19. NBER Working paper, 26945.

Baur, D. (2013). The Structure and Degree of Dependence: A Quantile Regression Approach. Journal of Banking and Finance 37(3), 786-798.

Baur, D.G., 2012. Financial contagion and the real economy. Journal of Banking and Finance 36, 2680-2698.

Bekaert, G., Ehrmann, M., Fratzscher, M., Mehl, A., 2014. Global crises and equity market contagion. Journal of Finance, American Finance Association, vol. 69(6), pages 2597-2649,

Black, F., 1972. Capital market equilibrium with restricted borrowing. The Journal of Busisness $45,444-454$.

Bollerslev, T. (1986). Generalized Autoregressive Conditional Heteroskedasticity. Journal of Econometrics, 31(3), 307-327

Chandar, N.; Patro, D.K. and Yezegel, A. (2009). Crises, Contagion and Cross-Listing. Journal of Banking and Finance 33, 1709-1729.

Congressional Research Service, 2020. Global Economic Effects of COVID-19 Retrieved from. https://crsreports.congress.gov.

Conlon, T., McGee, R. (2020). Safe Haven or Risky Hazard? Bitcoin during the Covid-19 Bear Market. In: Bitcoin during the Covid-19 Bear Market (March 24, 2020).

Corbet, S., Hu, Y., Lucey, B.M., Oxley, L. (2020). Aye Corona! The Contagion Effects of Being Named Corona During the COVID-19 Pandemic. In: The Contagion Effects of Being Named Corona during the COVID-19 Pandemic (March 26, 2020).

Dimitriou, D., Kenourgios, D. and Simos, T. (2013). Global financial crisis and emerging stock market contagion: a multivariate FIAPARCH-DCC approach. International Review of Financial Analysis 30, 46-56.

Dimitris Kenourgios *, Dimitrios Dimitriou (2015). Contagion of the Global Financial Crisis and the real economy: A regional analysis. Economic Modelling 44 (2015) 283-293

Dungey, M, Fry, R.A., Gonzalez-Hermosillo, B., Martin, V.L: and Tang, C. (2010). Are Financial Crises Alike. From the 1998 Russian/LTCM crisis to the 2007 Supbrime Decable and Liquidity Crisis. IMF Working Paper No. 10/14.

Engle, R. (2002). Dynamic Conditional Correlation A Simple Class of Multivariate Generalized Autoregressive Conditional Heteroskedasticity Models. Journal of Business and Economic Statistics, 20(3)

Forbes, K. ve Rigobon, R. (2002). No Contagion, Only Interdependence: Measuring Stock Market Comovements. The Journal of Finance. 57(5): 2223-2261.

Gai, P. and Kapadia, S. (2010). Contagion in financial networks. Working Paper, 383, March. London: Bank of England. Retrieved from

http://www.bankofengland.co.uk/publications/Documents/workingpapers/wp383.pdf https://www.imf.org/en/Topics/imf-and-covid19/Policy-Responses-to-COVID-19\#T 
Kolb, R. W. (2011). Financial Contagion: The Viral Threat to the Welath of Nations. Hoboken: Wiley.

Kristoufek, L. (2020). Grandpa, grandpa, tell me the one about Bitcoin being a safe haven: Evidence from the COVID-19 pandemics. arXiv preprint arXiv:2004.00047.

Kuckertz, A. et. al. (2020). Startups in Times of Crisis-A Rapid Response to the COVID-19 Pandemic. Journal of Business Venturing Insights, 13

Lintner, J., 1965. The valuation of risk assets and the selection of risky investments in stock portfolios and capital budgets. Rev. Econ. Stat. 47, 13-37.

McKibbin, W. J., Fernando, R. (2020). The global macroeconomic impacts of COVID-19: Seven scenarios.

Pericoli, M. ve Sbracia, M. (2003). A Primer on Financial Contagion. Journal of Economic Survey. 17(4), 571-608.

Ramelli, S. and Wagner, A. F. (2020). Feverish Stock Price Reactions to COVID-19. Swiss Finance Institute Research Paper, No: 20-12

Robert Peckham (2013) Economies of contagion: financial crisis and pandemic, Economy and Society, 42:2, 226-248

Segal, S. and Gerstel, D. (2020). Breaking Down the G20 COVID-19 Fiscal Response: In: Center for Strategic and International Studies (online). Washington, D.C. https:// www.csis.org/analysis/breaking-down-g20-covid19-fiscal-respone

Sharif, A., Aloui, C., Yarovaya, L. (2020). COVID-19 Pandemic, Oil Prices, Stock Market and Policy Uncertainty Nexus in the US Economy: Fresh Evidence from the Wavelet-Based Approach. In: Oil Prices, Stock Market and Policy Uncertainty Nexus in the US Economy: Fresh Evidence from the Wavelet-Based Approach

Sharpe, W.F., 1964. Capital asset prices: A theory of market equilibrium under conditions of risk. J. Finance 19, 425-442.

Suzuki, Y.; Namatame, A. and Aruka, Y. (2014). The Linkage between Financial Market and Real Economy: The Analysis with An Agent Based simulation. Miguel, Amblard, Barceló \& Madella (eds.) Advances in Computational Social Science and Social Simulation Barcelona: Autònoma University of Barcelona. https://ddd.uab.cat/pub/poncom/2014/128001/ssc14_a2014a26iENG.pdf.

Winston, A., (2020). Is the COVID-19 Outbreak a Black Swan or the New Normal? MIT Sloan Management Review.

Zhang, D., Hu, M., Ji, Q. (2020). Financial markets under the global pandemic of COVID-19. Finance Research Letters, 101528. 
Chapter 7

\section{Covid-19 and the Educational Leadership and Management}

Zafarullah Sahito, Gul Bahar Chachar

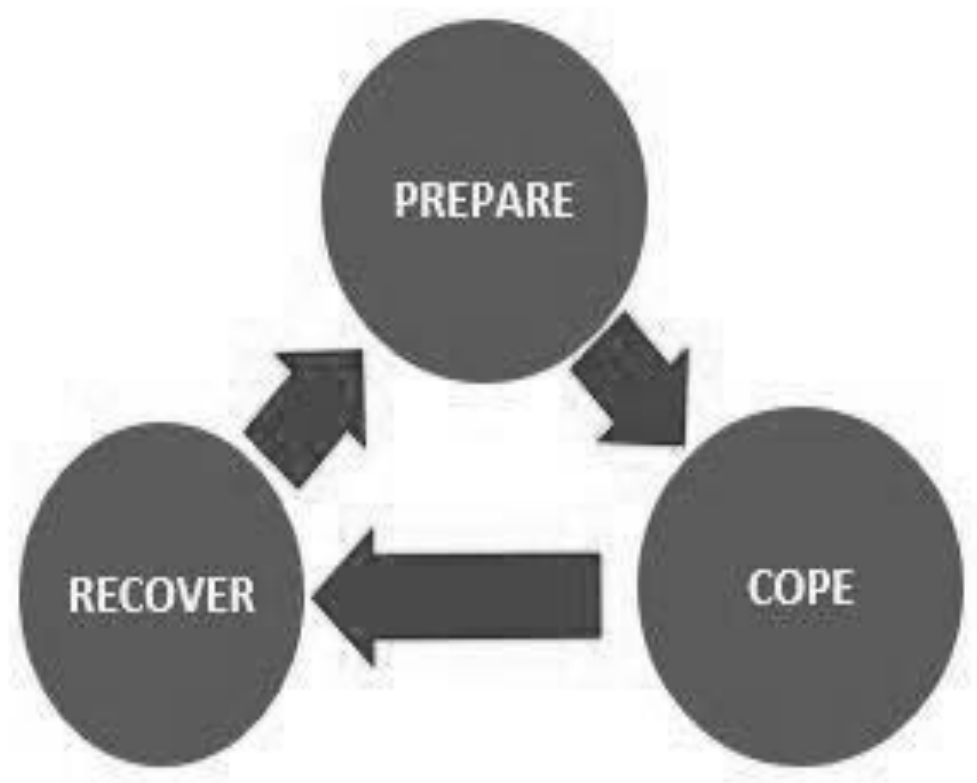

"The secret of change is to focus all of your ENERGY, Not on fighting the OLD, but on building the NEW."

(Socrates) 


\begin{abstract}
COVID-19, the novel infectious coronavirus epidemic with the defenseless spread among humans was discovered in the last quarter of 2019 in Wuhan City, China. Later, it was expanded all around the globe in the beginning of 2020, which has impacted significantly on the management of daily activities of individuals' and organizations especially on the educational organizations. Educational institutes were closed throughout the world due to the fear of the spread of COVID-19, which was found to be a deadly virus. It was confirmed after the evidence of influenza outbreak, in which a majority of the population was found affected. Despite this epidemic, many institutes throughout the world carried out their educational tasks wisely through online and set examples for others to learn. Several institutions around the globe came up with different strategies to cope up this epidemic to continue their teaching learning processes. However, the only easy and cheap strategy which was followed by the majority of the institutes was immediate closure of organizations. In the results, it almost changed the management of educational institutes and raised many questions on the future of educational management, which opened the new windows of thinking and planning to cope with the problem of present and strategies for future endeavors. There is a huge need to come up with effective management of educational organizations to think out of the box and bring the proper reforms through bold and wise initiatives to do sensible planning and implement it effectively in order to achieve the organizational predetermined goals. This chapter tries to discuss the effective strategies to cope up this challenge and highlights the role of different stakeholders for managing educational institutes effectively. Addition to this, the impact of Covid-19 on educational organizations is discussed thoroughly to bring the reforms at organizational level to support the systems to bring radical reforms from top to bottom and vice versa. In this process, the focus is to be on the perceptions of the different managements and their functions that how they considered the COVID situations as an opportunity to plan, organize, direct and control each process to improve and enhance the organizational process to achieve the goals. The functions and characteristics of Educational Leadership and Management and their engagements are to be studied in detail through the best practices of the higher education organizations.
\end{abstract}

Keywords: Covid-19, Educational Leadership and Management, Planning, Organizing, Directing and Controlling 


\section{INTRODUCTION}

COVID-19 or SARS-COV-2 is an infectious disease caused by coronavirus discovered in December 2019 in the city of Wuhan, China explore by the Centers for Diseases Control and Presentation (CDC, 2020). It belongs to the family of coronaviruses, which infect animals, humans and both. The coronavirus infected humans first in the 1960s, as there was crown-like spikes on the surface of the virus, so it was named as coronavirus. Recently discovered virus is COVID-19, which is one of the main worldwide public health concerns of the 21st century and declared as a global pandemic by World Health Organization (WHO, 2020a), affected the 50 million of the people globally (Cucinotta \& Vanelli, 2020). This virus transmitted from a person to person easily through respiratory droplets in a close contact of less than 2 meters (Murthy, Gomersall \& Fowler, 2020), and touching (WHO, 2020b). The hatching period for COVID-19 varies from a couple of days to 14 days. The indications are like cold or flu, which incorporate cough, fever, trouble in breathing, and pneumonia. The disease can be milder for certain individuals, which may send the infection to others. In addition to that the disease is more infectious, when the infected individual is more indicative, and when the viral burden is higher, the individual is more suggestive, and he or she becomes more dangerous to infect others. Coronavirus can survive on objects, and it may spread through contact with the tainted surfaces or articles, as presently demonstrated that the disease can be spread quickly and can sustain till the death of any individual. The COVID-19 has exaggerated people nevertheless of gender, income, educational qualifications and nationality (Schleicher, 2020). It infected all the persons including children, Youngers and elders at the same time. However, this pandemic is more dominant among poor or marginalized people around the world (Dugassa, 2020), who are lacking with inadequate facilities for health and living in order to enhance the immune system of their bodies.

About eighty percent $(80 \%)$ people may recover from the COVID-19 without taking any special medical treatment, because it is a minor disease for the majority of the people especially for children and young adults. As they have strong immune systems in their physical body, which make them more strong to fight against illness of COVID-19. However, for old, weak and affected people of sugar, blood pressure, heart and respiratory diseases, hypertension, etc. can be affected seriously and their illness may be increased to harm them. The infected people, who feel disturbance in their breathing are required to take hospital care, especially the people older than sixty (60) years. SARS-CoV-2 RNA has been detected in other biological samples i.e. the urine and feces of some patients, found by one and three studies respectively from the specified tested specimens. However, no more research and papers have been published to confirm the proper and authentic transmission of SARS-CoV-2 through faces or urine. In this connection, the doctors are highly recommended to avoid touching the face and take care of being away from the urine. Simultaneously, the use of soap, hand wash and sanitizers is highly recommended to use after every 20 to 30 minutes (WHO, 2020c). Because precautions can be the best measure to save themselves and others in this critical situation to be safe and healthy to fight against the deadly disease and virus. Governments play a vital role to provide the awareness to their people about this disease through different channels, mass media, social media, etc. The informative awareness and training sessions were also conducted by different international, national and local stakeholders to save the human beings from the deadly COVID-19. Furthermore, WHO advises the people of the world to consult and abide by the rules and regulations of their local, provincial, state, and federal authorities to act properly on the recommended practices in their particular area and context. An international and multidisciplinary experts group was brought together by WHO to review the collected evidences on COVID-19 disease and its transmission in children, adults and older citizens to take proper and scientific measures to avoid the critical situation especially through the precautions i.e. the use of masks, hand washing, etc. 
Humans have faced five worst pandemics in the history of mankind, i.e. the Bubonic Plague, Spanish flu, Rinderpest infection, HIV / AIDS Epidemics (Dugassa, 2020). The COVID-19 is the reminder that pandemic and disasters have occurred in the past and will continue to take place in the future (Donthu \& Gustafsson, 2020). Due to the critical conditions of Coronavirus, the millions of the children were highly impacted globally through the closure of their educational institutions. The topmost countries whose children impacted were China with 233.17; Japan with 16.50; Iran with 14.56; Italy with 9.04; Iraq with 7.01; North Korea with 4.23; Azerbaijan with 1.78; UAE with 1.17; and Lebanon with 1.13 million children respectively (UNESCO, 2020). This situation created a great loss of the students and the educational institutions, whose management and leadership remained paralyzed for a couple of months to re-think and re-plan to open their institutions. Many countries have faced different natural and artificial disasters but they never used online education as the solution of their problems. However, COVID-19 made the situation more complicated and difficult to handle in most of the countries to carry on their face to face education, which can be replicated through proper implementation of online education at all the level where applicable (Al Lily, Ismail, Abunasser \& Alqahtani, 2020) with no difference and matter of developed, developing or under developed. Similarly, Educational organizations used online meeting applications and software for conducting important meetings and organizing international conferences, seminars and talks (Kapasia et al., 2020; Sutton \& Jorge, 2020; Qazi et al., 2020). The COVID19 has helped us to understand that effective planning is the crucial need for educational organizations (Rieley, 2020) to cope up with any similar situation in the future. Because COVID-19 has created hurdles for higher education across the globe with the most important challenge that is to move from in person education to online education urgently and unpredictably (Rapanta, Botturi, Goodyear, Guàrdia, \& Koole, 2020) to be focused and sustained lifelong learning and education.

\section{OBJECTIVES OF THE CHAPTER:}

Following are the main Objectives, which have been covered in the chapter:

1. To understand the COVID-19 and its situation

2. To apprehend the Educational Leadership and Management

3. To discuss the Role of Educational Leadership and Management during COVID-19

4. To explore the Coping Strategies of Educational Leadership and Management during COVID-19 to carry on educational activities

\section{BACKGROUND}

Leadership refers to the ability to influence, modify and exercise the rules and regulations to motivate all stakeholders through making positive behavior to himself or herself, towards other members of a working group, organization and especially the achievement of personal, professional and organizational goals. It is the ability of an individual or a group of individuals to appreciate, encourage and guide each member to follow the mission of the organization and leadership to provide the knowledge, information and methods to understand, recognize and support the vision. Leadership is the ability of an individual or organization to recognize the importance of leadership in organizational development, which takes ownership through willingness to fulfill their duties and responsibilities to lead them towards success. Leadership plays an imperative role in the development of any organization through effective planning, systematic organizing, scientific directing, and authentic controlling. Because leadership is a fundamental and prime function of the management that helps them to improve, increase and enhance their productivity in order to achieve the organizational goals. The importance of leadership in organizational development cannot be 
denied because of influencing the behavior of people; helps employees in fulfilling their needs; introducing required changes; solving conflicts effectively; training and development of subordinates; setting a clear vision; motivating and guiding employees; and building the morale of all stakeholders.

Educational management links with educational administration and educational leadership, which refers to a field of study to pursue a career or a profession to work with to look after the day to day matters starting from the planning, organizing, directing and controlling in order to achieve the predetermined organizational goals. Educational management is used in the United Kingdom, Europe and Africa while educational administration is used in Canada, Australia and the United States. However, Educational leadership is the modern term for both used in the developed world (Ali \& Abdalla, 2017). Educational management plays a core role and responsibilities to administrate all the activities and tasks in the educational institutes. Education management and administration plays a prime role in the development of good human resources through upgradation of their systems and decision-making processes, which are discussed and brought in the policy, curriculum, and personnel matters to deal with the situations and solve them scientifically within the limited and pre described period of time. Educational Administration and Leadership prepares outstanding social justice leaders and change agents to create organizational conditions in order to provide opportunity to every stakeholder through transparent and meritorious systems based on justice to govern and ensure the participation to improve and enhance the administrative, academic and technological performance of all stakeholders. Education managers and leaders develop the systems, programs, departments and services to support students and faculty to complete their degree programmes i.e. undergraduate, graduate and postgraduate studies. Education managers work in the different departments related to their qualification and experiences i.e. in finance, student services, examinations, hostels, human resource, and academic administrative departments.

The main purpose of educational leadership and management is to administer the educational activities through combining and utilizing the human and material resources to supervise, plan, strategize, and implement the structures to execute an educational system (Connolly, James, \& Fertig, 2017). Because education is the process to equip the learner with the knowledge, skills, values, beliefs, habits, and attitudes through extensive and rich learning experiences. It is considered an ecosystem of professionals in educational institutions consisting of different heads, faculty, staff, administrative personnel, etc. working together to improve, enrich, enhance and execute efficiently. The educational ecosystem can be managed efficiently through effective educational leadership and management, which is the key requirement of every good educational organization to do proper planning, organize the different systems efficiently, implement rules and regulations completely, review the interventions, evaluate the processes in order to integrate everything required for success. The prime function of educational leadership and management is to enhance the productivity and maximize the efficiency of the organization to achieve the organizational goals. It is directly related to the development, which can be done through positive change in the behaviors of all stakeholders especially the heads to move forward and the development of human resources and systems. It depends on the enlisting and guiding processes of the human talents, energies and motivations to strive and achieve the common educational goals, which can be guaranteed in the shape of academic success through process, training and material development and improvement. For academic success, the creation of conducive working environments is required, which promote, support, and sustain effective teaching and learning processes. 


\section{ROLE OF EDUCATIONAL LEADERSHIP \& MANAGEMENT DURING COVID-} 19

COVID-19 has produced huge disturbance in the educational system across the globe affecting more than 1.6 billion children in 190 countries of the world (UNESCO, 2020). It was also warned by UNESCO that almost 28.3 million additional children will drop out from the education institutions because of the economic impact on their lives after the pandemic. Addition to this, most of the individuals will lose their jobs across the globe. Initially, it ruined the income of Chinese universities, which run their expenditure from national and international students (Perrota, 2020). It is predicted that 30,000 persons will be jobless in the UK (UCU, 2020), and 21,000 in Australia (Universities Australia, 2020). However, people in the US will face pay freezes, some reductions and job losses as well (DePietro, 2020). It was assumed that COVID-19 transmission will be reduced after the closure of educational institutions as it transmits from one person to others as per the evidence of influenza outbreak (Jackson, Vynnycky \& Mangtani, 2016). However, research studies across the globe highlighted that contacts continue during the school closure (Brooks et al. 2020, Eames, Tilston \& Edmunds 2011) due to COVID-19 forced educational institutions to move from in person education to online education (Beech \& Anseel, 2020) for the survival of their system and the minimization of the learning loss of the students. Most educational institutes have taken initiatives to cope up this pandemic situation after the suggestions of WHO's Education and Health department. Some of the educational institutes carried out their tasks taking the precautionary measures. There is the appearance of collective, diverse and integrative approaches of educational leaders and managers to resolve the COVID -19 pandemic globally (Kniffin e al., 2020; Van Bavel et al., 2020; Crawford et al., 2020). School closures are among the most implemented interventions around the world (Donohue \& Miller, 2020). Because it is an exceptional respiratory disease and is eventually challenge for all educational leaders (Dugassa, 2020; Qazi et al., 2020), which affected the day to day activities of all educational institutions around the world from academics to administrative activities that were found the ultimate challenge for organizational agility $(\mathrm{Wu}, 2020)$. Most of the countries have substituted face-to-face education with online education in the reaction to COVID-19 as a protective means (Al Lily, Ismail, Abunasser \& Alqahtani, 2020).They opened institutes through observing and maintaining the social distancing. However, some educational institutes allowed their faculty members for online classes and students were asked to take their classes from home, which reduces the chances of spread of coronavirus. In addition, this affected a lot of the personal lives of all the stakeholders of educational institutions and affected more on their emotional and social lives because of not having more activities outside the home. Similarly, it affected the academics of almost all persons who are connected with educational institutes of the globe no matter at what level they are teaching or studying. During this pandemic, educational leadership can overcome its problems and issues through a self-assessment technique, which helps them to examine the equity and justice that affects the diversity of all stakeholders. The core purpose of educational leadership is to assure academic success through process implementation, professional development and training; improvements of instructional and material resources. This success cannot be accomplished without the support, help and collaboration of everyone stakeholder(s) i.e. students, parents, teachers, staff, policymakers, governments and the common public. Educational leadership is a process, method and technique that can ensure the quality of academic management to reach the peak of the standardization to achieve the predetermined outcomes. The authentic process of educational leadership depends on the creation of a vision of academic success for all stakeholders to acquire the highest level of socio-economic outcomes. It aims to maintain a conducive, healthy and safe learning environment through delegation of powers and responsibilities to involve everyone based on sharing and caring principles to create 
ownership among all stakeholders. It aims to improve and upgrade the curriculum (content and instructional methods) through proper adaptation of modern tools and techniques of management, pedagogy, and research. Because, effective communication, self-regulation, time management, teamwork, motivation creation, conduction of curricular, extra-curricular or co-curricular activities, doing evaluation, maintaining and managing instructional setting, etc. are the major roles and characteristics of educational leadership and management.

\section{SOLUTIONS AND RECOMRNDATIONS}

Educational Leadership and Management (ELM) helps and encourage the faculty and students to prepare and develop their selves to cope up with the Covid situation in the following ways:

1. ELM provides the opportunity to all stakeholders to keep their teaching and learning activities live in this critical condition of Covid

2. ELM inspires the all employees to learn more about their selves in order to keep their and others safety and peace

3. ELM attracts the top talent to increase, insure and enhance the systems up to mark through innovative ideas of the proper usage of technology and other resources

4. ELM keeps remote companies together and active to support actively

5. ELM reinforces the values especially human, ethical and organizational values

6. ELM reinforces the organizational culture and working environment

7. ELM supports the stakeholders to become more important through lifelong learning

8. ELM enables the stakeholders and systems to enable themselves for better futures

9. ELM inspires others to learn more through the analysis of actual, true and real situations to reach the proper solutions of the problems

10. ELM helps to facilitate the great innovation and invention for the relief of the society and humanity

Furthermore, faculty members regarding their backgrounds and ages have to prepare and teach online from their homes and have to solve all the challenges they face without much technical support (Hodges et al., 2020). Teachers are lacking in technical and pedagogical skills for teaching online (Kali, Goodyear and Markauskaite 2011; Ching, Hsu and Baldwin2018). Similarly, faculty members are experiencing much stress and workload as they were already trying their best to balance teaching, research and other additional duties (Houlden \& Veletsianos, 2020). In addition, the COVID-19 pushed the research and academics at university level to the front position of public consideration (Lancet, 2020). Besides this, higher education institutions are facing many challenges including campus protection, new admissions processes, and online education arrangements. However, COVID-19 pandemic will have multifaceted, unpredicted and long lasting research implications that must be projected this day and age (Lancet, 2020).

Instructional and communication technologies (ICTs) is one of the emerging areas for a long time across different areas of education. Similarly, many universities claimed to be technological advanced. However, most of the universities were not prepared to act as a model for others in the time of COVID-19 pandemic (Papagiannids, Harris \& Morton, 2020). Addition to this, teachers and students are lacking in skills and competencies for integrating digital tools into the teaching-learning process (Song et al., 2020). This situation is enforced to academicians and researchers for questioning on the preparation of higher education institutions for the upcoming digital era of learning (Houlden \& Veletsianos, 2020). In this pandemic situation, an educator should focus on five important things effectively including 
Guidelines, content, inspiration, connections, and psychological wellbeing of individuals (Martin, 2020). It would be better for an influential leader to follow these things as well. Disasters and pandemics can arouse our enthusiasm for the implementation of ICTs and electronic learning tools (Tull et al., 2017). In this regard, one study is cited here that was an exploratory empirical research was conducted in Finland and India on digital transformation of education caused by coronavirus (Iivari, Sharma \&Ventä-Olkkonen, 2020). In Finland, teachers were using technology for the teaching-learning process before the pandemic. As a teacher mentioned that she has been using Google Classroom for over five years so the situation does not take any serious challenges for teacher and children. Similarly, teachers were already using technological tools for teaching in private and public schools in the setting of special schooling in India.

Arabs who are considered deeply entrenched for their social closeness, are also following social distancing in their educational institutions and replacing online education with face-toface education (Al Lily, Ismail, Abunasser \& Alqahtani, 2020). COVID-19 has impacted significantly on all the aspects of life especially the education sector around the world. As Crawford et al., (2020) highlighted the responses of higher education institutions across the 20 countries of the world. They underlined that almost all countries have closed the campuses and moved to online education. Some of the countries including China, Hong Kong, India, South Africa and South Korea have extended their dates for academic activities. The Ministry of Education, China decided to delay all the educational activities including classes, entrance tests and international examinations (Khaliq, 2020). The Government of Egypt shut downed all the educational institutions in the country (Ahram, 2020; Reuters, 2020). The Government of Hong Kong suspended all schools (Zhang et al., 2020) and announced extension in the Holidays and decided to implement online education for continuing semester (Lau et al., 2020). The Government of India had not announced to shut down schools in the initial days (Mansoor, 2020). The Government of Indonesia had cancelled all the exams (Ghaliya, 2020). The ministry of University and Research Italy announced online learning using Skype in March 2020 (De Giorgio, 2020). The Jordan Government closed all educational institutions (Ashara -Al Wasat, 2020) and decided to teach online (Khaberni, 2020). Many universities in Malaysia announced to conduct online classes (Lim, 2020). National Universities Commission, Nigeria ordered to close all the universities in the country (Ezeri, 2020). All the universities and colleges were closed in South Africa and they were advised to discover digital means for teaching (Chothia, 2020). School and University classes were cancelled in Latin America (Montanez, 2020). Same conditions were observed in Pakistan, where the higher education commission (HEC) suggested the universities, colleges and schools to go online after consultation with federal and provincial Governments. Unfortunately, many universities, schools and colleges were not found up to mark with online facilities to deal with the COVID19 pandemic situation. With the minimum passage of time, the educational leadership and management of many universities took quick initiatives to bring radical reforms and steps to start the online classes, but still there is a dire need of scientific interventions to deal with the situation. In this regards, the funds of million rupees were issued by federal and provincial Governments to universities through HEC to upgrade the ICT systems.

\section{FUTUER RESEARCH DIRECTIONS}

This area has the potential to explore more by conducting qualitative, quantitative and mix method research studies to get more useful and scientific insights about the issues and possible strategies to cope up with the problems of COVID-19 with especial relation to educational leadership and management. 


\section{CONCLUSION}

This chapter discusses the major issues, problems and challenges, their coping strategies and impact of COVID-19 on our educational systems and daily routine practices of teaching learning processes. This virus is very dangerous because it can survive for many days and transmit through the respiratory tract in any human being. The people who have a strong immune system can easily defeat this virus and can donate their plasma for other patients. Further, the role of different stakeholders are discussed for taking initiative that could address these new normal problems. Additionally, the quality of education is compromised due to transfer to the online educational system. The students who do not have access to the technology and internet facilities are facing a lot of adversities in their educational career. The role of educational leadership and management discussed encouraging and motivating faculty to learn needed base skills for effective classroom practices. The teachers' professional development is one of the best strategies to prepare teachers for this emerging situation. As online teaching and learning has become well-known nowadays, teachers need to learn how to teach online and ensure the quality education. 


\section{REFERENCES}

Ahram Online. (2020, March 14). Egypt Closes Schools and Universities for Two Weeks over Coronavirus Concerns.

http://english.ahram.org.eg/NewsContent/1/64/365268/Egypt/Politics-/Egyptcloses-schools-and-universities-for-two-week.aspx

Al Lily, A. E., Ismail, A. F., Abunasser, F. M., \& Alqahtani, R. H. A. (2020). Distance education as a response to pandemics: Coronavirus and Arab culture. Technology in Society, 63, 101317.

Beech, N., \& Anseel, F. (2020). COVID-19 and Its Impact on Management Research and Education: Threats, Opportunities and a Manifesto. British Journal of Management, 31(3), 447-449.

CDC (2020) Human Coronavirus Types. https://www.cdc.gov/coronavirus/types.html accessed $25^{\text {th }}$ November 2020

Ching, Y. H., Hsu, Y. C., \& Baldwin, S. (2018). Developing computational thinking with educational technologies for young learners. Tech Trends, 62(6), 563-573.

Chothia, A. (2020, March 17). Coronavirus outbreak closes all South African universities, colleges. The South African. https://www.thesouthafrican.com/news/coronavirussouth-african-universities-colleges-closed-nzimande

Connolly, M., James, C., \& Fertig, M. (2017). The difference between educational management and educational leadership and the importance of educational responsibility. Educational Management Administration \& Leadership, 47 (4), 504-519. Doi: $10.1177 / 1741143217745880$

Crawford, J., Butler-Henderson, K., Rudolph, J., Malkawi, B., Glowatz, M., Burton, R., ... \& Lam, S. (2020). COVID-19: 20 countries' higher education intra-period digital pedagogy responses. Journal of Applied Learning \& Teaching, 3(1), 1-20.

Cucinotta, D., \& Vanelli, M. (2020). WHO declares COVID-19 a pandemic. Acta Bio Medica: Atenei Parmensis, 91(1), 157.

De Giorgio, T. (2020, February 26). Coronavirus in Lombardy, at the Politecnico di Milano the degree thesis is discussed via Skype [Italian]. La Repubblica. https://milano.repubblica.it/cronaca/2020/02/26/news/coronavirus_in_lombardia al_politecnico_di_milano_la_tesi_di_laurea_si_discute_via_skype-249628719/

De Pietro, A. (2020). A Look at the impact of Coronavirus on Colleges and Universities in the US. Forbes: https://www.forbes.com/sites/andrewdepietro

Donohue, J. M., \& Miller, E. (2020). COVID-19 and school closures. Jama, 324(9), 845-847.

Donthu, N., \& Gustafsson, A. (2020). Effects of COVID-19 on business and research. Journal of business research, 117, 284.

Dugassa, B. F. (2020). What can we Learn from the Past Deadly Pandemics and Prepare to Curb COVID-19? The Case in Oromia Regional State in Ethiopia. American Journal of Public Health, 8(2), 67-76.

Ghaliya, G. (2020). Indonesia scraps national exams due to COVID-19. The Jakarta Post. https:// www.thejakartapost.com/news/2020/03/24/indonesia-scraps-nationalexams-due-to-COVID-19.html

Hodges, C., Moore, S., Lockee, B., Trust, T., \& Bond, A. (2020). The difference between emergency remote teaching and online learning. Educause Review, 27 March. https://er.educause.edu/articles/2020/3/thedifference-between-emergencyremote-teaching-and-online-learning. Accessed 25 November 2020

Houlden, S., \& Veletsianos, G. (2020). The problem with flexible learning: Neoliberalism, freedom, and learner subjectivities. Learning, Media and Technology, 1-12 
Iivari, N., Sharma, S., \& Ventä-Olkkonen, L. (2020). Digital transformation of everyday lifeHow COVID-19 pandemic transformed the basic education of the young generation and why information management research should care? International Journal of Information Management, 55, 102183.

Kali, Y., Goodyear, P., \& Markauskaite, L. (2011). Researching design practices and design cognition: contexts, experiences and pedagogical knowledge-in-pieces. Learning, Media and Technology, 36(2), 129-149.

Kapasia, N., Paul, P., Roy, A., Saha, J., Zaveri, A., Mallick, R., ... \& Chouhan, P. (2020). Impact of lockdown on learning status of undergraduate and postgraduate students during COVID-19 pandemic in West Bengal, India. Children and Youth Services Review, 116, 105194.

Khaberni. (2020). Universities Ready for Online Classes. https://www.khaberni.com/news

Khaliq, R. (2020). China prolongs school closure amid coronavirus outbreak. Anadolu Agency. https://www.aa.com.tr/en/asia-pacific/china-prolongs-school-closureamid-coronavirus-outbreak/1716100

Kniffin, K. M., Narayanan, J, Anseel, F., Antonakis, J., Ashford, S. P., Bakker, A. Bamberger, P., ... Van Vugt, M. (2020, in review). COVID-19 and the Workplace: Implications, Issues, and Insights for Future Research and Action. Working Paper.

Lau, J., Yang, B., \& Dasgupta, R. (2020, March 12). Will the coronavirus make online education go viral?. Times Higher Education. https://www.timeshighereducation.com/features/will-coronavirus-make-onlineeducation-go-viral

Lim, I. (2020, March 16). COVID-19: What are Malaysia's public universities doing? Online classes and more. Malay Mail. https://www.malaymail.com/news/malaysia/2020/03/16/COVID-19-what-aremalaysias-public-universities-doing-online-classes-and-mo/1847071

Mansoor, S. (2020, March 12). India is the world's second- most populous country. Can it handle the coronavirus outbreak? Time. https://time.com/5801507/coronavirusindia/

Martin, A. (2020). How to optimize online learning in the age of coronavirus (COVID-19): A 5-point guide for educators. https://www.researchgate.net/publication/339944395_How_to_Optimize_Online_ Learning_in_the_Age_of_Coronavirus_COVID-19_A_5-Point_Guide_for_Educators

Montanez, A. (2020). Number of confirmed cases of novel coronavirus (COVID-19) in Latin America and the Caribbean as of March 31, 2020, by country. https:// www.statista.com/statistics/1101643/latin-america-caribbean-coronaviruscases/

Murthy, S., Gomersall, C. D., \& Fowler, R. A. (2020). Care for critically ill patients with COVID19. Jama, 323(15), 1499-1500.

Qazi, A., Naseer, K., Qazi, J., AlSalman, H., Naseem, U., Yang, S., Hardaker, G., \& Gumaei, A. (2020). Conventional to online education during COVID-19 pandemic: Do develop and underdeveloped nations cope alike. Children and Youth Services Review, 119, 105582, https:// doi.org/10.1016/j.childyouth.2020.105582.

Rapanta, C., Botturi, L., Goodyear, P., Guàrdia, L., \& Koole, M. (2020). Online university teaching during and after the Covid-19 crisis: Refocusing teacher presence and learning activity. Postdigital Science and Education, 2(3), 923-945.

Reuters. (2020, March 14). Egypt shuts schools, universities for two weeks as virus cases increase. Free Malaysia Today. https://www.reuters.com/article/us-healthcoronavirus-egypt/egypt-shuts-schools-universities-for-two-weeks-as-virus-casesincrease-idUSKBN2110SH 
Schleicher, A. (2020). The Impact Of Covid-19 On Education Insights From Education At A Glance 2020. Retrieved from oecd. org website: https:// www.oecd.org/education/the-impact-of-covid-19-on-education-insightseducation-at-a-glance-2020.pdf.

Sutton, M. J., \& Jorge, C. F. B. (2020). Potential for radical change in Higher Education learning spaces after the pandemic. Journal of Applied Learning and Teaching, 3(1).

Tull, S., Dabner, N., \& Ayebi-Arthur, K. (2017). Social media and e-learning in response to seismic events: Resilient practices. Journal of Open, Flexible, and Distance Learning, 21(1), 63-76.

Universities Australia (2020) https://www.universitiesaustralia.edu.au/media-item/univiability-crucial-to-national-recovery

University and College Union [UCU] COVID-19 Report: https:// www.ucu.org.uk/article/10759/Universities

Van Bavel, J. J., Baicker, K., Boggio, P. S., Capraro, V., Cichocka, A., Cikara, M., ... \& Drury, J. (2020). Using social and behavioural science to support COVID-19 pandemic response. Nature Human Behaviour, 1-12.

World Health Organization [WHO] (2020a). WHO Director-General's opening remarks at the media briefing on COVID-19 11 March 2020. https://www.who.int/directorgeneral/speeches / detail/who-director-general-s-opening-remarks-at-the-mediabriefing-on-covid-19---11-march-2020

World Health Organization [WHO] (2020b). Coronavirus disease (COVID-19) pandemic. https:// www.who.int/emergencies/diseases/novel-coronavirus-2019

World Health Organization [WHO] (2020c). Coronavirus Disease (COVID-19) advice for the public. $\quad$ https://www.who.int/emergencies/diseases/novel-coronavirus2019/advice-for-

public\#: :text=If $\%$ 20COVID $\% 2$ D19\%20is $\% 20$ spreading,a $\%$ 20bent $\% 20$ elbow $\% 20$ or $\% 2$ Otissue.

$\mathrm{Wu}, \mathrm{Z}$. (2020). How a top Chinese university is responding to coronavirus. https:// www.weforum.org/agenda/2020/03/coronavirus-china-the-challenges-ofonline-learning-foruniversities/

Zhang, K., Cheng, L., Sum, L., Chung, K., \& Cheng, Z. (2020, March 21). Coronavirus: Critical phase looms for Hong Kong as Carrie Lam revives working from home, postpones exams. South China Morning Post. https://www.scmp.com/news/hongkong/politics/article/3076274/coronavirus-hong-kong-civil-servants-return-workhome 


\title{
Chapter 8
}

\section{Effect of Happy 8 Workplace and Corporate Social Responsibility on Success of Small and Medium Enterprises in Thailand during Covid-19}

Kittisak Jermsittiparsert

\begin{abstract}
Happy 8 workplace means happy and satisfied employees are working at the workplace. This happy workplace or happy workers of corporation increase the performance of the company. Another factor that contributes to higher performance is corporate social responsibility means societal and philanthropic work from organizations. This current study also wants to explore the relationship between the Effect of Happy 8 Workplace and Corporate Social Responsibility on Success of Small and Medium Enterprises among employees working in small and medium enterprises functioned in Thailand. Data is collected through a questionnaire via a drop-down survey method. Items related to variables taken from previous studies. Results generated from collected data indicate that Happy 8 workplace and corporate social responsibility have a positive significant impact on the success of small and medium enterprises. Corporate social responsibility also has a positive impact on workforce orientation and workforce orientation also mediates the relation between corporate social responsibility and the success of small and medium enterprises. The current study gives recommendations to policymakers that they should focus on the Happy 8 workplace and corporate social responsibility for increasing the success of small and medium enterprises.
\end{abstract}

Keywords: Happy 8 Workplace, Corporate Social Responsibility, Success of Small and Medium Enterprises, Workforce Oriented, Covid-19, Thailand 


\section{INTRODUCTION}

Happy employees are those employees who care about their company, work for their goals and vision. Happy employees consider their organization and its goals at priority. Employees who are happy at their workplace, work efficiently, effectively, and more obliged to their duties. Happy employees are simply employees who are more satisfied, loyal, engaged, and committed. These types of employees give more spark to organizations and heartedly work for it. Happy employees are 10 percent more productive than average and unhappy employees are 10 percent less productive than average. Advantages of Happy 8 workplace other than the satisfaction and more productivity are higher retention, low turnover rate, batter environment, and more harmonized workplace environment. Seven major factors make the employees happier than average like, sagacity of determination, feeling appreciated, obtainability of wellness plans, and sentiment of affianced, operational in a cooperative atmosphere, not having rigidity, and presence in constructive workplace culture (Crawford, Butler-Henderson, Rudolph, \& Glowatz, 2020).

Another factor that increases the productivity of an organization is corporate social responsibility. (Thongrawd, Bootpo, Thipha, \& Jermsittiparsert, 2019) Corporate social responsibility is a self-regulated model of business to do companies more social. Corporate social responsibility aims to involve the organization in philanthropic work or work for societal welfare. Corporate social responsibility is considered as the upper-level concept to engage the companies and business with their stakeholders and force the organization to do work for societal welfare and show some environmental concerns. Corporate responsibility is also related to the sustainability of businesses over the long term. Corporate social responsibility aims to add value to the company or in business by ensuring that this business or company works for the environment and has a positive impact on society and the community. There are some benefits of corporate social responsibility improved product appreciation, encouraging corporate status, an increase in transactions, and also increase buyer devotion, increase in performance, staff retention, increase in growth, and increase in assets (Ghislieri, Molino, \& Cortese, 2018).

Corporate social responsibility has four levels, one is economic, legal, ethical, and philanthropic. The first level of corporate social responsibility is to earn a profit, second is to follow the legal commitments, third is to perform their duties, production and supply chain on an ethical level and fourth or last level of corporate social responsibility are to work for the welfare of society. Corporate social responsibility works for improving the image of an organization in the eyes of employees, buyers, suppliers, and society. Mangers of different organizations or industries understand the importance of corporate social responsibility concept and willing want to contribute some resources for social or societal welfare (Dean \& Spoehr, 2018).

Small and medium enterprises are businesses of small and medium level. These small and medium level businesses have some financial and human resource limits than large corporations and businesses. Small and medium enterprises are also called non-subsidiary firms. Small and medium enterprises play an important role in the development of the economy. This important role is related to, production, employment generation, and contribution to exports. In small and medium enterprises income level distribution is very low but this sector also provides part-time jobs to a large number of poor people. Small and medium enterprises are also the source of entrepreneurship, innovation, and creativity in the economy (Romero et al., 2016). 
Small and medium enterprises are an important sector for the Thai economy this sector of the industry largely contributes to the gross domestic product, exports, production and gives a large number of jobs in Thailand. Approximately three million small and medium enterprises are working in Thailand. With the growing importance of this sector, this sector also faces many challenges like lack of marketing budget and lack of marketing knowledge showed in Figure 1. Some issues of small and medium enterprises are related to the less support of the government of Thailand (Eberhard et al., 2017). Public policy, government financial support, knowledge, capital, labor, fewer resources, low machinery, and fewer plants are some challenges faced by small and medium enterprises in Thailand.

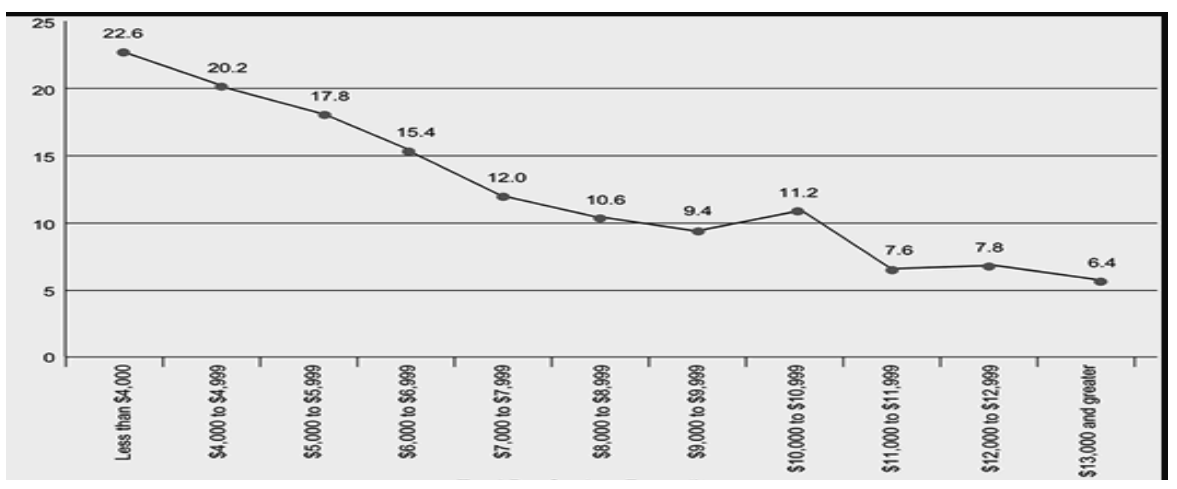

Figure 1. Small and medium enterprises performance (2020)

Studies that are present in previous literature argued that happy employees that are working in an organization are a great source of success and an increase in performance. Studies also argued that corporate social responsibility and work of the organization in term of workforce orientation is considered as the major source of success (Lee et al., 2018). Due to these studies, this current stud also aimed to analyze the impact of the Effect of Happy 8 Workplace and Corporate Social Responsibility on Success of Small and Medium Enterprises among employees working in small and medium enterprises functioned in Thailand. The theoretical framework of this study is represented in Figure 2. Happy 8-workplace and corporate social responsibility are independent variables, workplace orientation is the mediator, and the success of small and medium enterprises is as the dependent variable in this study.

The objective of this current study is 1) to analyze the impact of Happy 8 Workplace on Success of Small and Medium Enterprises. 2) To analyze the impact of corporate social responsibility on the Success of Small and Medium Enterprises and workforce orientation. 3) To analyze the impact of workplace orientation on the success of small and medium enterprises and also the mediation of workplace orientation in between corporate social responsibility and success of small and medium enterprises.

Various studies analyzed the impact of the Happy 8 workplace and corporate social responsibility on the success of the different organizations. But all these studies were not conducted on the small and medium enterprises of Thailand. This current study is a vital contribution in previous literature by studying the impact of the Happy 8 workplace and 
corporate social responsibility on the success of small and medium enterprises of Thailand. This study has many theoretical and practical contributions.

\section{LITERATURE REVIEW}

Happy organizations have a competitive advantage on the others. This believes it so strong and he uses to give the class of happiness to his employees. He understands that happy employees are the key to success for the organization. He uses to convince the entrepreneurs to start new businesses with happy employees at the core of the business and that should be the central part of the business. Emerging researchers are focusing on the positive attributes of the employees to increase the well-being of employees. They understand that happy human resource produces better results. Happiness is a feeling of positive psychology. Happiness is most often conceptualized as "subjective wellbeing, or thinking and feeling positive about one's health, relationships, work, and overall life" (Selamat, Alias, Hikmi, Puteh, \& Tapsi, 2017).

Businesses from the start are part of society. They have been working for the development of societies every business promotes the job and contributes toward the economy. Most of the businesses take part in the welfare of society. No social responsivity is determined by every business. Social responsibility gives respect to the business and makes an image for the customers. Goodwill of the business also depends on social responsibility. Many businesses are attracting customers due to their focus on social responsibility. Small and medium enterprises are also responsible for corporate responsibility. The focus of the current study is to measure the impact of the Happy 8 workplace and corporate social responsibility on the success of small and medium enterprises.

\section{Happy 8 Workplace and Success of SMEs}

There are different scopes of happiness. Different organizations in some areas to make the employees happy and satisfy. Tension in any area of life can affect performance. Happy 8 is the new concept of study which covers mostly all of the aspects of being happy most of the organizations are now focusing to keep the worker happy inside and out of the organization. They take care of them in every aspect. It has been observed and concluded from many studies that if an employee is given every facility at work and has no complaints about the system but facing any issue at the private life cannot perform well on the job also. Happy at concept covers the 8 major areas of a person's life, these are happy body, happy heart, happy relax, happy brain, happy soul, happy money, happy family, and happy society. If a person is satisfied with all these aspects, chances are very low to be unsatisfied. Modern organizations are trying to make the customer happy in all these areas so that employees can work freely and happily for the organization to produce maximum output.

Corporate social responsibility is to work for the welfare of the environment and society. It needs to protect the environment from the hazards. Many businesses are operating and producing waste. Most of them are very harmful. There exist many other issues in society. It the responsibility of the business to contribute the society for the well-being (Oosthuizen, 2016).

SEMs are small and medium enterprises. These enterprises are small startups of different businesses and nonprofit organizations. It's a new concept, people are taking their startups at a very small level to be entrepreneurs. It helps the economy a lot to be people independent and produce new income opportunities. Happy workplace matters everywhere small and medium enterprises are also operated by human resources. If they will be happy and satisfied with the 
environment their performance and interest can be increased. Similarly, corporate social responsibility should also be taken by the SMEs they work on a small level but it can produce a good image and goodwill for the enterprises. Both factors can help these small enterprises to grow and exist. From the discussion we may assume that:

H1: Happy 8 workplace significantly affects the success of SMEs.

\section{Corporate Social responsibility and Workforce Oriented SMEs}

As discussed, corporate social responsibility is a welfare step. It was voluntarily taken by the organization in the past but now its responsibility to perform these activities. Work forceoriented SMEs are the enterprises that are much care full about their workforce and their maximum operations depend on the workforce other than the technology. SMEs are a type of workforce organizations. When a social welfare activity is performed, this is not limited to the external environment. Internal environment of the organization is also supporting these kinds of activities to be promoted for the labor of organization. In a way a caring organization become more responsible for their employees (Gleason, 2018). Very few studies have been conducted on the relevant topics. Objective of the study is to cover the gap of literature by analyzing the impact of corporate social responsibility on the workforce-oriented SMEs of Thailand. A hypothesis can be formulated in a way to test the assumption:

H2: Corporate social responsibility has significant impact on the Success of workforce-oriented SMEs.

\section{Workforce Oriented SMEs and Success of SMEs}

Trend of SMEs are increasing day by day. After COVID-19 when economy of the whole world is affected badly. Growth of the countries has declined. Unemployment rate is increasing more. In this situation there need a boost to handle the economy. There are many ways to control but most effective is take independent initiative by everyone to support themselves and others. SMEs are the most effective form of these initiatives. These initiatives give the opportunities to take startups and earn profit by doing small businesses. These are the small level initiatives that are taken at the micro level but later these micro variables form the macroeconomic. The happiness of the individual comprises all. People working in the SMEs are satisfied then they can work with zeal. SMEs like workforce oriented take much care of their employees. This type of SMEs structures the management and operations by the input of workforce. It gives them confidence and a sense of ownership with the organization (Zhao et al., 2020). Studies have proven that workforce-oriented organizations can perform well. Discussion can be hypothesized as:

H3: Workforce oriented SMEs have a significant impact on the success of SMEs.

H4: Workforce oriented mediates the relationship between Corporate Social Responsibility and the success of SMEs.

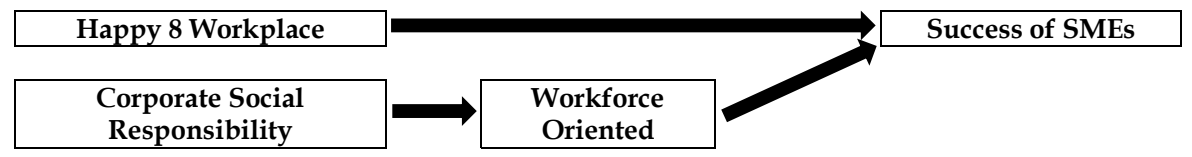

Figure 2. Conceptual framework 


\section{RESEARCH METHODOLOGY}

This current study research part tells about the collection of data, tools, and techniques that are necessary for finding the impact of the Happy 8 workplace and corporate social responsibility on the success of small and medium enterprises with the mediation of workforce orientation. Respondents of this study were employees working in the small and medium enterprises of Thailand. A quantitative research design is selected for this current research (Nadeem, Alvi, \& Iqbal, 2018). Data is collected by the questionnaire. The questionnaire includes the demographics and question related to variables like (Happy 8 workplace, corporate social responsibility, workforce oriented, and success of small and medium enterprises) are adopted from the previous studies. A simple random sampling technique is used. This simple random sampling technique is easy to handle and cheap.

Data is collected by the drop-down method. The author takes the prints of a questionnaire to respondents' place, at workplace or home. The author describes the purpose of data collection and after it collects the filed questionnaire from respondents'; place and gives them acknowledgment. By deducting the missing values and outliers 220 questionnaires used for data analysis. This 220 -sample size is considered as enough for analyzing the selected variables (Happy 8 workplace, corporate social responsibility, workforce oriented, and success of small and medium enterprises).

\section{RESEARCH RESULTS}

For analyzing Smart PLS 3 was used because PLS 3 is a better tool for complex models that have mediation and moderation effect. Measurement of reliability and validity is the first and important step in the data analysis. Factor loading and average variance extracted (AVE) should be greater than 0.5 , Cronbach's alpha and composite reliability are more than 0.7 . All values are showed in Figure 3 and Tables 2 and 3. For validity author analyzed the Cross loadings which are also depicted Table 4 .

\section{Table 1. Data Statistics}

\begin{tabular}{|c|c|c|c|c|c|c|c|c|c|}
\hline & No. & Missing & Mean & Median & Min & Max & SD & Kurtosis & Skewness \\
\hline HW1 & 1 & 0 & 1.465 & 1 & 1 & 5 & 0.698 & 2.984 & 2.149 \\
\hline HW2 & 2 & 0 & 1.654 & 2 & 1 & 4 & 2.097 & 1.127 & 0.616 \\
\hline HW3 & 3 & 0 & 1.676 & 2 & 1 & 4 & 0.635 & 0 & 1.529 \\
\hline HW4 & 4 & 0 & 1.735 & 2 & 1 & 3 & 0.633 & -0.656 & 0.285 \\
\hline CS1 & 5 & 0 & 1.897 & 2 & 1 & 4 & 0.628 & 2.026 & 0.213 \\
\hline CS2 & 6 & 0 & 1.805 & 2 & 1 & 4 & 2.062 & -0.272 & 1.351 \\
\hline CS3 & 7 & 0 & 1.892 & 2 & 1 & 4 & 0.681 & -0.468 & 0.243 \\
\hline CS4 & 8 & 0 & 2.189 & 2 & 1 & 5 & 1.02 & -0.352 & 0.599 \\
\hline CS5 & 9 & 0 & 2.043 & 2 & 1 & 5 & 0.899 & 2.012 & 0.678 \\
\hline WO1 & 10 & 0 & 1.924 & 2 & 1 & 4 & 2.041 & 0.255 & 0.804 \\
\hline WO2 & 11 & 0 & 2.076 & 2 & 1 & 5 & 0.927 & -0.659 & 1.382 \\
\hline
\end{tabular}


Effect of Happy 8 Workplace \& Corporate Social Responsibility on SMEs during Covid-19 135

\begin{tabular}{|c|c|c|c|c|c|c|c|c|c|}
\hline WO3 & 12 & 0 & 1.984 & 2 & 1 & 5 & 0.909 & 0.296 & 0.772 \\
\hline WO4 & 13 & 0 & 1.881 & 2 & 1 & 5 & 0.71 & 1.78 & 0.815 \\
\hline WO5 & 14 & 0 & 2.005 & 2 & 1 & 5 & 0.732 & 2.948 & 0.576 \\
\hline SSME1 & 15 & 0 & 2.195 & 2 & 1 & 5 & 0.854 & 0.018 & 0.506 \\
\hline SSME2 & 16 & 0 & 2.016 & 2 & 1 & 5 & 2.054 & 1.05 & 1.809 \\
\hline SSME3 & 17 & 0 & 2.005 & 2 & 1 & 5 & 0.724 & 0.355 & 0.336 \\
\hline SSME4 & 18 & 0 & 2.114 & 2 & 1 & 5 & 0.847 & 2.361 & 0.804 \\
\hline SSME5 & 19 & 0 & 2.168 & 2 & 1 & 5 & 0.811 & 1.445 & 0.846 \\
\hline SSME6 & 20 & 0 & 1.995 & 2 & 1 & 5 & 0.835 & -0.054 & 0.516 \\
\hline SSME7 & 21 & 0 & 1.973 & 2 & 1 & 5 & 0.788 & 0.228 & 0.516 \\
\hline
\end{tabular}

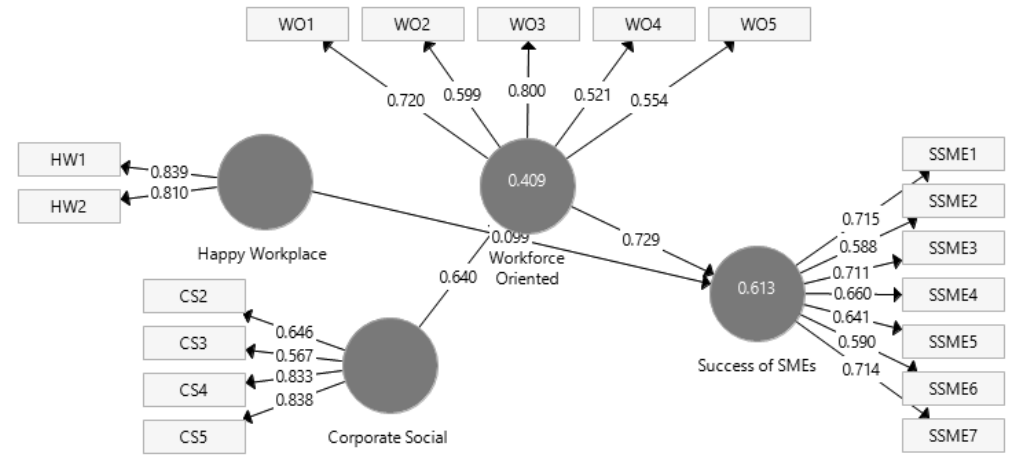

Figure 3. Measurement Model

Table 2. Factor Loadings

\begin{tabular}{|c|c|c|c|c|}
\hline & Corporate Social & Happy Workplace & Success of SMEs & Workforce Oriented \\
\hline CS2 & 0.646 & & & \\
\hline CS3 & 0.567 & & & \\
\hline CS4 & 0.833 & & & \\
\hline CS5 & 0.838 & & & \\
\hline HW1 & & 0.839 & & \\
\hline HW2 & & 0.81 & & \\
\hline SSME1 & & & 0.715 & \\
\hline SSME2 & & & 0.588 & \\
\hline SSME3 & & & 0.711 & \\
\hline SSME4 & & & 0.66 & \\
\hline SSME5 & & & 0.641 & \\
\hline SSME6 & & & 0.59 & \\
\hline
\end{tabular}


Effect of Happy 8 Workplace \& Corporate Social Responsibility on SMEs during Covid-19 136

\begin{tabular}{|c|c|c|c|c|}
\hline SSME7 & & & 0.714 & \\
\hline WO1 & & & & 0.72 \\
\hline WO2 & & & & 0.599 \\
\hline WO3 & & & & 0.8 \\
\hline WO4 & & & 0.521 \\
\hline WO5 & & & 0.554 \\
\hline
\end{tabular}

Table 3. Reliability and Convergent Validity

\begin{tabular}{|c|c|c|c|c|}
\hline & Alpha & rho_A & CR & (AVE) \\
\hline Corporate Social & 0.72 & 0.788 & 0.817 & 0.534 \\
\hline Happy Workplace & 0.753 & 0.532 & 0.809 & 0.68 \\
\hline Success of SMEs & 0.785 & 0.788 & 0.844 & 0.538 \\
\hline Workforce Oriented & 0.752 & 0.677 & 0.778 & 0.519 \\
\hline
\end{tabular}

Table 4. Cross-Loadings

\begin{tabular}{|c|c|c|c|c|}
\hline & Corporate Social & Happy Workplace & Success of SMEs & Workforce Oriented \\
\hline CS2 & 0.646 & 0.131 & 0.39 & 0.343 \\
\hline CS3 & 0.567 & 0.173 & 0.329 & 0.252 \\
\hline CS4 & 0.833 & 0.36 & 0.585 & 0.53 \\
\hline CS5 & 0.838 & 0.491 & 0.566 & 0.623 \\
\hline HW1 & 0.379 & 0.839 & 0.398 & 0.474 \\
\hline HW2 & 0.347 & 0.81 & 0.37 & 0.354 \\
\hline SSME1 & 0.488 & 0.331 & 0.715 & 0.518 \\
\hline SSME2 & 0.495 & 0.471 & 0.588 & 0.485 \\
\hline SSME3 & 0.454 & 0.171 & 0.711 & 0.547 \\
\hline SSME4 & 0.368 & 0.306 & 0.66 & 0.461 \\
\hline SSME5 & 0.389 & 0.293 & 0.641 & 0.435 \\
\hline SSME6 & 0.455 & 0.239 & 0.59 & 0.521 \\
\hline SSME7 & 0.41 & 0.348 & 0.714 & 0.607 \\
\hline WO1 & 0.62 & 0.368 & 0.512 & 0.72 \\
\hline WO2 & 0.39 & 0.339 & 0.541 & 0.599 \\
\hline WO3 & 0.442 & 0.387 & 0.643 & 0.8 \\
\hline WO4 & 0.189 & 0.258 & 0.35 & 0.521 \\
\hline WO5 & 0.316 & 0.251 & 0.422 & 0.554 \\
\hline
\end{tabular}

After clarifying through testes that the data that were collected are normal, reliable, and valid. After its hypothesis was tested that was made in the literature review. Figure 4 and Table 5 depict that $t$ values are greater than 1.96 which means that all hypotheses are accepted. 


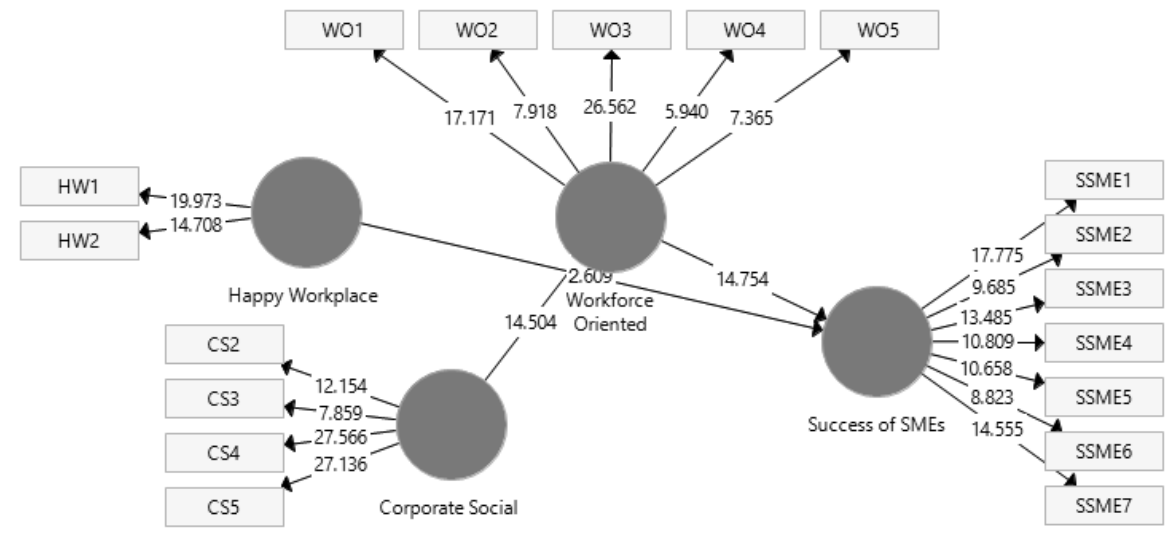

Figure 4. Structural Model

Table 5. Direct Effect Results

\begin{tabular}{|c|c|c|c|c|c|}
\hline & $\begin{array}{c}\text { Original } \\
\text { Sample } \\
(\mathrm{O}) \\
\end{array}$ & $\begin{array}{c}\text { Sample } \\
\text { Mean } \\
\text { (M) }\end{array}$ & $\begin{array}{c}\text { Standard } \\
\text { Deviation } \\
\text { (STDEV) }\end{array}$ & $\begin{array}{c}\text { T Statistics } \\
(|\mathrm{O} / \mathrm{STDEV}| \\
)\end{array}$ & $\begin{array}{c}\mathbf{P} \\
\text { Values }\end{array}$ \\
\hline $\begin{array}{l}\text { Corporate Social -> Workforce } \\
\text { Oriented }\end{array}$ & 0.64 & 0.646 & 0.044 & 14.504 & 0 \\
\hline $\begin{array}{c}\text { Happy Workplace -> Success of } \\
\text { SMEs }\end{array}$ & 0.099 & 0.101 & 0.038 & 2.609 & 0.008 \\
\hline $\begin{array}{l}\text { Workforce Oriented -> Success of } \\
\text { SMEs }\end{array}$ & 0.729 & 0.734 & 0.049 & 14.754 & 0 \\
\hline
\end{tabular}

Table 6 represents the mediation of workforce orientation between the corporate social responsibility and success of small and medium enterprises is present because $t$ value 9.924 is greater than 1.96. This mediation also showed in Figure 5.

Table 6. Indirect Effect Results

\begin{tabular}{|c|c|c|c|c|c|}
\hline & $\begin{array}{c}\text { Original } \\
\text { Sample } \\
(\mathbf{O})\end{array}$ & $\begin{array}{c}\text { Sampl } \\
\mathbf{e} \\
\text { Mean } \\
\mathbf{( M )}\end{array}$ & $\begin{array}{c}\text { Standard } \\
\text { Deviation } \\
\text { (STDEV) }\end{array}$ & $\begin{array}{c}\text { T Statistics } \\
(\text { (IO/STDEV } \\
\text { I) }\end{array}$ & $\begin{array}{c}\text { P } \\
\text { Values }\end{array}$ \\
\hline $\begin{array}{c}\text { Corporate Social -> Workforce } \\
\text { Oriented -> Success of SMEs }\end{array}$ & 0.466 & 0.474 & 0.047 & 9.924 & 0 \\
\hline
\end{tabular}




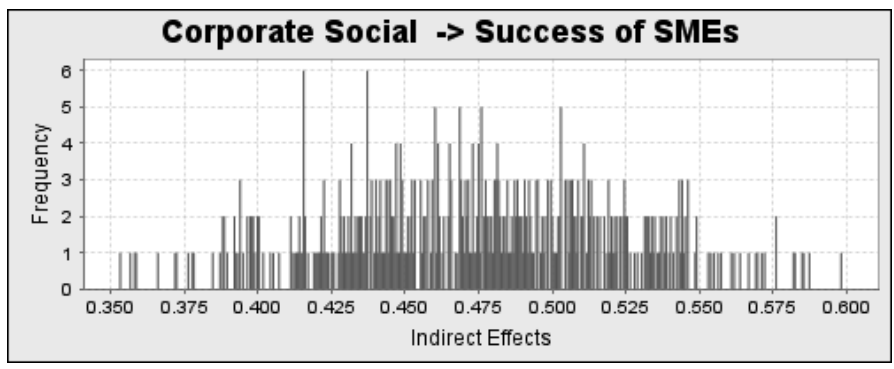

Figure 5. Indirect Effect

The impact of the Happy 8 workplace, corporate social responsibility, and workforce oriented on the success of small and medium enterprises is $61.3 \%$.

\section{DISCUSSION}

Results that generated from collected data related to variables like (Happy 8 workplace, corporate social responsibility, workforce oriented, and success of small and medium enterprises) indicate that. The Happy 8 workplace has a positive significant impact on the success of small and medium enterprises. Different previous studies also argued that happiness increases the productivity of employees in the workplace. Studies found that when employees are happier their working speed gradually increases (Kohtamäki, Parida, Patel, \& Gebauer, 2020). This Happy 8 workplace has a substantial impact on the performance of companies. This study also argued that the Happy 8 workplace increases the success of small and medium enterprises in Thailand.

Corporate social responsibility also has a positive impact on the success of small and medium enterprises and workforce orientation. Workforce orientation has a positive impact on the success of small and medium enterprises. Furthermore, workplace orientation mediates the relation between corporate social responsibility and the success of small and medium enterprises in Thailand. Corporate social responsibility means the philanthropic and societal work of an organization plays an important part in the success of corporations (Kim, Eisenberger, \& Baik, 2016). This philanthropic work related to the workforce or employee orientation also increases the success of small and medium enterprises. 


\section{CONCLUSION}

This current study also wants to explore the relationship between the Effect of Happy 8 Workplace and Corporate Social Responsibility on Success of Small and Medium Enterprises among employees working in small and medium enterprises functioned in Thailand. Happy 8 workplace simply the workplace of happiness in which you have to know the 8 questions related to happiness. Happy 8 workplace means happy and satisfied employees are working at the workplace. This happy workplace or happy workers of corporation increase the performance of the company. Another factor that contributes to higher performance is corporate social responsibility means societal and philanthropic work from organizations. Data is collected through a questionnaire via a drop-down survey method. Items related to variables taken from previous studies. The study is quantitative. Simple random sampling technique for data collection. Results that produced from collected data specify that Happy 8 workplace and corporate social responsibility have a positive significant impact on the success of small and medium enterprises. Corporate social responsibility also has a positive influence on workforce orientation and workforce orientation also intervenes in the relationship between corporate social responsibility and the success of small and medium enterprises. The current study gives recommendations to policymakers that they should focus on the Happy 8 workplace and corporate social responsibility for increasing the success of small and medium enterprises. 


\section{REFERENCES}

Crawford, J., Butler-Henderson, K., Rudolph, J., \& Glowatz, M. (2020). COVID-19: 20 Countries' Higher Education Intra-Period Digital Pedagogy Responses. Journal of Applied Teaching and Learning, 3(1), 9-28.

Dean, M., \& Spoehr, J. (2018). The fourth industrial revolution and the future of manufacturing work in Australia: Challenges and opportunities. Labour $\mathcal{E}$ Industry: A journal of the social and economic relations of work, 28(3), 166-181.

Eberhard, B., Podio, M., Alonso, A., Radovica, E., Avotina, L., Peiseniece, L., Sendon, M., Lozano, A., \& Solé-Pla, J. (2017). Smart work: The transformation of the labour market due to the fourth industrial revolution (I4.0). International Journal of Business $\mathcal{E}$ Economic Sciences Applied Research, 10(3), 47-66.

Ghislieri, C., Molino, M., \& Cortese, C. (2018). Work and organizational psychology looks at the fourth industrial revolution: How to support workers and organizations?. Frontiers in psychology, 9, 2365.

Gleason, N. (ed.). (2018). Higher education in the era of the Fourth Industrial Revolution. Singapore: Palgrave Macmillan.

Kim, K., Eisenberger, R., \& Baik, K. (2016). Perceived organizational support and affective organizational commitment: Moderating influence of perceived organizational competence. Journal of Organizational Behavior, 37(4), 558-583.

Kohtamäki, M., Parida, V., Patel, P., \& Gebauer, H. (2020). The relationship between digitalization and servitization: The role of servitization in capturing the financial potential of digitalization. Technological Forecasting and Social Change, 151, 119804.

Lee, M., Yun, J., Pyka, A., Won, D., Kodama, F., Schiuma, G., Park, H., Jeon, J., Park, K., Jung, K., Yan, M., Lee, S., \& Zhao, X. (2018). How to respond to the fourth industrial revolution, or the second information technology revolution? Dynamic new combinations between technology, market, and society through open innovation. Journal of Open Innovation: Technology, Market, and Complexity, 4(3), 21.

Nadeem, S., Alvi, A., \& Iqbal, J. (2018). Performance Indicators of E-Logistic System with mediating role of Information and Communication Technology (ICT). Journal of Applied Economics \& Business Research, 8(4), 217-228.

Oosthuizen, C. (2016). Entrepreneurial intelligence: expanding schwab's four-type intelligence proposition to meaningfully address the challenges of the fourth industrial revolution. Paper presented at the 28th Annual Conference of the Southern African Institute of Management Scientists, University of Pretoria, South Africa.

Romero, D., Stahre, J., Wuest, T., Noran, O., Bernus, P., Fast-Berglund, Å., \& Gorecky, D. (2016). Towards an operator 4.0 typology: a human-centric perspective on the fourth industrial revolution technologies. Paper presented at the International Conference on Computers and Industrial Engineering, Tianjin, China.

Selamat, A., Alias, R. A., Hikmi, S. N., Puteh, M., \& Tapsi, S. (2017). Higher education 4.0: Current status and readiness in meeting the fourth industrial revolution challenges. Redesigning Higher Education towards Industry, 4, 23-24.

Thongrawd, C., Bootpo, W., Thipha, S., \& Jermsittiparsert, K. (2019). Exploring the Nexus of Green Information Technology Capital, Environmental Corporate Social Responsibility, Environmental Performance and the Business Competitiveness of Thai Sports Industry Firms. Journal of Human Sport and Exercise, 14(5 Proc), S2127-S2141. 
Zhao, N., Attrebi, O., Ren, Y., Qiao, W., Sonustun, B., Martens, Y., Meneses, A., Li, F., Shue, F., Zheng, J., Ingelgom, A., Davis, M., Kurti, A., Knight, J., Linares, C., Chen, Y., Delenclos, M., Liu, C., Fryer, J., Asmann, Y., McLean, P., Dickson, D., Ross, O., \& Bu, G. (2020). APOE4 exacerbates a-synuclein pathology and related toxicity independent of amyloid. Science translational medicine, 12(529), eaay1809. 


\title{
Chapter 9
}

\section{Usage of IT Interventions in the Containment of Covid-19 Spread}

\author{
Ameema Mahroof
}

\begin{abstract}
This chapter focused on the digital technologies in the containment of COVID-19 spread. Digital technologies can facilitate in devising the mechanism for pandemic control in ways that manually isn't possible. The objective of this chapter is to explore the IT interventions that can be used for flattening the curve as well as to decrease its huge strain on health care. The author presented have systems that can be developed and implemented for the containment of this deadly disease i.e. T3 system, dashboards, Surveillance and compliance app, relief management system, and helpline and telemedicine unit. T3 system included patient reporting, case response, capturing traveler information, hotspot declaration, indoor surveillance, awareness and burial. Dashboard can help authorities to look at the overall situation of covid 19 and activities related to preventive and control measures to flat the curve of pandemic. Relief management system can be developed to reach the people affected by the pandemic of covid-19, this system plays their part that allows the Departments, organizations, NGOS, and Individual to donate for deserving people. Telemedicine $\mathcal{E}$ call-center can be established for the public guidelines and awareness along with treatment protocol using technologies. Author concluded that countries who have these adopted digital technologies to facilitate planning, surveillance, monitoring, testing, contact tracing, and quarantine have front runners in managing the burden of the disease as well as in flattening the curve. This chapter provides implications for the future studies such as exploring the possible factors of IT interventions during the covid-19 pandemic for developing and developed countries and strength's, weakness and limitations of each system
\end{abstract}

Keywords: Covid19, Information Technology, Reporting, Dashboard, Surveillance, Quarantine, Call Center, Telemedicine 


\section{INTRODUCTION}

This objective of this chapter is to explore the IT interventions and their roles to defeat the spread of novel corona virus and to further investigates strength's and weakness in ICT interventions for the containment of this spread. To achieve this objective, observations, online content and systems analysis is done to gain the useful insights regarding the implementation of these digital technologies for this global concern.

The episodes of this COVID-19 19 pandemics present a threat to general well-being and it's the greatest challenge we have faced since WORLD WAR II. Since its emergence the virus has spread to almost every continent and death toll is kept on increasing. Covid-19 pandemic is much more than a health crisis, it affects the countries social and economic status so badly that leaves the long-lasting impact. People are losing their jobs, organizations and traders are in loss and no one knows when the normality will return.

In these difficult and challenging situations, to defeat or decrease the impact of COVID-19 on people's health and countries economy, every country needs to devise strategies towards its response. This document focuses on the IT interventions that can be used to flatten the curve of covid-19 and thus decrease it huge strain on health care systems. (Budd, Miller, Manning et al, 2020). Since the world is trying to defeat this deadly pandemic the role of IT to increase awareness, prevention, surveillance, patient reporting, case response, and treatment for Covid-19 has become more significant and important.

\section{BACKGROUND}

Pakistan brought its IT expertise to covid-19 pandemic and laid down the basis for modernization of data consolidation and reporting methodologies that can help the authorities to devise strategies in containment of COVID-19 19.

A number of IT initiatives have been taken around the world that includes a) central dashboard to display update stats on COVID-19 19 patients, maps, awareness mechanism. (Zaman, Islam, Zaki \& Hossain, 2020). IT initiatives or interventions can be taken as one of the most effective method around the world in flattening the curve against the pandemic spread. In developing countries like Pakistan, several systems can be developed and implemented for the containment and mitigation to flatten the peak of COVID-19.

Related work:

Bajpai, Biberman \& Ye (2020), mentioned many ICT interventions for immediate relief and medical response that is a) Testing \& diagnosis, Patient centric record keeping, case response, telemedicine and enforcing quarantine and social distancing. They further stated that involving ICT in pandemic relief and prevention carries with its own set of challenges involving transparency, accountability, and privacy. Zaman, Islam, Zaki \& Hossain (2020) in their study devised the six viable opportunities to strengthen the ICT intervention. Galaz (2020) discussed in their work that how the IT can ease to provide early alerts or warnings about the pandemic which can help authorities to take necessary actions and measure for fighting it. 


\section{MAIN FOCUS OF THE CHAPTER}

The purpose of this chapter is to propose the mechanism for the containment of Covid-19 spread using the mobile applications and web portals. This topic of COVID-19 is very new and emerging and since there is no such literature available to it that's why observed and online content review approach used to suggests' the mechanism for the containment of covid-19 using ICT. Details are given below

* Trace, Track and Treat System:

* Live Dashboard

* Surveillance \& Compliance App

* Relief Management System

* Helpline and Telemedicine Unit

\section{COVID-19 TRACK, TRACE AND TREAT SYSTEM}

In times of Covid-19 crisis, accurate representation of patients is critical for monitoring the ongoing situation and making informed decisions. For this purpose, Track, Trace and Treat system can help in reporting the patients from a) Hospitals b) Quarantine Centres c) Labs.

This system will have following modules:

1. Patient reporting

2. Contact Tracing of confirmed persons

3. Capturing travellers' record \& follow-up

4. Hotspot declaration

5. Indoor Surveillance

6. Awareness about preventive measures to all public

7. Burial

\section{PATIENT REPORTING:}

Patient portal should be developed for the accurate reporting of covid-19 patients. Patient reporting used for capturing corona infected person's information which includes persons demographic, corona symptoms, Travel history, any associated comorbidity, contact history, lab and test results, patient status (Suspected and confirmed) \& outcome. This system used in all public and private hospitals of Punjab for entering record of corona infected person. Once confirmed patient have been reported in the system, the next phase of preventive measure within a containment program is to identify those persons who came in contact of that carrier. Contact Tracking can be done using the mobile application.

\section{PATIENT TRACING \& TRACKING MOBILE APP}

Mobile application will be used for tracking the patients for the purpose of monitoring and verification mechanism. All data reported on web portal either through hospitals or from airport and borders will be pushed to mobile application and this mobile application will be used by field workers to track the suspected and confirmed patients, travellers, indoor surveillance, awareness, and burial through GPS enabled android based mobile application as it captures the location. This mobile application will cover multiple Once positive cases have been definitively identified, sick individuals must be placed into social isolation to 
allow them to recover from the disease without the possibility of infecting anybody else. activities like

i) Household information

ii) Contact Tracing

iii) Preventive measures

Field team geo-tag the patient residence and workplace location of confirmed patients. This tagging will be depicting on the maps. Teams can be able to tag, map, take picture and submit digitally in real time. The taken pictures are then geo-tagged on the particular location with latitude and longitude and uploaded on the dashboard or the portal. With the help of this tagging, authorities can mark areas as hotspots and devise strategies for lockdown. This exercise enables by technology prevents further spread in the vicinity of confirmed patients.

Figure 1. Mobile App

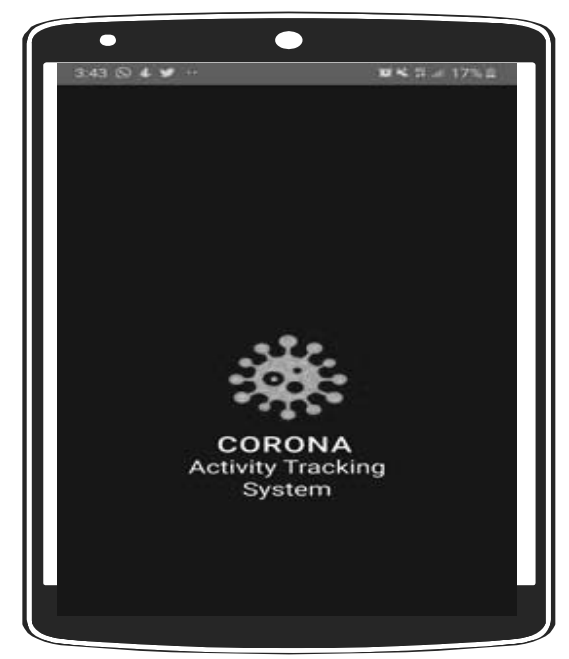

\section{TRAVELLERS}

All the persons data arriving at the airport will be captured in the system. Details of their initial screening reports and COVID-19 tests will be entered in the system. Arrivals will be tagged as "Under-Observation" in the system. All the under-observed patients will be kept under monitoring and they must quarantine for three days at their residence, if no signs or symptoms appears quarantined measures will be exempted and patient status will be closed in the system. Field teams must visit arrivals places to make sure they are quarantined. Field team install the travelers' app in the arrivals phone. Once application installed, arrival location captured and their 
boundary created in the system. If patient is out of that boundary, alert generates and SMS Alerts sent to the authorities for taking appropriate action against the arrival.

Figure 2. Traveler's Entry Flow

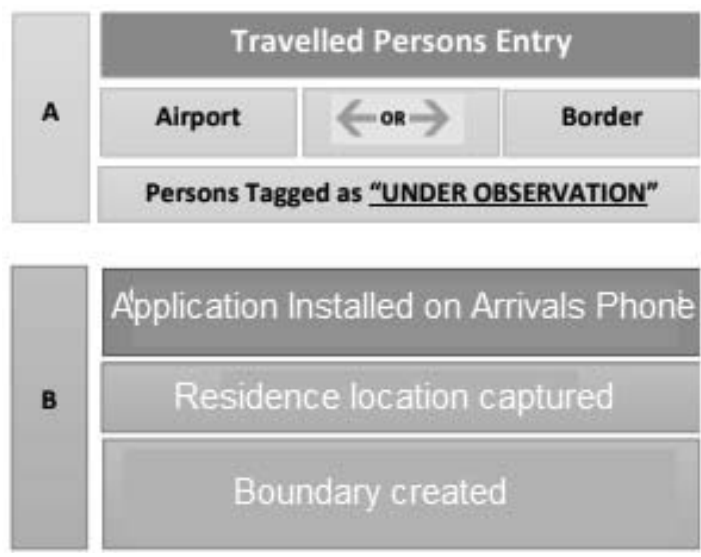

\section{IDENTIFICATION OF HOTSPOTS:}

The scope of patient tracking and tracing has increased over the last several months with their work becoming useful in identifying the hotspots areas for lockdown. Monitoring teams should equip with mobile phones through tracking \& tracking application Areas tagged or identified as hotspots based on patient reporting are introduced as hotspot regime in the system to further strengthen the surveillance and monitoring of corona

Tagged patients of all categories get plotted on maps via android based mobile application in real time as mobile application geo-tagged the location of patient. This tagging of patients helps in building clusters of patients in map and will depict as defined legends and based on these clusters' authorities and govt official can take actions and make strategies against those areas where clusters increased to restrict the movements or to seal area. The high-risk areas or sites which are known to spread covid-19 were termed hotspots and it should be agreed that these hotspots should be completely disinfect with a complete lockdown. Sampling tests should be conducted after two weeks in hotspots areas and where results are more negative should be exempted from hotspots. 
Figure 3. Location Map of Corona Patients

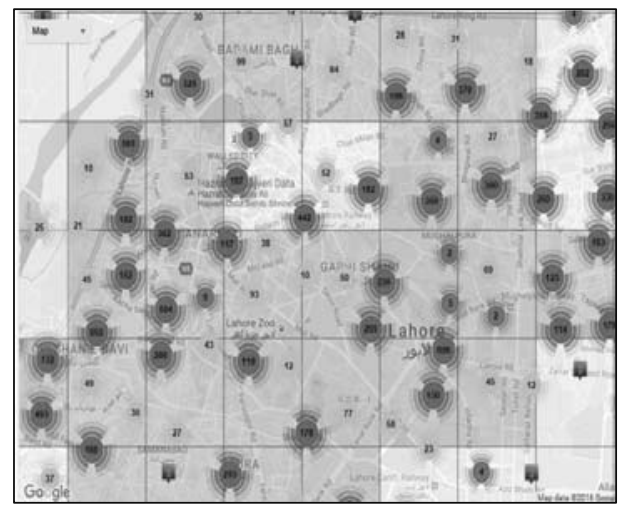

Figure 4. Hotspot area for covid patients

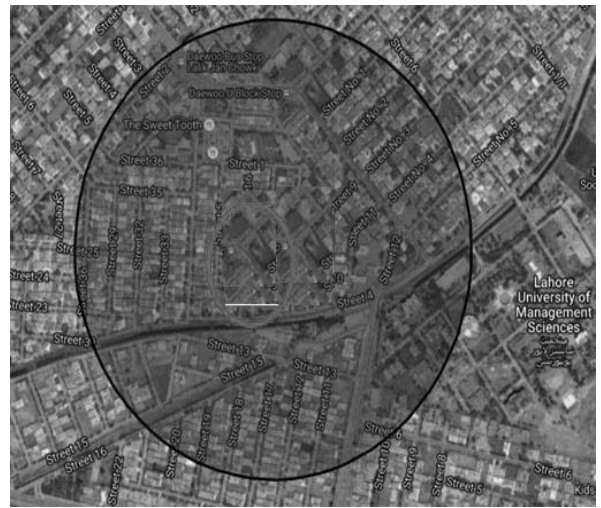

\section{QUARANTINED AT HOME STRATEGY}

Once the confirmed patient reported in the system the next step is to place those sick persons into social isolation to allow them to recover from the disease without infection other persons. This can only be done with strict empowerment of quarantined strategy with complete facilities. For making the quarantined at home strategy successful indoor surveillance needs to be done as well. Teams tasks with door to door surveillance and inspects the facilities house have for a quarantined measure. After the inspection the team will tag houses as satisfactory for quarantined or non-satisfactory for quarantined in the mobile application. Any patient reporting from the house where quarantined measure is not satisfactory, that person will be quarantined in the govt provided quarantined centre. Tagged houses (Satisfactory or not satisfactory) will show in a map this geo-tagging and mapping enables identification of areas which are not visited my any monitoring team.

\section{LIVE DASHBOARD:}

Live dashboard is developed for real-time patient reporting and monitoring overall COVID-19 situation across Punjab. The dashboard shows heat maps based on field activities that identify clusters for Lockdown/Chlorination /Disinfection. 
Figure 5. Covid-19 Dashboard

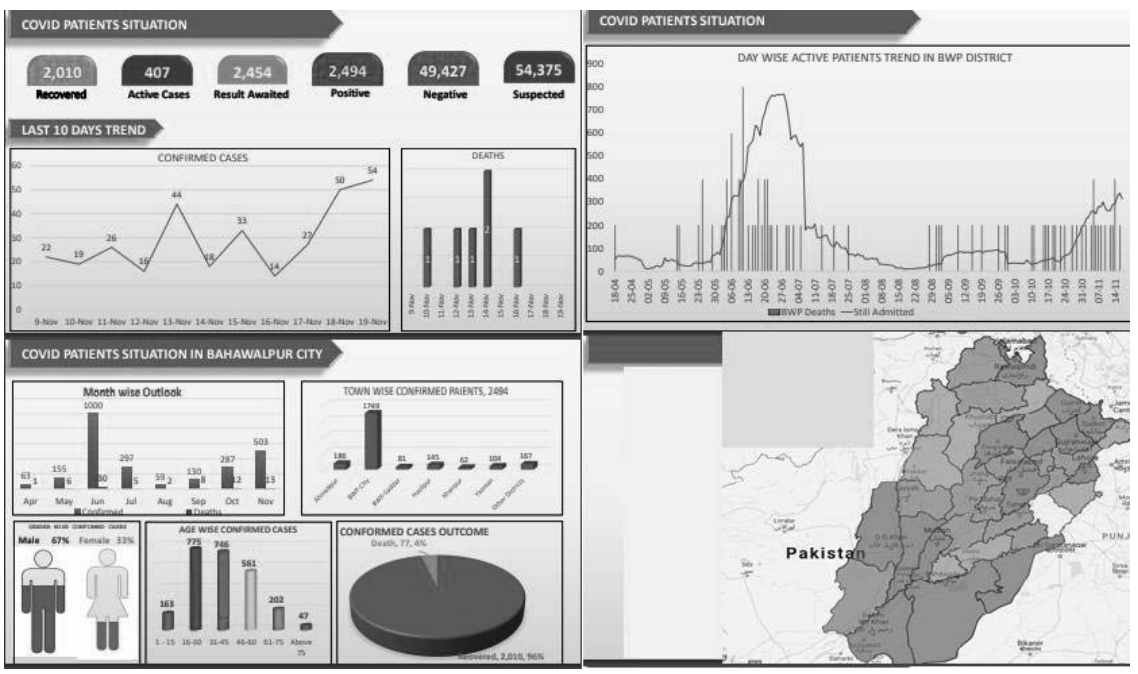

\section{COVID-19 SURVEILLANCE \& MONITORING APP}

Mobile application also developed for monitoring \& surveillance of Marketplaces \& Masjid for compliance to SOPs during COVID-19 pandemic.

Figure 6. Map of Covid-19 Surveillance Activities
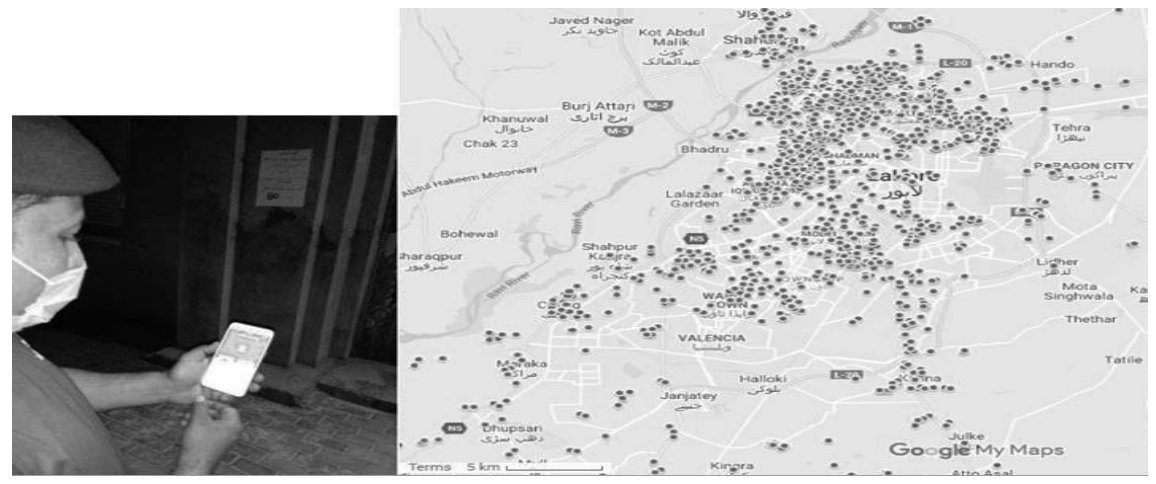


\section{DISBURSEMENT MANAGEMENT SYSTEM}

To reach the people affected by the pandemic of covid-19, this system plays their part that allows the Departments, organizations, NGOS, and Individual to

- Donate for deserving people

- Keep track of all disbursements

- Delivery to end user

- Verification of deserving people through other systems

This system will be used to provide relief in form of ration and medical equipment's to the deserving and needy persons.

Figure 7. Disbursement Management System
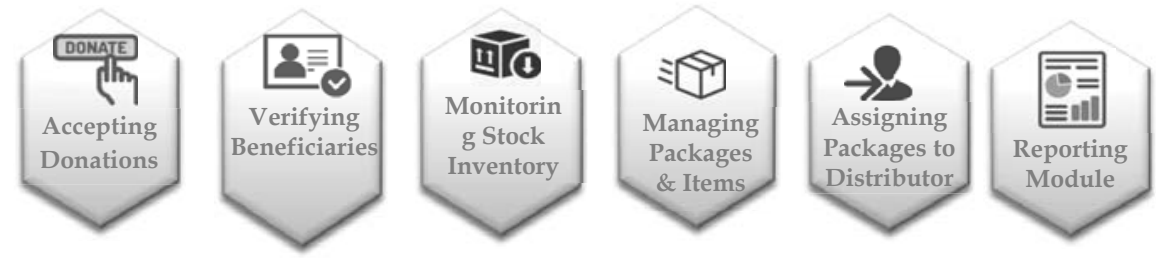

\section{ESTABLISHMENT OF A CALL CENTRE AND A TELEMEDICINE:}

The biggest challenge faced by any hospital during a pandemic is the number of daily cases within a shorter amount of time. Surge of critical cases beyond their capacity to treat or manage within this hospital is the biggest threat.

In that scenarios, telemedicine can play an important role by reducing the number of daily visitors in the hospital. Patients who do not have major or threating symptoms have been requested to remain home in order to save the space for the critical cases. Going to the hospital can also pose a significant threat of exposure to covid-19. Call center needs to be established almost immediately and toll-free number along with awareness messages should widely promulgated for the general public. The call centers should be staffed with Medical Officers who readily offered counselling, advice and propagated best practices to promote overall wellbeing. These health officers also refer the patient to hospitals or advice the patient with minor symptoms to stay at home.

To check the daily call log and complaint, dashboard will be developed. Citizens can log complaints regarding SOPs violation, the complaint is assigned to the responsible department for resolution. 
Figure 8. Telemedicine Dashboard

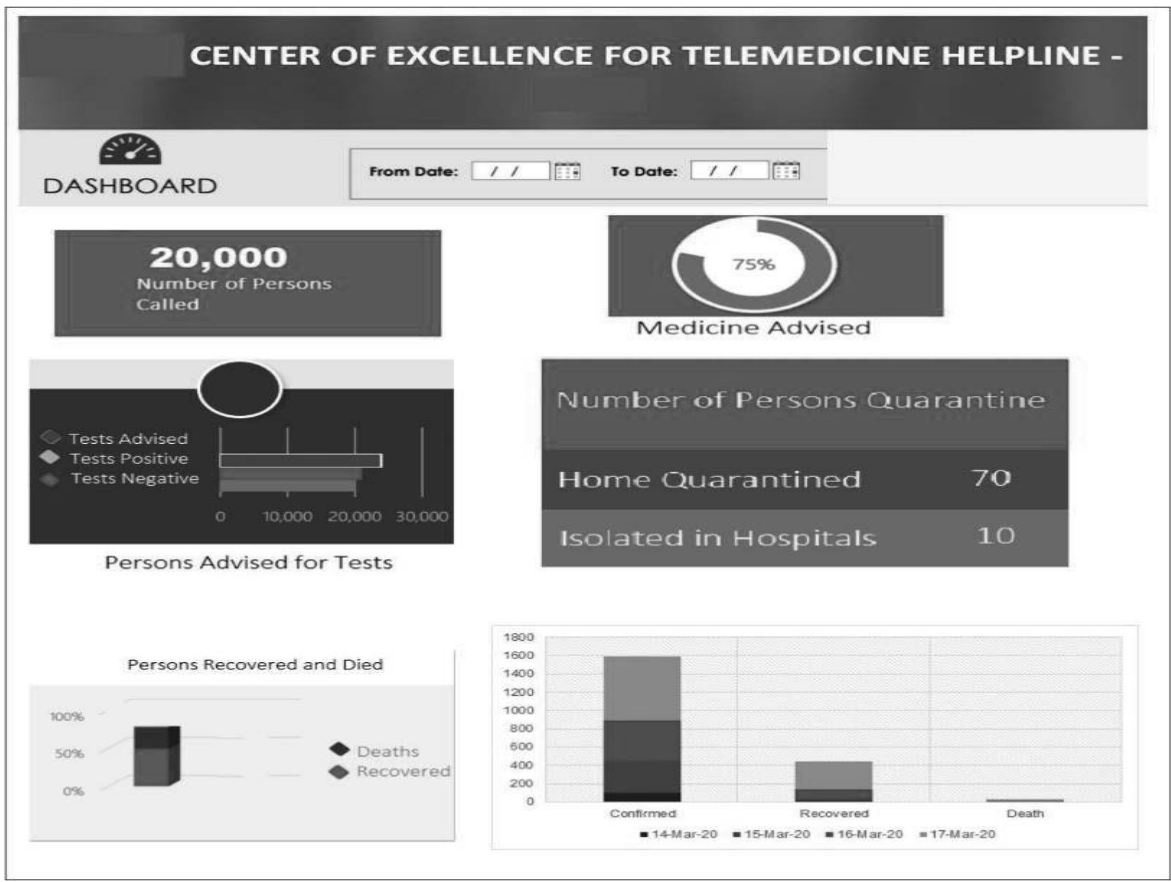

\section{CONCLUSION}

Covid-19 cases have grown rapidly in a growing number of countries, triggering bold policy responses. This chapter aimed to explore the digital technologies that can be used for the containment of covid-19 spread. in this race of flattening the curve, countries who have adopted digital technologies to facilitate planning, surveillance, monitoring, testing, contact tracing, and quarantine have front runners in managing the burden of the disease as well as in flattening the curve.

The present chapter provides an insight regarding the ICT interventions by explaining one by one the type of IT solutions that can be develop and deploy during the Covid-19 pandemic to help the health sector in controlling and decreasing the death tolls. The outcome of these systems will contribute to the IT experts, health authorities, policy makers, government officials and individuals to aware about IT tools and technologies and their role in the containment of this pandemic.

If all these systems developed and implemented in a proper way, flattening the curve for CoVID19 wouldn't be so difficult. Authorities and Government officials can take decisions and devise 
strategies keeping in view the dashboard stats, hotspots areas, SOPs violation percentage, complaint log and resolution.

Persons reporting (Hospitals, Labs) and their case response within 24 hours can help in embossing restrictions for self-quarantined measure to prevent the spread. Contact tracing can help identifying the persons that contracted with a carrier person and thus advised them to for isolation can help in the containment activities. Tagging and reporting of patients will build areawise clusters in map which helps the authorities to take a decision for lock down or sealing the area. Capturing traveler's data, tracing their location via mobile device can prevent the spread of covid-19 to others. To check the compliance of SOPs in markets, lockdown areas, schools, offices can be done using surveillance and monitoring mobile app. Telemedicine can help to manage the patient load by advising and counselling patients via telemedicine or call. Dashboard will update you about the COVID-19 scenario, it will give your insight regarding patient's positive cases, hospitalizations and deaths. It will help you track and monitor hotspots with ease. Without it, no one can able to tell either its curve flattening or increasing.

\section{Issues, Controversies, Problems}

There are many advantages for adopting the ICT interventions but despite having various strengths it has some weaknesses as well. Some of them are:

1. Digital technologies cannot operate alone it has to be implemented fully in health sector. For its implementation, there should be bandwidth of resources, hardware and infrastructure. All these may overlook but without these, ICT interventions is a complete failure.

2. Authenticity of data is a major challenge. Wrong entry of data and not proper use of the systems for patient reporting is the issues.

3. Costs is a biggest issue developing countries like Pakistan are facing during this covid19 pandemic. And reserving funds for the ICT interventions isn't possible when there are so many other important problems.

\section{SOLUTIONS AND RECOMMENDATIONS}

Following can be a solution to the issues.

1. Funding agencies, donors can be contacted for the funds so that appropriate mechanism can be provided for this.

2. There must a proper training of end users and then monitoring of them to avoid from data loopholes.

3. For the implementation, proper rollout plan should be finalized with the input of all relevant stakeholders.

\section{FUTURE RESEARCH DIRECTIONS}

This chapter provides implications for the future studies such as

a) exploring the possible factors of IT interventions during the covid-19 pandemic for developing and developed countries.

b) Strength's, weakness and limitations of each system 


\section{REFERENCES}

Budd, J., Miller, B.S., Manning, E.M. et al. Digital technologies in the public-health response to COVID-19. Nat Med 26, 1183-1192 https:// doi.org/10.1038/s41591-020-1011-4

Bajpai, N., Biberman, J., \& Ye, Y. (2020). ICTs and Public Health in the Context of a Pandemic.

Galaz V. Pandemic 2.0 (2009. Can information technology help save the planet? Environment Science and Policy for Sustainable Development, 51,20-28.

Zaman, A., Islam, M.N., Zaki, T \& Hossain, M.S (2020). ICT intervention in the containment of the pandemic spread of COVID-19: An exploratory study. 


\section{Emerging Trends and Strategies for Industry 4.0: During and Beyond Covid-1}

\section{CHAPTERS KEY TERMS AND DEFINITIONS}

\section{Chapter 1}

Collective Resilience: the ability of teams to regard stress, disorders and uncertainty in a degree that allow them to cope with daily challenges, develop ambitions and feel comfortable to interact with other people.

Fluent Change: accepting that being organizational agile imply learning to continuously adapt to complex, ceaseless changes.

Organizational Agility Enabler: contributing factor to developing agility in organizational context, as an ability to continuously sense changes and decide for fast and adequate respond.

Strategic Agility: an intentional, unequivocal decision to create, foster and develop agility in organizational context.

\section{Chapter 2}

Covid 19: New Coronavirus Disease (Covid-19) is a virus first identified on January 13, 2020, as a result of research conducted in a group of patients who developed respiratory symptoms (fever, cough, shortness of breath) in late December in Wuhan Province of China. The outbreak was initially detected in the seafood and those been in the animal market in the area. Later, by spreading from person to person, it spread to other cities in Hubei province, especially Wuhan, and other provinces of the People's Republic of China and other world countries. Coronaviruses are a large family of viruses that can cause disease in animals or humans. In humans, several coronaviruses are known to cause respiratory infections, ranging from the common cold to more severe diseases such as Middle East Respiratory Syndrome (MERS) and Severe Acute Respiratory Syndrome (SARS). The SAR-CoV-2 virus causes new Coronavirus disease (T.C. Sağlık Bakanlığı, 2020).

Social Service: Helping individuals who encounter challenges in accessing social services for various reasons through social welfare practices. It includes protective measures to improve people's living standards to lead a life worthy of human dignity. It consists of services performed in order to adapt economically and socially needy segments to their social environment (Taşç1, 2008: 66).

Social Assistance: It is the economic aid that the state gives to its citizens in need. Social assistance financed by taxes is generally given to people or families whose income is below a certain level. 
The amount of social assistance may differ depending on the economic conditions of the countries (Aca, Özdemir ve Alper, 2018).

Printed Press: The amount of social assistance may differ depending on the economic conditions of the countries (TDK, 2020).

\section{Chapter 3}

Retailing: It is the business of providing the transfer of goods or services through a business between the producer and the consumer.

Strategic Manager: Managers who are responsible for how best to achieve the growth targets with minimum risk for the growth of an enterprise.

Digitization: It is the computerization of systems and jobs to be easier and more accessible.

Artificial Intelligence: These are programs, algorithms, systems or machines that are developed by humans but can make independent decisions and put the decision into practice.

Internet of Things: By connecting smart devices via the internet, it is to ensure that the data is controlled and the application process is carried out as desired.

Virtual Reality: It is a set of concepts and tools that try to make users feel as if they are in a different place from their environment and as if they are in a virtual universe.

Office Automation: It is the use of computer technology in an enterprise, in the preparation and processing of information and documents, information exchange between employees, and coordination of work.

\section{Chapter 4}

COVID-19: It an infectious disease caused by a virus that is severe and can be fatal. To prevent the spread of the virus, restrictions on work, study and travel have been introduced in many countries

Work-life Balance: It means the subjective perception of balancing personal and professional responsibilities 
Remote Work: It concerns the performance of professional duties away from the workplace (usually from home)

Well-being: It is the subjectively perceived state of fulfilment of all the individual's needs

Human resources management: It is a set of practices strategically oriented towards enhancing employees' performance and achieving organizational goals

\section{Chapter 5}

Emotion Regulation Skills-Abilities Model (ERSA): Is a single framework of five processes, three primary skills-abilities and secondary skills for effectively regulating another person's emotions. Skills-abilities overlap meeting to form congruency when an extrinsic regulator has high proficiency when regulating other's emotions. The model is an interpersonal extrinsic regulator skills-abilities and development model. The extrinsic regulator reacts to support seeker and demonstrate skills and behaviors associated with effectiveness for emotional regulation of others. The model identifies when there is a lack of skill this disincentives engagement and when there are skills-abilities as identified in the model this incentivizes engagement.

Theory of the ERSA: Is that personal agencies of emotional intelligence ability, emotion regulation of others-efficacy and emotion regulation are explanatory for why a regulator of other's emotion are so effective at interpersonal emotion regulation regardless of emotional regulatory strategies selection. Successful regulation of other's emotion are based on high-levels of proficiencies with emotional intelligence as an ability, self-confidence to effectively regulate other person's emotion, and emotion regulation ability are competencies for interpersonal emotion regulation.

Emotion Regulation of Others-Efficacy: A domain specific efficacy developed through the tenants of self-efficacy is a belief and self confidence in one's own ability at being successful at their efforts to regulate another person's emotions or experiences or event episode causing the person being regulated stress.

Interpersonal Extrinsic Regulator: Are intentional and deliberate about their goal for regulating another person's emotion and their efforts attempt to lead towards a desirable emotional state of change or a new emotional trajectory for the regulated person.

Extrinsic Regulator Emotional Intelligence Ability: A unique set of individual skills-abilities relating to being able to interpret another person's behaviors, actions, emotions, needs, and their own emotions for the explicit purpose of applying and implementing with accuracy understood 
knowledge to the emotional regulatory process of regulating another person's emotional change to what is desirable.

Work-Related Interpersonal Emotion Regulation: Is the non-casual and formal process of interpersonal emotion regulation linking the extrinsic regulator and support seeker by hierarchical position or role. The extrinsic regulator is motivated based upon their role and their intentions for the regulatory process of regulating another person's emotion, an extrinsic regulator is highly influenced towards attempting to change the employee current work performance

\section{Chapter 6}

COVID-19 pandemia: The New Coronavirus Disease (COVID-19) is a virüs that was first emerged in Wuhan Province in December 2019 and first identiefied on January 13, 2020 as a result of research conducted in a group of patients who developed respiratory symptoms (fever, cough, shortness of breath).

Financial Contagion: Financial contagion is a situation in which a shock initially impacting only a few financial institutions spills over the rest of the financial system and the economy, afterwards infecting the financial systems and other economies.

Real Economy: Real economy represents all real or non-financial components of an economy.

Stock Market: Stock market is the collectionof buyers and sellers representing ownership claims on business and exchange stocks.

Multivariate GARCH models: Multivariate GARCH models are financial econometric models allow to better decision tools in many areas such as asset pricing, risk management etc.

\section{Chapter 7}

Covid-19: It is an infectious disease that belongs to coronavirus family, affect human and animals.

Leadership: The role of different personalities who have some decision making power regarding educational initiatives.

Management: The innovative and efficient strategies that can be taken by the leaders for addressing the problems arising from this new situation. 
Planning: Any written and contextual based document that have some future forecasting in a more effective way.

Organizing: Supervise the people's behavior and practices in any well-defined capacity.

Leading: It refers to guidance and facilitation to the people from the qualified expert leader.

\section{Chapter 8}

Corporate Social Responsibility: A type of business self-regulation with the aim of being socially accountable.

Happy 8 Workplace: A concept of organizational development which creating happiness for personnel in 8 areas, happy body, happy heart, happy relax, happy brain, happy soul, happy money, happy family, and happy society.

Small and Medium Enterprises: Enterprises with employees fewer than 200 persons, and with fixed capital, excluding lands and properties, not exceeding THB 200 million.

Workforce Oriented SMEs: SMEs who place great importance on taking care of their employees.

\section{Chapter 9}

ICT Intervention: ICT based intervention means finding a solution for the containment of COVID-19, that may involve a development, deployment and implementation of any system.

Hotspots: Hotspots are the areas or zones from where a lot of covid-19 patient reported or places that are at risk for spreading covid-19 infection.

Quarantine: Quarantine means isolating the activities of a person for a temporary period of time as advised by the health officials.

COVID Dashboard: It's a information management system that visually track and analyze all KPI of COVID patient for effective decision making.

Surveillance: In this chapter, surveillance is the series of activities that carried out for identifying the source of disease or for the containment of that disease. 
